\begin{abstract}
UNIVERSIDADE DE SÃO PAULO
ESCOLA DE ENGENHARIA DE SÃO CARLOS

DEPARTAMENTO DE ENGENHARIA HIDRÁULICA E SANEAMENTO
\end{abstract}

PAULO MARCOS FARIA MACIEL

Remoção de Giardia spp. e Cryptosporidium spp. em Águas de Abastecimento com Turbidez Elevada Utilizando Cloreto de Polialumínio: Estudo em Escala de Bancada e Desafios Analíticos

VERSÃO CORRIGIDA

São Carlos 



\title{
Remoção de Giardia spp. e Cryptosporidium spp. em Águas de Abastecimento com Turbidez Elevada Utilizando Cloreto de Polialumínio: Estudo em Escala de Bancada e Desafios Analíticos
}

\author{
Dissertação apresentada à Escola de Engenharia de \\ São Carlos da Universidade de São Paulo, como \\ parte dos requisitos para a obtenção do título de \\ Mestre em Ciências: Engenharia Hidráulica e \\ Saneamento \\ ORIENTADORA: Prof ${ }^{a} \operatorname{Dr}^{\mathrm{a}}$ Lyda Patricia Sabogal Paz
}

São Carlos 
AUTORIZO A REPRODUÇÃO TOTAL OU PARCIAL DESTE TRABALHO, POR QUALQUER MEIO CONVENCIONAL OU ELETRÔNICO, PARA FINS DE ESTUDO E PESQUISA, DESDE QUE CITADA A FONTE.

Maciel, Paulo Marcos Faria

M113r Remoção de Giardia spp. e Cryptosporidium spp. em Águas de Abastecimento com Turbidez Elevada Utilizando Cloreto de Polialumínio: Estudo em Escala de Bancada e Desafios Analíticos / Paulo Marcos Faria Maciel; orientadora Lyda Patricia Sabogal Paz. São Carlos, 2014.

Dissertação (Mestrado) - Programa de Pós-Graduação e Área de Concentração em Hidráulica e Saneamento -Escola de Engenharia de São Carlos da Universidade de São Paulo, 2014.

1. Cryptosporidium. 2. Giardia. 3. Jarteste. 4. Policloreto de Alumínio. 5. Separação Imunomagnética. 6. Tratamento de Água. I. Título. 


\section{FOLHA DE JULGAMENTO}

Candidato: Engenheiro PAULO MARCOS FARIA MACIEL.

Título da dissertação: "Remoção de giardia spp. e cryptosporidium spp. em águas de abastecimento com turbidez elevada utilizando cloreto de polialumínio: estudo em escala de bancada".

Data da defesa: $22 / 08 / 2014$

\section{Comissão Julgadora:}

Profa. Dra. Lyda Patrícia Sabogal Paz (Orientadora)

(Escola de Engenharia de São Carlos/EESC)

Profa. Dra. Regina Maura Bueno Franco

(Universidade Estadual de Campinas/UNICAMP)

Prof. Dr. Rodrigo Braga Moruzzi

(Universidade Estadual Paulista "Júlio de Mesquita Filho"/UNESP- Rio Claro)
Resultado:
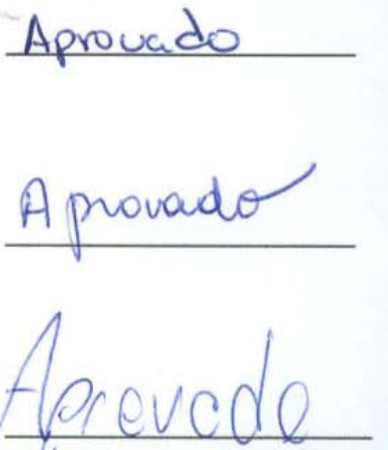

Coordenadora do Programa de Pós-Graduação em Engenharia Hidráulica e Saneamento:

Profa. Associada Maria Bernadete A. Varesche Silva

Presidente da Comissão de Pós-Graduação:

Prof. Associado Paulo César Lima Segantine 
Dedico este trabalho aos meus pai, "Zizinho" e Lúcia Pelo amor e dedicação incondiciona 


\section{AGRADECIMENTOS}

Tenho imensa gratidão à Deus, pelo caminho bonito que meus passos têm me proporcionado.

Este trabalho é fruto da colaboração de algumas pessoas que fizeram com que minha mudança para cidade de São Carlos fosse uma das grandes decisões acertadas de minha vida.

Inicialmente, agradeço a minha orientadora, Profa. Lyda, por inúmeros motivos desde o início da orientação. Sempre se mostrou disponível, foi uma grande incentivadora do meu potencial como pesquisador, apresentou sensibilidade nos momentos mais críticos do trabalho, e, sem dúvida, é uma das minhas principais referências de dedicação e ética no trabalho.

Agradeço à CNPQ, pela bolsa; à FAPESP, pelo financiamento do projeto temático “Contaminação ambiental pelos protozoários Giardia spp. e Cryptosporidium spp. e por Ascaris suum: desafios de detecção, remoção e inativação das formas infectantes".

Algumas pessoas foram essenciais para que o trabalho se desenvolvesse. Conheci no LATAR pessoas talentosas e dedicadas. Agradeço à Teresa, pela atenção, disponibilidade e paciência; ao Guilherme, grande amigo e colaborador deste trabalho em diversas etapas, sem a ajuda do qual seria muito mais difícil; ao Gabriel, sempre atento às "soluções de engenharia" para os trabalhos do laboratório; à Andressa, amiga bióloga sempre aberta à esclarecimentos e incentivadora da pesquisa; à Gabriela, amiga companheira nas análises de protozoários.

Agradeço à Profa. Regina Maura e ao biólogo Nilson, por me proporcionarem o treinamento para análise de protozoários, além da pronta disponibilidade para o esclarecimento de dúvidas.

Agradecimento especial ao Prof. Raphael Medeiros, à época doutorando do LATAR, quem me proporcionou os primeiros contatos com as análises de protozoários.

Agradeço à Dra. Luciana Urbano, pelas valiosas dicas por e-mail e telefone.

Agradeço os técnicos do Laboratório de Saneamento, Paulo e Júlio, pelo apoio no uso da estrutura do laboratório e pelas análises de metais.

Aos professores Luiz Daniel, pela autorização do uso da estrutura das análises microbiológicas, e Marco Reali, por autorizar realização da minha pesquisa no LATAR. 
Agradeço: às secretárias da pós-graduação, Sá e Priscila, pela atenção; à Rose, pela amizade e excelente humor; às servidoras da Contabilidade, Flávia e Fernanda, pelas ajudas;

Aos amigos incentivadores da reta final do trabalho: Tiago(Cebola), Juliana e meu irmão Cristiano, que ajudaram com as imagens; Matheus, companheiro das escritas da madrugada, junto com o Cebola; Carla, sempre disponível para sugestões e grande incentivadora.

Aos moradores e antigos moradores da república XB, minha segunda casa em São Carlos: Beldade, Quixeramobim, Monstro e Nego.

Às boas amizades que conquistei em São Carlos: Seu Jorge, Fred, Osvaldo, Dico, Bobo, André, Zé, Carol, Jairo, Karen, Laís, Camila, Fernanda, Ana Paula, Araceli, Tácyo, Bidjei, Vitória, Char, Inaê, Anne, Priscila, Marcão, Narumi e todos os outros que eu conheci.

Aos "velhos amigos" de Viçosa: Mateus, Curió, Dennis, Elias e Bernardo; que mantêm o laço, apesar da distância. Aos demais membros da turma de graduação EAB2007, que se esforça em manter unida.

Agradecimentos finais e talvez mais importante aos familiares:

Agradeço aos meus avós, vovô Octacílio e vovó Lira, incentivadores em todos os sentidos. À todos os tios e tias: foram valiosas as conversas e conselhos que recebi, em especial a Tia Marília, pelo carinho, apoio e preocupação constante; expando o agradecimento aos outros tios: José Mauro, Clara, Paulinho, Lenir, Beto, Nelson, Cida, Rita, Paulo.

À minha vó Fia (em memória), pessoa pura que vou lembrar sempre. Ao primo prof. Anízio, talvez o meu maior exemplo de que esforços são ações recompensadoras. Agradeço a todos os primos e primas, pelas amizades, é um pecado não citá-los nominalmente, mas sabem a importância que têm sempre.

Finalmente: agradeço aos meus familiares, que mesmo de longe buscaram sempre ajudar de todas as formas possíveis. Minha mãe, trabalhadora incansável, e meu pai, insistente constate com o bem estar dos filhos, pessoas que merecem o que a vida puder oferecer de melhor. Também ao meu irmão, Cristiano, exemplo de dedicação e conselheiro importante, em momentos pontuais. 
"O correr da vida embrulha tudo, a vida é assim: esquenta e esfria, aperta e daí afrouxa, sossega e depois desinquieta. O que ela quer da gente é coragem. 


\section{RESUMO}

MACIEL, P. M. F. (2014). Remoção de Giardia spp. e Cryptosporidium spp. em Águas de Abastecimento com Turbidez Elevada Utilizando Cloreto de Polialumínio: Estudo em Escala de Bancada e Desafios Analíticos. Dissertação (Mestrado).163f. Escola de Engenharia de São Carlos, Universidade de São Paulo, São Carlos, 2014.

O objetivo deste trabalho foi avaliar o desempenho da remoção de cistos de Giardia spp. e oocistos de Cryptosporidium parvum, em águas de abastecimento com turbidez elevada, em experimentos em escala de bancada (coagulação, floculação, decantação e filtração). Para tanto, empregou-se o coagulante cloreto de polialumínio PAC. O método de filtração em membranas foi adotado para a concentração de protozoários, seguido ou não da etapa de purificação por separação imunomagnética IMS. Os métodos foram avaliados em experimentos de controle de qualidade analítica e o método sem IMS apresentou as seguintes porcentagens de recuperação, $80 \% \pm 16,32 \%$ para cistos de Giardia spp. e 5\% $\pm 10,00 \%$ para oocistos de C. parvum. O método com IMS apresentou 31,5\% $\pm 7,55 \%$ de recuperação para cistos de Giardia spp. e $5,75 \% \pm 3,20 \%$ de recuperação para oocistos de C. parvum. Os experimentos demonstraram que não houve melhora na remoção de ambos os protozoários na condição de maior dosagem de coagulante $\left(65 \mathrm{mg} \cdot \mathrm{L}^{-1}\right.$ de PAC e $\left.\mathrm{pH} 7,29\right)$. A condição de menor dosagem de coagulante $\left(25 \mathrm{mg} \cdot \mathrm{L}^{-1}\right.$ de $\mathrm{PAC}$ e $\mathrm{pH}$ 6,76) apresentou um desempenho melhor, ao contrário de uma expectativa de que a maior dosagem de coagulante pudesse favorecer a remoção destes microrganismos. A condição de menor dosagem apresentou, na água filtrada, 50 e 75\% de ausência de identificação de cistos de Giardia e oocistos de C. parvum, respectivamente. A condição de maior dosagem apresentou (oo)cistos na água filtrada de todas amostras analisadas. Estes resultados indicam a importância do controle da coagulação na remoção de protozoários.

Palavras-chave:. Cryptosporidium spp.; C. parvum; Giardia spp.; cloreto de polialumínio - PAC; separação imunomagnética - IMS; jarteste; tratamento de água 


\begin{abstract}
MACIEL, P. M. F. (2014). Giardia spp. Cysts and Cryptosporidium spp. Oocysts Removal in High Turbid Drinking Water Using Polyaluminum Chloride: A Bench Scale Study and Analytical Challenges. Dissertação (Mestrado).163f. Escola de Engenharia de São Carlos, Universidade de São Paulo, São Carlos, 2014.
\end{abstract}

The aim of this study was to evaluate the performance of Giardia spp. cysts and Cryptosporidium parvum oocysts removal in a bench scale experiment. The coagulant polyaluminium chloride - $\mathrm{PACl}$ was used in this research. The protozoa concentration tests were performed by applying the Membrane Filtration method, with and without Immunomagnetic Separation assay-IMS. The methods were evaluated using control experiments and the method without IMS had the following percentage recovery, $80 \% \pm$ $16.32 \%$ and $5 \% \pm 10.00 \%$ for Giardia cysts and C. parvum oocysts, respectively. The method with IMS presented $31.5 \% \pm 7.55 \%$ and $5.75 \% \pm 3.20 \%$ of percentage recovery for Giardia cysts and C. parvum oocysts, respectively. Bench scale experimental results have clearly shown that there was no improvement in protozoa removal using the superior dosage of coagulant. The inferior dosage condition $\left(25 \mathrm{mg} \cdot \mathrm{L}^{-1}\right.$ of $\mathrm{PACl}$ and $\mathrm{pH}$ $6,76)$ performed better, which was contrary to what was expected in which a superior dosage of coagulant could favour when removing microorganisms. The inferior dosage condition presented $50 \%$ and $75 \%$ of absence of Giardia cysts and C. parvum oocysts in the final water, respectively. The second coagulation condition (65 mg.L-1of PACl and $\mathrm{pH} 7,29$ ) presented protozoa (oo)cysts in the final water of all the samples examined. These results indicate the importance of coagulation control in protozoa removal.

Keywords: Bench scale, Cryptosporidium spp.; C. parvum; Drinking water treatment; Giardia spp.; Immunomagnetic Separation - IMS; Polyaluminum Chloride - PACl 


\section{LISTA DE FIGURAS}

Figura 4.1 - a) Lavagem ascendente da areia com auxílio de uma seringa para promover a estratificação do meio filtrante. b) Dispositivo de sustentação para a lavagem descendente do meio filtrante na coluna de filtração.

Figura 4.2- Esquema simplificado do procedimento de concentração de (oo)cistos de protozoários aplicado a amostras de água

Figura 4.3- Itens utilizados na etapa de filtração em membranas para o procedimento de concentração de protozoários; a) bomba vácuo pressão e conjunto porta-filtro; b) Membrana Millipore ${ }^{\circledR}$ com diâmetro de $47 \mathrm{~mm}$ e porosidade nominal de $3 \mu \mathrm{m}$.

Figura 4.4 - Pellet resultante da centrifugação do líquido da raspagem de membranas, no procedimento de concentração de protozoários, de diferentes amostras. a) lodo; b) água decantada; c) água filtrada

Figura 4.5- Ressuspensão do sedimento da centrifugação no tubo de centrífuga, no procedimento de concentração de protozoários, por aparelho Vórtex.

Figura 4.6- Disposição de alíquotas do sedimento final da segunda centrifugação em poços de lâminas do kit Merifluor ${ }^{\circledR}$ a) disposição de alíquota do sedimento de água filtrada em um poço de lâmina do kit Merifluor ${ }^{\circledR}$; b) cinco alíquotas de sedimento final de água bruta e uma alíquota de água filtrada em poços de lâminas do kit Merifluor ${ }^{\circledR}$

Figura 4.7- Esquema simplificado das etapas do procedimento de IMS

Figura 4.8- Acessórios, equipamentos e ações da etapa de purificação por IMS.

Figura 4.9- Poços com alíquotas de sedimento de água bruta, sem purificação por IMS, completamente secas e aptas para etapa de preparação de lâminas para microscopia .72

Figura 4.10- Lâminas do kit Merifluor ${ }^{\circledR}$ abrigadas em câmaras úmidas e escuras, antes de receber o tratamento com os reagentes de detecção do kit.

Figura 4.11- Esquema detalhado das tarefas envolvidas na realização dos ensaios de tratabilidade, com inoculação de protozoários, em escala de bancada.

Figura 4.12- Oocistos de C. parvum agregados, presentes nas suspensão comercialmente adquirida, após meses de armazenamento (aum: 400x).

Figura 4.13- a) Retirada de amostra para leitura de $\mathrm{pH}$ e Potencial Zeta no fim da mistura rápida; b) início da formação de flocos no ensaio em jarteste; c) lavagem descendente dos FLAs com água deionizada entre a floculação e decantação

Figura 4.14- a) Coleta da água efluente dos FLAs por Erlenmeyers de 2 litros; b) detalhe de Erlenmeyer recebendo a água efluente dos FLAs c) Jarro após encaminhamento da água para os FLAs, água decantada abaixo do furo; d) coleta da água decantada, acima do lodo ...... 80 Figura 5.1- Pensamento sistêmico aplicado ao problema da transmissão da giardiose e criptosporidiose 
Figura 5.2- Diagramas de coagulação utilizando PAC, para uma água de estudo com turbidez em torno de $100 \mathrm{uT}$, expresso em termos de porcentagem de remoção de turbidez, para as seguintes condições: $\mathrm{G}_{\mathrm{mr}}=1000 \mathrm{~s}^{-1}, \mathrm{~T}_{\mathrm{mr}}=10 \mathrm{~s}, \mathrm{G}_{\mathrm{f}}=30 \mathrm{~s}^{-1}, \mathrm{~T}_{\mathrm{f}}=20 \mathrm{~min}$. a) $\mathrm{Vs}=1,5$ $\mathrm{cm} \cdot \mathrm{min}^{-1}$; b) $\mathrm{Vs}=2,0 \mathrm{~cm} \cdot \mathrm{min}^{-1}$

Figura 5.3- - Diagramas de coagulação utilizando PAC, para uma água de estudo com turbidez em torno de $100 \mathrm{uT}$, expresso em termos de porcentagem de remoção de turbidez, para as seguintes condições: $\mathrm{G}_{\mathrm{mr}}=1000 \mathrm{~s}^{-1}, \mathrm{~T}_{\mathrm{mr}}=10 \mathrm{~s}, \mathrm{G}_{\mathrm{f}}=30 \mathrm{~s}^{-1}, \mathrm{~T}_{\mathrm{f}}=20 \mathrm{~min}$. a) $\mathrm{Vs}=3,0$ $\mathrm{cm} \cdot \mathrm{min}^{-1}$; b) Vs= 4,0 cm. $\min ^{-1}$

Figura 5.4- Turbidez da água decantada em função das condições de mistura rápida (tempo e gradiente). Condições: $T_{\mathrm{f}}=20 \mathrm{~min}, \mathrm{G}_{\mathrm{f}}=30 \mathrm{~s}^{-1}$. a) até d), dosagem de $\mathrm{PAC}=20 \mathrm{mg} \cdot \mathrm{L}^{-1} \mathrm{e}$ $\mathrm{pH} \cong 7$. e) até h), dosagem de $\mathrm{PAC}=55 \mathrm{mg} \cdot \mathrm{L}^{-1}$ e $\mathrm{pH} \cong 7,2$. a) $\mathrm{Vs}=1,5 \mathrm{~cm} \cdot \mathrm{min}^{-1}$; b) $\mathrm{Vs}=2,0$ $\mathrm{cm} \cdot \mathrm{min}^{-1}$; c) $\mathrm{Vs}=3,0 \mathrm{~cm} \cdot \mathrm{min}^{-1}$; d) $\mathrm{Vs}=4,0 \mathrm{~cm} \cdot \mathrm{min}^{-1}$; e) $\mathrm{Vs}=1,5 \mathrm{~cm} \cdot \mathrm{min}^{-1}$; f) $\mathrm{Vs}_{\mathrm{s}}=2,0$ $\mathrm{cm} \cdot \mathrm{min}^{-1}$; g) Vs=3,0 cm.min ${ }^{-1}$ h) Vs $=4,0 \mathrm{~cm} \cdot \mathrm{min}^{-1}$

Figura 5.5- Turbidez da água decantada em função das condições de mistura lenta (tempo e gradiente). Condições: $\mathrm{T}_{\mathrm{mr}}=10 \mathrm{~s}, \mathrm{G}_{\mathrm{mr}}=1000 \mathrm{~s}^{-1}$. a) até d), dosagem de $\mathrm{PAC}=20 \mathrm{mg} \cdot \mathrm{L}^{-1} \mathrm{e}$ $\mathrm{pH} \cong 7$. e) até h), dosagem de $\mathrm{PAC}=55 \mathrm{mg} \cdot \mathrm{L}^{-1}$ e $\mathrm{pH} \cong 7,2$. a) $\mathrm{Vs}=1,5 \mathrm{~cm} \cdot \mathrm{min}^{-1}$; b) $\mathrm{Vs}=2,0$ cm.min ${ }^{-1}$; c) $\mathrm{Vs}=3,0 \mathrm{~cm} \cdot \mathrm{min}^{-1}$; d) $\mathrm{Vs}=4,0 \mathrm{~cm} \cdot \mathrm{min}^{-1}$; e) $\mathrm{Vs}=1,5 \mathrm{~cm} \cdot \mathrm{min}^{-1}$; f) $\mathrm{Vs}=2,0$ $\left.\mathrm{cm} \cdot \mathrm{min}^{-1} ; \mathrm{g}\right) \mathrm{Vs}=3,0 \mathrm{~cm} \cdot \mathrm{min}^{-1}$; e h) Vs=4,0 cm. $\mathrm{min}^{-1}$

Figura 5.6- Diagramas de coagulação para água de estudo com turbidez em torno de 100 uT, expresso em termos de porcentagem de remoção de turbidez, utilizando PAC para as seguintes condições: i) dosagem de PAC entre 10 a $35 \mathrm{mg} / \mathrm{L}: \mathrm{G}_{\mathrm{mr}}=900 \mathrm{~s}^{-1}, \mathrm{~T}_{\mathrm{mr}}=15 \mathrm{~s}, \mathrm{G}_{\mathrm{f}}=$ $30 \mathrm{~s}^{-1}, \mathrm{~T}_{\mathrm{f}}=20 \mathrm{~min}$ e $\mathrm{Vs}=1,5 \mathrm{~cm} \cdot \mathrm{min}^{-1}$; e ii) dosagem de PAC entre 40 a $65 \mathrm{mg} / \mathrm{L}: \mathrm{G}_{\mathrm{mr}}=$ $1000 \mathrm{~s}^{-1}, \mathrm{~T}_{\mathrm{mr}}=15 \mathrm{~s}, \mathrm{G}_{\mathrm{f}}=20 \mathrm{~s}^{-1}, \mathrm{~T}_{\mathrm{f}}=20 \mathrm{~min}$ e a) Vs=1,5 cm.min ${ }^{-1}$; b) Vs $=2,0 \mathrm{~cm} \cdot \mathrm{min}^{-1}$. 96

Figura 5.7- Diagramas de coagulação para água de estudo com turbidez em torno de 100 uT, expresso em termos de porcentagem de remoção de turbidez, utilizando PAC para as seguintes condições: i) dosagem de PAC entre 10 a $35 \mathrm{mg} / \mathrm{L}: \mathrm{G}_{\mathrm{mr}}=900 \mathrm{~s}^{-1}, \mathrm{~T}_{\mathrm{mr}}=15 \mathrm{~s}, \mathrm{G}_{\mathrm{f}}=$ $30 \mathrm{~s}^{-1}, \mathrm{~T}_{\mathrm{f}}=20 \mathrm{~min}$; ii) dosagem de PAC entre 40 a $65 \mathrm{mg} / \mathrm{L}: \mathrm{G}_{\mathrm{mr}}=1000 \mathrm{~s}^{-1}, \mathrm{~T}_{\mathrm{mr}}=15 \mathrm{~s}, \mathrm{G}_{\mathrm{f}}$ $=20 \mathrm{~s}^{-1}, \mathrm{~T}_{\mathrm{f}}=20 \mathrm{~min}$ e a) $\mathrm{Vs}=3,0 \mathrm{~cm} \cdot \mathrm{min}^{-1}$; e b) Vs $=4,0 \mathrm{~cm} \cdot \mathrm{min}^{-1}$

Figura 5.8- a) Aspecto do poço na lâmina de microscopia quando a alíquota do sedimento concentrado da água de estudo fora de $50 \mu \mathrm{L}$; b) visualização em RID do poço de lâmina de microscopia montado com alíquota de $50 \mu \mathrm{L}$

Figura 5.9- Cisto de Giardia spp. e oocisto de Cryptosporidium spp. nos testes preliminares de controle de qualidade; a.1) cisto de Giardia spp. em microscopia de fluorescência, filtro FITC (excitação $\lambda=450$ a $490 \mathrm{~nm}$ e barreira $\lambda=520 \mathrm{~nm}$ ); a.2) cisto de Giardia spp. em microscopia de fluorescência, filtro WG ( $\lambda=510$ a $550 \mathrm{~nm}$ e barreira $\lambda=$ 600 a 660 nm), presente na suspensão Color Seed®; b.1) oocisto de Cryptosporidium spp. 
em microscopia de fluorescência, filtro FITC; b.2) oocisto de Cryptosporidium spp. em

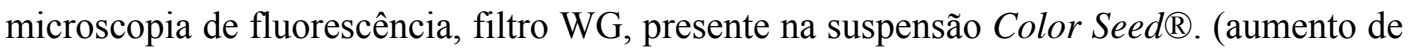
400x)

Figura 5.10- Estruturas com características semelhantes aos cistos Giardia spp. a) estrutura 1 visualizada em fluorescência em FITC (excitação $\lambda=450$ a $490 \mathrm{~nm}$ e barreira $\lambda=520 \mathrm{~nm}$ ) b) estrutura 1 visualizada em DIC; c) estrutura 2 visualizada em fluorescência em FITC; d) estrutura 2 visualizada em microscopia DIC - (aumento de $400 \mathrm{x}$ )

Figura 5.11- Cistos de Giardia spp oocisto de Cryptosporidium spp. (suspensão controle positivo do kit Merifluor ${ }^{\circledR}$ ), visualizados em um mesmo campo (aumento de 400x)

Figura 5.12- Imagens de microscopia do teste de controle de qualidade com separação imunomagnética, com aumento de 400x; a.1) cisto de Giardia spp. em microscopia de fluorescência e filtro de FITC; a.2) cisto de Giardia spp. em microscopia de fluorescência e filtro de DAPI; a.3) cisto de Giardia spp. em microscopia DIC; b.1) oocisto de Cryptosporidium spp. em microscopia de fluorescência e filtro de FITC; b.2) cisto de Cryptosporidium spp. em microscopia de fluorescência e filtro de DAPI; b.3) cisto de Cryptosporidium spp. em microscopia DIC.

Figura 5.13- Aspecto de um poço de lâmina de microscopia de imunofluorescência contendo alíquota de amostra de lodo, sem purificação por IMS, visualização em microscopia de fluorescência em comprimento de onda excitação $\lambda=450$ a $490 \mathrm{~nm}$ e barreira $\lambda=520 \mathrm{~nm}$ (aumento de 400x).

Figura 5.14- Imagem de cisto de Giardia spp. aderido à uma microesfera magnética. a) visualização em RID; b) visualização em DIC (Aum: 400x).

Figura 5.15- Resultados de Bustamante et al.(2001) para o efeito do $\mathrm{pH}$ no potencial zeta de: (•) oocistos de Cryptosporidium; ( $\boldsymbol{\Delta}$ ) flocos de alumínio sozinhos (sem oocistos); oocistos na presença de $6,8 \mathrm{mg} . \mathrm{L}^{-1}$ de Alumínio; linha tracejada representa o $\mathrm{pH}$ de coagulação da primeira condição de coagulação do presente estudo, a linha pontilhada representa o pH de coagulação da segunda condição (FONTE: Bustamante et al, 2001(adaptado))

Figura 0.1- Elementos de difícil interpretação; a) objeto semelhante ao cisto Giardia spp., apresentou coloração vermelha na microscopia de fluorescência em FITC, aumento de 400x; a.1) imagem de microscopia em fluorescência FITC, a.2) imagem de microscopia em fluorescência DAPI, a.3) imagem em microscopia DIC; b) objeto com formato idêntico a um oocisto de Cryptosporidium spp., tamanho maior que a referência do método USEPA 1623.1, aumento de 400x; b.1) imagem de microscopia em fluorescência FITC, b.2) imagem de microscopia em fluorescência DAPI, b.3) imagem em microscopia DIC.

Figura 0.2- Imagens típicas visualizadas nas análises de microscopia em testes com purificação por IMS a) cisto de Giardia spp. aumento de 400x, a.1) visualização em 
fluorescência FITC, a.2) visualização em fluorescência DAPI, a.3) visualização em DIC; b) oocisto de Cryptosporidium spp., b.1) visualização em fluorescência FITC, b.2) visualização em fluorescência DAPI, b.3) visualização em DIC

Figura 0.3- Imagens típicas da visualização de (oo)cistos na microscopia de FITC, quando não ocorreu purificação por IMS; a), b,) e c) se referem aos cistos de Giardia spp. visualizados em amostras de água bruta; d) e e) se referem à oocistos de Cryptosporidium spp. visualizados em amostras de água bruta.

Figura 0.4- Imagens de microscopia de (oo)cistos visualizados na água filtrada quando se utilizou a purificação por IMS; a) cisto de Giardia spp. em aumento de 400x a.1) microscopia de fluorescência em FITC, a.2) microscopia de fluorescência em DAPI, a.3) microscopia DIC; b) oocisto de Cryptosporidium spp. b.1) microscopia de fluorescência em DAPI, b.2) microscopia de fluorescência em DAPI, b.3) microscopia DIC 


\section{LISTA DE TABELAS}

Tabela 3.1- Resumo das espécies de Cryptosporidium (SLAPETA, 2013)...

Tabela 4.1- Equipamentos e métodos empregados para análise das variáveis físicas e químicas

Tabela 5.1- Variáveis relacionadas diretamente à contaminação de mananciais por cistos de Giardia e oocistos de Cryptosporidium

Tabela 5.2- Ensaios de sedimentação da caulinita em Cone Inhoff para a obtenção da turbidez de água matriz conforme metodologia indicada em Di Bernardo (2004).

Tabela 5.3- Ensaios de definição da massa de caulinita em função da turbidez para 2,0 L de água do poço da EESCC/USP

Tabela 5.4 - Características Físicas, Químicas e Microbiológicas nas Águas do Poço e de Estudo

Tabela 5.5 - Parâmetros Iniciais dos Ensaios de Tratabilidade

Tabela 5.6- Turbidez efluente do FLA de acordo com a dosagem de coagulante PAC todos os filtros possuíam condições idênticas de operação.

Tabela 5.7- Características físicas, químicas e microbiológicas da água efluente dos FLAs ..... 98 Tabela 5.8- Recuperação de (oo)cistos nos primeiros ensaios com ColorSeed ${ }^{\circledR}$ para água de estudo com turbidez elevada (129 uT), método de concentração por filtração em membranas e ausência de purificação por IMS

Tabela 5.9- Recuperação de (oo)cistos para água de estudo (matriz com turbidez elevada $\sim 126$ uT) e água reagente (Milli-Q), método de concentração de protozoários por filtração em membranas em testes com separação imunomagnética, em dissociação ácida ou térmica. 103 Tabela 5.10- Recuperação de (oo)cistos para água de estudo (matriz com turbidez elevada 126 uT), método de concentração de protozoários por filtração em membranas em testes sem separação imunomagnética, com disposição de alíquotas em 5 poços de lâminas de imunofluorescênia .

Tabela 5.11- Recuperação de (oo)cistos para água de estudo (matriz com turbidez elevada $\sim 120$ uT), método de concentração de protozoários por filtração em membranas em testes com separação imunomagnética e dissociação ácida

Tabela 5.12- Recuperação de (oo)cistos para água de estudo (matriz com turbidez elevada $\sim 120$ uT), método de concentração de protozoários por filtração em membranas em testes com e sem o uso de separação imunomagnética

Tabela 5.13- Recuperação de (oo)cistos para água de estudo (matriz com turbidez elevada $\sim 120$ uT), realizados na metade dos experimentos, método de concentração de protozoários por filtração em membranas em testes com e sem o uso de separação imunomagnética. 
Tabela 5.14 (cont.)- Recuperação de (oo)cistos para água de estudo (matriz com turbidez elevada $\sim 120 \mathrm{uT}$ ), realizados na metade dos experimentos, método de concentração de protozoários por filtração em membranas em testes com e sem o uso de separação imunomagnética

Tabela 5.15- Número de oocistos e cistos detectados nas diferentes etapas do tratamento proposto, mediante o uso da técnica de filtração em membranas, sem a purificação por separação imunomagnética, após inoculação de número conhecido de protozoários

Tabela 5.16- Número de cistos de Giardia spp. detectados nos ensaios de tratabilidade para a primeira condição de coagulação (dose de $25 \mathrm{mg} . \mathrm{L}^{-1}$ de PAC e ausência de correção de $\mathrm{pH})$ quando a purificação por IMS não foi empregada e remoção $\left(\mathrm{em} \log _{10}\right)$.....

Tabela 5.17- Número de cistos de Giardia spp. detectados nos ensaios de tratabilidade para a segunda condição de coagulação (dose de $65 \mathrm{mg} \cdot \mathrm{L}^{-1}$ de PAC e $15 \mathrm{mg} . \mathrm{L}^{-1}$ de $\mathrm{NaOH}$ ) quando a purificação por IMS não foi empregada e remoção $\left(\mathrm{em} \log _{10}\right)$.....

Tabela 5.18- Número de oocistos de C. parvum detectados nos ensaios de tratabilidade para a primeira condição de coagulação (dose de $25 \mathrm{mg} \cdot \mathrm{L}^{-1}$ de PAC e ausência de correção de $\mathrm{pH})$ quando a purificação por IMS não foi empregada e remoção $\left(\mathrm{em} \log _{10}\right)$.

Tabela 5.19- Número de oocistos de C. parvum detectados nos ensaios de tratabilidade para a segunda condição de coagulação (dose de $65 \mathrm{mg} . \mathrm{L}^{-1}$ de PAC e $15 \mathrm{mg} . \mathrm{L}^{-1}$ de $\mathrm{NaOH}$ ) quando a purificação por IMS não foi empregada e remoção $\left(\log _{10}\right)$

Tabela 5.20- Número de cistos de Giardia spp. detectados nos ensaios de tratabilidade para a primeira condição de coagulação, em diferentes etapas, (dose de $25 \mathrm{mg} . \mathrm{L}^{-1}$ de PAC e ausência de correção de $\mathrm{pH})$ com emprego de IMS e remoção $\left(e m \log _{10}\right)$

Tabela 5.21- Número de cistos de Giardia spp. detectados nos ensaios de tratabilidade para a segunda condição de coagulação, em diferentes etapas, (dose de $65 \mathrm{mg} . \mathrm{L}^{-1}$ de PAC e 15 mg. $L^{-1}$ de $\left.\mathrm{NaOH}\right)$ com emprego de IMS e remoção (em $\left.\log _{10}\right)$

Tabela 5.22- Número de oocistos de C. parvum por litro nos ensaios de tratabilidade para a primeira condição de coagulação (dose de $25 \mathrm{mg} \cdot \mathrm{L}^{-1}$ de PAC e ausência de correção de pH) com o emprego de purificação por IMS e remoção $\left(\log _{10}\right)$.

Tabela 5.23- Número de oocistos de C. parvum por litro nos ensaios de tratabilidade para a segunda condição de coagulação (dose de $65 \mathrm{mg} . \mathrm{L}^{-1}$ de PAC e $15 \mathrm{mg} . \mathrm{L}^{-1}$ de NaOH) com o emprego de purificação por IMS e remoção $\left(\log _{10}\right)$.....

Tabela 5.24- Remoção de cistos de Giardia spp. e oocistos de C. parvum de acordo com diferentes condições de coagulação $\left(\mathrm{C} 1=25 \mathrm{mg} \cdot \mathrm{L}^{-1}\right.$ de $\mathrm{PAC}$, sem correção de $\mathrm{pH} ; \mathrm{C} 2=65$ mg. $L^{-1}$ de PAC, com adição de alcalinizante)

Tabela 5.25- Comparação da eficiência de recuperação de cistos de Giardia spp. entre as metodologias com e sem o emprego da separação imunomagnética (IMS) - na água bruta .... 127 
Tabela 5.26- Comparação da eficiência de recuperação de oocistos de C. parvum entre as metodologias com e sem o emprego da separação imunomagnética (IMS) - na água bruta .... 127 Tabela 5.27- Comparação entre o número de (oo)cistos detectados no fim do tratamento, para a primeira condição de coagulação (dosagem de $25 \mathrm{mg} \cdot \mathrm{L}^{-1}$ de PAC e ausência de correção de $\mathrm{pH}$ ), entre as metodologias com e sem o emprego da separação imunomagnética (IMS) - água após filtração

Tabela 5.28- Comparação entre o número de (oo)cistos no fim do tratamento, para a segunda condição de coagulação (dosagem de $65 \mathrm{mg} . \mathrm{L}^{-1}$ de PAC e $15 \mathrm{mg} . \mathrm{L}^{-1}$ de $\mathrm{NaOH}$ ), entre as metodologias com e sem o emprego da separação imunomagnética (IMS) - água após filtração.

Tabela 5.29- Comparativo econômico entre as análises com e sem a etapa de purificação por IMS para uma água de estudo com turbidez em torno de 120 uT (valores de junho de 2014)

Tabela 5.30- Distribuição da porcentagem de recuperação de cistos de Giardia spp. entre a primeira e segunda dissociação ácida no procedimento de IMS

Tabela 5.31- Distribuição da porcentagem de recuperação de oocistos de C. parvum entre a primeira e a segunda dissociação ácida do procedimento de IMS

Tabela 5.32- Variáveis de coagulação relacionadas às concentrações de cistos de Giardia spp. e oocistos de C. parvum na água bruta( $\mathrm{AB}$ ) e "agua filtrada" (AF), na: primeira condição de coagulação (25 mg.. $\mathrm{L}^{-1}$ de PAC, sem correção de pH) (testes 1.1 a 1.4$)$; segunda condição de coagulação (65 mg. $\mathrm{L}^{-1}$ de PAC com adição de alcalinizante) (testes 2.1 a 2.3); ND- não detectado pelo método.

Tabela 5.33- Variáveis físicas e químicas relacionadas às concentrações de cistos de Giardia spp. e oocistos de C. parvum na água bruta(AB) e "agua filtrada" (AF), na: primeira condição de coagulação $\left(25 \mathrm{mg} \cdot \mathrm{L}^{-1}\right.$ de PAC, sem correção de $\mathrm{pH}$ ) (testes 1.1 a 1.4) ; segunda condição de coagulação (65 mg. $\mathrm{L}^{-1}$ de PAC com adição de alcalinizante) (testes 2.1 a 2.3); ND- não detectado pelo método

Tabela 5.34- Valores de $\mathrm{pH}$ nas etapas água decantada e água filtrada para : primeira condição de coagulação (25 mg. $\mathrm{L}^{-1}$ de PAC, sem correção de $\mathrm{pH}$ )- testes 1.1 a 1.4; segunda condição de coagulação (65 mg. $\mathrm{L}^{-1}$ de PAC, com adição de alcalinizante). 


\section{LISTA DE ABREVIATURAS E SIGLAS}

ANOVA - Análise de variância (Analysis of variance)

$\mathrm{Al}_{2} \mathrm{O}_{3}$ - óxido de alumínio ou alumina

1623.1 - método de detecção de Giardia e Cryptsporidium da USEPA

$\mathrm{Ct}$ - concentração de desinfectante vezes tempo de contato

CV - coeficiente de variação (desvio padrão relativo à média)

DAPI - 4',6-diamino-2fenil-indol

DIC - Microscopia de contraste interferencial diferencial

DNA - Ácido Desoxirribonucleico

EESC - Escola de Engenharia de São Carlos

FITC - Isotiocianato de fluoresceína

FLA - filtro de laboratório de areia

$\mathrm{G}$ - aceleração da gravidade

$\mathrm{G}_{\mathrm{mr}}$ - gradiente de mistura rápida

$\mathrm{G}_{\mathrm{f}}-$ gradiente médio de velocidade na floculação

GAC - Carvão ativado granular

IMS - Separação Imunomagenética

LATAR - Laboratório de Tratamento Avançado e Reúso de Água

$\log _{10}-$ logaritmo de base 10

MPC-1-Concentrador de partículas magnéticas 1

MPC-S - Concentrador de partículas magnéticas 2

$\mathrm{OH}^{-}-$hidroxila

PAC - Cloreto de polialumínio

PCR - Reação em cadeia de Polimerase 
pH - Potencial hidrogeniônico

$\mathrm{T}_{\mathrm{mr}}-$ tempo de mistura rápida

$\mathrm{T}_{\mathrm{f}}$ - tempo de floculação

TLP - Tubo de lado plano

USEPA - Agência de proteção ambiental dos Estados Unidos

USP - Universidade de São Paulo

Vs - velocidade de sedimentação

uT - unidade de turbidez (unidade nefolométrica de turbidez) 


\section{SUMÁRIO}

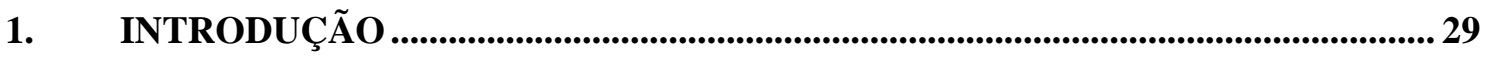

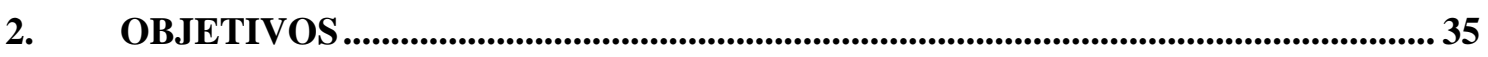

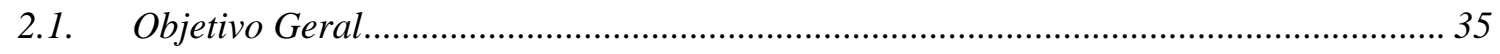

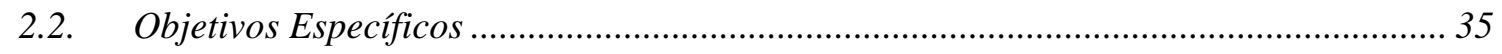

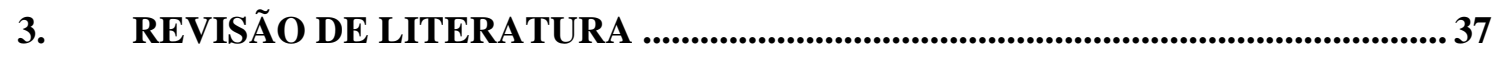

3.1. Características e ciclo de vida das espécies de Giardia e Cryptosporidium.................... 37

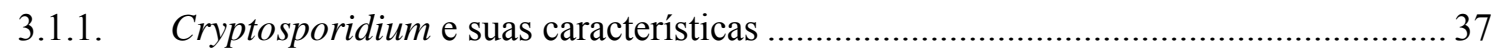

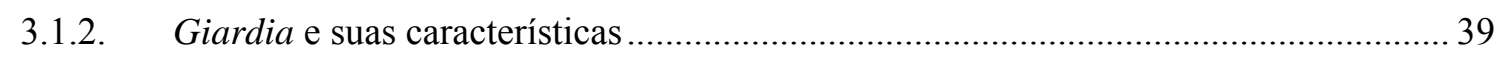

3.2. Surtos documentados de Giardiose e Cryptosporidiose …............................................. 40

3.3. Monitoramento da ocorrência de cistos de Giardia spp. e oocistos de

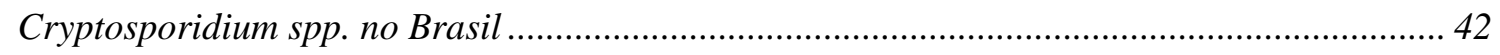

3.4. Metodologias para a identificação de (oo) cistos de protozoários.................................... 43

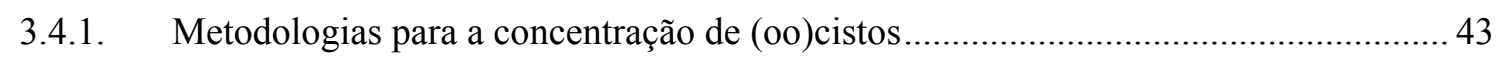

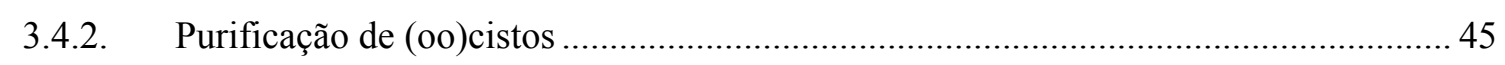

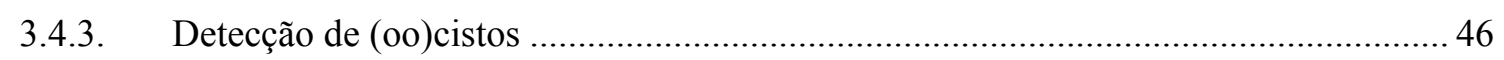

3.5. Remoção de (oo) cistos por técnicas de tratamento de Água .......................................... 48

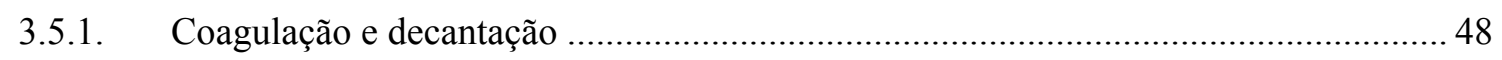

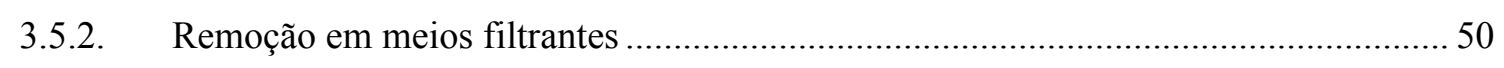

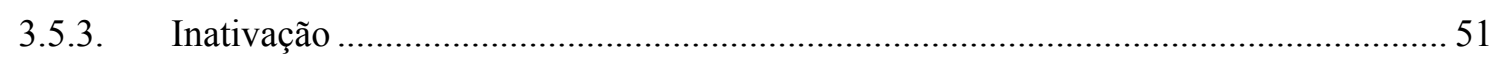

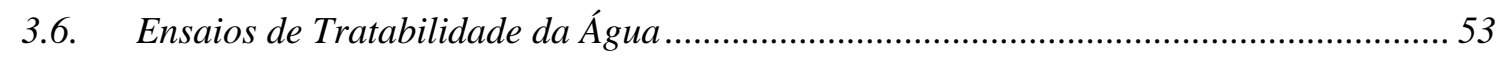

3.7. Emprego de Cloreto de Polialumínio como Coagulante ………………......................... 53

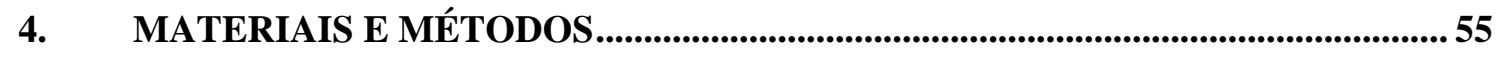

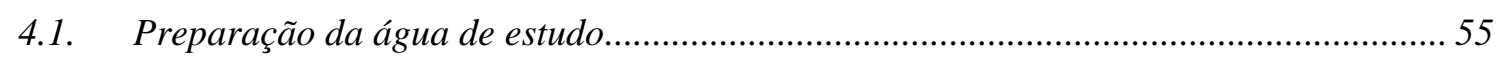

4.1.1. Preparação da água de estudo com pré-decantação....................................................... 56 
4.2. Ensaios de tratabilidade da água de estudo

4.3. Controle da qualidade analítica do método de avaliação de protozoários em águas.... 58

4.3.1. Detalhes do Controle de Qualidade Analítica na Água de Estudo 59

4.4. Ensaios de tratabilidade da água com inóculo de protozoários

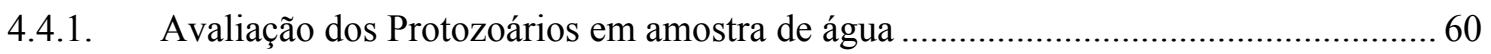

4.4.2. Experimentos em escala de bancada para remoção de (oo)cistos de Protozoários ..... 75

4.5. Análises de variáveis físicas e químicas. 81

4.6. Análise estatística

4.7. Construção de modelo multi-variáveis para a transmissão de giardiose $e$ criptosporidiose.

5. RESULTADOS E DISCUSSÃO

5.1. Proposta de um modelo multi-variáveis para o ciclo da transmissão da giardiose e criptosporidiose

5.2. Preparação da água de estudo.

5.3. Ensaios de tratabilidade em escala de bancada

5.4. Ensaios de controle da qualidade do método de identificação de protozoários. 99

5.4.1. Ensaios de controle de qualidade do método de identificação de protozoários sem o uso do procedimento de separação imunomagnética (IMS).

5.4.2. Ensaios de controle da qualidade do método de identificação de protozoários com o uso da separação imunomagnética .

5.4.3. Ensaios intermediários do controle de qualidade do método de identificação de protozoários

5.5. Ensaios de tratabilidade da água de estudo com inóculos de protozoários ....

5.5.1. Ensaios de tratabilidade da água de estudo sem o emprego da metodologia de separação imunomagnética para a identificação de protozoários. 
5.5.2. Ensaios de tratabilidade da água de estudo com o emprego da metodologia de separação imunomagnética para a identificação de (oo)cistos de protozoários

5.6. Comparação entre os procedimentos sem e com a etapa de purificação por IMS ........ 126

5.7. Estudo da distribuição da recuperação de cistos de Giardia spp. e oocistos de C. parvum nas dissociações ácidas do procedimento com IMS

5.8. Avaliação do desempenho das duas condições de coagulação propostas na remoção de cistos de Giardia spp. e oocistos de C. parvum.

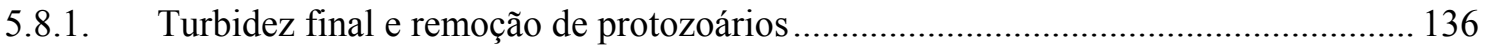

5.8.2. Variáveis de controle da coagulação e remoção de protozoários ................................ 137

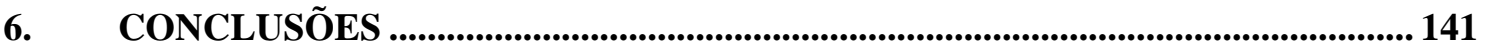

7. RECOMENDAÇÕES A FUTUROS TRABALHOS .............................................. 143

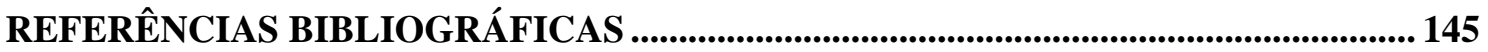

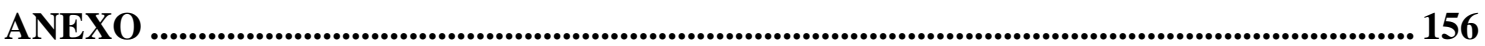

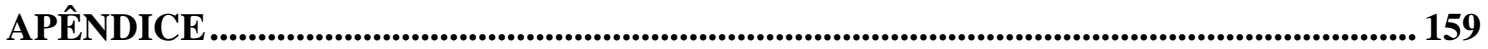




\section{INTRODUÇÃO}

O acesso à água com qualidade adequada para o consumo é um direito humano básico e componente de política eficaz de proteção à saúde (WHO, 2011). Sistemas efetivos de proteção de mananciais, coleta e tratamento de efluentes (domésticos e industriais), disposição adequada de resíduos sólidos e abastecimento de água com segurança para o consumo refletem em redução de gastos públicos com tratamento de doenças evitáveis. Além disso, há melhoras em quadros de absenteísmo de trabalhadores, o que representam consequências econômicas da falta dessa estrutura básica.

Em vista desta situação, ações que promovam o desenvolvimento dos sistemas de saneamento são essenciais para a promoção da saúde pública e da qualidade de vida. Neste sentido, o tratamento de água é o componente dos sistemas de saneamento mais diretamente associado à proteção da saúde humana. A exposição a contaminantes microbiológicos pode ser eliminada por meio de um sistema efetivo de tratamento de água, o que seria a etapa crítica do conceito de múltiplas barreiras, estas que começam na proteção aos mananciais e vão até a proteção dos sistemas de distribuição de água potável (GOMES e AZEVEDO,2006).

Para assegurar a qualidade microbiológica da água, é necessário o estabelecimento de organismos alvos de remoção. Os alvos precisam ser realistas, mensuráveis, baseados em dados científicos e relevantes às condições locais (WHO, 2011). Neste contexto, os protozoários Giardia spp. e Cryptosporidium spp. se apresentam como organismos fundamentais para indicação do fornecimento de água com qualidade aceitável. Estes patógenos já foram identificados em muitos mananciais brasileiros (CANTUSIO NETO et al,. 2010; DIAS et al., 2008; FRANCO et al., 2001; SATO et al., 2013) e são considerados de difícil remoção e inativação por sistemas convencionais de tratamento de água.

Giardia e Cryptosporidium $^{1-}$ são protozoários que se apresentam em ambiente natural em suas formas de resistência (cistos e oocistos, respectivamente). Estes organismos necessitam de um hospedeiro para completarem seus ciclos de vida. Eles são capazes de causar infecções em seres humanos, tendo como principal sintoma eventos de diarreia, e apresentam considerável persistência em ambientes aquáticos. A presença destes protozoários

${ }^{1}$ Neste trabalho, o uso do termo Giardia e Cryptosporidium se referirá à espécies genéricas destes protozoários, como forma de abreviação à Giardia spp. e Cryptosporidium spp. 
nestes ambientes é geralmente associada ao lançamento inadequado de efluentes domésticos e às atividades pecuárias nas proximidades dos mananciais (DIAS et al. , 2008; CANTUSIO NETO et al., 2010).

No cenário internacional, muita atenção se volta ao controle da presença de Giardia e Cryptosporidium, pois existe extensa documentação de surtos de giardiose e criptosporidiose. Giardia e Cryptosporidium foram considerados responsáveis por 35,2\% e $60,3 \%$, respectivamente, dos surtos mundiais de protozoonoses ocorridos entre 2004 e 2010 (BALDURSON e KARANIS, 2011). Um surto de criptosporidiose já foi capaz de causar infecção à cerca de 400 mil pessoas na cidade de Milwaukee, nos Estados Unidos (MACKENZIE et al., 1994).

A maior parte destes surtos foi documentada em países desenvolvidos, pois estes possuem sistemas de vigilância eficientes. A falta destes sistemas em países em desenvolvimento faz com que problemas relacionados à presença de agentes contaminantes microbiológicos, em águas destinadas ao consumo, sejam contemporizados.

Neste sentido, mesmo que não tenha havido documentação de surtos de giardiose e criptosporidiose relacionados à veiculação hídrica no Brasil, a ocorrência destes protozoários em mananciais representa séria preocupação às autoridades de saúde pública. Outras protozoonoses já apresentaram surtos no cenário nacional, como os causados pelos protozoários Toxoplasma gondii e Cyclospora cayetanensis (FRANCO, 2007), fato que indica vulnerabilidade dos sistemas de tratamento e distribuição de água.

A complexidade acerca da ameaça de espécies de Giardia e Cryptosporidium se inicia pela dificuldade envolvida na detecção destes protozoários. Os métodos existentes são caros, imprecisos (existe variabilidade de recuperação), possuem resposta demorada e exigem pessoal qualificado para suas realizações (FRANCO, BRANCO e LEAL, 2012).

Existem métodos padronizados que buscam uma forma de aumentar a confiabilidade dos ensaios de detecção de protozoários. O Método 1623.1 da USEPA (2012) é um método validado, compreendendo etapas de concentração, purificação e detecção em microscopia de fluorescência. Além disso, há estabelecimento de padrões de aceitação em termos de porcentagem de recuperação de um número conhecido de (oo)cistos. Estes padrões fazem com que haja melhor significado de resultados de pesquisas científicas respaldadas por esta metodologia.

No entanto, a existência de metodologias bem delineadas para a identificação de protozoários não diminui a dificuldade da realização destes testes. Os reagentes, materiais de 
consumo e materiais permanentes representam altos custos, o que inviabiliza a realização destes ensaios em rotinas das companhias responsáveis pela produção de água potável na realidade brasileira. Como alternativa a este problema, o próprio Método 1623.1 (2012) reconhece a possibilidade de adaptações às suas etapas, desde que os resultados de porcentagem de recuperação estejam dentro dos critérios de aceitação que constam no Método.

Neste contexto, a concentração de protozoários pelo método de filtração em membranas, proposta por Franco, Rocha-Eberhardt e Cantusio Neto (2001), apresenta-se como boa alternativa para a redução de custos nesse tipo de análise. Este método foi amplamente utilizado nas duas últimas décadas para análise da ocorrência de cistos de Giardia e oocistos de Cryptosporidium em águas naturais (BRANCO, 2006; CANTUSIO NETO et al., 2010; FRANCO et al., 2001) e tratadas (CANTUSIO NETO, 2004). Pesquisas que apliquem este protocolo em águas com condições extremas de turbidez são bem-vindas, uma vez que esta condição é uma espécie de limitadora do método.

Acresce que o alto custo das análises de Giardia e Cryptosporidium de acordo com o Método 1623.1 (USEPA, 2012), não se restringe à etapa de concentração. Neste método fíca estabelecida, também, uma etapa de purificação das amostras. Esta etapa é chamada purificação por separação imunomagnética - IMS.

Quanto se realiza a IMS, existe a possibilidade de a amostra ser integralmente analisada, sem a tomada de alíquotas, além de haver remoção de muitos interferentes, o que permite uma leitura em microscopia mais clara. No entanto, esta etapa é crítica na análise de protozoários, pois possui um alto custo. O Método aceita a supressão da etapa de IMS (com aplicação da amostra concentrada em poços múltiplos de lâminas de microscopia), desde que haja estudos de validação da metodologia.

Uma vez que haja a definição de metodologias para a concentração de cistos de Giardia e oocistos de Cryptosporidium, possibilita-se o estudo da dinâmica destes organismos em diversos ambientes. Desde ambientes naturais, como mananciais e solos, passando por todas as etapas do tratamento de água, como o isolamento na forma de lodo, até a ocorrência em esgotos e diversas etapas do tratamento deste. Neste ponto, fica claro que existem particularidades dos meios em que os (oo)cistos podem se encontrar e que elas são determinantes na escolha da metodologia empregada para a suas identificações. O Método 1623.1 é próprio para o monitoramento de (oo)cistos em águas naturais e tratadas. 
A respeito do tratamento de águas com presença de (oo)cistos de Giardia e Cryptosporidium, definidas as condições de identificação destes, torna-se possível o estudo mais aprofundado de suas remoções pelas tecnologias existentes. O estudo começa pela análise das características físicas destas espécies.

Os cistos de Giardia apresentam dimensões aproximadas de 8-18 $\mu \mathrm{m}$, já os oocistos de Cryptosporidium apresentam de 4 a $6 \mu \mathrm{m}$ de diâmetro (USEPA, 2012). Com estas dimensões, são potencialmente removíveis no meio filtrante de estações de tratamento de água - ETAs, apesar da capacidade de compressibilidade de oocistos de Cryptosporidium, que podem se comportar como partículas de 2 a $4 \mu \mathrm{m}$ (FRANCO, 2007). Além do pequeno tamanho, a forma encistada destes protozoários é consideravelmente resistente à inativação com o uso de cloro (KORICH et al., 1990).

Torna-se fundamental a maximização do desempenho das etapas de remoção física de (oo)cistos de protozoários, para que os sistemas de tratamento sejam capazes de distribuir água com segurança microbiológica, a respeito destes contaminantes. Esta maximização pode ser alcançada mediante o estudo das condições de coagulação, na observância do comportamento dos (oo)cistos frente às diferentes estratégias e aos agentes coagulantes. $\mathrm{O}$ sucesso da etapa de coagulação é essencial para a remoção de (oo)cistos no meio filtrante.

A maioria das pesquisas brasileiras que avalia a remoção de Giardia e Cryptosporidium em águas de abastecimento tem-se centrado no uso de sulfato de alumínio como coagulante. Alternativamente, no país, mais recentemente, têm-se reportado aplicações do uso de cloreto de polialumínio - PAC em ETAs (LOPES et al. 2009; FERREIRA FILHO \& WAELKENS, 2009). O principal atrativo do PAC é a eventual não necessidade de aplicação de préalcalinização, o que resulta em grande vantagem do ponto de vista operacional, quando comparado aos demais coagulantes tradicionais.

A recente regulamentação brasileira sobre água potável, Portaria MS 2914/2011 (BRASIL, 2011), estabeleceu, a partir de dezembro de 2013, a obrigatoriedade do monitoramento de cistos de Giardia e oocistos de Cryptosporidium por agências responsáveis pelo tratamento e distribuição de água. A obrigatoriedade acontece quando for identificada média geométrica anual maior ou igual a 1000 Escherichia coli por cada $100 \mathrm{~mL}$. Este monitoramento é essencial, pois, embora haja uma série de dificuldades relacionadas à identificação destes protozoários, não há variável de rotina adequada à indicação de suas presenças. Desta forma, é de grande relevância a validação de testes de identificação 
aplicáveis à realidade brasileira e o estudo do desempenho dos sistemas de tratamento de água na remoção específica dos (oo)cistos de Giardia e Cryptosporidium.

Neste contexto, o presente estudo avaliou o desempenho de duas condições de coagulação (25 mg.L $\mathrm{L}^{-1}$ de PAC, sem correção de pH e $65 \mathrm{mg} . \mathrm{L}^{-1}$ de PAC com adição de alcalinizante) na remoção de cistos de Giardia e oocistos de Cryptosporidium, em escala de bancada (coagulação seguida de floculação, decantação e filtração). Tomou-se como partida, uma água com turbidez aumentada a valores acima de 100 uT, com adição de caulinita, e com número estimado destes protozoários inoculados. Os resultados deste trabalho orientarão futuras pesquisas que intencionem utilizar o coagulante PAC, para a remoção de (oo)cistos de Giardia e Cryptosporidium, em tratamento convencional. Além disso, os resultados dos testes analíticos utilizados para a detecção de protozoários poderão auxiliar as empresas que possuem obrigatoriedade legal de fazer este tipo de análise. Ainda mais, o estudo das variáveis de coagulação será capaz de dar um indicativo das melhores condições para a remoção destes protozoários. 


\section{OBJETIVOS}

\subsection{OBJETIVo GeraL}

Avaliar a remoção de cistos de Giardia spp. e oocistos de Cryptosporidium spp. em águas de abastecimento com turbidez elevada, em ensaios de bancada, utilizando coagulação, floculação, decantação, filtração.

\subsection{OBJETIVOS ESPECÍfICOS}

- Propor um modelo multi-variáveis para explicar a transmissão de giardiose e criptosporidiose

- Avaliar a aplicabilidade do coagulante cloreto de polialumínio para o tratamento de água com turbidez elevada;

- Avaliar o método de concentração de protozoários por filtração em membranas, descrito por Franco, Rocha-Eberhardt e Cantusio Neto (2001), com adaptações, em águas com turbidez elevada;

- Avaliar a viabilidade da retirada da etapa de purificação por separação imunomagnética na detecção de protozoários; e

- Estudar o desempenho de duas condições de coagulação, obtidas em diagramas de coagulação com cloreto de polialumínio, na remoção de (oo)cistos de protozoários. 


\section{REVISÃO DE LITERATURA}

\subsection{CARACTERÍSTICAS E CICLO DE VIDA DAS ESPÉCIES DE GIARDIA E CRYPTOSPORIDIUM}

\subsubsection{CRYPTOSPORIDIUM E SUAS CARACTERÍSTICAS}

O gênero Cryptosporidium é pertencente ao Reino Chromalveolata, e Filo Apicomplexa, que compreende parasitas eucarióticos que possuem complexo apical em algum estágio em seu ciclo de vida. É pertencente à Classe Conoidasida, que se reproduzem de forma sexuada e assexuada, e à Ordem Coccidia, que são, geralmente, parasitas intestinais e Sub ordem Eucoccidiorida. O Gênero Cryptosporidium apresenta algumas particularidades em seu ciclo de vida que o diferencia dos outros coccídios, aproximando-os às características dos gregarinas (RYAN e XIAO, 2014).

Este gênero é composto por protozoários parasitas que infectam as microvilosidades das células epiteliais, principalmente do trato intestinal de todas as classes de vertebrados (RYAN e XIAO, 2014). Suas espécies e genótipos apresentam uma alta diversidade biológica, que diferem em sua capacidade de infectar um ou múltiplos hospedeiros e a prevalência de sua infecção varia de acordo com a localização geográfica (XIAO e FAYER, 2008).

A compreensão das dinâmicas de transmissão do Cryptosporidium tem sido tradicionalmente difícil, pois a maioria das espécies são morfologicamente idênticas. Contudo, ferramentas de caracterização molecular como reação em cadeia de polimerase (PCR) e análise do sequenciamento de ácido desoxirribonucleico (DNA) são utilizadas para a identificação e diferenciação confiável de genótipos e espécies (RYAN e XIAO, 2014).

Segundo Slapeta (2013), são reconhecidas 30 espécies de Cryptosporidium e somente entre 2004 e 201310 novas espécies deste gênero foram validadas e as espécies são reconhecidas por pesquisas moleculares e estudos experimentais em todo mundo. No entanto, dentre as espécies nomeadas, existe grande diversidade de formas e genótipos, que poderiam ou não merecer o status de espécie. Ryan e Xiao (2014) consideram a existência de 25 espécies. A Tabela 3.1 apresenta as espécies descritas por Slapeta (2013) com suas relevâncias quanto à saúde pública.

$\mathrm{O}$ ciclo de vida das espécies do gênero Cryptosporidium se completa em um único hospedeiro e inclui estádios de reprodução sexuada e assexuada. Cacciò e Putignani (2014) resumiram o ciclo de vida de Cryptosporidium como se segue. A infecção é adquirida por 
meio da ingestão de oocistos esporulados. No intestino delgado, esporozoítos, do oocisto aberto, se aderem às células epiteliais intestinais e se torna trofozoíto.

Tabela 3.1- Resumo das espécies de Cryptosporidium (SLAPETA, 2013)

\begin{tabular}{|c|c|c|c|c|c|c|}
\hline $\begin{array}{l}\text { Número da } \\
\text { Espécie }\end{array}$ & $\begin{array}{l}\text { Nome validado da } \\
\text { Espécie }\end{array}$ & $\begin{array}{l}\text { Importância para } \\
\text { saúde pública }\end{array}$ & $\begin{array}{l}\text { Gama de } \\
\text { hospedeiros }\end{array}$ & Humanos & Gado & $\begin{array}{l}\text { Designação do } \\
\text { genótipo }\end{array}$ \\
\hline Espécie I & C. muris & Pequena & $\mathrm{M}, \mathrm{A}$ & Sim & $\mathrm{NI}$ & C. muris B genotype \\
\hline Espécie II & C. parvum & Pequena & $\mathrm{M}$ & $(\mathrm{Sim})$ & NI & Mouse I genotype \\
\hline Espécie III & C. meleagridis & Moderada & $\mathrm{M}, \mathrm{A}$ & Sim & $(\mathrm{Sim})$ & \\
\hline Espécie IV & C. wrairi & Nenhuma & $\mathrm{M}$ & (Sim) & NI & \\
\hline Espécie V & C. agni & Nenhuma & $\mathrm{M}$ & NI & NI & C. bovis-like genotype \\
\hline Espécie VI & C. bovis & Nenhuma & $\mathrm{M}$ & NI & Sim & Bovine B genotype \\
\hline Espécie VII & C. cuniculus & Moderada & $\mathrm{M}$ & Sim & $\mathrm{NI}$ & Rabbit genotype \\
\hline Espécie VIII & C. felis & Moderada & $\mathrm{M}$ & Sim & $(\mathrm{Sim})$ & Cat genotype \\
\hline Espécie IX & C. serpentis & Nenhuma & $\mathrm{R}, \mathrm{M}$ & NI & $(\operatorname{Sim})$ & \\
\hline Espécie X & C. nasoris & Nenhuma & $P$ & $\mathrm{NI}$ & $\mathrm{NI}$ & $\mathrm{n} / \mathrm{a}$ \\
\hline Espécie XI & C. baileyi & Nenhuma & A & $\mathrm{NI}$ & NI & \\
\hline Espécie XII & C. varanii & Nenhuma & $\mathrm{R}$ & NI & NI & $\begin{array}{l}\text { Desert monitor } \\
\text { genotype }\end{array}$ \\
\hline Espécie XIII & C. cichlidis & Nenhuma & $P$ & NI & NI & Piscine genotype 1 \\
\hline Espécie XIV & C. reichenbachklinkei & Nenhuma & $P$ & $\mathrm{NI}$ & $\mathrm{NI}$ & Piscine genotype 2 \\
\hline Espécie XV & C. galli & Nenhuma & A & NI & $\mathrm{NI}$ & Finch genotype \\
\hline Espécie XVI & C. andersoni & Pequena & $\mathrm{M}$ & Sim & Sim & C. murisA genotype \\
\hline Espécie XVII & C. canis & Pequena & $\mathrm{M}$ & Sim & (Sim) & Dog genotype \\
\hline Espécie XVIII & C. hominis & Grande & $\mathrm{M}$ & Sim & Sim & Human (I) genotype \\
\hline Espécie XIX & C. molnari & Nenhuma & $P$ & NI & NI & \\
\hline Espécie XX & C. suis & Pequena & $\mathrm{M}$ & (Sim) & Sim & Pig genotype II \\
\hline Espécie XXI & C. scophthalmi & Nenhuma & $P$ & NI & NI & $\mathrm{n} / \mathrm{a}$ \\
\hline Espécie XXII & C. pestis, & Grande & $\mathrm{M}$ & Sim & Sim & Bovine (II) genotype \\
\hline Espécie XXIII & C. fayeri & Pequena & $\mathrm{M}$ & (Sim) & NI & Marsupial genotype I \\
\hline Espécie XXIV & C. ryanae & Nenhuma & $\mathrm{M}$ & NI & Sim & Deer-like genotype \\
\hline Espécie XXV & C. fragile & Nenhuma & & $\mathrm{NI}$ & NI & \\
\hline Espécie XXVI & C. macropodum & Nenhuma & $\mathrm{M}$ & $\mathrm{NI}$ & $\mathrm{NI}$ & Marsupial genotype II \\
\hline Espécie XXVII & C. ducismarci & Nenhuma & $\mathrm{R}$ & $\mathrm{NI}$ & NI & \\
\hline Espécie XXVIII & C. ubiquitum & Pequena & $\mathrm{M}$ & Sim & Sim & Deer genotype \\
\hline Espécie XXIX & C. viatorum & Moderada & $\mathrm{M}$ & Sim & NI & \\
\hline Espécie XXX & C. scrofarum & Pequena & $\mathrm{M}$ & $(\mathrm{Sim})$ & $(\mathrm{Sim})$ & Pig genotype II \\
\hline
\end{tabular}

Notas: M, mamíferos; $\mathrm{A}$, aves; R, répteis; $\mathrm{P}$, peixes. n/a: não aplicável porque a espécie não foi caracterizada usando qualquer assinatura de DNA. (Sim) indica extremamente rara ou experimental evidência. NI: não indicado pelo autor.

O trofozoíto é submetido à replicação assexuada (merogonia), resultando na produção de oito merozoítos (meronte tipo 1). Merozoítos, liberados no lúmen intestinal, infectam 
novas células epiteliais intestinais e dão origem ao meronte tipo 2, caracterizado por 4 merozoítos. Estes merozoítos podem iniciar a fase sexuada se diferenciando em microgametócito e macrogametócito. O microgametócito libera microgametas que podem fertilizar macrogametócitos. O produto da fertilização, o zigoto, se desenvolve em oocisto. Oocistos completamente esporulados (parede espessa) e de parede delgada são liberados no intestino. Os oocistos de parede espessa são liberados nas fezes, os parede delgada, acreditase estarem envolvidos em processos de auto-infecção.

É de particular interesse no estudo de Cryptosporidium a potencial rota de contaminação zoonótica por essas espécies. Segundo Xiao (2010) muitos estudos caracterizaram Sub espécies de C. parvum em animais de fazenda, principalmente bezerros. Segundo o autor supracitado, existem muitas evidências da prevalência das mesmas subespécies caracterizadas nestes animais de fazendas em humanos. Este estudo ainda apontou que a rota zoonótica de transmissão da criptosporidiose é mais importante em países desenvolvidos em comparação aos países em desenvolvimento, nos quais a transmissão antroponótica é prevalente.

\subsubsection{GIARDIA E SUAS CARACTERÍSTICAS}

O Gênero Giardia pertence ao Filo Metamonada, Subfilo Trichozoa, Superclasse Eopharyngia, Classe Trepomonadea, Subclasse Diplozoa, Ordem Giardiida e Família Giardiidae (PLUTZER, ONGERTH E KARANIS, 2010).

Segundo Plutzer, Ongerth e Karanis (2010) seis espécies de Giardia foram distinguidas, com base na microscopia de luz para as formas de seus trofozoítos e conteúdo interno, e microscopia eletrônica (característica da franja ventrolateral, sulco marginal, disco ventral e flagelo). Destas seis espécies, cinco são representadas por isolados de anfíbios (G. agilis), aves (G. ardeae, G. psittaci), roedores (G. muris) e ratazanas (G. microti). A sexta espécie inclui cepas de Giardia isoladas de uma vasta gama de outros hospedeiros mamíferos, agrupadas em uma única espécie (G. duodenalis), porque eles compartilham características morfológicas e, em particular, têm estruturas do conteúdo interno similares.

Giardia duodenalis (sin. G. intestinalis, G. lamblia) é a única espécie do gênero Giardia encontrada em humanos e é o mais comum protozoário parasita de humanos em países desenvolvidos e em desenvolvimento (CACCIÒ e SPRONG, 2011). Muitas características do ciclo de vida da $G$. duodenalis influenciam na epidemiologia da infecção: i) os cistos são imediatamente infecciosos após eliminação em fezes e podem ser transmitidos por contato pessoa-a-pessoa ou animal-a-pessoa; ii) os cistos são notadamente estáveis e podem 
sobreviver por semanas ou meses no ambiente; iii) a contaminação do ambiente pode levar a contaminação de águas de abastecimento e alimentos, ou até mesmo áreas com águas recreativas; iv) a infecção ocorre exclusivamente pela ingestão de cistos, seja por água ou alimentos, ou ingestão acidental de águas de recreação, por contato direto em situações de higiene insuficiente ou em atividades sexuais (CACCIÒ e SPRONG, 2011).

Guerden e Olson (2011) descreveram o ciclo de vida de G. duodenalis. O ciclo de vida de G. duodenalis compreende dois estádios principais: o estádio trofozoíto, que coloniza o epitélio intestinal do hospedeiro e pode causar danos ao hospedeiro, e o estágio do cisto infeccioso, que é a forma de resistência no ambiente. Depois da ingestão, as paredes do cisto se rompem e os trofozoítos são liberados nas partes mais altas do intestino delgado. Para a colonização do intestino delgado, é essencial que ocorra adesão das células epiteliais por meio do disco adesivo do trofozoíto. Os trofozoitos se multiplicam por divisão binária no lúmen do intestino delgado. Por fim, a exposição a sais biliares leva a encistamento de trofozoítos, e os cistos formados já são imediatamente infecciosos. Os cistos são então eliminados pelas fezes, permitindo a conclusão do ciclo de vida em até 72 horas após a infecção.

Assim como no caso das espécies de Cryptosporidium, considera-se haver potencial de contaminação zoonótica por espécies de Giardia. Segundo Feng e Xiao (2011), existem estudos de caso-controle com grupos expostos ao contato com animais domésticos em fazendas e grupos de moradores de uma cidade abastecida por um sistema de tratamento com água filtrada e clorada. O primeiro grupo apresentou uma pequena prevalência dos sinais clínicos de giardiose enquanto não houve nenhum caso no segundo grupo.

\subsection{SURTOS DOCUMENTADOS DE GIARDIOSE E CRYPTOSPORIDIOSE}

O caso mais emblemático da literatura internacional é o ocorrido na cidade de Milwaukee, Winsconsin, Estados Unidos, em 1993. Neste surto, cerca de 400 mil pessoas foram acometidas por criptosporidiose (MACKENZIE et al., 1994). Segundo estes autores, a fonte das infecções foi uma falha operacional no sistema de tratamento de água. Neste episódio, nos dias que antecederam o surto, a turbidez da água tratada distribuída havia aumentado ao valor de $2,7 \mathrm{uT}$.

Em estudos mais recentes, 31 pessoas foram acometidas por giardiose em um sistema comunitário de abastecimento de água nos Estados Unidos em 2007 (DALY et al., 2010). Os afetados representavam $63 \%$ da população abastecida por um poço de água subterrânea, que fora apontado nesta pesquisa como fonte da contaminação. Neste caso, o poço utilizado para a 
captação não cumpria o afastamento mínimo de 15 metros, regulamentado pela legislação local.

Na Suécia, em novembro de 2010, aproximadamente 27 mil pessoas foram afetadas por um surto de criptosporidiose (WIDERSTROM et al., 2014). Neste evento, destacou-se o baixo valor de dose infectante da espécie de Cryptosporidium associada ao acontecimento. $\mathrm{Na}$ ocasião do surto, a concentração média de oocistos na rede de distribuição da água tratada era de 0,20 organismos para cada 10 litros de água. A caracterização molecular permitiu identificar a subespécie C. hominis IbA10G2 em fezes humanas e amostras ambientais e considerou-se que o surto fora provavelmente causado por contaminação de águas superficiais por esgotos domésticos. De acordo com os autores, a subespécie identificada é considerada altamente virulenta e está associada a outros surtos, incluindo o de Milwaukee.

Há ainda relatos de ocorrência de surto em sistema condominial. De maio a junho de 2012, em Seul, Coréia do Sul, ocorreram 124 casos de criptosporidiose em residentes de um antigo complexo de apartamentos (CHO et al., 2013). Este fora um surto atípico, uma vez que não houve responsabilidade do sistema de tratamento e distribuição de água. Segundo Cho et al.(2013), a água que era distribuída aos apartamentos ficava armazenada em um tanque subterrâneo e, na ocasião, fora continuamente contaminada por esgoto do tanque séptico do condomínio. O fato ocorreu porque o sistema de tubulação estava seriamente comprometido por conta de problemas de corrosão.

$\mathrm{Na}$ realidade brasileira existem informações disponíveis sobre ocorrência destes protozoários em mananciais (BARROS JUNIOR, 2011; BASTOS et al., 2003; BRANCO, 2006; CANTUSIO NETO et al., 2010; FRANCO et al., 2001; LOPES, 2009;) e sobre ocorrência em amostras clínicas de fezes em eventos diarreicos (FRANCO et al., 1996; GONÇALVES et al. 2006).

Franco et al. (1996) estudaram a prevalência de Giardia duodenalis e Cryptosporidium parvum em crianças atendidas em creches no município de Campinas, São Paulo. Oocistos de C. parvum e cistos de G. duodenalis foram detectados em $6,4 \%(n=20)$ e $13,5 \%(n=42)$ dos exames fecais das crianças, respectivamente, de forma que " $n$ " é o número de crianças infectadas, para cada patógeno. Evidenciou-se a importância da rota de contaminação pessoaa-pessoa, principalmente pela ocorrência destes protozoários em fezes de crianças na faixa etária de início do treinamento de higiene.

Gonçalves et al. (2006) investigaram, em nível molecular as espécies de Cryptosporidium presentes nas fezes de crianças que frequentavam uma creche mantida no 
Hospital das Clínicas, na cidade de São Paulo. As amostras foram coletadas de 224 crianças $(68,3 \%)$ no período de um surto de criptosporidiose ocorrido entre março e maio de 2001. Foram investigadas 29 amostras, positivas para oocistos de Cryptosporidium, por tecnologias moleculares. O estudo reforçou a hipótese da contaminação pessoa-a-pessoa pela rota fecal oral para este surto.

\subsection{Monitoramento DA OCORRÊNCIA DE CISTOS DE GIARDIA SPP. E OOCISTOS DE CRYPTOSPORIDIUM SPP. NO BRASIL}

Relatos científicos reportam a ocorrência cistos de espécies de Giardia e Cryptosporidium na realidade brasileira. A maioria dos estudos está concentrada na região sudeste, em especial no estado de São Paulo. Sato et al. (2013) realizaram um levantamento da ocorrência de (oo)cistos em nove bacias hidrográficas (fontes de captação de água para abastecimento no Estado de São Paulo). Espécies de Giardia e Cryptosporidium foram encontradas em 49,5\% e 9,2\% das amostras coletadas, respectivamente, com concentração máxima de 97 cistos de Giardia e 6 oocistos de Cryptosporidium por litro de amostra. Os autores indicam que a alta contaminação encontrada de cistos de Giardia é devida ao baixo nível de coleta e tratamento de esgotos em todas as regiões analisadas. O nível moderado de oocistos de Cryptosporidium também foi apontado como relevante, pois este patógeno possui características de alta virulência, infecciosidade e resistência ambiental.

Razzolini et al. (2011) investigaram a contaminação por Giardia de poços rasos utilizados para captação de água em área periurbana da cidade de São Paulo. Das 16 amostras tomadas para análise, 10 foram positivas para a presença de Giardia $(62,5 \%)$. A concentração máxima encontrada fora de 36,1 cistos por litro de amostra. O estudo demonstrou que os poços utilizados para captação estão vulneráveis à contaminação e ficou estabelecido um alerta às autoridades públicas quanto à ausência de distribuição de água tratada nestas áreas.

As águas do Rio Atibaia, em Campinas, São Paulo, também foram analisadas a respeito da ocorrência de Giardia e Cryptosporidium. Cantusio Neto et al. (2010) encontraram positividade de $87,5 \%$ das amostras para Giardia e 62,5\% para Cryptosporidium. Em Minas Gerias, na cidade de Viçosa, Dias et al. (2008) realizaram um levantamento, em 2003, e encontraram contaminação por (oo)cistos de Giardia e Cryptosporidium ao longo da bacia do rio utilizado como fonte de abastecimento, com provável influência da pecuária local.

Estas informações quanto à ocorrência de cistos de Giardia e oocistos de Cryptosporidium são importantes no sentido de evidenciar a necessidade de proteção dos 
corpos d'água (CANTUSIO NETO et al., 2010; DIAS et al. 2008), com balizamento de políticas públicas de ocupação do solo das bacias hidrográficas (DIAS et al., 2008). Além disso, são essenciais para condução do tratamento de águas captadas nesses mananciais (CANTUSIO NETO et al., 2010).

Dados a respeito da contaminação de águas pelos protozoários de estudo são complementados por Bastos et al. (2004), Bastos et al. (2009), Branco (2006), Franco, RochaEberhardt e Cantusio Neto (2001), Hachich et al. (2004), Machado et. al. (2009), Martins (2012).

\subsection{METODOLOGIAS PARA A IDENTIFICAÇÃo DE (OO)CISTOS DE PROTOZOÁRIOS}

Um dos motivos pelos quais a presença de (oo)cistos de Giardia e Cryptosporidium é considerada importante desafio no que se refere ao tratamento e distribuição de água é a complexidade metodológica para a identificação destes. A avaliação destes protozoários em águas naturais é difícil, as técnicas atuais ainda estão sujeitas à grande variabilidade e baixa reprodutibilidade, proporcionalmente ao aumento da turbidez, e representam um alto custo frente aos métodos usados para medir outras variáveis de qualidade da água (FRANCO, BRANCO e LEAL, 2012).

Os métodos de detecção de cistos e oocistos são fundamentados em três etapas: i) amostragem e concentração; ii) purificação; e iii) visualização e enumeração dos protozoários (FRANCO, BRANCO e LEAL, 2012).

\subsubsection{METOdOLOGIAS PARA A CONCENTRAÇÃo DE (OO)CISTOS}

Os métodos da etapa de concentração incluem: i) floculação em carbonato de cálcio (VESEY et al., 1993); ii) filtração em membranas de acetato de celulose de $142 \mathrm{~mm}$ e 1,2 $\mu \mathrm{m}$ de porosidade nominal (SHEPARD e WYN-JONES, 1995), de ésteres mistos de celulose de $47 \mathrm{~mm}$ e $3 \mu \mathrm{m}$ de porosidade nominal (FRANCO, ROCHA-EBERHARDT E CANTUSIO NETO, 2001); e iii) filtração em kits comerciais, Envirocheck ${ }^{\circledR}$ e Filta-Max ${ }^{\circledR}$, validados pelo Métodos USEPA 1623.1 (USEPA, 2012).

O método da floculação em carbonato de cálcio (VESEY et al., 1993) consiste na adição e mistura de cloreto de cálcio e bicarbonato de sódio à amostra contendo protozoários. $\mathrm{O}$ pH é elevado até 10 com adição de hidróxido de sódio. A amostra é mantida em temperatura ambiente por período overnight para então o sobrenadante ser cuidadosamente removido. O precipitado é dissolvido com solução de ácido sulfâmico, A mistura é 
centrifugada e o sedimento é submetido a uma nova centrifugação e então, deste pellet final, retira-se alíquotas para análise em microscopia, ou submete-se para a etapa de purificação, caso esta seja executada (CANTUSIO NETO et al., 2010).

Cantusio Neto et al. (2010) encontraram baixa recuperação para o método da floculação em carbonato de cálcio em água reagente ( inferior a 10\% de recuperação para Giardia e Cryptosporidium na presença e ausência de etapa de purificação). Para água matriz, os mesmos pesquisadores encontraram moderada recuperação. Segundo Franco, Branco e Leal (2012), o método apresenta uma série de limitações:, i) pode ocorrer perda de organismos no sobrenadante; ii) depende das características da centrifugação; iii) o sedimento é rico em material particulado, propiciando a ocorrência de resultados falso-positivos; iv) o $\mathrm{pH}$ requerido para floculação pode causar alterações morfológicas nos protozoários, levando resultados falso-negativos ou interferências em ensaios de infecciosidade.

No método da filtração em membranas, Aldom e Chagla (1995) utilizaram membranas de acetato de celulose com 1,2 $\mu \mathrm{m}$ de porosidade. A dissolução do material filtrado era realizada com acetona em tubo cônico com posterior centrifugação. Franco, Rocha-Eberhardt e Cantusio Neto (2001) consideraram o uso de membranas de ésteres mistos de celulose de 47 $\mathrm{mm}$ de diâmetro e porosidade nominal de $3 \mu \mathrm{m}$ na filtração à vácuo. Neste método, o material filtrado é, alternativamente, raspado cuidadosamente com alça plástica macia e lavado com solução de eluição. O líquido resultante é então centrifugado do sedimento final de $1 \mathrm{~mL}$, retirando-se alíquotas $(10 \mu \mathrm{L})$ para o exame de microscopia.

A filtração em membranas é limitada pelo efeito de turbidez da água, o que pode causar rápida obstrução dos poros da membrana, havendo necessidade da substituição destas (FRANCO, BRANCO e LEAL, 2012). Segundo Vesey e Slade (1990) ${ }^{2}$ apud Vesey et al. (1993) na filtração por membranas pode ocorrer perdas quando os oocistos passarem pelos filtros ou quando eles se aderirem ao material filtrante, não sendo recuperados. Como vantagens, essa metodologia tem custo menor e muitos laboratórios (Laboratórios Centrais de Saúde Públicas - Lacen; e empresas de saneamento) já contam com a infraestrutura (equipamentos de filtração) necessária para esse procedimento (FRANCO, BRANCO e

${ }^{2}$ VESEY, G.;SLADE, J.S. (1990) Isolation and identification of Cryptosporidium from water. Water Science and Technology 24, 165-167 
LEAL, 2012). Franco, Branco e Leal (2012) ainda destacam maior praticidade do método, já que requer volumes menores (a partir de um litro) quando comparados a sistemas como o Filta-Max ${ }^{\circledR}$.

A filtração com o Sistema Filta-Max ${ }^{\circledR}$ é aceita pelo Método 1623.1 (USEPA, 2012). Basicamente a amostra é filtrada em capsulas de filtração, depois, a espuma filtrante é retirada da capsula, acondicionada em saco plástico e lavada com solução tampão de fosfato contendo Tween 80 e, posteriormente, é comprimida. O líquido resultante é centrifugado.

É importante destacar que o sistema Filta-Max ${ }^{\circledR}$ pode apresentar alta sensibilidade para detecção de protozoários no caso da filtração de grandes volumes. Razzolini, Santos e Bastos (2010) concentraram 12 amostras de 400 litros de água tratada e encontraram cistos de Giardia e oocistos de Cryptosporidium em 41,7\% e 7,6\% das amostras, respectivamente. Observa-se que só foi possível identificar estes organismos nestas amostras pela alta sensibilidade do método.

A principal limitação da metodologia com Filta-Max ${ }^{\circledR}$ é o alto custo. Além disso, o método envolve maior complexidade laboratorial, exige recursos humanos especializados, sofre influência da turbidez da amostra. O método ainda apresenta problemas com amostras ricas em ferro, matéria orgânica e com a presença de óleos, graxas e grande quantidade de material em suspensão (FRANCO, BRANCO e LEAL, 2012).

\subsubsection{PURIFICAÇão DE (OO)Cistos}

O processo de concentração de cistos de Giardia e oocistos de Cryptosporidium leva à acumulação de sólidos nos sedimentos das amostras resultantes das etapas de centrifugação. A detecção precisa dos (oo)cistos requer processos de purificação da amostra, para separá-los dos demais sólidos (CLANCY et al., 2000).

A purificação de amostras pode ser feita pelo processo de flutuação (em sacarose, por exemplo) ou por separação imunomagnética. Segundo Clancy et al.(2000), o processo de purificação por flutuação pode isolar, junto aos (oo)cistos, grande quantidade de material particulado e células de algas, que interferem na detecção por microscopia, o que limita a quantidade de material a ser examinado microscopicamente. Além disso, o método apresenta grande variabilidade de recuperação, por exemplo, Bukhari e Smith (1995) encontraram recuperação de 24 a 65\% para oocistos de Cryptosporidium purificados por flutuação em sacarose. Segundo estes autores, o efeito da purificação pode ser dependente da viabilidade dos oocistos, neste caso, a maioria dos oocistos observados era não viável após a purificação.. 
A metodologia de purificação, componente do Método 1623.1 (USEPA, 2012), é a separação imunomagnética - IMS. A tecnologia de IMS é relativamente recente e emergiu como a mais eficiente para recuperação específica de cistos de Giardia e oocistos de Cryptosporidium (CLANCY et al., 2000). Existem alguns kits comerciais disponíveis para este procedimento, no entanto, o Método 1623.1 reconhece apenas o kit Dynabeads® ${ }^{\circledR}$ GC Combo. Os kits utilizam anticorpos monoclonais específicos para Giardia e Cryptosporidium conjugados com esferas magnéticas de tamanho pré-definido ( 0,8 a 4,5 $\mu \mathrm{m}$ ) (CLANCY et al., 2000).

No método de IMS, as amostras contendo cistos e oocistos são mantidas sob agitação com a solução de anticorpos monoclonais específicos conjugados a esferas magnéticas para que haja captura dos organismos alvos. Posteriormente, os organismos aderidos aos complexos de esferas são separados magneticamente do restante da amostra. Segundo Clancy et al. (2000), a suspensão em ácido é capaz de romper o complexo de esfera magnética conjugada aos organismos, que é formado como resultado da ligação de anticorpos com epítopo dos antígenos das paredes externas dos organismos.

Uma avaliação sobre o desempenho de kits comerciais para IMS foi realizada por Bukhari et al. (1998). Nesta pesquisa, o desempenho para purificação de oocistos de Cryptosporidum do kit Dynabeads ${ }^{\circledR}$ Combo (DB) foi comparado ao Crypto-Scan ${ }^{\circledR}$ IMS (IC1) e Crypto-Scan ${ }^{\circledR}$ IMS modificado (IC-2). Em água deionizada, o DB apresentou alta recuperação e baixa variabilidade, enquanto IC-1 e IC-2 apresentaram alta variabilidade. Já em águas com elevada turbidez, o DB apresentou alta recuperação com maiores variabilidades, enquanto os teste IC-1 e IC-2 apresentaram recuperação máxima de 8,3\% em uma amostra com turbidez de $50 \mathrm{uT}$. Os autores argumentam que o kit DB é capaz de separar amostras com volume de pellet superior a $0,5 \mathrm{~mL}$ enquanto IC-1 tem queda drástica de desempenho para análise deste volume.

\subsubsection{DETECÇÃo DE (OO)CISTOS}

Os métodos de detecção de cistos de Giardia e oocistos de Cryptosporidium são muitos, e variam desde os mais básicos, envolvendo a suspensão de organismos em lâminas de vidro para exame em microscopia no campo claro, até métodos mais complexos, baseados em biologia molecular (CLANCY, et al. 2000).

$\mathrm{O}$ desenvolvimento de técnicas de detecção baseadas em reagentes com anticorpos monoclonais específicos (GARCIA, SHUM e BRUCKNER, 1992) aumentou a confiabilidade 
nos procedimentos de identificação de protozoários. Estas técnicas se baseiam na identificação de (oo)cistos marcados com corantes fluorescentes na microscopia de fluorescência. Os parátopos dos anticorpos se ligam aos epítopos dos antígenos da superfície exposta dos (oo)cistos, a visualização em fluorescência define as máximas dimensões do organismo, o que permite a realização de análises morfológicas (SMITH e GRIMASON, 2003). Esta análise é altamente específica, o que diminui a ocorrência de falsos-positivos e falsos-negativos (GARCIA, SHUM E BRUCKNER, 1992).

O Método 1623.1 estabelece, na etapa de detecção, a adição de anticorpos monoclonais conjugados ao fluorocromo FITC (isotiocianato de fluoresceína) e teste confirmatório da morfologia empregando a coloração com DAPI (4',6-diamino-2fenil-indol). Este método aprovou 4 kits comerciais para esta etapa: i) Merifluor ${ }^{\circledR}$ - Meridian Diagnosis; ii) Aqua-Glo ${ }^{\mathrm{TM}}$ - Waterborne; iii) Crypto-a-Glo ${ }^{\mathrm{TM}}$ e Giardia-a-Glo ${ }^{\mathrm{TM}}$; iv) EasyStain ${ }^{\mathrm{TM}}-\mathrm{C} \& \mathrm{G}$.

Ainda que haja alta especificidade na análise de microscopia de fluorescência, por infortúnio, os anticorpos monoclonais disponíveis demonstram reatividade cruzada, o que pode levar a resultados falsos-positivos como leveduras e algas de tamanho semelhante (CLANCY et al., 2000). Como uma alternativa auxiliar a este problema, a adição de DAPI tem sido utilizada para destacar os núcleos dos (oo)cistos. A visualização de até 4 núcleos em cor azul pode prover informações suficientes para detectar e identificar oocistos (GRIMASON et al., 1994). Neste estudo, foi encontrada excelente correlação entre fluorescência do núcleo dos esporozoítos após coloração com DAPI e visualização de oocistos esporulados em microscopia DIC (microscopia de contraste interferencial diferencial).

No entanto, o uso combinado de anticorpos monoclonais e DAPI ainda apresenta limitações. A análise de DAPI só é útil quando o (oo)cisto apresenta núcleos (SMITH e GRIMASON, 2003). A coloração do núcleo com DAPI ainda pode falhar por conta de impermeabilidade do organismo (CLANCY et al., 2000). Diante disso, o Método 1623.1 ainda requer análise complementar em microscopia DIC, que possibilita a identificação de estruturas internas.

O conjunto de análises descrito possibilita avaliação quantitativa e qualitativa dos (oo)cistos, entretanto, não há possibilidade da identificação de espécies. Em uma situação de surto, é interesse a investigação dos genótipos envolvidos. O método de biologia molecular de Reação em Cadeia da Polimerase (Polymerase Chain Reaction - PCR) possibilita a caracterização genotípica dos (oo)cistos. Este método produz múltiplas cópias do DNA alvo. 
Os equipamentos geram sequenciamentos que podem ser comparados com base de dados. $\mathrm{O}$ método é rápido, acurado e altamente sensível, porém, é também sujeito a limitações como a exposição dos ácidos nucleicos após rompimento da membrana celular, organismos não viáveis e sensibilidade à contaminação (TOZE, 1999).

\subsection{REMOÇÃo DE (OO)CISTOS POR TÉCNICAS DE TRATAMENTO DE ÁGUA}

\subsubsection{COAGULAÇÃO E DECANTAÇÃo}

Cistos de Giardia spp. e oocistos de Cryptosporidium spp., quando presentes nas águas naturais, possuem velocidade de sedimentação em torno de $0,67 \mu \mathrm{m} . \mathrm{s}^{-1}$ e $0,27 \mu \mathrm{m} . \mathrm{s}^{-1}$, respectivamente (DAI e BOLL, 2006). Estas são velocidades extremamente baixas para que ocorra a separação destes patógenos na decantação. Desta forma, a coagulação seguida da floculação, quando bem sucedidas, são fundamentais para o êxito do sistema quanto à remoção de (oo)cistos de protozoários no tratamento por ciclo completo ou, também, chamado de tratamento convencional (coagulação, floculação, decantação e filtração).

A maior parte dos trabalhos científicos a respeito da remoção de (oo)cistos de protozoários no tratamento de água concentra-se na otimização de processos e operações para o tratamento de oocistos de Cryptosporidium spp. Segundo Betancourt e Rose (2004), estes organismos são mais resistentes à remoção e inativação pelos processos e operações presentes no tratamento convencional, quando comparados aos cistos de Giardia spp.

A remoção de Cryptosporidium spp. em todas as etapas do tratamento convencional é fortemente influenciada pela eficácia do pré-tratamento por coagulação (DUGAN et al., 2001). Neste sentido, a escolha do coagulante e o controle de sua operação são determinantes no tratamento de águas contendo protozoários. Segundo Dugan et al.(2001), a mudança da coagulação de sub-ótima para ótima ou melhorada resultou em aumento na remoção de oocistos de Cryptosporidium, muito mais significativo que melhoras na remoção de variáveis alternativas de controle, tais como: turbidez, esporos de bactérias aeróbias e contagem total de partículas.

Bustamante et al. (2001) estudaram a interação entre coagulantes utilizados no tratamento de água e oocistos de Cryptosporidium spp. Os resultados desta pesquisa indicam que quando o cloreto férrico foi empregado como coagulante, com dosagem de $3,3 \mathrm{mg} . \mathrm{L}^{-1}$, não houve mudanças no potencial zeta dos oocistos. Os autores indicam que este efeito é 
diferente do que se reporta na ação deste coagulante sobre a sílica e os minerais de argilas coloidais ( adsorção de ferro nessas superfícies com consequente reversão do potencial zeta das partículas). A interação com coagulantes a base de alumínio, por outro lado, acontece de maneira diferente.

Segundo Bustamante et al. (2001) ocorreu reversão de carga dos oocistos quando se utilizaram espécies de alumínio como coagulante. Nesse experimento, a coagulação ocorreu com dosagem de $6,8 \mathrm{mg} . \mathrm{L}^{-1}$ de alumínio. Espécies hidrolisadas de alumínio foram adsorvidas na superfície dos oocistos, isso causou a reversão do potencial zeta destes, que passa de negativo para positivo. Provavelmente ocorre uma forte ligação com esta interação específica, que pode ser fator determinante na capacidade dos flocos de alumínio com oocistos, remanescentes após decantação, serem retidos no leito filtrante de ETAs.

Por outro lado, Butkus, Bays e Labare (2003) indicam que nem sempre os oocistos de Cryptosporidium spp. apresentam carga superficial e que esta estabilidade pode dificultar a remoção por processos típicos de tratamento de água. Este fato indica que o mecanismo de coagulação por varredura seria o predominante na remoção dos oocistos.

Em estudo com Cryptosporidium e matéria orgânica natural inoculados em água sintética, Xagoraraki e Harrington (2004) relataram que o mecanismo de neutralização não foi um fator importante na remoção de oocistos. Neste estudo, foram avaliadas várias dosagens de alumínio, que variou de $1 \mathrm{mg} \cdot \mathrm{L}^{-1}$ a $100 \mathrm{mg} \cdot \mathrm{L}^{-1}$. A remoção foi avaliada em experimentos de coagulação, floculação e sedimentação, em escala de bancada. As melhores remoções de oocistos foram observadas em combinações de valor de $\mathrm{pH}$ de coagulação e dosagem de alumínio identificados como correspondentes à coagulação por varredura. Segundo os autores, é possível que a matéria orgânica natural atue como agente de colmatação entre a superfície de oocistos e a superfície dos flocos de hidróxido de alumínio.

States e Tomko (2002) estudaram o efeito da coagulação melhorada na remoção de oocistos de Cryptosporidium spp. Os resultados desta pesquisa indicaram que a diminuição no valor do pH de coagulação não implicou em piora no desempenho da remoção de oocistos de Cryptosporidium spp., para a coagulação com cloreto férrico $\left(18 \mathrm{mg} \cdot \mathrm{L}^{-1}\right)$, cloreto de polialumínio $\left(27,5 \mathrm{mg} . \mathrm{L}^{-1}\right)$ e sulfato de alumínio $\left(17 \mathrm{mg} . \mathrm{L}^{-1}\right)$. Apenas este último apresentou menor remoção em pH 5. Neste estudo, simulou-se o tratamento convencional em escala piloto, com coagulação seguida de floculação, sedimentação e filtração. Já Fernandes et al. (2010) encontraram melhor eficiência na remoção destes protozoários em pH de coagulação em torno de 5, utilizando sulfato de alumínio. Os experimentos foram realizados com filtração 
direta em escala piloto. Estes autores sugerem que, nestas condições, a hidrofobicidade dos oocistos foi favorecida e a repulsão entre os mesmos diminuiu nessa faixa de melhores resultados.

Quanto à etapa de sedimentação, ainda há certa lacuna de informações na literatura quanto ao seu desempenho (LeChevallier, 2004; Smith e Grimason 2003). Smith e Grimason (2003) indicaram remoção esperada de $1 \log _{10}$ de (oo)cistos em águas cujo tratamento tenha sido realizado em adequadas condições de coagulação e floculação. No experimento de Silva (2008), em escala piloto, houve remoção de $2,03 \log _{10}$ e $1,76 \log _{10}$ de oocisto de Cryptosporidium spp., utilizando sulfato de alumínio como coagulante, em decantador convencional e de alta taxa, respectivamente. Neste experimento, considerou-se uma água de estudo com turbidez de $100 \pm 5 \mathrm{uT}$.

O processo de clarificação alternativo à sedimentação, a flotação por ar dissolvido, tem se mostrado efetivo quanto à remoção de (oo)cistos de protozoários. O desempenho pode atingir 2 a $3 \log _{10}$ de remoção de oocistos de Cryptosporidium spp. (Edzwald, 2010).

\subsubsection{REMOÇÃO EM MEIOS FILTRANTES}

$\mathrm{Na}$ literatura científica, reporta-se mais comumente estudos do desempenho de tratamentos envolvendo a filtração como processo final para a remoção de (oo)cistos de protozoários (EMELKO, 2003; HSU, 2003; SWERTFEGER et al. 1999).

A respeito das condições de filtração, Hsu, Huang e Pan (2001) encontraram uma relação inversa entre o valor do pH de operação e a eficiência de colisão entre os (oo)cistos e o meio filtrante. Segundo os autores, este comportamento pode ser explicado pelo efeito do $\mathrm{pH}$ no potencial zeta da superfície do meio filtrante. Dessa forma, aumenta-se o efeito repulsivo entre partículas e coletores com o aumento do pH. Segundo Hsu e Huang (2002), o potencial zeta dos (oo)cistos torna-se menos eletronegativo com a diminuição do $\mathrm{pH}$ do meio.

Segundo Emelko (2003), a eficiência de remoção no filtro é extremamente dependente da etapa de coagulação. Neste estudo, a falha na coagulação resultou em uma eficiência de remoção de oocistos de Cryptosporidium parvum da ordem de $3 \log _{10}$ menor em relação à condição otimizada de coagulação. De acordo com a autora, mesmo condições não ideais de coagulação podem atingir turbidez efluente ao filtro na ordem de 0,3 uT, no entanto, a remoção de C. parvum é deteriorada nessas condições. States e Tomko (2002) também apontaram que a turbidez não é uma variável confiável para indicar remoção de 
Cryptosporidium. Dugan (2001) obteve remoção total de Cryptosporidium sempre maior que $4 \log _{10}$ em condições ótimas de coagulação.

O mecanismo atuante no processo de filtração foi estudado por Tufenkji (2004). Neste estudo, avaliou-se o transporte de oocistos de Cryptosporidium em areia de quartzo. Foram realizados ensaios em diferentes condições de força iônica. O valor do potencial zeta do oocisto e da areia se tornavam menos eletronegativos com o aumento da força iônica. Os resultados deste estudo indicaram que houve deposição significativa de oocistos nas areias de quartzo mesmo em condição de baixa força iônica (potencial zeta mais eletronegativo). Neste sentido, houve predominância de mecanismos físicos de remoção, como a ação de coar, que não são influenciados por interações eletrostáticas. Uma explicação para este resultado é a irregularidade na forma dos grãos de areia.

Hijnen et al. (2010) avaliaram o desempenho do carvão ativado granular (GACGlanular Activeted Carbon) na remoção de patógenos, dentre eles (oo)cistos de protozoários. Neste estudo, os mecanismos físicos de remoção dos (oo)cistos para este meio filtrante apresentaram menor importância quando comparados aos mecanismos de aderência. Os resultados foram promissores para a remoção de (oo)cistos de protozoários, variando de 1,3 a 2,7 $\log _{10}$ nas condições estudas.

Papineau et al. (2013) estudaram o efeito do amadurecimento de três meios filtrantes granulares na remoção de C. parvum: areia, antracito e GAC. O amadurecimento do meio filtrante promoveu melhor desempenho no tratamento para a areia e o GAC. Os experimentos foram realizados mediante condições de favorecimento do crescimento de biofilme antes do tratamento da água com oocistos. Neste caso, houve aumento da retenção de oocistos provocada pelo desenvolvimento do biofilme, que pode ter ocasionado stress no meio. Além disso, o biofilme formado reduz o potencial zeta do meio filtrante, o que aumenta a sua capacidade de retenção. O amadurecimento do filtro apresentou efeito mais notadamente positivo na remoção de oocistos para o meio filtrante composto por GAC.

\subsubsection{INATIVAÇÃo}

Quanto à inativação de protozoários, a resistência de Cryptosporidium a agentes de desinfecção como o cloro é uma das principais razões pelas quais este patógeno tem sido considerado um grande problema para o tratamento de água (MONIS, KING e KEEGAN, 2014). A literatura indica que os cistos de Giardia são mais sensíveis à ação de desinfetantes, quando comparados aos oocistos de Cryptosporidium. Na pesquisa de Widmer et al.(2002), 
ao se utilizar uma concentração de $1,5 \mathrm{mg} . \mathrm{L}^{-1}$ de ozônio foram necessários 60 segundos para destruição da parede dos cistos.

Korich et al. (1990) estudaram (em escala de laboratório) o desempenho dos seguintes agentes oxidantes na infecciosidade do C. parvum: ozônio, dióxido de cloro, cloro e cloramina. Os resultados deste trabalho indicaram que, ao se utilizar o mesmo fator de concentração de desinfetante multiplicado pelo tempo de contato - $C t$, o cloro possui um poder de desinfecção 30 e 14 vezes menor que o ozônio e o dióxido de cloro, respectivamente.

No estudo de Wohlsen et al. (2007), realizou-se a aplicação de ozônio em uma concentração de $2,5 \mathrm{mg} . \mathrm{L}^{-1}$ e tempo de $10 \mathrm{~min}$ para inativação de oocistos de Cryptosporidium. Houve inativação imediata de $49 \%\left(0,29 \log _{10}\right)$ dos oocistos à temperatura de $24^{\circ} \mathrm{C}$ e $57 \%\left(0,37 \log _{10}\right)$ a $18,9^{\circ} \mathrm{C}$. Ainda, depois de 10 minutos, inativação de $90 \%$ (1 $\left.\log _{10}\right)$ e $92 \%\left(1,1 \log _{10}\right)$ para as mesmas condições de temperatura, respectivamente. Este estudo foi realizado em escala real, nestas condições, o ozônio se decompõe em oxigênio rapidamente após sua geração (USEPA, 1999).

Ran et al. (2010) encontraram correlação positiva entre eficiência de inativação de Cryptosporidium e turbidez da água em experimento com ozônio. Além disso, a ação oxidante foi mais favorecida em condições ácidas em comparação à alcalinas. Os experimentos apresentaram os melhores resultados sob a concentração de ozônio de 3,0 mg.L $\mathrm{L}^{-1}$, decorrido 7 minutos de contato. A análise morfológica dos oocistos mostrou que, sob o tempo de contato de 60 segundos, as paredes dos oocistos apresentavam dobras, já em 480 segundos, observouse completa destruição das paredes.

Para o tratamento de água, interessa a avaliação da infecciosidade dos (oo)cistos. A avaliação mais confiável desta é por meio de ensaios de infecciosidade com modelos animais. Métodos de viabilidade com corante vital foram desenvolvidos como alternativas a estes ensaios e são vistos como mais convenientes que a excistação in vitro (Bukhari et al., 2000). Alguns desses métodos consideram a indicação de viabilidade como mudanças na permeabilidade da membrana ou determinadas respostas dos oocistos aos estímulos biológicos (Bukhari et al.,2000). Estas diferenças têm causado confusão quanto ao significado de resultados de diversas análises de viabilidade (Bukhari et al., 2000). 


\subsection{Ensaios de Tratabilidade da ÁGuA}

Segundo Libânio (2008), os ensaios de tratabilidade visam definir as dosagens dos produtos químicos e o $\mathrm{pH}$ mais adequados à elevação da qualidade do efluente em uma estação de tratamento de água. No entanto, esses ensaios também possibilitam definir os principais parâmetros de projeto nas etapas de mistura rápida, floculação, decantação e filtração, além de permitir, entre outros aspectos, avaliar os resíduos gerados. Embora a qualidade dos resultados dos ensaios de tratabilidade cresça com o emprego de unidadespiloto, os maiores custos da instalação as tornam muito raramente utilizadas mesmo em países desenvolvidos - quando o são, destina-se quase que exclusivamente às estações de grande porte. Desta forma, esses ensaios comumente são realizados em reatores estáticos.

O tradicional ensaio em Jarteste é fundamental para determinar os parâmetros de projetos de tecnologias com coagulação química. O Jarteste é constituído de seis jarros, paletas de agitação, motor com rotação controlada, tacômetro digital com visor mostrando a rotação das paletas e controles para ajuste da rotação. Para simular o tratamento por ciclo completo autores como De Julio et al. (2009) utilizaram kit de filtros de laboratório em conjunto com o Jarteste. A metodologia do ensaio em Jarteste é apresentada, em detalhes, em Di Bernardo et al (2011).

\subsection{Emprego de Cloreto de Polialumínio como Coagulante}

A escolha do coagulante é um fator que influencia a eficiência do tratamento considerando suas características e dosagens empregadas. Nas ultimas décadas têm sido desenvolvidos diversos polímeros inorgânicos produzidos a partir de cloretos e sulfatos, os quais recebem diversas denominações, tais como: cloreto de polialumínio, sulfato poliférrico e sulfato polialumínio-ferro. No Brasil, o mais comum é o hidroxicloreto de alumínio, ou cloreto de polialumínio - PAC, fornecido em pó ou em solução.

Os compostos poliméricos inorgânicos são denominados coagulantes de segunda geração. Segundo Ferreira Filho e Waelkens (2009), os compostos poliméricos formados a partir do alumínio como matéria prima são mais estáveis que aqueles produzidos a partir de sais de ferro.

O processo de fabricação do PAC é semelhante ao do sulfato de alumínio, ambos são produzidos a partir da bauxita $\left(\mathrm{Al}_{2} \mathrm{O}_{3}\right)$. A diferença é que durante o processo de produção do PAC ocorre adição de uma base forte, assim, com a presença de íons $\mathrm{OH}^{-}$, espécies 
monoméricas e poliméricas passam a ocorrer diretamente na solução de coagulante, ao invés de somente na fase líquida (FERREIRA FILHO e WALKENS, 2009). O PAC, desta maneira, apresenta maior estabilidade das formas hidrolisadas. Este aspecto o torna mais efetivo para a desestabilização das partículas, o que favorece a agregação destas em menor tempo, isso possibilita a obtenção da mesma qualidade da água com menor dosagem de coagulante quando o PAC é comparado ao sulfato de alumínio (DI BERNARDO et al., 2003).

O PAC, na maioria dos casos, revela-se como coagulante superior ao sulfato de alumínio em termos de eficiência. Para a eliminação de substâncias coloidais, sua eficácia é superior, em média, 1,5 a 2,5 vezes em igualdade de dosagem, em íon $\mathrm{Al}^{3+}$, à dos outros sais de alumínio (PAVANELLI, 2001). Destaca-se que o PAC apresenta vantagens em relação aos demais coagulantes, principalmente pela maior concentração de elemento ativo $-\mathrm{Al}_{2} \mathrm{O}_{3}$ (LOPES et al. 2009).

Ferreira Filho e Waelkens (2009b) argumentam a possibilidade de o PAC apresentar uma menor capacidade de produção de lodo em comparação aos coagulantes tradicionalmente empregados no tratamento de águas de abastecimento. Existe ainda a vantagem da eventual não necessidade de pré-alcalinização quando o coagulante é empregado (FERREIRA FILHO E WALKENS, 2009).

Dalsasso e Senz (2006) compararamo sulfato de alumínio e o PAC na tecnologia de filtração direta em águas com elevada concentração de fitoplâncton. O estudo apresentou como vantagem o uso do PAC em uma maior faixa de $\mathrm{pH}$ de coagulação quando comparado ao sulfato de alumínio (muito importante para filtração direta, onde qualquer distúrbio nesta etapa pode representar queda na qualidade da água filtrada). Além disso, a concentração de alumínio na água filtrada esteve abaixo do número mínimo detectável com o uso do PAC, o que não ocorreu com sulfato de alumínio. 


\section{MATERIAIS E MÉTODOS}

Para desenvolver as atividades foi utilizada a infraestrutura existente nos Laboratórios LATAR e Saneamento do SHS/EESC/USP. A pesquisa foi realizada nas etapas sequenciais descritas a seguir.

Etapa 1 - Realização de ensaios de tratabilidade: vários ensaios em Jarteste foram realizados na água de estudo. O critério de seleção dos "pontos ótimos" (dosagem de coagulante versus $\mathrm{pH}$ de coagulação) nos diagramas de coagulação foi a maior eficiência na remoção de turbidez (com e sem adição de alcalinizante ou acidificante). Os ensaios foram realizados para diferentes condições de mistura (gradiente e tempo), de velocidades de sedimentação e de taxas de filtração.

Etapa 2 - Realização do controle de qualidade do método de identificação de protozoários: o método de filtração em membranas de ésteres mistos de celulose de Franco et al., (2001) foi avaliada por meio de ensaios com inóculos (EasySeed ${ }^{\circledR}$ e ColorSeed ${ }^{\circledR}$ da BTF-BIO) de cistos de Giardia spp. e oocistos de Cryptosporidium spp. nas águas de estudo e reagente. $\mathrm{O}$ intuito dos ensaios foi averiguar a recuperação dos mesmos conforme os padrões estabelecidos pelo Método 1623.1 (USEPA, 2012).

Etapa 3 - Avaliação do desempenho do tratamento, em escala de bancada, na remoção de (oo)cistos: a partir dos "pontos ótimos" definidos na Etapa 1, vários ensaios foram realizados afim de se atestar o desempenho do sistema de tratamento proposto (coagulação, floculação, decantação e filtração) em escala de bancada. Uma estimativa na remoção de protozoários, em cada fase do tratamento, foi analisada conforme o protocolo indicado na Etapa 2.

A seguir são descritas as atividades previstas nas três etapas supracitadas.

\subsection{Preparação da ÁGua de estudo}

A água de estudo foi preparada com água do poço da EESC/USP e a turbidez foi aumentada com o uso de caulinita. Foram consideradas duas metodologias para a obtenção de água com a turbidez desejada: i) preparação de uma suspensão “mãe”, com pré-decantação de água matriz; e ii) aplicação direta da caulinita na água. 


\subsubsection{PREPARAÇÃo da ÁGUA de ESTUdo COM PRÉ-DECANTAÇÃo}

Inicialmente, buscou-se a utilização da metodologia descrita em Di Bernardo (2004) para a preparação da água de estudo.

A autora supracitada considerou o emprego de uma suspensão "mãe" para preparar a água de estudo. A suspensão era obtida pela mistura de caulinita com água poço. Posteriormente, a solução foi colocada em Cone Imhoff. Quantificava-se o material que sedimentava (sólidos sedimentáveis $-\mathrm{mL} . \mathrm{L}^{-1}$ ), pela força da gravidade, a partir de um 1,0 litro de amostra em repouso no Cone, em função do tempo. O ensaio era finalizado quando a concentração de sólidos sedimentáveis $\left(\mathrm{mL} \mathrm{L}^{-1}\right)$ permanecia constante com geração de sobrenadante de turbidez estável. O sobrenadante era, então, utilizado para preparar a água de estudo.

O ensaio foi realizado conforme descrito por Di Bernardo (2004). Primeiramente, foram pesados 21,5g da caulinita e adicionados em 1,0 L de água do poço da EES/USP. Após 2 horas de agitação, em jarteste, com gradiente de velocidade médio da ordem de $200 \mathrm{~s}^{-1}$, a suspensão foi transferida para o Cone Imhoff. Posteriormente, medidas de turbidez foram realizadas e o volume de sedimento $\left(\mathrm{mL} . \mathrm{L}^{-1}\right)$ foi quantificado em função do tempo.

\subsubsection{PREPARAÇÃo dA ÁGUA dE ESTUdo COM APLICAÇÃO DIRETA DE CAULINITA}

Um ensaio foi realizado com o objetivo de se estimar uma relação de massa de caulinita por volume de água de estudo para que a turbidez desejada fosse atingida. Aos jarros do aparelho de jarteste, foram adicionadas 3 diferentes porções de massa de caulinita $(0,8 \mathrm{~g} ; 0,4$ g e $0,2 \mathrm{~g}$ ), previamente pesadas em balança analítica. Os jarros foram mantidos sob agitação de $200 \mathrm{rpm}$ durante 2 horas. Após este período, realizou-se a leitura dos valores de turbidez das misturas de cada jarro.

\subsection{ENSAIOS DE TRATABILIDADE DA ÁGUA DE ESTUDO}

Os ensaios foram realizados em equipamento de Jarteste segundo metodologia de Di Bernardo et al., (2011) - ensaios específicos em ciclo completo com sedimentação. O intuito foi realizar os ensaios de coagulação, floculação e sedimentação para a construção dos diagramas de coagulação. O coagulante empregado foi o cloreto de polialumínio - PAC.

O PAC utilizado nos ensaios foi fornecido pela empresa Tiosertec ${ }^{\circledR}$ e possuía as seguintes especificações: basicidade 38,7 ; teor de alumínio de $17,74 \%$ na forma de $\mathrm{Al}_{2} \mathrm{O}_{3}$; $\mathrm{pH}$ 
da solução variando de 2,0 a 4,0; fórmula química $\mathrm{Al}_{\mathrm{n}}(\mathrm{OH})_{\mathrm{m}}\left(\mathrm{Cl}_{3}\right)_{\mathrm{n}-\mathrm{m}}$. O produto fora enviado por empresa especializada em 3 ocasiões, de forma que todos os experimentos da pesquisa se realizaram com o coagulante dentro do prazo de validade.

De posse dos diagramas de coagulação, dois pontos "ótimos" foram selecionados correspondendo a uma dosagem do coagulante e seu pH de coagulação (com e sem adição de alcalinizante ou acidificante). Os diagramas foram construídos apenas para turbidez por ser esta uma variável de rápida medição.

Para a filtração foi empregado kit de filtros de laboratório de areia - FLAs, conforme recomendações de granulometria (tamanho dos grãos 0,30 a $0,59 \mathrm{~mm}$ e tamanho efetivo de 0,42 mm) e de controle de taxa de filtração indicadas por Di Bernardo et al (2011).

Destaca-se que os FLAs são colunas de acrílico de $19 \mathrm{~mm}$ diâmetro interno com $40 \mathrm{~cm}$ de altura, sendo $15 \mathrm{~cm}$ preenchidos com areia. No estudo, a areia foi peneirada visando obter a granulometria desejada. A areia selecionada foi lavada da seguinte forma: uma porção de areia era colocada em um béquer de 2L (a areia preenchia a marca de $200 \mathrm{~mL}$ do béquer); ii) à areia era adicionada água da torneira até a marca de $1,0 \mathrm{~L}$; iii) a mistura era agitada por $30 \mathrm{~s}$, posteriormente, deixava-se em repouso por $2 \mathrm{~min}$; iv) o sobrenadante era descartado; v) o procedimento era repetido visando gerar um sobrenadante visualmente límpido; e vi) a areia era secada, em estufa, por 24 horas.

A areia, após secagem na estufa, era utilizada para o preenchimento dos filtros. A areia era colocada lentamente para não gerar bolsões de ar no meio filtrante. Após o preenchimento, a lavagem ascendente dos filtros era realizada, por meio de uma seringa, conforme Figura 4.1-a), com o objetivo de estratificar o leito. O filtro, após a estratificação, era lavado no sentido descendente utilizando o dispositivo de sustentação apresentado na Figura 4.1- b). A lavagem, com água de torneira, era realizada até que os valores de turbidez das águas afluente e efluente fossem equivalentes.

Antes do início da etapa de filtração no tratamento, as colunas de areia eram lavadas de forma descendente com água deionizada. Este procedimento prevenia a contaminação por cloro. O tempo de início da coleta das amostras de água filtrada foi de 20min após o início da filtração, para garantir a substituição completa do volume de água existente nos FLAs no início do ensaio. O desempenho do PAC foi avaliado em função da turbidez medida em uma amostra composta de água filtrada, que foi obtida a partir dos ensaios de decantação utilizando os "pontos ótimos" selecionados no diagrama de coagulação. 

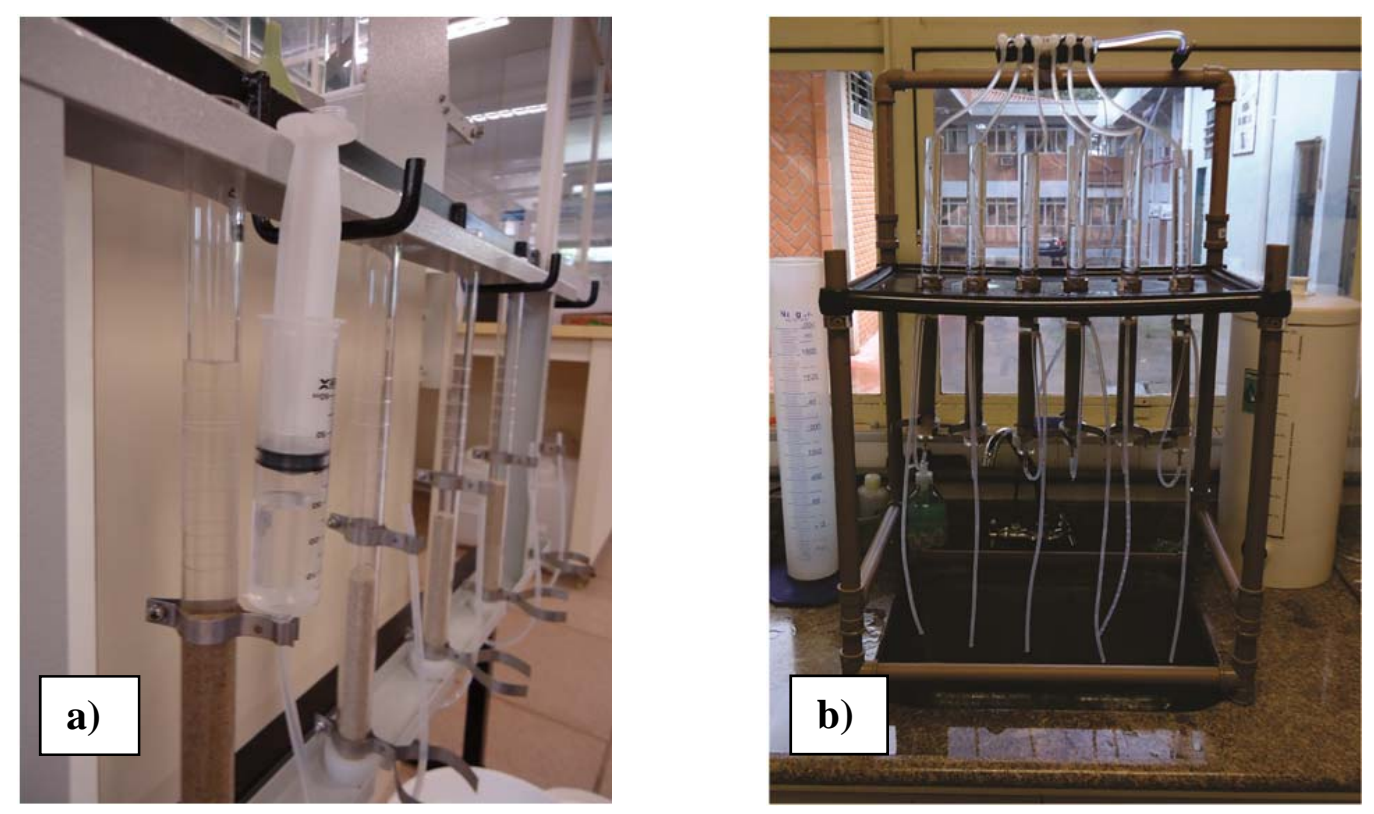

Figura 4.1- a) Lavagem ascendente da areia com auxílio de uma seringa para promover a estratificação do meio filtrante. b) Dispositivo de sustentação para a lavagem descendente do meio filtrante na coluna de filtração.

\subsection{CONTROLE DA QUALIDADE ANALÍTICA DO MÉTODO DE AVALIAÇÃo DE PROTOZOÁRIOS EM ÁGUAS}

$\mathrm{Na}$ avaliação de protozoários foi necessária uma etapa que atestasse a capacidade do analista (aluno) e do laboratório em função da porcentagem de recuperação do método de detecção escolhido. As etapas do controle de qualidade foram:

Precisão inicial e recuperação na água de estudo: foi contaminada artificialmente uma alíquota da água de estudo com uma quantidade conhecida de (oo)cistos (EasySeed ${ }^{\circledR}$ ou ColorSeed ${ }^{\circledR}$ ). Essa etapa visou avaliar o efeito da matriz (água de estudo) sobre a recuperação dos mesmos. Destaca-se que a água de estudo não apresenta (oo)cistos, assim, o uso de EasySeed $^{\circledR}$ ou ColorSeed ${ }^{\circledR}$ foi previsto com o mesmo intuito. A amostra inoculada foi processada de acordo com o protocolo adotado (item 4.3.1). A partir dos resultados gerados, foram calculadas: i) a média da porcentagem de recuperação (média de (oo)cistos recuperados em relação ao número inoculado inicialmente); e ii) o coeficiente de variação -CV (desvio padrão relativo à média de porcentagem de recuperação). As comparações com os padrões estabelecidos pelo Método 1623.1 (USEPA, 2012) foram efetuadas. O desempenho pode ser considerado aceitável se a média e o CV obtidos estivessem dentro dos critérios estabelecidos pelo Método 1623.1. Foi processada, também, amostra de água reagente livre de 
contaminação inicial (controle-negativo) cujo resultado atestou as boas condições vigentes no laboratório, pela ausência de contaminação quando processadas várias amostras.

Diagnóstico e localização de erros: quando os resultados obtidos estavam fora dos limites estabelecidos e a causa não era determinada, foram realizados alguns procedimentos analíticos: i) checagem do sistema de microscopia e do anticorpo analisado, verificando iluminação do microscópio e examinando alíquotas da suspensão controle-positivo presentes no kit comercial dos anticorpos, observando que mais de $50 \%$ dos (oo)cistos apresentassem fluorescência compatível com os padrões previamente estabelecidos; e ii) verificação das etapas de filtração, concentração e eluição, através da contaminação artificial em água reagente (Milli-Q $\left.{ }^{\circledR}\right)$ e execução dessas etapas seguidas da visualização, observando-se a integridade de (oo)cistos durante a leitura das lâminas.

\subsubsection{Detalhes do Controle de Qualidade Analítica na Água de Estudo}

Com a finalidade de atestar a confiabilidade do método de Franco, Rocha-Eberhardt e Cantusio Neto (2001) proposto para a identificação de protozoários nesta pesquisa, uma etapa de controle de qualidade foi necessária. Esta etapa era feita inoculando-se um número conhecido de (oo)cistos em 1 litro da água de estudo. Para tanto, usou-se a suspensão comercial EasySeed ${ }^{\circledR}$, que continha 100 cistos de Giardia spp. e 100 oocistos de Cryptosporidium spp. Também utilizou-se ColorSeed ${ }^{\circledR}$, o qual possuía o mesmo número de organismos do EasySeed ${ }^{\circledR}$. Porém, nesse caso, os (oo)cistos eram marcados com corante vital vermelho fluorescente, distinguindo-se de possíveis (oo)cistos de ocorrência natural na amostra, na mudança para o filtro WG $(\lambda=510$ a $550 \mathrm{~nm})$, na etapa de microscopia. Ressaltase que a água de estudo não apresentava (oo)cistos, assim, o uso de EasySeed $^{\circledR}$ ou ColorSeed $\AA$ foi previsto com o mesmo objetivo - controle do método analítico.

A inoculação era realizada seguindo-se as instruções contidas nos produtos comerciais em questão (ColorSeed ${ }^{\circledR}$ e EasySeed $\left.{ }^{\circledR}\right)$, como descrito a seguir.

Inicialmente, adicionava-se $2 \mathrm{~mL}$ de solução Tween 20 a $0,05 \%$ ao tubo contendo a solução de inóculo. No aparelho de vórtex (Agitador de tubos MA 162- MARCONI®), agitava-se a mistura por $20 \mathrm{~s}$ e dispunha-se a solução em um frasco Erlenmeyer de $2 \mathrm{~L}$ (previamente enxaguado com solução Tween 80 0,1\%) que continha 1 litro de água de estudo (água do poço com turbidez aumentada por caulinita). A mistura foi mantida sob constante agitação magnética (Agitador IKA ${ }^{\circledR}$ C-MAG HS 7). Depois, era realizado o enxágue do tubo com a adição de $3 \mathrm{~mL}$ de água purificada (Milli-Q) e nova agitação no vórtex por 20s. O 
resultado do enxágue era adicionado à água de estudo contida no Erlemeyer de 2L. Após 1 min, repetia-se o enxágue, mais uma vez, com $3 \mathrm{~mL}$ de água purificada.

Com a água de estudo inoculada, as etapas descritas no item 4.4 eram realizadas: concentração, purificação, preparo de lâmina e, finalmente, leitura e contagem dos organismos identificados. O número de (oo)cistos encontrados era comparado com o número de (oo)cistos inoculados, conforme Equação 1. A porcentagem de recuperação era calculada visando estimar a recuperação do método testado.

$$
\% \text { Recuperação }=\frac{N^{\circ}(\text { oo }) \text { cistos recuperados } / L}{N^{0}(\text { oo }) \text { cistos inoculados } / L} \times 100
$$

\section{Equação 1}

\subsection{ENSAIOS DE TRATABILIDADE DA ÁGUA COM INÓCULO DE PROTOZOÁRIOS}

Os ensaios de tratabilidade da água, com inóculo de (oo)cistos de protozoários, foram realizados utilizando os pontos ótimos, em ensaios de jarteste, selecionados nos diagramas de coagulação gerados no item 4.2, em conjunto com FLAs.

\subsubsection{Avaliação dos ProtozoÁrios em amostra de ÁguA}

A água de estudo foi preparada com oocistos de C. parvum e cistos de Giardia spp. em concentrações comumente reportadas em fontes de abastecimento $\left(10^{2}\right.$ a $10^{3}$ (oo)cistos. $\left.\mathrm{L}^{-1}\right)$. Os cistos de Giardia spp. foram obtidos no Laboratório de Protozoologia da Universidade Estadual de Campinas (UNICAMP), onde foram realizados os ensaios de purificação; os oocistos de Cryptosporidium parvum foram adquiridos da Waterborne (EUA).

A metodologia proposta por Franco, Rocha-Eberhardt e Cantusio Neto (2001), baseada na filtração de amostras em membranas de ésteres mistos de celulose, foi utilizada na pesquisa. Autores como Branco (2006), Cantusio Neto (2004), Cantusio Neto et al. (2010), Medeiros (2013) e Santos (2007) têm empregado a técnica, no Brasil.

\subsubsection{CONCENTRAÇÃo DE AMOSTRAS POR FILTRAÇÃo DE MEMBRANA SEGUIDA DE CENTRIFUGAÇÃO}

O procedimento de concentração de amostras por filtração em membranas, seguido ou não por separação imunomagnética, foi realizado sempre no intervalo de um dia de trabalho, conforme recomendações do Método 1623.1. Um esquema geral deste procedimento se apresenta na Figura 4.2. 


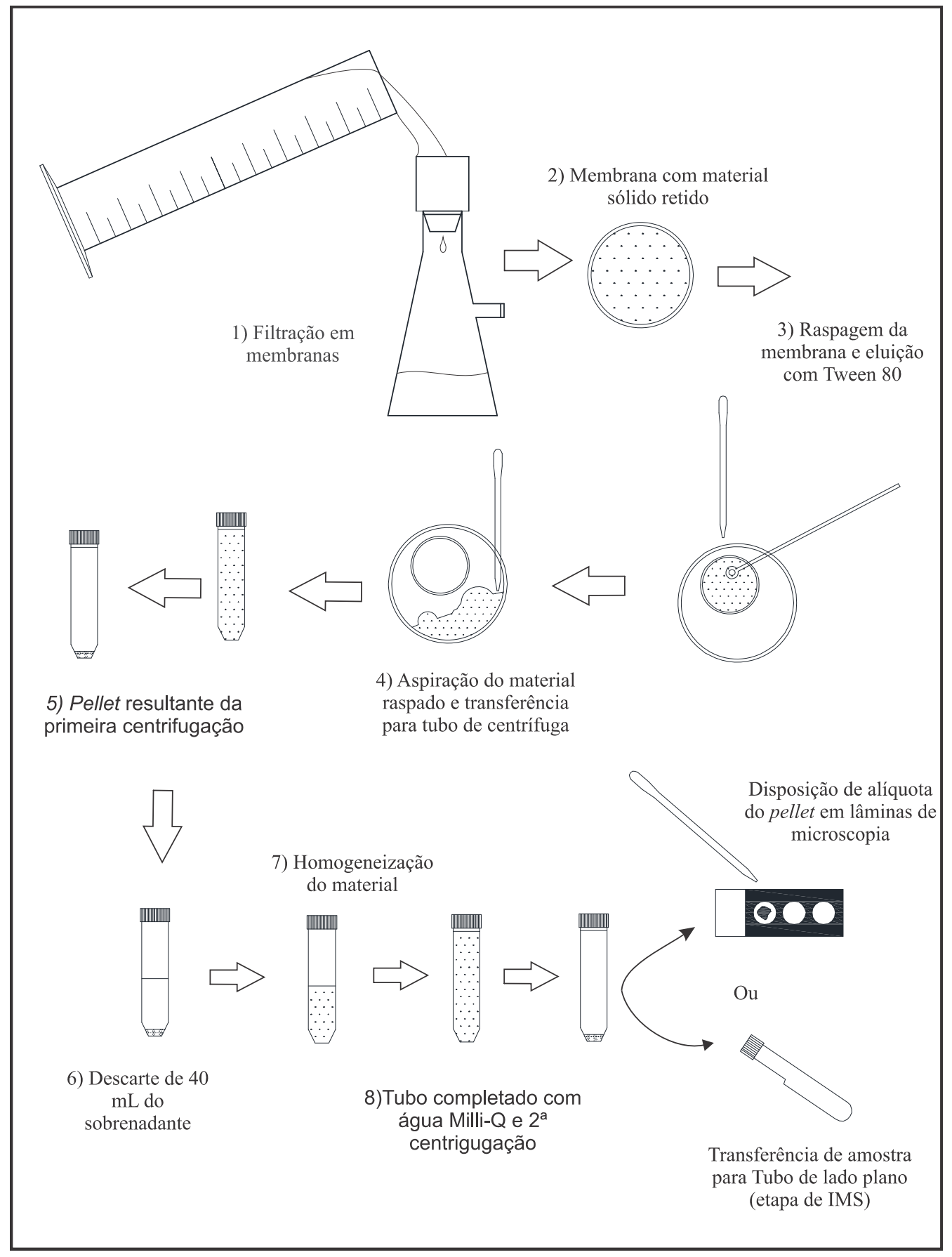

Figura 4.2- Esquema simplificado do procedimento de concentração de (oo)cistos de protozoários aplicado a amostras de água

Uma bomba a vácuo (bomba Millipore ${ }^{\circledR}$ vácuo pressão WP61 115 60) foi utilizada para filtração das amostras em membranas de ésteres mistos de celulose (diâmetro de $47 \mathrm{~mm}$ e porosidade nominal de $3 \mu \mathrm{m}$, Millipore $\left.{ }^{\circledR}\right)$, conforme Figura 4.3. 

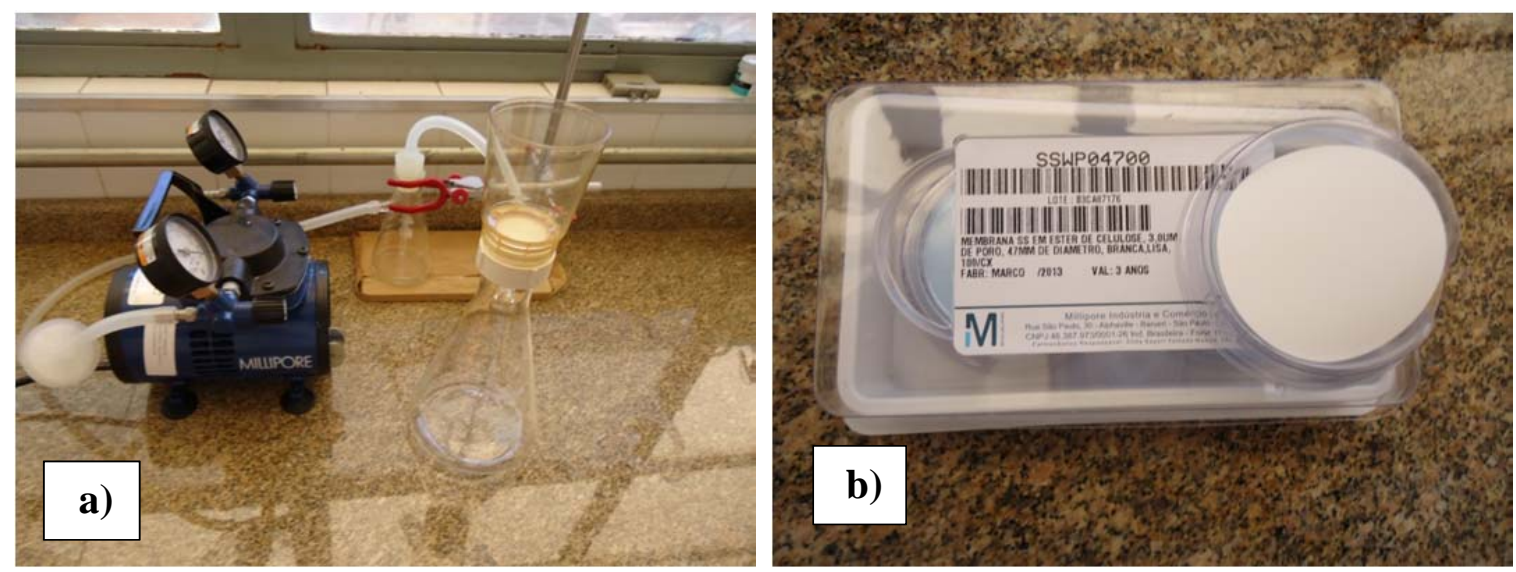

Figura 4.3- Itens utilizados na etapa de filtração em membranas para o procedimento de concentração de protozoários; a) bomba vácuo pressão e conjunto porta-filtro; b) Membrana Millipore ${ }^{\circledR}$ com diâmetro de $47 \mathrm{~mm}$ e porosidade nominal de $3 \mu \mathrm{m}$

A filtração foi mantida com vazão de 1 a 4 L. $\min ^{-1}$ à pressão de $525 \mathrm{mmHg}$. Destaca-se que experiências práticas do Laboratório de Protozoologia da UNICAMP indicam que a pressão não deva ultrapassar $600 \mathrm{mmHg}$ para manter a recuperação dos (oo)cistos dentro dos padrões.

Todo material que entrasse em contato com a amostra contendo protozoários era enxaguado com solução eluente Tween ${ }^{\circledR} 80$ - 0,1\%. A filtração das amostras era feita até o começo do gotejamento visando, sempre, não ultrapassar a pressão de $600 \mathrm{mmHg}$. Nesse momento, a troca da membrana era realizada - caso houvesse ainda volume de amostra a ser filtrado.

Após a filtração a vácuo, as membranas eram cuidadosamente retiradas com uma pinça metálica e transferidas a uma placa de Petri, sobre a qual era realizada a raspagem e lavagem do material retido. A placa era mantida com inclinação. A raspagem era realizada com uma alça plástica macia, presente no kit Merifluor ${ }^{\circledR}$, por movimentos paralelos em um mesmo sentido, seguida da lavagem com solução de eluição Tween ${ }^{\circledR} 80$ 0,1\%.

A lavagem era realizada por meio de uma pipeta Pasteur de plástico de $3 \mathrm{~mL}$. Em cima da membrana era colocado $1,0 \mathrm{~mL}$ da solução de eluição e realizava-se homogeneização do material líquido sobre a placa, resultante da lavagem dos sólidos raspados, com sucessivas sucções e dispensas. Após essa homogeneização, o líquido resultante era transferido para um tubo de centrífuga de $50 \mathrm{~mL}$.

Após o recolhimento do material líquido supracitado, a membrana era rotacionada $90^{\circ}$ para que fosse realizada uma nova raspagem, com estrias perpendiculares às da primeira 
raspagem, com sucessiva lavagem, como descrito anteriormente. O procedimento era repetido uma segunda vez, de forma que todo o processo (3 raspagens seguidas de lavagens) durasse 20 minutos, em acordo com o que foi descrito por Branco (2006). O líquido resultante de cada eluição era reunido no tubo de centrífuga de $50 \mathrm{~mL}$.

Os tubos de centrífuga que recebiam o material proveniente da raspagem e lavagem das membranas eram completados com a mesma solução de eluição até sua marcação de 50 $\mathrm{mL}$ e levados à bandeja do aparelho de centrífuga (Eppendorf ${ }^{\circledR}$ Centrifuge 5810$)$. O peso das 4 bandejas do aparelho deveria ser igual, preservando o pleno funcionamento da centrífuga. Assim, os tubos da centrífuga foram cuidadosamente pesados em balança analítica. A centrifugação era feita a uma rotação de $1500 \times \mathrm{g}$ (2852 rpm) por 15 minutos, conforme USEPA (2012).

Após a primeira centrifugação, observava-se a formação de pellet na base de cada tubo de centrífuga (Figura 4.4), o sobrenadante era aspirado, deixando-se $10 \mathrm{~mL}$ de sedimento nos tubos. Em seguida, o sedimento era ressuspenso até que a solução se tornasse homogênea. Para tanto, levava-se os tubos ao aparelho de vórtex (Figura 4.5). Os tubos contendo $10 \mathrm{~mL}$ de suspensão eram então completados com água purificada (Milli-Q), sendo submetidos a uma nova centrifugação, à mesma rotação $(1500 \times \mathrm{g})$ e tempo (15 minutos).
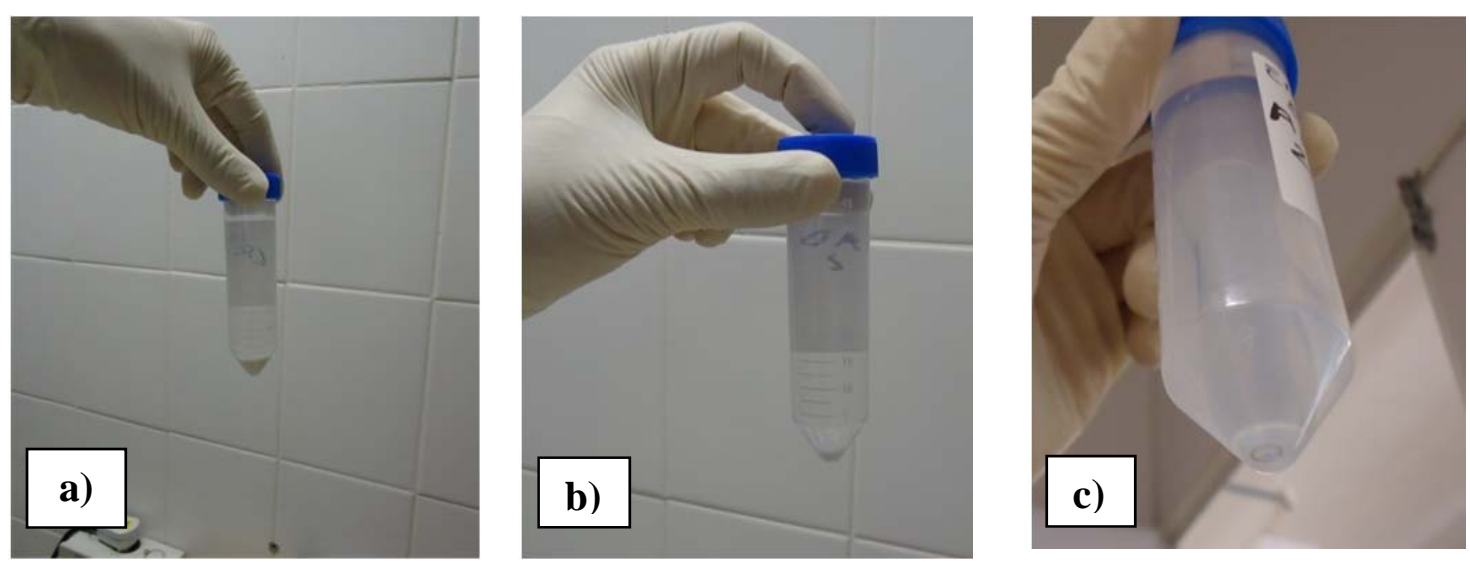

Figura 4.4 - Pellet resultante da centrifugação do líquido da raspagem de membranas, no procedimento de concentração de protozoários, de diferentes amostras. a) lodo; b) água decantada; c) água filtrada.

Caso a amostra fosse encaminhada diretamente à preparação da lâmina de microscopia, no método de imunofluorescência, o sobrenadante da segunda centrifugação era então aspirado e descartado. Deixava-se um sedimento final de 1,0 mL. O sedimento era 
criteriosamente homogeneizado (utilizava-se pipeta pasteur plástica com sucessivas dispensas e sucções nesta etapa, a agitação em vórtex era insuficiente pois o sedimento resultante da centrifugação da água de estudo era muito denso) antes da retirada de alíquotas para a disposição em poços de lâminas de microscopia (Figura 4.6).

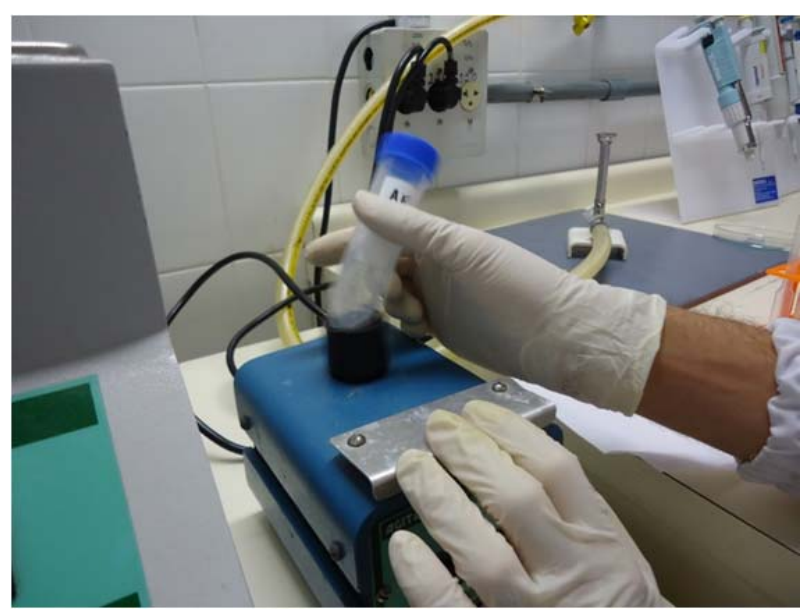

Figura 4.5- Ressuspensão do sedimento da centrifugação no tubo de centrífuga, no procedimento de concentração de protozoários, por aparelho Vórtex.

Caso a amostra fosse encaminhada diretamente à preparação da lâmina de microscopia, no método de imunofluorescência, o sobrenadante da segunda centrifugação era então aspirado e descartado. Deixava-se um sedimento final de 1,0 mL. O sedimento era criteriosamente homogeneizado (utilizava-se pipeta pasteur plástica com sucessivas dispensas e sucções nesta etapa, a agitação em vórtex era insuficiente pois o sedimento resultante da centrifugação da água de estudo era muito denso) antes da retirada de alíquotas para a disposição em poços de lâminas de microscopia (Figura 4.6).
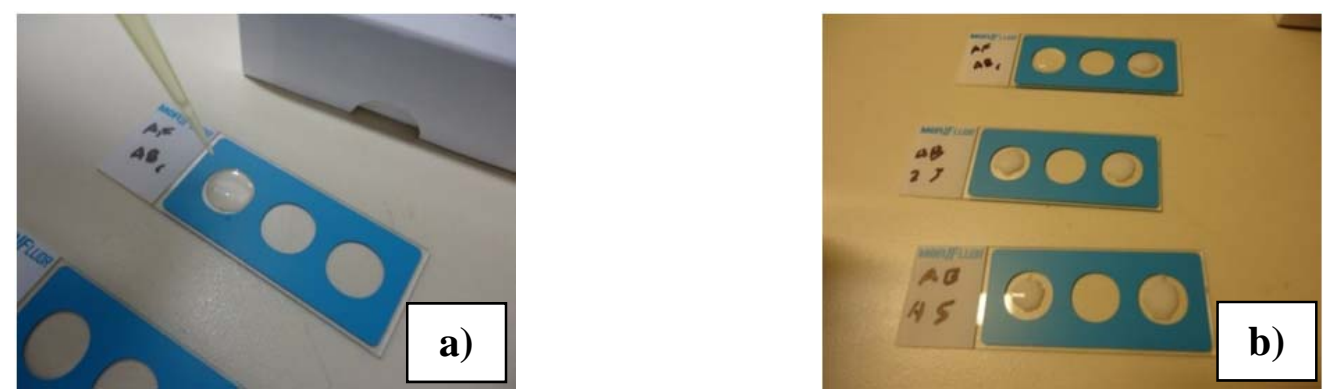

Figura 4.6- Disposição de alíquotas do sedimento final da segunda centrifugação em poços de lâminas do kit Merifluor ${ }^{\circledR}$ a) disposição de alíquota do sedimento de água filtrada em um poço de lâmina do kit Merifluor ${ }^{\circledR}$; b) cinco alíquotas de sedimento final de água bruta e uma alíquota de água filtrada em poços de lâminas do kit Merifluor ${ }^{\circledR}$ 
Caso a amostra fosse submetida a separação imunomagnética, deixava-se um sedimento de no mínimo 5,0 mL, dependendo do volume estimado do pellet, conforme seção 4.4.1.3.

Quanto ao uso ou não da etapa de purificação por IMS, é importante que se tenha conhecimento do número mínimo detectável de organismos de cada metodologia. Este número é estabelecido pela Equação 2.

$N M=\frac{S}{A \times V}$

Equação 2

Em que:

NM: Número mínimo detectável por litro ( (oo)cistos. $\left.\mathrm{L}^{-1}\right)$

S: Volume do sedimento final $(\mu \mathrm{L})$.

V: Volume total da amostra analisada (L).

A: Volume da alíquota do sedimento transferido ao poço da lâmina $(\mu \mathrm{L})$

Obs: Quando a separação imunomagnética foi empregada, os valores de "A" e "S" eram os mesmos para este trabalho (o volume do sedimento final era transferido totalmente ao poço da lâmina).

\subsubsection{Divisão da Amostra para A Utilização SimultâneA COM E SEM A SEPARAÇÃO IMUNOMAGNÉTICA}

Quando não se realizava a separação imunomagnética (IMS), o volume do pellet encaminhado para a microscopia representava 5\% (para o caso da água bruta) e 7,5\% (para o caso da água filtrada) do total da amostra concentrada. O restante do material era potencialmente utilizável e, por isso, optou-se por submetê-lo à separação imunomagnética. Dessa forma, realizava-se simultaneamente à concentração de amostra com e sem a purificação por IMS. O procedimento igualmente visava a comparação entre os métodos partindo da mesma amostra.

Após a segunda centrifugação, descartava-se o sobrenadante, deixando-se $5 \mathrm{~mL}$ no tubo de centrífuga. Retirava-se cuidadosamente $4 \mathrm{~mL}$ do sobrenadante e dispunha-se em um frasco previamente enxaguado com solução de Tween ${ }^{\circledR} 80$ 0,1\%.

O sedimento resultante era homogeneizado de forma a se retirar alíquotas para aplicação no poço de lâmina de imunofluorescência, sem o procedimento de IMS. Ao volume restante 
do pellet eram retornados $4 \mathrm{~mL}$ da água anteriormente retirada e esta solução era encaminhada à etapa de separação imunomagnética.

\subsubsection{PURIFICAÇÃO dOS SEDIMENTOS MEDIANTE SEPARAÇÃo IMUNOMAGNÉTICA}

A etapa de purificação por IMS era realizada conforme o esquema simplificado da Figura 4.7. Inicialmente, estimava-se o volume do pellet presente na amostra. Para tanto, um tubo de centrífuga idêntico ao que continha a amostra era preenchido com $500 \mu \mathrm{L}$ de uma solução com coloração forte para fim de comparação. Diante das duas possibilidades, volume de pellet menor ou maior que $500 \mu \mathrm{L}$, procedia-se da seguinte forma:

No caso de volume do pellet menor que $500 \mu \mathrm{L}$ : era utilizada uma pipeta Pasteur plástica para aspirar o sobrenadante até a marcação de $5 \mathrm{~mL}$ do tubo de centrífuga. $\mathrm{O}$ conteúdo do tubo era homogeneizado

No caso de volume de pellet maior que $500 \mu \mathrm{L}$ : o volume de sobrenadante a ser deixado dependeria do volume estimado do pellet, obedecendo à seguinte relação: volume mínimo de sobrenadante $(\mathrm{mL})=($ volume do pellet $(\mathrm{mL}) / 0,5 \mathrm{~mL}) \times 5 \mathrm{~mL}$. O procedimento era então feito de forma análoga ao primeiro caso.

Destaca-se que por se tratar de uma pesquisa com água de estudo, as amostras não apresentavam variação significativa no volume do pellet formado, sendo este inferior a 500 $\mu \mathrm{L}$ para as águas "bruta", "decantada" e "filtrada". A única amostra que apresentava pellet com volume superior a $500 \mu \mathrm{L}$ foi a de lodo.

A separação imunomagnética (IMS) era realizada conforme instruções do fabricante (Kit Dynabeads ${ }^{\circledR}$ Life tecnologies ${ }^{\mathrm{TM}}$ ). Em um tubo L10 (tubo de lado plano - TLP) (Figura 4.8- a) adicionava-se $1 \mathrm{~mL}$ de solução tampão SL-A $10 \mathrm{X}$ e $1 \mathrm{~mL}$ de solução tampão SL-B, ambos fornecidos pelo kit. Incluia-se, ainda, o conteúdo de amostra processado até o fim da etapa de concentração. No caso de volume transferido inferior a $10 \mathrm{~mL}$, realizava-se 2 enxágues com água purificada (água Milli-Q) no tubo que continha a amostra. Tal procedimento teve como objetivo garantir que todo o volume de amostra transferido ao tubo de lado plano junto com as soluções tampão não ultrapassasse $10 \mathrm{~mL}$.

Em seguida, era realizada a adição dos anticorpos, conjugados às microesferas magnéticas, específicos para os antígenos das paredes dos cistos de Giardia spp. e oocistos de Cryptosporidium spp. A solução contendo estes complexos são chamadas Dynabeads ${ }^{\circledR}$ antiGiardia e Dynabeads ${ }^{\circledR}$ anti-Cryptosporidium, para a separação de cistos de Giardia spp. e oocistos de Cryptosporidium spp., respectivamente. 


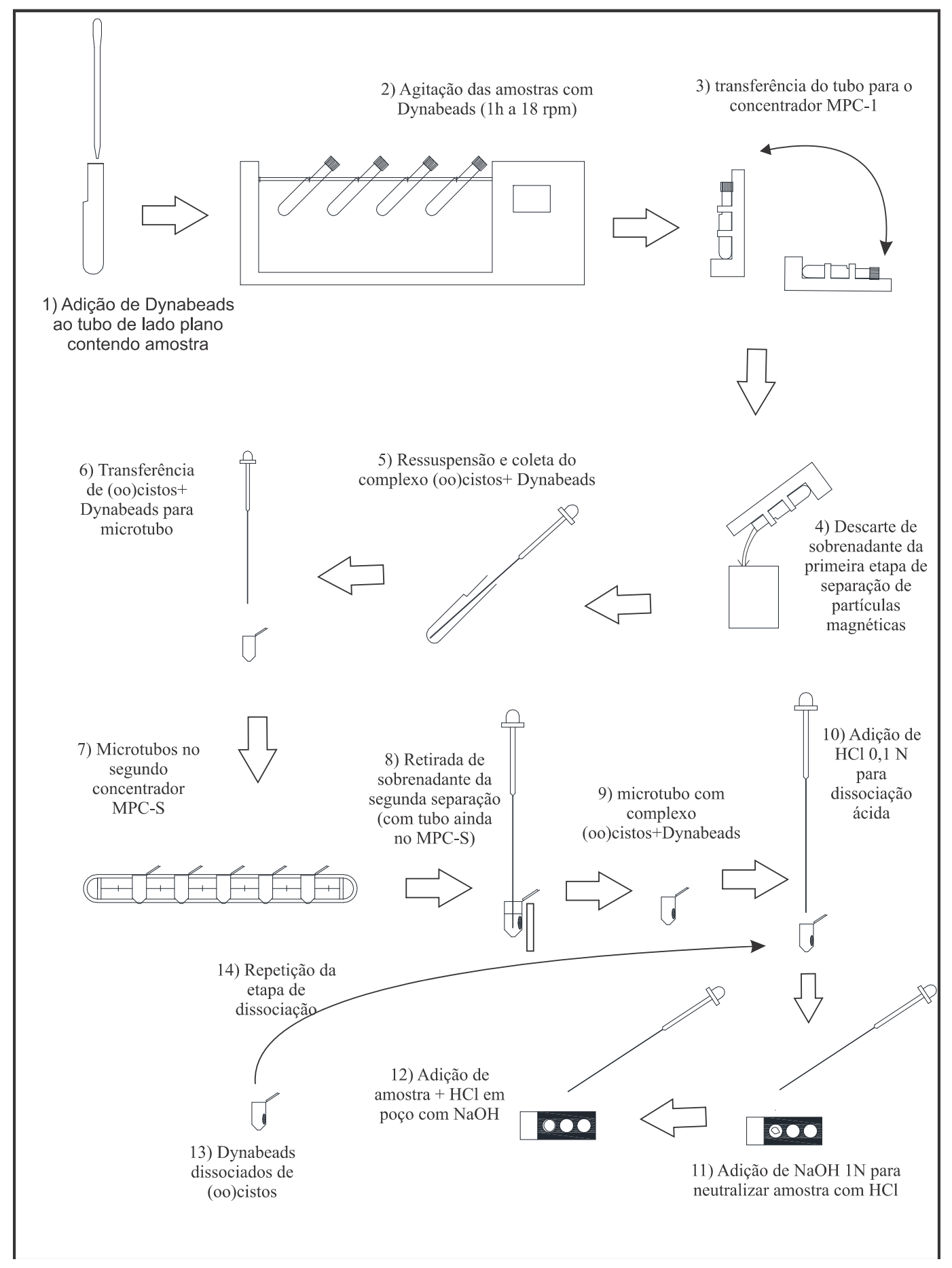

Figura 4.7- Esquema simplificado das etapas do procedimento de IMS

Cada uma das soluções era agitada em aparelho vórtex, com o objetivo de homogeneizar por completo o conteúdo dos recipientes, tomando o devido cuidado para se evitar a adesão de material nas tampas dos frascos. Imediatamente após cada agitação, transferia-se $100 \mu \mathrm{L}$ de cada solução aos TLP previamente preenchidos com amostras e soluções tampão presentes no kit (Figura 4.8-b). 


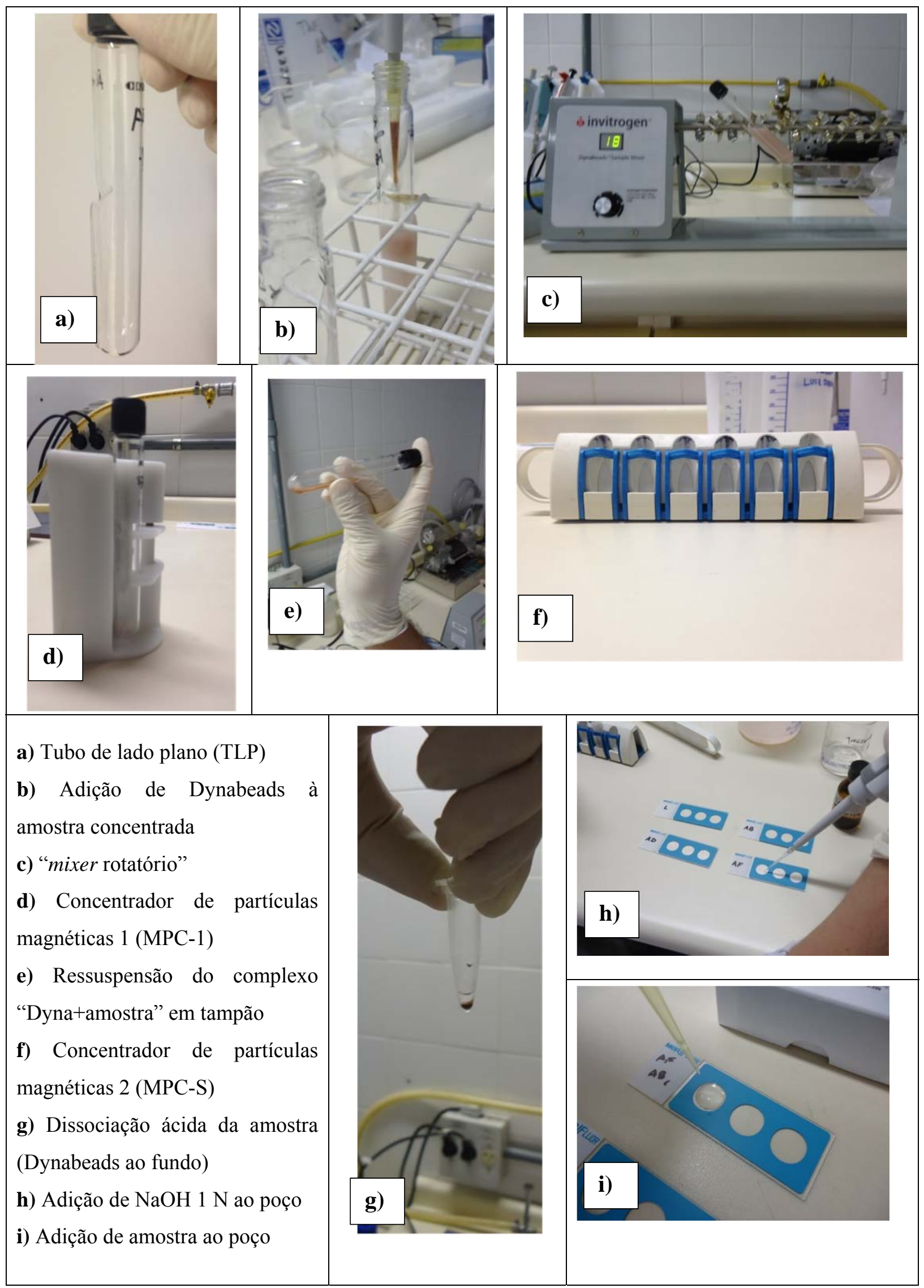

Figura 4.8- Acessórios, equipamentos e ações da etapa de purificação por IMS 
Posteriormente, era realizada a mistura de todo conteúdo presente nos TLP. Este ato era feito fixando-se os tubos em um misturador rotatório específico para este procedimento (Invintrogen Dynabeads ${ }^{\circledR}$ Sample Mixer), o qual era mantido sob agitação de $18 \mathrm{rpm}$ por 1 hora, à temperatura ambiente (Figura 4.8-c).

Após o período de agitação, o tubo era levado ao concentrador de partículas magnéticas (Invitrogen Dynal MPC-1), com o lado plano voltado para o ímã do acessório (Figura 4.8-d).

Movimentos manuais eram realizados em um ângulo de $90^{\circ}$, inclinando a extremidade da tampa do tubo para cima e para baixo, sendo que o lado do ímã permanecia em contato com o líquido tanto na posição horizontal como na vertical.

Estes movimentos eram feitos continuamente por 2 minutos, com uma inclinação por segundo. O MPC-1, junto ao tubo L10, era retornado à posição vertical, com a tampa voltada para cima, a qual era removida para o descarte do sobrenadante. $\mathrm{O}$ descarte era feito com o tubo ainda preso ao MPC-1 e com as partículas magnéticas atraídas pelo ímã no lado plano. O lado do MPC-1 que continha o ímã permanecia voltado para cima no momento do descarte.

Após o descarte do sobrenadante do TLP, este era removido do MPC-1 e a amostra era ressuspensa em $0,5 \mathrm{~mL}$ do tampão SL-A X (o tampão presente no kit, dessa vez, diluído em 10 vezes). A amostra era suavemente misturada com o tampão diluído, com movimentos na horizontal (Figura 4.8-e). Ao mesmo tempo, as laterais eram bem enxaguadas, evitando a perda de material seco. Quando a solução adquiria aspecto homogêneo, era transferida para um microtubo de centrífuga de 1,5 mL, por meio de uma pipeta Pasteur de vidro de $230 \mathrm{~mm}$. Em seguida, realizavam-se mais dois enxágues com o tampão SL-A X, de forma a completar o volume do microtubo de centrífuga.

No caso de processamento simultâneo de mais de uma amostra, quando a primeira era encaminhada ao concentrador de partículas magnéticas, as outras deviam continuar sob agitação no misturador rotatório. Isto era feito de forma que nenhuma amostra permanecesse em repouso antes da etapa de concentração de partículas magnéticas.

O microtubo de centrífuga contendo a amostra era levado a um segundo concentrador de partículas magnéticas (Invitrogen Dynal MPC-S) (Figura 4.8-f), este concentrador possui uma fita magnética removível, a qual devia permanecer corretamente encaixada no momento do posicionamento do microtubo. O MPC-S era suavemente agitado em movimento de $180^{\circ}$ durante 1 minuto e, aproximadamente, 1 balanço por segundo. Ao fim desta etapa, as partículas produziam uma nítida mancha marrom na parte de trás do tubo, a que ficava em contado com o ímã. O sobrenadante era imediatamente aspirado do tubo e da tampa, com o 
tubo ainda mantido no MPC-S. A aspiração era feita com uma pipeta Pasteur de vidro de 230 $\mathrm{mm}$.

O microtubo contendo complexos de anticorpos de captura + microesferas + cistos e oocistos era encaminhado para que se realizasse a dissociação dos (oo)cistos das micro esferas magnéticas, o que podia ser feito por duas formas: dissociação ácida ou térmica. Nesta pesquisa, realizou-se a dissociação ácida porque a térmica não gerou resultados compatíveis com o Método 1623.1.

\subsection{Dissociação ácida dos (oo)cistos a partir dos complexos microesferas + anticorpos de captura $+($ oo $)$ cistos}

$\mathrm{Na}$ etapa de dissociação ácida, a fita magnética era removida do MPC-S e, posteriormente, o microtubo de centrífuga contendo amostra era enxaguado com $50 \mu \mathrm{L}$ de ácido clorídrico $0,1 \mathrm{~N}$. O tubo era então levado ao vórtex para que o material fosse homogeneizado, etapa que era realizada com muito cuidado, evitando-se que partículas se aderissem às paredes ou tampa do tubo. Certificava-se que toda a amostra estivesse na base do tubo.

Após a homogeneização, o tubo era colocado de volta no MPC-S, sem a fita magnética, para permanecer na posição vertical e em repouso, por um período de 10 minutos. Passado este tempo, a amostra, que apresentava nítida distinção entre as fases (Figura 4.8-g), era novamente homogeneizada no aparelho de vórtex e recolocada no MPC-S, com a fita magnética. Novamente, certificava-se de que o material estivesse na base do tubo. Este era, então, deixado em repouso por um período mínimo de 10 segundos.

Observava-se a formação de uma mancha marrom circular na parede interna do tubo, na face do mesmo que havia permanecido em contato com o ímã. O material sobrenadante $(50 \mu \mathrm{L})$ era coletado por uma micropipeta automática, com sua ponteira previamente enxaguada com solução de eluição e levado ao poço da lâmina do kit Merifluor ${ }^{\circledR}$ (Figura 4.8i).

Ao poço da lâmina de microscopia era adicionado $5 \mu \mathrm{L}$ de hidróxido de sódio padrão $1 \mathrm{~N}$, antes da adição do material sobrenadante da etapa anterior, para neutralizar os $50 \mu \mathrm{L}$ de ácido clorídrico 0,1 N (Figura 4.8-h)).

O procedimento de dissociação ácida era repetido mais uma vez para aumentar a recuperação. Assim, adicionava-se novamente $5 \mu \mathrm{L}$ de hidróxido de sódio padrão $1 \mathrm{~N}$ ao outro poço da lâmina que receberia o volume proveniente da segunda dissociação. 
Realizava-se em seguida o procedimento de preparo da lâmina para o exame de microscopia de imunofluorescência.

\subsection{Dissociação térmica dos (oo)cistos a partir dos complexos microesferas + anticorpos de captura $+($ oo $)$ cistos}

O processo de dissociação térmica era realizado de maneira semelhante à ácida. Após descarte do sobrenadante do microtubo de centrífuga, adicionava-se $50 \mu \mathrm{L}$ de água Milli-Q à amostra. O material era homogeneizado em aparelho de vórtex e o tubo levado ao aquecimento em banho-maria (ou aparelho de banho seco) à temperatura de $80^{\circ} \mathrm{C}$, na posição vertical, por 10 minutos. Após esse período, o material era novamente homogeneizado em aparelho de vórtex e levado ao MPC-S, com a fita magnética. Após um período de 10 segundos, recolhia-se a amostra e realizava-se a transferência para um microtubo de centrífuga com o identificação da amostra. Repetia-se o procedimento uma vez, para aumentar a recuperação. Transferia-se a amostra para o mesmo microtubo identificado, do qual se retirava uma alíquota para aplicação em lâmina de microscopia.

\subsubsection{ETAPA DE MICROSCOPIA POR IMUNOFLUORESCÊNCIA}

Decorrida a etapa de concentração dos (oo)cistos, um volume desse concentrado era transferido para a lâmina de microscopia, presente no kit Merifluor ${ }^{\circledR}$. O volume dependia do tipo de amostra e se ela havia sido processada pelo procedimento de purificação por separação imunomagnética.

Para o primeiro caso (água bruta), na situação em que não se realizava a separação imunomagnética, eram transferidas 5 alíquotas de $10 \mu \mathrm{L}$ para a lâmina do kit Merifluor ${ }^{\circledR}$. Este procedimento foi adotado nesta pesquisa em função dos resultados obtidos sobre a qualidade de visualização dos poços. Para análise da água filtrada, sem separação imunomagnética, era processada uma alíquota de $75 \mu \mathrm{L}$ por amostra.

Para análise das amostras de água bruta, água decantada, água filtrada e lodo, com separação imunomagnética, o volume transferido para o poço da lâmina foi de $50 \mu \mathrm{L}$, o que representava $100 \%$ do volume do sedimento final.

A alíquota determinada do sedimento era colocada, completamente homogeneizada, no poço da lâmina do kit Merifluor ${ }^{\circledR}$. Deixava-se a amostra secar à temperatura ambiente, o que poderia demandar um longo período, especialmente para o caso das amostras de água bruta e lodo. 
Padronizou-se deixar o conteúdo disposto na lâmina secar overnight - procedimento fundamental para que o conteúdo da amostra na lâmina estivesse completamente seco (Figura 4.9). O método 1623.1 indica que se pode esperar até 72 horas entre a disposição do material na lâmina e a preparação da mesma com os reagentes de microscopia.

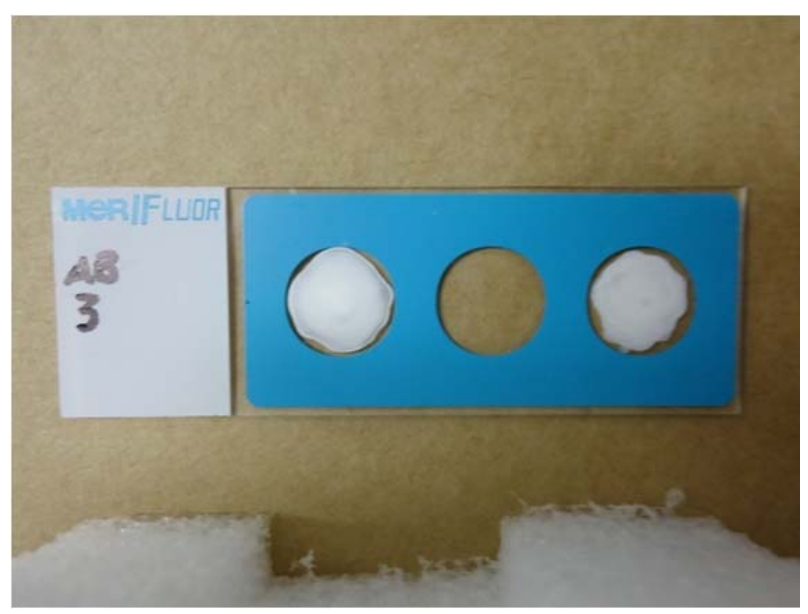

Figura 4.9- Poços com alíquotas de sedimento de água bruta, sem purificação por IMS, completamente secas e aptas para etapa de preparação de lâminas para microscopia

Para fixação da amostra, após seca, pipetava-se $10 \mu \mathrm{L}$ de metanol (Metanol anidro 99,8\% Sigma-Aldrich ${ }^{\circledR}$ ) sobre o centro do poço da lâmina, deixando-se secar por um período de 10 minutos. A lâmina era, então, levada a uma câmara úmida e escura como as da Figura 4.10, e processada com os reagentes do kit Merifluor ${ }^{\circledR}$. Colocava-se 1 gota do reagente de detecção sob o centro da amostra seguida de 1 gota do contra-corante. Logo após, a câmara era mantida ao abrigo da luz, por um período de 30 minutos.

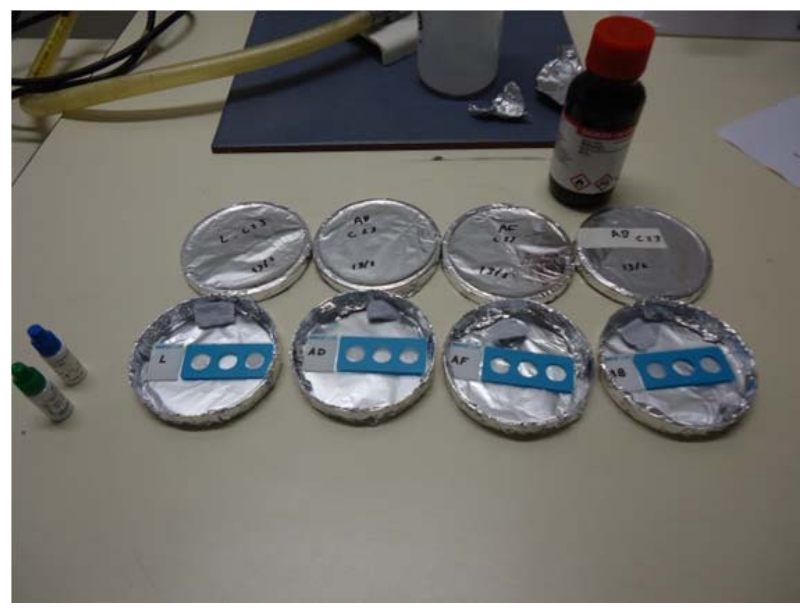

Figura 4.10- Lâminas do kit Merifluor ${ }^{\circledR}$ abrigadas em câmaras úmidas e escuras, antes de receber o tratamento com os reagentes de detecção do kit 
Decorrido o tempo supracitado, a lâmina era removida da câmara e realizava-se a lavagem da mesma com 3 aplicações de $10 \mu \mathrm{L}$ com solução tampão do kit Merifluor ${ }^{\circledR}$ diluída 20 vezes. As lâminas eram inclinadas durante a lavagem, removendo-se o excesso com um papel absorvente (a exceção era a amostra de água bruta, sem o procedimento de IMS que era muito densa, neste caso, removia-se o excesso de tampão de lavagem com uma pipeta pasteur de vidro, sem inclinar a lâmina).

Em seguida, realizava-se a aplicação do corante vital DAPI (4',6-diamidino-2fenilindol) (DAPI - Sigma-Aldrich $\left.{ }^{\circledR}\right)$. Para tanto, preparou-se uma solução-mãe do corante à proporção de $2 \mathrm{mg}$ de DAPI por $\mathrm{mL}$ de metanol. Aplicava-se $50 \mu \mathrm{L}$ de DAPI (concentração 1:2500 em PBS) no centro do poço da lâmina, levava-se a mesma para a câmara úmida e escura, onde era deixada por 10 minutos. Realizava-se o mesmo procedimento de lavagem com solução tampão descrito anteriormente para a retirada do excesso de DAPI.

Logo, aplicava-se $10 \mu \mathrm{L}$ de água purificada (Milli-Q), após a lavagem com solução tampão, para evitar a formação de cristais na lâmina, após 1 minuto retirava-se o excesso e aplicava-se 1 gota do meio de montagem, presente no kit Merifluor ${ }^{\circledR}$.

Finalmente, dispunha-se cuidadosamente uma lamínula sobre o poço da lâmina contendo amostra, evitando a formação de bolhas. A lâmina era, então, retornada à câmara úmida e escura, conservada em geladeira à temperatura de 2 a $8{ }^{\circ} \mathrm{C}$, e encaminhada para a leitura em microscopia de imunofluorescência.

\subsubsection{IDENTIFICAÇÃO E CONTAGEM DOS (OO)CISTOS NA MICROSCOPIA DE IMUNOFLUORESCÊNCIA}

Depois da preparação da lâmina com os reagentes do kit Merifluor ${ }^{\circledR}$, esta estava apta para a leitura no microscópio (Olympus ${ }^{\circledR}$ BX51).

A leitura das lâminas era realizada sob o aumento de 200X, para identificação de organismos similares aos cistos e oocistos e em até 800X, para a confirmação dos (oo)cistos. Aspectos morfológicos confirmatórios por meio do corante DAPI eram vistos sob o aumento de 400X, bem como a identificação de estruturas internas pela microscopia de luz em DIC.

Segundo critérios de USEPA (2012), na caracterização de organismos alvos desta análise, o exame em fluorescência FITC (isotiocianato de fluoresceína) em reação de imunofluorescência direta (RID) deve identificar, para o caso de oocistos de Cryptosporidium spp., objetos ovoides ou esféricos de 4 a $6 \mu \mathrm{m}$ de diâmetro em cor maçã-verde fluorescente. 
Para o caso dos cistos de Giardia spp., objetos ovoides de 8 a $18 \mu \mathrm{m}$ de comprimento por 5 a $15 \mu \mathrm{m}$ de largura, com coloração também maçã-verde fluorescente.

Simultaneamente à RID, realizava-se o teste confirmatório da morfologia dos núcleos dos esporozoítos (oocistos) ou dos cistos com o corante fluorogênico DAPI. Segundo USEPA (2012), o objeto alvo deve apresentar uma ou mais das seguintes características, válidas para cistos e oocistos: i) coloração azul interna, sem distinção do núcleo e membrana verde (DAPI negativo); ii) intensa coloração interna azul (DAPI positivo); e iii) até 4 núcleos distintos, em coloração azul (DAPI positivo).

Ainda, realizou-se análise de microscopia em DIC (microscopia de contraste interferencial diferencial). Utilizava-se um aumento de 400x nesta análise. Considerou-se os seguintes critérios para a confirmação da presença dos (oo)cistos: i) (oo)cisto vazio; ii) (oo)cisto com estrutura amorfa; iii) oocisto de Cryptosporidium spp. com estrutura interna - 1 a 4 esporozoítos por oocistos e cistos de Giardia spp. com um tipo de estrutura interna núcleo ou axonemas, ou ambos

Após a identificação e enumeração dos (oo)cistos de protozoários, calculava-se a estimativa do número de oocistos por litro de amostra analisada. $\mathrm{O}$ cálculo era feito com a Equação 3, separando-se a contagem de cistos de Giardia spp. e oocistos de Cryptosporidium spp.

$E=\frac{N \times S}{V \times A} \times F C$

Equação 3

Em que:

E: Estimativa do número de (oo)cistos por litro de amostra ( (oo)cistos. $\left.\mathrm{L}^{-1}\right)$.

$\mathrm{N}$ : Número de (oo)cistos visualizados no(s) poço(s) da lâmina de imunofluorescência.

S: Volume do sedimento final $(\mu \mathrm{L})$.

V: Volume total da amostra analisada (L).

A: Volume da alíquota transferido ao poço da lâmina $(\mu \mathrm{L})$.

FC: Fator de correção para os casos das amostras de lodo (volume total/volume concentrado)

Obs: Quando a separação imunomagnética foi empregada, os valores de "A" e "S" eram os mesmos para este trabalho (o volume do sedimento final era transferido totalmente ao poço da lâmina). 
Após a determinação do número de oocistos presentes nas amostras analisadas era possível se estimar o número destes organismos em cada etapa do tratamento proposto. Este cálculo era realizado multiplicando-se o valor calculado na Equação 3 pelo volume final de cada etapa do tratamento proposto (água bruta, água decantada, água filtrada e lodo, ressuspenso em água deionizada). O número de (oo)cistos na etapa do tratamento era, então, calculado pela Equação 4.

$N E=E \times V F$

\section{Equação 4}

Em que:

$\mathrm{NE}=$ Número de (oo)cistos na etapa do tratamento.

$\mathrm{E}=$ Estimativa do número de (oo)cistos por litro de amostra ( (oo)cistos. $\mathrm{L}^{-1}$ ).

$\mathrm{VF}=$ Volume da amostra na fase do tratamento.

O volume da água bruta foi fixado em 12 litros (2,2 litros de cada jarro do jarteste, com posterior retirada de 1,2 L para análise de protozoários como se descreve no ítem 4.4.2.). $\mathrm{O}$ volume da água filtrada era medido e anotado em cada procedimento de filtração por membranas e era sempre superior a 5 litros. A água considerada como água decantada neste experimento era o volume que ficava abaixo do furo do jarro do jarteste após o final da filtração e acima da região do lodo. Esta possuía variação de volume semelhante à da água filtrada e o volume anotado da mesma maneira.

O volume de lodo ressuspenso levado ao procedimento de concentração de protozoários era próximo a 2 litros. No caso dos experimentos com a segunda condição de coagulação (com dosagem elevada e formação de lodo denso), um terço do volume ressuspenso (próximo a 6 litros) era levado ao procedimento de filtração por membranas.

\subsubsection{EXPERIMENTOS EM ESCALA DE BANCADA PARA REMOÇÃo DE (OO)Cistos DE Protozó́rios}

Com base nas condições definidas no item 4.2, realizou-se ensaios em jarteste para avaliar o desempenho do tratamento proposto (coagulação, floculação, decantação, filtração) para a remoção dos (oo)cistos de protozoários na água de estudo. O procedimento detalhado das tarefas envolvidas no ensaio em escala de bancada é descrito no esquema da Figura 4.11. 
Cada condição era testada em triplicata, no mínimo. Além disso, o tratamento era avaliado por duas metodologias de identificação de protozoários: i) sem o procedimento de separação imunomagnética; e ii) com etapa de purificação por separação imonomagnética. 


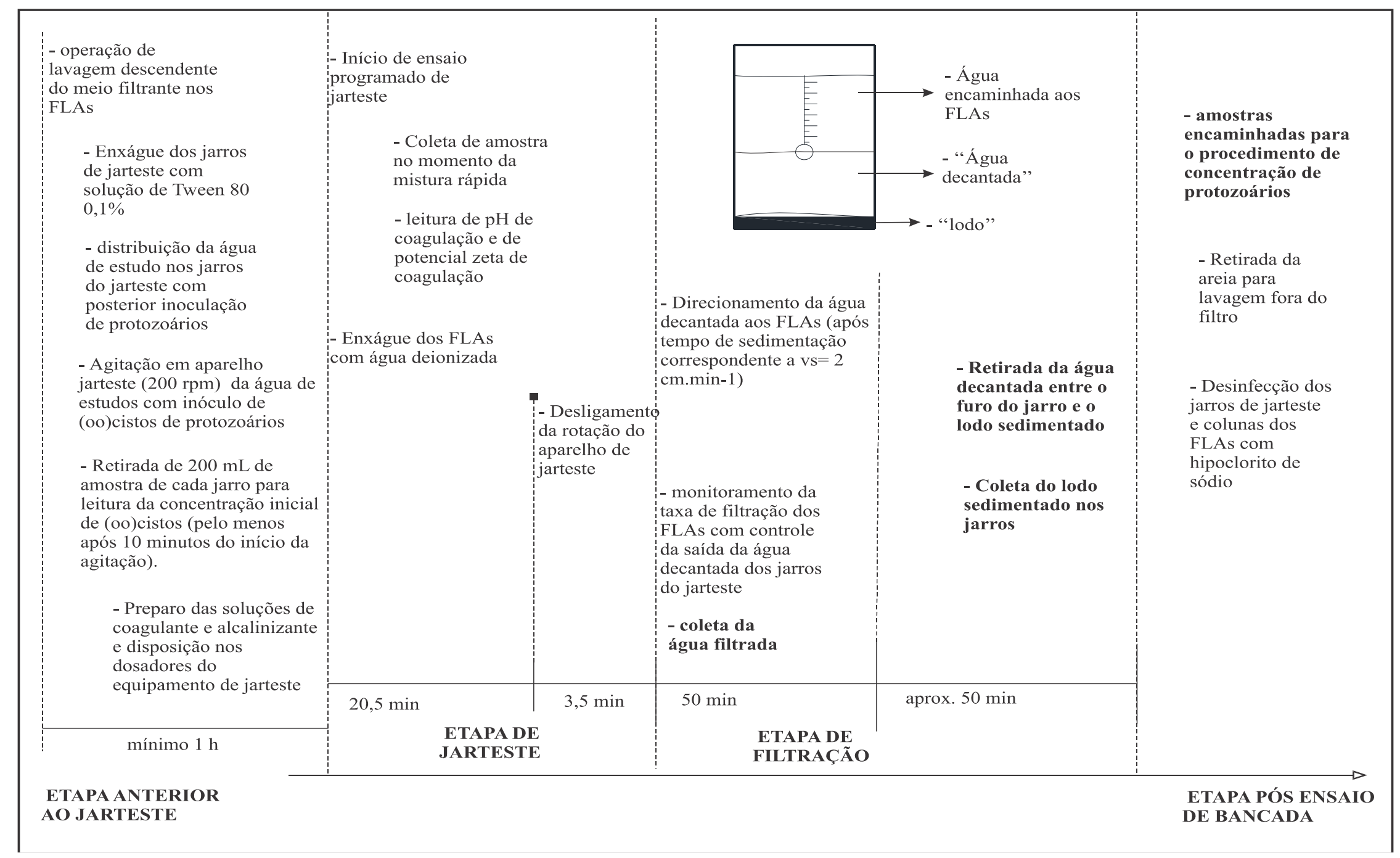

Figura 4.11- Esquema detalhado das tarefas envolvidas na realização dos ensaios de tratabilidade, com inoculação de protozoários, em escala de bancada 
O primeiro passo era a disposição da água de estudo com turbidez elevada nos jarros do equipamento jarteste. Uma marcação de $200 \mathrm{~mL}$ acima do nível de 2 litros foi realizada nos jarros, com o objetivo que será descrito posteriormente. O equipamento era então ligado e mantido sob uma agitação de $200 \mathrm{rpm}$, de modo a manter a amostra homogênea.

Para avaliar o tratamento proposto, era inoculada uma concentração estimada de 500 de cistos de Giardia spp. por litro e de 500 oocistos de C. parvum por litro, distribuídos nos 6 jarros do jarteste, previamente enxaguados com solução Tween 80 a 0,1\%.

A estimativa do número de cistos de Giardia spp. e oocistos de C. parvum era feita da seguinte forma: dispunha-se 3 alíquotas de 5 microlitros da solução concentrada de cada protozoário em poços de lâminas do kit Merifluor ${ }^{\circledR}$, realizava-se o procedimento de preparação das lâminas, com a enumeração dos protozoários. Por meio da média era possível estimar a quantidade de (oo)cistos presente em dado volume da solução concentrada.

A enumeração da suspensão inócula era realizada previamente aos ensaios, para confirmar a inexistência de agregados de cistos ou oocistos (Figura 4.16), considerando-se o tempo de armazenamento da suspensão, anteriormente à realização dos ensaios experimentais. A solução de oocistos de C. parvum disponíveis para este trabalho possuíam tempo de armazenamento superior a 3 meses. Estes oocistos estavam sujeitos à formação de agregados, o que não possibilitaria a distribuição uniforme destes organismos em meio líquido. Para superar este problema, um procedimento que visa romper os agregados foi realizado, seguindo recomendações das práticas do Laboratório de Protozoologia da Unicamp, adaptado de Lindquist et al.(1999).
A. O inóculo era diluído com Tween 20 a 0,01\%;
B. Pipetava-se vigorosamente 20 vezes;
C. Centrifugava-se a $1500 \mathrm{x} g$ por 10 minutos;
D. Retirava-se o sobrenadante e se completava com PBS até a marca de $1 \mathrm{~mL}$; e
E. Fazia-se nova contagem da solução em alíquotas de $5 \mu \mathrm{L}$.

O número de (oo)cistos na água de estudo com inóculo foi quantificado; para tanto, após ser realizada a inoculação, mantinha-se a água sob agitação nos jarros por um período de, no mínimo, $10 \mathrm{~min}$ e recolhia-se $200 \mathrm{~mL}$ de amostra de cada jarro (marca de nível adicional). O procedimento permitiu ter uma amostra composta de 1,2L para posterior quantificação da concentração de entrada dos (oo)cistos. 


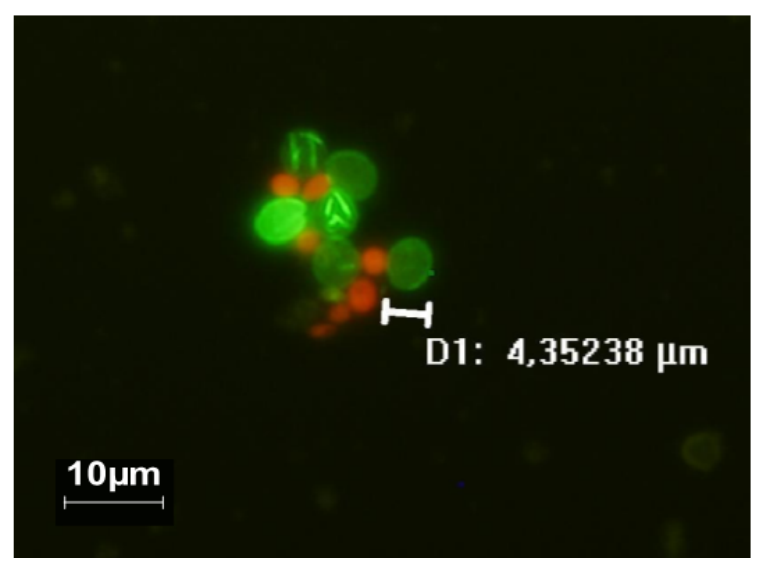

Figura 4.12- Oocistos de C. parvum agregados, presentes nas suspensão comercialmente adquirida, após meses de armazenamento (aum: 400x)

O equipamento de jarteste seguia com a programação feita segundo as condições determinadas no item 4.2. Ao fim da etapa de mistura rápida, recolhia-se uma amostra para a leitura do pH de coagulação e do Potencial Zeta (Figura 4.13-a). A Figura 4.13 -b mostra o início da formação de flocos em jarros do Jarteste.

No ensaio de jarteste, entre a floculação e a decantação, era realizada a lavagem descendente dos FLAs com água deionizada de modo a substituir toda água que estivesse repousada no meio filtrante (Figura 4.13-c).
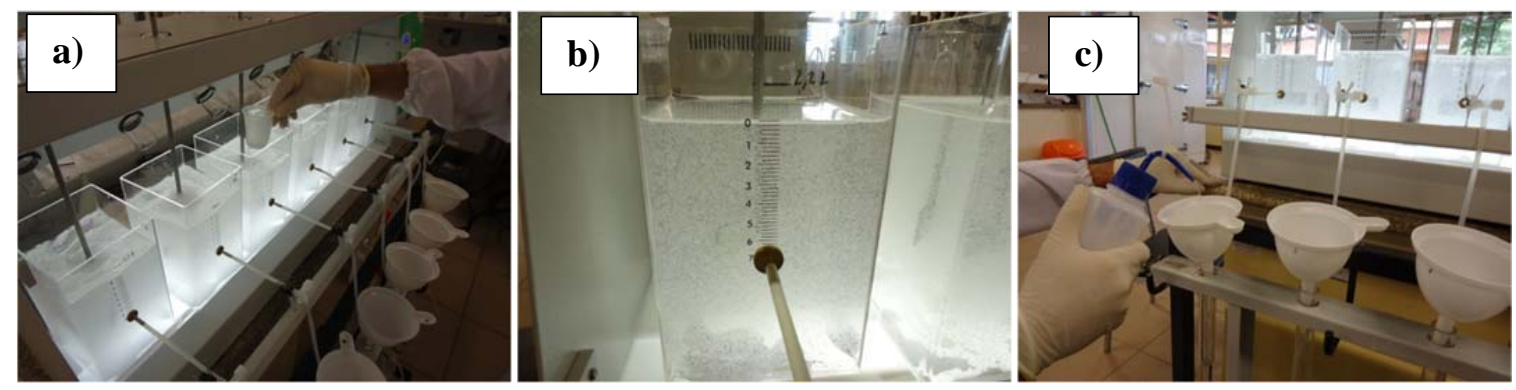

Figura 4.13- a) Retirada de amostra para leitura de $\mathrm{pH}$ e Potencial Zeta no fim da mistura rápida; b) início da formação de flocos no ensaio em jarteste; c) lavagem descendente dos FLAs com água deionizada entre a floculação e decantação

Após atingir a velocidade de sedimentação prevista, a água clarificada era encaminhada aos FLAs. A taxa inicial de filtração foi mantida em, aproximadamente, $100 \mathrm{~m}^{3} \cdot \mathrm{m}^{-2} \mathrm{~d}^{-1}-$ valor próximo a uma condição real. Para filtrar todo volume de água decantada proveniente do ensaio (perto de 1,0L por jarro), demandava-se quase $50 \mathrm{~min}$. Todos os cuidados eram tomados visando manter a taxa de filtração constante. 
O efluente de cada um dos FLAs era coletado em Erlenmeyer de 2L (Figura 4.14 a e b), previamente enxaguado com solução Tween $80,0,1 \%$. A amostra era processada pelo método descrito no item 4.4.1.

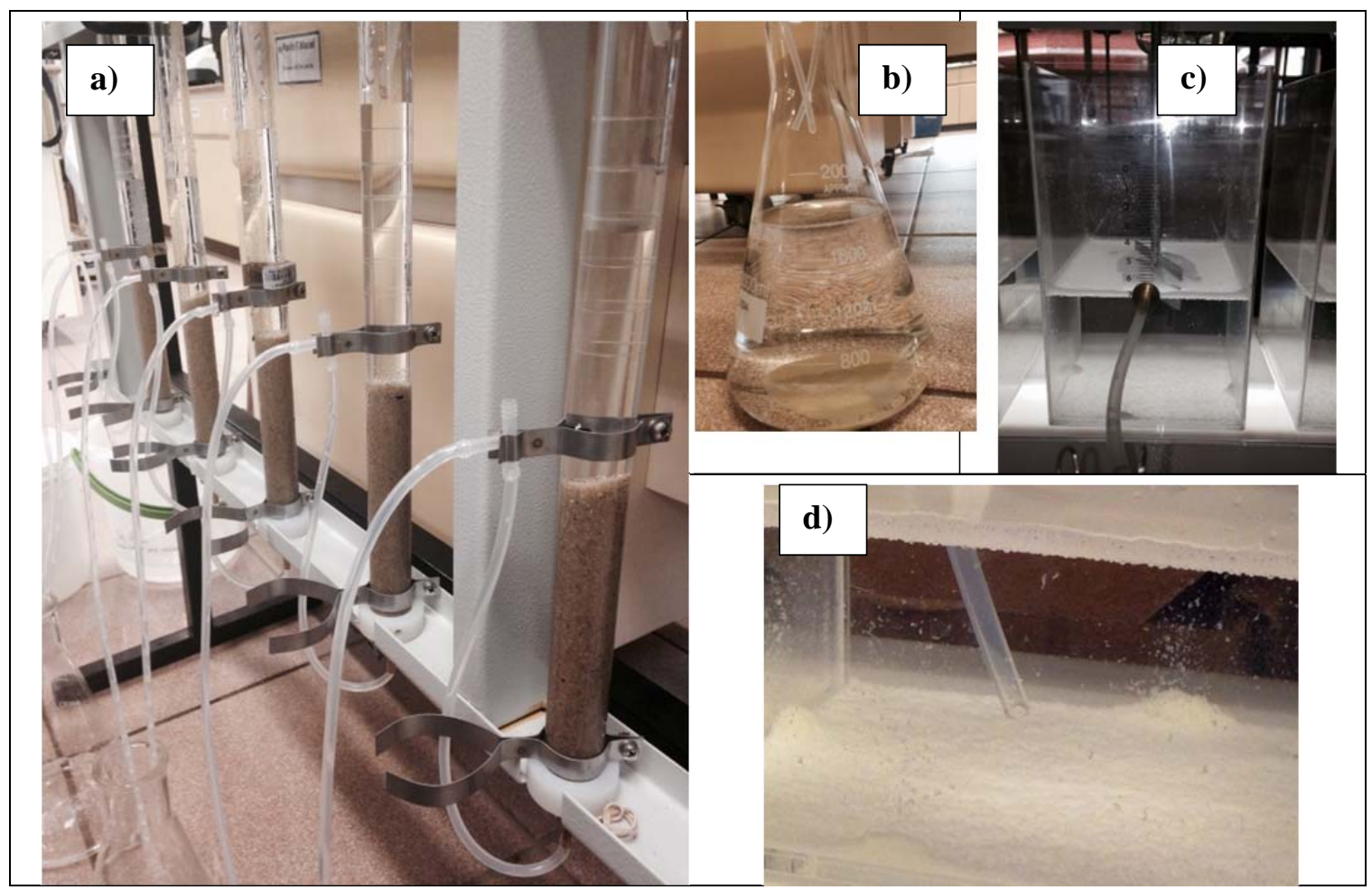

Figura 4.14- a) Coleta da água efluente dos FLAs por Erlenmeyers de 2 litros; b) detalhe de Erlenmeyer recebendo a água efluente dos FLAs c) Jarro após encaminhamento da água para os FLAs, água decantada abaixo do furo; d) coleta da água decantada, acima do lodo

Os jarros do jarteste possuem seus orifícios de coleta da água decantada no nível marcado de 1L. Toda água que estivesse abaixo do orifício e acima da região de formação de lodo era cuidadosamente retirada para a quantificação dos (oo)cistos (Figura 4.14-d). Considerou-se, para efeitos práticos, que a água que permanecia abaixo do orifício de saída de cada jarro possuía qualidade semelhante à água que era encaminhada para o filtro de laboratório. No entanto, sabe-se que o longo período de decantação ao qual esta água é submetida impossibilita caracterizar esta água rigorosamente como tal.

O lodo no fundo do jarro também era coletado e encaminhado à análise. Para a ressuspensão do lodo do tratamento (material que ficava sedimentado ao fundo dos jarros), adicionava-se água deionizada, com o auxílio de uma pisseta plástica. Direcionava-se a água nas paredes dos jarros com o objetivo de levar à suspensão (oo)cistos eventualmente aderidos 
à estas paredes. $\mathrm{O}$ volume era reunido em um ou três jarros (um jarro para a primeira condição de coagulação estudada, assim, todo lodo da amostra composta era ressuspedido em 2 litros; três para a segunda condição, pois neste caso o lodo era mais denso, o que dificultava o procedimento de concentração de protozoários, neste último caso, todo lodo da amostra composta era ressuspedido em 6 litros).

Acrescenta-se que o procedimento de concentração de protozoários para amostras de lodo ocorreu com utilização do método de filtração em membranas. No entanto, de forma diferente das outras amostras, onde todo volume de água era filtrado nas membranas, as amostras de lodo exigiram um grande número de membranas para que fossem integralmente concentradas. Este fato representou extensa rotina laboratorial, o que inviabilizaria a já alta carga de trabalho do procedimento em escala de bancada, padronizou-se, assim, o limite de 3 membranas para filtrar amostras de lodo. A consequência disso foi que uma fração do volume era analisada e isso foi considerado para o cálculo dos organismos retidos no lodo, conforme fator de correção - FC da Equação 3.

Dessa forma, era possível se fazer uma estimativa da porcentagem de microrganismos presentes em cada fase do tratamento.

O desempenho na remoção de protozoários foi avaliado em função dos resultados obtidos nas amostras de água filtrada. Destaca-se que cuidados foram tomados para que, em ensaios repetitivos, não existisse acumulação de protozoários no meio filtrante, o que geraria interferências nos resultados. Nesse contexto, a areia foi lavada conforme descrito no item 4.2, a permanência em estufa a $100^{\circ} \mathrm{C}$ por mais de 24 horas era indispensável.

Considerou-se, no início da pesquisa, a utilização de ozônio como pós-tratamento, com o propósito da inativação dos protozoários que ultrapassassem as barreiras de tratamento propostas. Entretanto, o volume final produzido nos testes em escala de bancada era baixo, o que fez com que o número de organismos identificados ao fim de cada ensaio de filtração fosse ínfimo ou inexistente. Este fato inviabilizou a realização de ensaios de oxidação com ozônio.

\subsection{ANÁLISES DE VARIÁVEIS FÍSICAS E QUÍMICAS}

As seguintes análises foram realizadas no acompanhamento do desempenho do sistema de tratamento em escala de bancada (Jarteste) para a remoção de cistos de Giardia spp. e oocistos de C. parvum, que podem ser observadas na Tabela 4.1. As análises seguiram o Standard Methods for the Examination of Water and Wastewater (APHA, 2012). 
Tabela 4.1- Equipamentos e métodos empregados para análise das variáveis físicas e químicas

\begin{tabular}{|c|c|c|c|}
\hline & Variável & \multicolumn{2}{|c|}{ Método e Equipamento } \\
\hline \multirow{9}{*}{$\begin{array}{c}\text { Análises de rotina - } \\
\text { LATAR }\end{array}$} & Alcalinidade total & \multicolumn{2}{|c|}{ Titulação potenciométrica com ácido sulfúrico até pH } \\
\hline & & \multicolumn{2}{|c|}{ 4,30 (método 2320B) } \\
\hline & Condutividade & \multicolumn{2}{|c|}{ Zetasizer Nano - ZS90 } \\
\hline & Cor aparente $(455 \mathrm{~nm})$ & \multicolumn{2}{|c|}{ Espectofotômetro DR 2800} \\
\hline & $\mathrm{pH}$ & \multicolumn{2}{|c|}{ 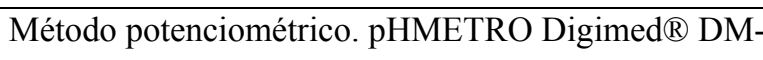 } \\
\hline & & \multicolumn{2}{|c|}{20} \\
\hline & Potencial Zeta & \multicolumn{2}{|c|}{ Zetasizer Nano - ZS90 } \\
\hline & Temperatura & \multicolumn{2}{|c|}{ Termômetro de mercúrio } \\
\hline & Turbidez & \multicolumn{2}{|c|}{ Turbidímetro HACH® $2100 \mathrm{P}$} \\
\hline \multirow{8}{*}{$\begin{array}{c}\text { Análises do } \\
\text { Laboratório de } \\
\text { Saneamento }\end{array}$} & Alumínio & \multirow{2}{*}{ Método $3111 \mathrm{D}$} & \\
\hline & Cálcio & & \\
\hline & Cádmo & \multirow{2}{*}{\multicolumn{2}{|c|}{ Fast sequencial }} \\
\hline & Chumbo & & \\
\hline & Ferro & \multirow[t]{3}{*}{ Método $3111 \mathrm{~B}$} & Atomic absorption - \\
\hline & Manganês & & \multirow[t]{3}{*}{ AA $240 \mathrm{FS}$} \\
\hline & Magnésio & & \\
\hline & Mercúrio & Método 3112 B & \\
\hline \multirow{7}{*}{$\begin{array}{c}\text { Análises do } \\
\text { Laboratório de } \\
\text { Saneamento }\end{array}$} & Coliformes totais & \multirow[t]{2}{*}{ Método 2923 B } & \multirow[t]{2}{*}{ Colilert $\AA$} \\
\hline & Escherichia coli & & \\
\hline & Dureza & Método $2340 \mathrm{C}$ & Titulação \\
\hline & Condutividade elétrica & Método $2510 \mathrm{~B}$ & Condutivímetro \\
\hline & & & Digimed DM-32 \\
\hline & Nitrogênio Nitrato & Método $4500 \mathrm{NO}_{3}^{-} \mathrm{B}$ & Espectofotômetro \\
\hline & Nitrogênio Nitrito & Método $4500 \mathrm{NO}_{2}^{-} \mathrm{B}$ & U.V. visível \\
\hline
\end{tabular}

\subsection{ANÁlise ESTATÍSTICA}

A análise estatística de comparação de médias foi realizada pelo teste ANOVA (One Way Analysis of Variance), por meio da análise de dados do programa MS Excel. 


\subsection{CONSTRUÇÃo DE MODELO MULTI-VARIÁVEIS PARA A TRANSMISSÃo DE GIARDIOSE E CRIPTOSPORIDIOSE}

O problema ocorrência de doenças de veiculação hídrica pode ser analisado por meio de ciclos que envolvam componentes específicos do contaminante biológico. Para a compreensão do tema, o estudo deve ser multidisciplinar e considerar variáveis envolvidas e fatores que influenciem estas variáveis. Buscou-se, neste estudo, a construção de um modelo, baseado no conceito do pensamento sistêmico, que resumisse a transmissão da giardiose e criptosporidiose por meio de varáveis básicas. Os passos para a construção deste modelo são enumerados abaixo:

1) Definição do problema: infecção de pessoas (ocorrência de giardiose e criptosporidiose).

2) Definição de variáveis que influenciem diretamente o problema principal: ingestão de águas servidas por serviço de tratamento de água deficiente, ingestão de alimentos contaminados e contaminação pessoa-a-pessoa.

3) Definição dos efeitos ou possibilidade de influência do problema principal.

4) Montagem da retroalimentação com múltiplas variáveis de influência.

5) Introdução de componentes externos à retroalimentação que possam influenciar as variáveis do ciclo.

As variáveis diretamente relacionadas foram conectadas por setas, de forma que a base da seta dizia respeito à "variável causa" e a ponta da seta à "variável efeito". Inicialmente, o modelo foi concebido em rascunhos manuscritos, pois a organização harmoniosa de todos componentes é uma tarefa que demanda repetições.

Nesse tipo de abordagem, uma variável pode estar conectada à várias outras. No presente estudo, o fator “contaminação de mananciais" está ligado à 7 variáveis de influência, por exemplo.

O termo variável é exaustivamente repetido, pois a intenção do modelo proposto é indicar que um componente pode aumentar ou diminuir outro. Por isso, a escolha dos termos para expressão da variável é um passo sensível. Por exemplo, um dos componentes do modelo é "eficácia no tratamento de água". Entende-se que a maior presença de (oo)cistos na água de captação faz com que haja maior possibilidade de insucesso do sistema em servir águas livres destes patógenos, o que tornaria o tratamento menos eficaz. Caso o termo escolhido fosse “eficiência no tratamento de água”, uma maior presença de patógenos na água de captação 
poderia se relacionar a maior eficiência do tratamento de água, já que a eficiência pode ser medida como uma razão entre a entrada e saída de protozoários. 


\section{RESULTADOS E DISCUSSÃO}

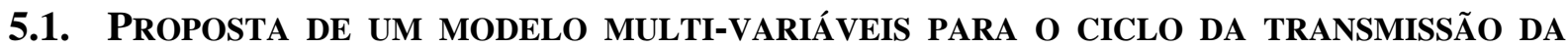 GIARDIOSE E CRIPTOSPORIDIOSE}

A problemática da transmissão da giardiose e da criptosporidiose pode ser analisada sob a ótica do pensamento sistêmico. O pensamento sistêmico é uma abordagem desenvolvida para enxergar um problema como um conjunto completo formado pelas conexões e variáveis em uma ou mais voltas de retroalimentação (SENGE,1990³ apud GRIFFITH, 2008 ). As voltas são desenhadas na forma de círculos de causalidade.

A Figura 5.1 apresenta um esquema simplificado da problemática da transmissão da giardiose e criptosporidiose sob a abordagem do pensamento sistêmico. Esta é uma ferramenta que permite uma visão global e não linear do sistema e pode auxiliar os tomadores de decisão.

O ciclo é formado por variáveis de influência, e uma maneira de analisar possibilidades de ação é o isolamento de uma variável do sistema com a observação de componentes que a modificam diretamente. No caso do tema estudado, a variável "contaminação de mananciais" se apresenta como forte determinante do problema pelo grande número de interações com outros componentes. A Tabela 5.1 apresenta causas e efeitos da "contaminação de mananciais" na questão da transmissão de criptosporidiose e giardiose.

Tabela 5.1- Variáveis relacionadas diretamente à contaminação de mananciais por cistos de Giardia e oocistos de Cryptosporidium

\begin{tabular}{ll}
\hline Variáveis causas (produtores) & Variáveis efeitos (produtos) \\
\hline - Escoamento de esgotos domésticos contaminados (mesmo & - Irrigação com águas impróprias na \\
sentido) & agricultura (mesmo sentido) \\
- Escoamento de fezes de animais contaminados (mesmo & - Captação de águas contaminadas para o \\
sentido) & tratamento (mesmo sentido) \\
- Escoamento de resíduos de ETA contaminados (mesmo & - Infecção de animais domésticos (mesmo \\
sentido) & sentido) \\
- Políticas sobre uso dos recursos hídricos (sentido oposto, p.e., & \\
mais políticas, menos contaminação) & \\
\hline
\end{tabular}

${ }^{3}$ SENGE, P.M. A quinta disciplina: arte, teoria e prática da organização de aprendizagem. 12. ed. São Paulo, SP: Best Seller, 1990. 


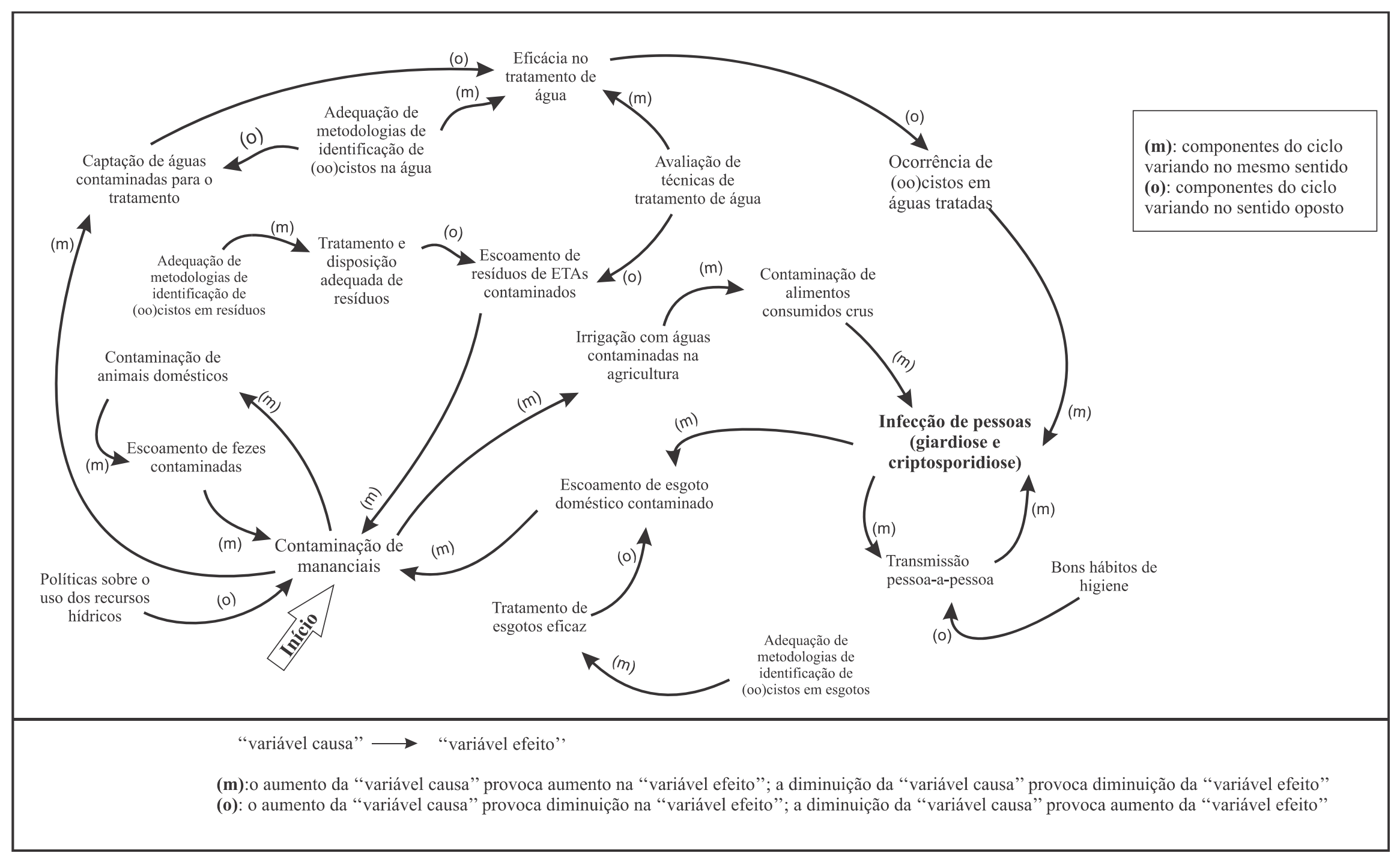

Figura 5.1- Pensamento sistêmico aplicado ao problema da transmissão da giardiose e criptosporidiose 
Nota-se que existem duas possibilidades de relação entre variáveis na abordagem do pensamento sistêmico. Na primeira, de mesmo sentido (“m”), o aumento de uma variável provoca aumento de outra variável diretamente relacionada; ainda, a diminuição de uma variável provoca a diminuição de outra variável. $\mathrm{Na}$ outra relação possível, a de sentido oposto ("o"), a diminuição de uma variável provoca aumento de outra variável, diretamente relacionada, e, ainda, o aumento de uma variável provoca diminuição de outra variável. Para esta segunda relação, tem-se como exemplo: o aumento de tratamento de esgotos eficaz diminui o escoamento de esgoto doméstico contaminado aos mananciais.

\subsection{Preparação da ÁGUA de estudo}

A Tabela 5.2 apresenta os resultados do ensaio de sedimentação em Cone Inhoff conforme metodologia de Campos (1980) adaptada por Di Bernardo (2004), descrito em 4.1.1.

Tabela 5.2- Ensaios de sedimentação da caulinita em Cone Inhoff para a obtenção da turbidez de água matriz conforme metodologia indicada em Di Bernardo (2004).

\begin{tabular}{ccc}
\hline $\begin{array}{c}\text { Tempo de sedimentação } \\
\text { (horas) }\end{array}$ & $\begin{array}{c}\text { Turbidez do } \\
\text { sobrenadante (uT) }\end{array}$ & Volume de sedimento (mL.L $\left.\mathbf{~}^{-\mathbf{1}}\right)$ \\
\hline 0,5 & 235 & 180 \\
\hline 1 & 168 & 150 \\
\hline 1,5 & 168 & 140 \\
\hline 2 & 157 & 165 \\
\hline 4 & 134 & 105 \\
\hline 6 & 122 & 103 \\
\hline 7,41 & 110 & 101 \\
\hline 9,6 & 103 & 96 \\
\hline 23 & 80 & 90 \\
\hline 24 & 75 & 90 \\
\hline 25 & 70 & 90 \\
\hline 26,5 & 71 & \\
\hline
\end{tabular}

Em Di Bernardo (2004) observou-se que o volume de sedimento era crescente com relação ao tempo. No ensaio realizado (Tabela 5.2) ocorreu a compactação do sedimento; assim, o volume medido $\left(\mathrm{mL} . \mathrm{L}^{-1}\right)$ era cada vez menor ao longo do tempo. No ensaio realizado 
em Cone Imhoff foi, igualmente, constatado um baixo valor de turbidez do sobrenadante estabilizado (fase final do ensaio) - diferente de $100 \mathrm{uT}$.

Os resultados supracitados indicaram um grande consumo de caulinita para obter 500L de água de estudo. Esse achado revelou a inviabilidade técnica e econômica da aplicação da metodologia de Campos (1980) adaptada por Di Bernardo (2004).

Neste contexto, o método escolhido para a preparação da água de estudo foi a aplicação direta de caulinita à água do poço. A Tabela 5.2 mostra os resultados do ensaio que tinha como objetivo a determinação de massa de caulinita necessária para que se atingisse a turbidez de $100 \mathrm{uT}$. Os resultados indicaram um valor aproximado de 0,1 gramas de caulinita por litro de água do poço.

Tabela 5.3- Ensaios de definição da massa de caulinita em função da turbidez para 2,0 L de água do poço da EESCC/USP

\begin{tabular}{ccc}
\hline $\begin{array}{c}\text { Massa de caulinita (g) } \\
\text { para cada } 2 \text { litros }\end{array}$ & $\begin{array}{c}\text { Turbidez medida na mistura (uT) após 2h de agitação } \\
\text { em Jarteste com rotação de 200 rpm. }\end{array}$ & $\begin{array}{c}\text { Média de } \\
\text { Turbidez (uT) }\end{array}$ \\
\hline 0,8 & 465 & 530 \\
0,8 & 557 & \\
0,8 & 569 & 268 \\
0,4 & 266 & \\
0,4 & 258 & 113 \\
0,4 & 280 & \\
\hline 0,2 & 101 & \\
0,2 & 115 & \\
0,2 & 125 & \\
\hline
\end{tabular}

A massa de caulinita foi estabelecida (100mg para cada litro) visando preparar, inicialmente, $500 \mathrm{~L}$ de água de estudo com turbidez próxima de $100 \mathrm{uT}$. A agitação da água de estudo foi realizada de forma manual, coletando-se amostras para aferição da turbidez. A agitação manual foi feita de forma padronizada, com 60 movimentos circulares não intensos. O procedimento era repetido a cada ato de coleta da água de estudo.

As águas de estudo e do poço, foram caracterizadas no Laboratório de Saneamento da EESC/USP. As características são apresentadas na Tabela 5.4. 
Tabela 5.4 - Características Físicas, Químicas e Microbiológicas nas Águas do Poço e de Estudo

\begin{tabular}{lccc}
\hline \multicolumn{1}{c}{ Variáveis } & Unidade & Água Poço & Água de Estudo \\
\hline Alcalinidade total & $\mathrm{mg} \mathrm{CaCO} \cdot \mathrm{L}^{-1}$ & 35 & 36 \\
Alumínio total & $\mathrm{mg} \mathrm{Al} \cdot \mathrm{L}^{-1}$ & $<0,01$ & 0,91 \\
Chumbo total & $\mathrm{mg} \mathrm{Pb} \cdot \mathrm{L}^{-1}$ & $<0,01$ & $<0,01$ \\
Cádmio total & $\mathrm{mg} \mathrm{Cd} \cdot \mathrm{L}^{-1}$ & $<0,0006$ & $<0,0006$ \\
Cálcio & $\mathrm{mg} \mathrm{Ca} \cdot \mathrm{L}^{-1}$ & 4,5 & 3,82 \\
Coliformes totais & $\mathrm{UFC} \cdot 100 \mathrm{~mL}^{-1}$ & 14 & 6,13 \\
Escherichia coli & $\mathrm{UFC} \cdot 100 \mathrm{~mL}^{-1}$ & 2 & Ausente \\
Condutividade elétrica & $\mu \mathrm{S} \cdot \mathrm{cm}^{-1}$ & 54,16 & 53,75 \\
Dureza & $\mathrm{mg} \mathrm{CaCO} \cdot \mathrm{L}^{-1}$ & 16 & 14 \\
Ferro total & $\mathrm{mg} \mathrm{Fe} \cdot \mathrm{L}^{-1}$ & 0,034 & 0,037 \\
Manganês total & $\mathrm{mg} \mathrm{Mn} \cdot \mathrm{L}^{-1}$ & 0,008 & 0,008 \\
Magnésio total & $\mathrm{mg} \mathrm{Mg} \cdot \mathrm{L}^{-1}$ & 1,474 & 1,445 \\
Mercúrio total & $\mathrm{mg} \mathrm{Hg} \cdot \mathrm{L}^{-1}$ & $\mathrm{Não} \mathrm{medido}$ & $<0,0001$ \\
Nitrogênio como nitrato & $\mathrm{mg} \mathrm{N}-\mathrm{NO}_{3} \cdot \mathrm{L}^{-1}$ & $<0,10$ & 0,05 \\
Nitrogênio como nitrito & $\mathrm{mg} \mathrm{N}-\mathrm{NO}_{2} \cdot \mathrm{L}^{-1}$ & $<0,001$ & 0,005 \\
Turbidez & $\mathrm{uT}$ & 0,41 & 125 \\
\hline
\end{tabular}

A análise de metais se configurou importante devido à investigação de possíveis interferentes no método de identificação de protozoários.

\subsection{ENSAIOS DE TRATABILIDADE EM ESCALA DE BANCADA}

Os parâmetros iniciais de mistura (rápida e lenta), de velocidade de sedimentação e de taxa de filtração foram adotados, como primeira aproximação, conforme resultados obtidos por Corrêa et al.(2005), De Julio et al. (2010), Ferrari et al. (2011), e; Pavinelli (2001). Estes trabalhos também empregaram o cloreto de polialumínio (PAC) como coagulante. A Tabela 5.5 apresenta os valores inicialmente testados.

Os ensaios foram realizados para quatro velocidades de sedimentação (Vs) distintas e os resultados são apresentados na Figura 5.2 e na Figura 5.3. A linha indicada nas figuras representa a região em que a turbidez remanescente foi de até 5,0 uT - valor de referência na 
água decantada a ser encaminhada à filtração, segundo Di Bernardo e Sabogal Paz (2008). Os diagramas estão expressos em termos de eficiência de remoção de turbidez.

Tabela 5.5 - Parâmetros Iniciais dos Ensaios de Tratabilidade

\begin{tabular}{ll}
\hline Parâmetro & Valores adotados \\
\hline Dosagem de PAC $\left(\mathrm{mg} . \mathrm{L}^{-1}\right)$ com $18 \%{\mathrm{de} \mathrm{Al}_{2} \mathrm{O}_{3}}$ & $5 \mathrm{a} 60$ \\
pH de coagulação & $5 \mathrm{a} 9$ \\
Gradiente médio de velocidade mistura rápida $\left(\mathrm{s}^{-1}\right)-\mathrm{G}_{\mathrm{mr}}$ & 1000 \\
Tempo de mistura rápida $(\mathrm{s})-\mathrm{T}_{\mathrm{mr}}$ & 10 \\
Gradiente médio de velocidade na floculação $\left(\mathrm{s}^{-1}\right)-\mathrm{G}_{\mathrm{f}}$ & 30 \\
Tempo de floculação (min) $-\mathrm{T}_{\mathrm{f}}$ & 20 \\
\hline
\end{tabular}

A análise das Figura 5.2 e Figura 5.3 permitiu definir as melhores condições de dosagem e $\mathrm{pH}$ de coagulação a serem inicialmente testadas. Essas condições foram: i) dosagem de $20 \mathrm{mg} . \mathrm{L}^{-1}$ sem adição de alcalinizante (ou acidificante) com $\mathrm{pH}$ em torno de 7,0; e ii) dosagem de $55 \mathrm{mg} . \mathrm{L}^{-1} \mathrm{com} \mathrm{pH}$ de aproximadamente 7,2 , com adição de alcalinizante. Os pontos foram selecionados em função do melhor desempenho na remoção de turbidez.

$\mathrm{Na}$ Figura 5.3-b) pode-se verificar que a velocidade de sedimentação de 4,0 $\mathrm{cm} . \mathrm{min}^{-1}$ não favoreceu o tratamento da água de estudo porque não houve turbidez remanescente de até 5uT na água decantada.

$\mathrm{Na}$ sequência foram otimizados os parâmetros em estudo, segundo a metodologia descrita em Di Bernardo et al (2011), iniciando pela mistura rápida. As condições testadas foram: i) $\mathrm{G}_{\mathrm{mr}}=800,900,1000$ e $1100 \mathrm{~s}^{-1}$; e ii) $\mathrm{T}_{\mathrm{mr}}=10,15,20,25$ e $30 \mathrm{~s}$. Os resultados são apresentados na Figura 5.4, para as duas dosagens previstas - $20 \mathrm{mg} . \mathrm{L}^{-1}$ e $55 \mathrm{mg} . \mathrm{L}^{-1}$, respectivamente. $\mathrm{O}$ gradiente de velocidade de $1100 \mathrm{~s}^{-1}$ não foi avaliado para a dosagem de 55 mg. $\mathrm{L}^{-1}$ devido ao seu mau desempenho nos primeiros testes. 


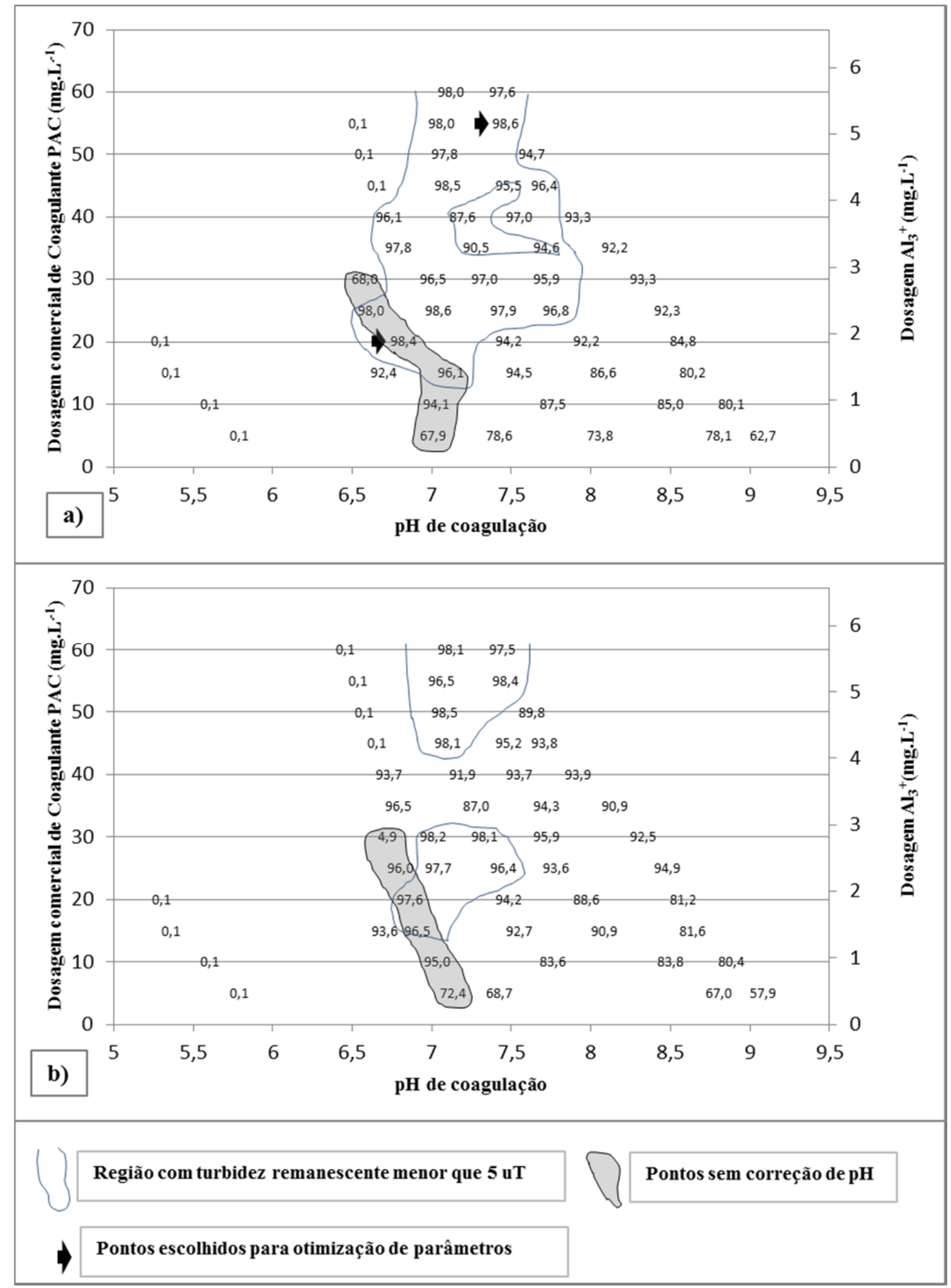

Figura 5.2- Diagramas de coagulação utilizando PAC, para uma água de estudo com turbidez em torno de $100 \mathrm{uT}$, expresso em termos de porcentagem de remoção de turbidez, para as seguintes condições: $\mathrm{G}_{\mathrm{mr}}=1000 \mathrm{~s}^{-1}, \mathrm{~T}_{\mathrm{mr}}=10 \mathrm{~s}, \mathrm{G}_{\mathrm{f}}=30 \mathrm{~s}^{-1}, \mathrm{~T}_{\mathrm{f}}=20 \mathrm{~min}$. a) $\mathrm{Vs}=1,5$ cm.min ${ }^{-1}$;) $\mathrm{Vs}=2,0 \mathrm{~cm} \cdot \mathrm{min}^{-1}$ 


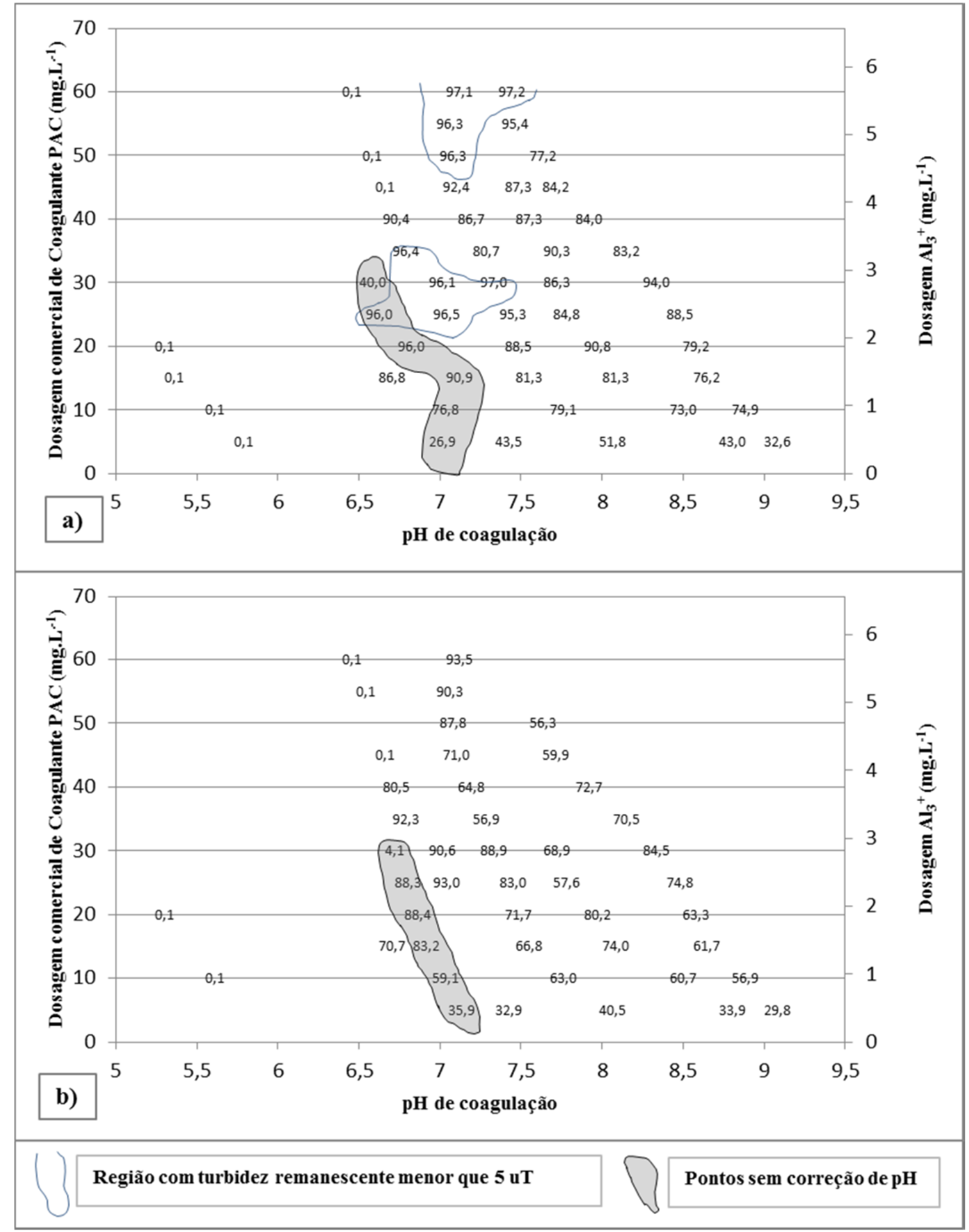

Figura 5.3- - Diagramas de coagulação utilizando PAC, para uma água de estudo com turbidez em torno de 100 uT, expresso em termos de porcentagem de remoção de turbidez, para as seguintes condições: $\mathrm{G}_{\mathrm{mr}}=1000 \mathrm{~s}^{-1}, \mathrm{~T}_{\mathrm{mr}}=10 \mathrm{~s}, \mathrm{G}_{\mathrm{f}}=30 \mathrm{~s}^{-1}, \mathrm{~T}_{\mathrm{f}}=20 \mathrm{~min}$. a) $\mathrm{Vs}=3,0$ cm.min ${ }^{-1}$;) $\mathrm{Vs}=4,0 \mathrm{~cm} \cdot \mathrm{min}^{-1}$ 


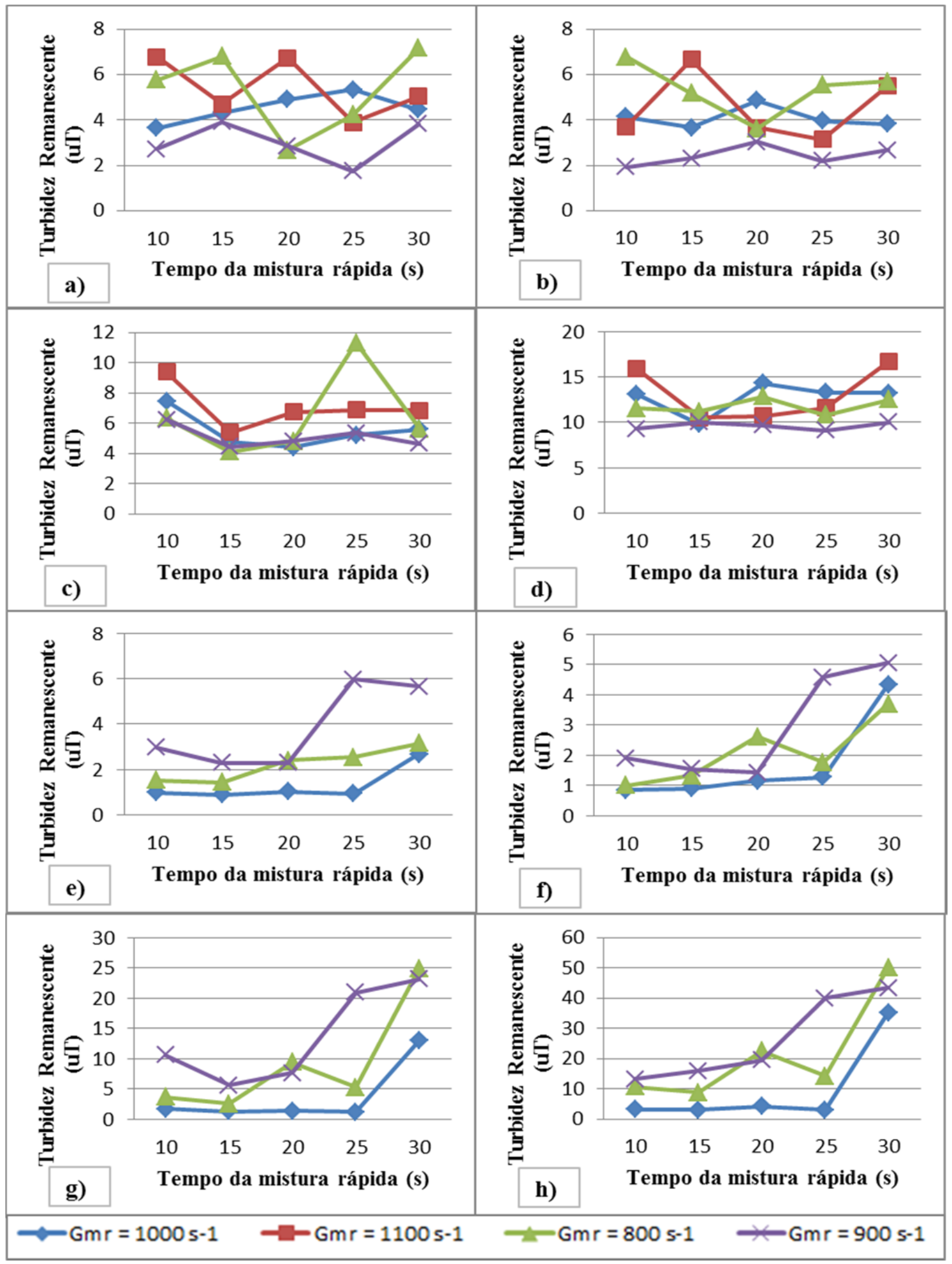

Figura 5.4- Turbidez da água decantada em função das condições de mistura rápida (tempo e gradiente). Condições: $\mathrm{T}_{\mathrm{f}}=20 \mathrm{~min}, \mathrm{G}_{\mathrm{f}}=30 \mathrm{~s}^{-1}$. a) até d), dosagem de PAC $=20 \mathrm{mg} \cdot \mathrm{L}^{-}$ ${ }^{1}$ e $\mathrm{pH} \cong 7$. e) até h), dosagem de $\mathrm{PAC}=55 \mathrm{mg} \cdot \mathrm{L}^{-1}$ e $\mathrm{pH} \cong 7,2$. a) $\mathrm{Vs}=1,5 \mathrm{~cm} \cdot \mathrm{min}^{-1}$; b) $\mathrm{Vs}=2,0$ cm. $\min ^{-1}$; c) $\mathrm{Vs}_{\mathrm{s}}=3,0 \mathrm{~cm} \cdot \mathrm{min}^{-1}$; d) $\mathrm{Vs}=4,0 \mathrm{~cm} \cdot \mathrm{min}^{-1}$; e) $\mathrm{Vs}=1,5 \mathrm{~cm} \cdot \mathrm{min}^{-1}$; f) $\mathrm{Vs}=2,0 \mathrm{~cm} \cdot \mathrm{min}^{-}$ ${ }^{1}$; g) $\mathrm{Vs}=3,0 \mathrm{~cm} \cdot \mathrm{min}^{-1}$; h) $\mathrm{Vs}=4,0 \mathrm{~cm} \cdot \mathrm{min}^{-1}$ 
Os próximos ensaios visaram otimizar a mistura lenta. Os gradientes médios de velocidade fixados, em cada ensaio, foram 20, 30 e $40 \mathrm{~s}^{-1}$ com tempos de mistura de 10, 15, 20, 25 e 30 min. Os resultados são apresentados na Figura 5.5 para as duas dosagens testadas $-20 \mathrm{mg} / \mathrm{L}$ e $55 \mathrm{mg} / \mathrm{L}$, respectivamente.

A Figura 5.4 indica que as melhores condições de mistura rápida foram: i) $G_{m r}=900 \mathrm{~s}^{-1}$ e $\mathrm{T}_{\mathrm{mr}}=15 \mathrm{~s}$, para dosagem de $20 \mathrm{mg} \cdot \mathrm{L}^{-1}$; e ii) $\mathrm{G}_{\mathrm{mr}}=1000 \mathrm{~s}^{-1}$ e $\mathrm{T}_{\mathrm{mr}}=15 \mathrm{~min}$, para dosagem de $55 \mathrm{mg} . \mathrm{L}^{-1}$. A Figura 5.5 indica que as melhores condições de mistura lenta foram: i) $\mathrm{G}_{\mathrm{f}}=30 \mathrm{~s}^{-1}$ e $\mathrm{T}_{\mathrm{f}}=20 \mathrm{~min}$, para dosagem de $20 \mathrm{mg} \cdot \mathrm{L}^{-1}$; e ii) $\mathrm{G}_{\mathrm{f}}=20 \mathrm{~s}^{-1}$ e $\mathrm{T}_{\mathrm{f}}=20 \mathrm{~min}$, para dosagem de 55 mg. $\mathrm{L}^{-1}$.

Em função das melhores condições estabelecidas, foi possível a realização dos diagramas de coagulação definitivos, para cada velocidade de sedimentação estudada, conforme Figuras 5.6 e 5.7. A linha indicada nas figuras representa a região em que a turbidez remanescente foi de até 5,0 uT - valor de referência da água decantada a ser encaminhada à filtração, segundo Di Bernardo e Sabogal Paz (2008).

Em função dos dados das Figuras 5.6 e 5.7, determinaram-se dois pontos “ótimos”, para a velocidade de sedimentação de $2,0 \mathrm{~cm} / \mathrm{min}$, de interesse ao estudo: i) dosagem de $25 \mathrm{mg} / \mathrm{L}$ e pH de coagulação 6,95 (sem adição de alcalinizante); e ii) dosagem de $65 \mathrm{mg} / \mathrm{L}$ e pH de coagulação 7,21 (com adição de $15 \mathrm{mg} / \mathrm{L}$ de hidróxido de sódio). Os pontos, indicados com setas na Figura 5.6 b, foram selecionados em função da maior eficiência na remoção de turbidez.

Observa-se que no diagrama definitivo referente à velocidade de sedimentação de 4,0 $\mathrm{cm} \cdot \mathrm{min}^{-1}$ (Figura $5.7 \mathrm{~b}$ ) houve regiões em que a turbidez remanescente fora inferior a $5 \mathrm{uT}$. Esta constatação representa clara melhora das condições de coagulação diante do emprego dos parâmetros otimizados, estabelecidos nas Figuras 5.4 e 5.5.

A capacidade dos filtros de laboratório - FLAs em reduzir a turbidez foi avaliada segundo Tabela 5.6. Os resultados mostram que, independentemente da dosagem utilizada, a água filtrada atendeu o Padrão de Potabilidade (Portaria no 2914, 2011)

Avaliou-se também o comportamento do sistema quanto às outras variáveis físicas e químicas de qualidade da água. A Tabela 5.7 apresenta os resultados da análise de amostra composta da água efluente dos FLAs. 


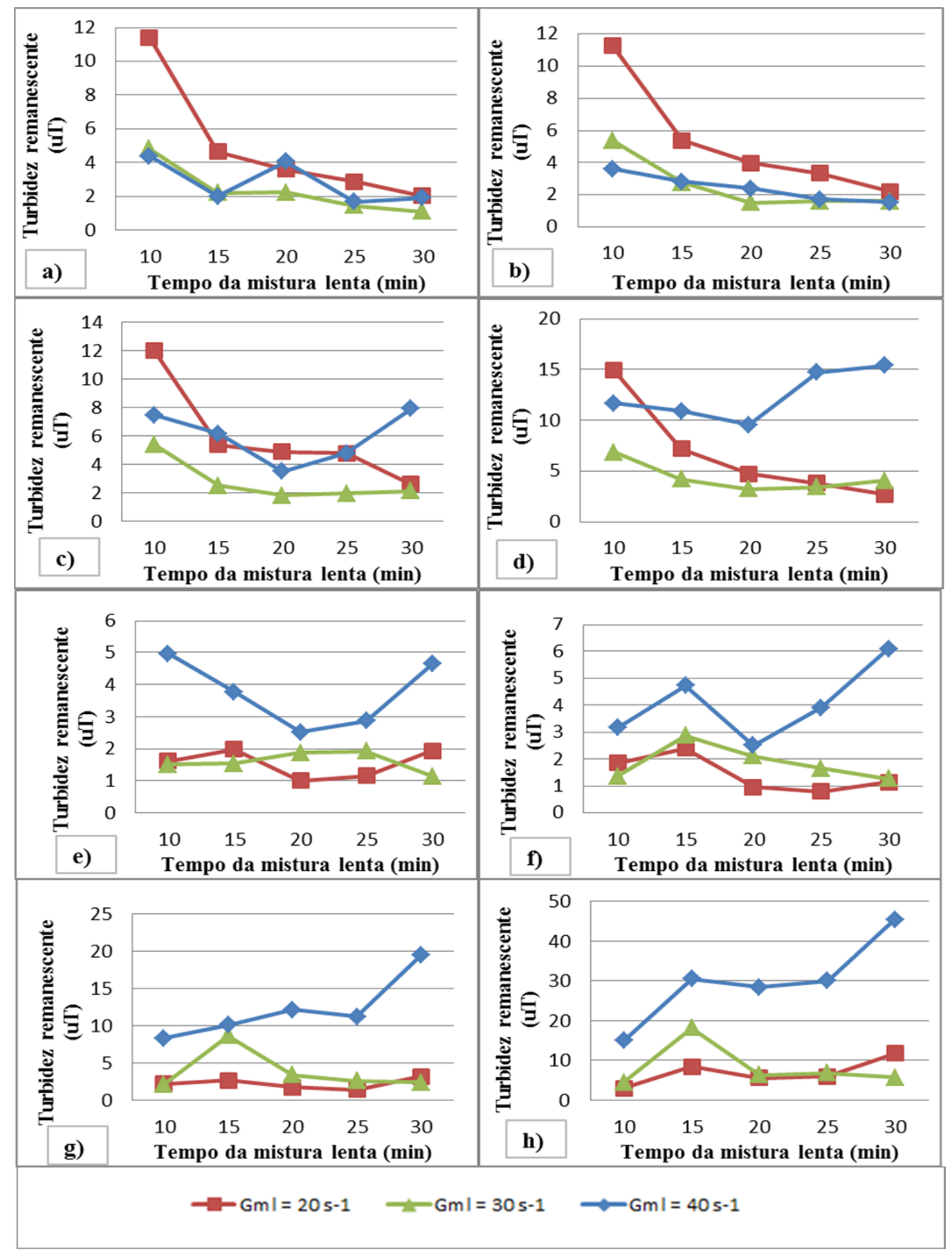

Figura 5.5- Turbidez da água decantada em função das condições de mistura lenta (tempo e gradiente). Condições: $\mathrm{T}_{\mathrm{mr}}=10 \mathrm{~s}, \mathrm{G}_{\mathrm{mr}}=1000 \mathrm{~s}^{-1}$. a) até d), dosagem de PAC $=20$ mg. $\mathrm{L}^{-1}$ e $\mathrm{pH} \cong 7$. e) até h), dosagem de $\mathrm{PAC}=55 \mathrm{mg} . \mathrm{L}^{-1}$ e $\mathrm{pH} \cong 7,2$. a) $\mathrm{Vs}=1,5 \mathrm{~cm} \cdot \mathrm{min}^{-1}$; b) $\mathrm{Vs}_{\mathrm{s}}=2,0 \mathrm{~cm} \cdot \mathrm{min}^{-1}$; c) $\mathrm{Vs}=3,0 \mathrm{~cm} \cdot \mathrm{min}^{-1}$; d) $\mathrm{Vs}=4,0 \mathrm{~cm} \cdot \min ^{-1}$; e) $\mathrm{Vs}=1,5 \mathrm{~cm} \cdot \mathrm{min}^{-1}$; f) $\mathrm{Vs}_{\mathrm{s}}=2,0$ $\mathrm{cm} \cdot \mathrm{min}^{-1}$; g) $\mathrm{Vs}=3,0 \mathrm{~cm} \cdot \mathrm{min}^{-1}$; e h) $\mathrm{Vs}=4,0 \mathrm{~cm} \cdot \mathrm{min}^{-1}$ 


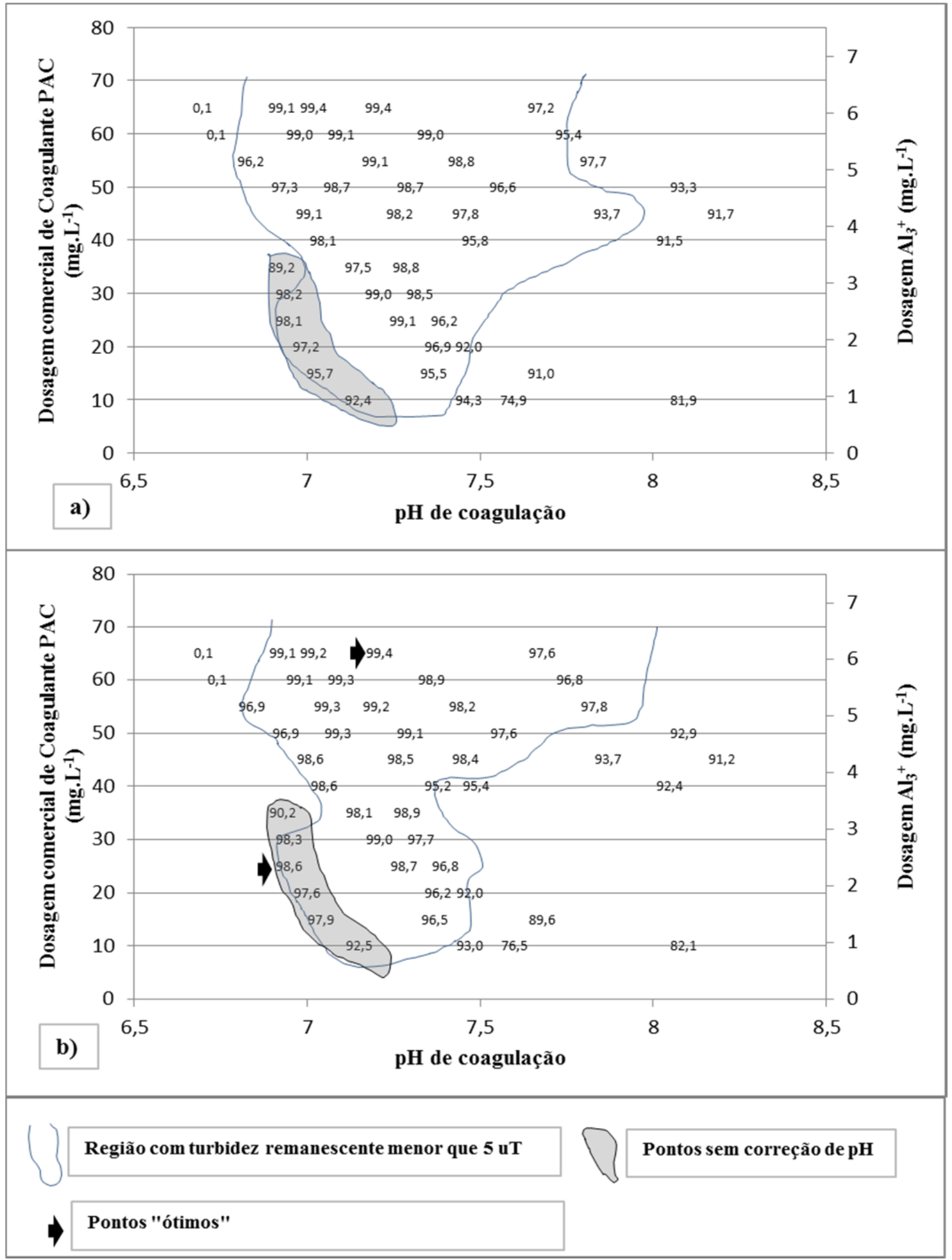

Figura 5.6- Diagramas de coagulação para água de estudo com turbidez em torno de $100 \mathrm{uT}$, expresso em termos de porcentagem de remoção de turbidez, utilizando PAC para as seguintes condições: i) dosagem de PAC entre 10 a $35 \mathrm{mg} / \mathrm{L}: \mathrm{G}_{\mathrm{mr}}=900 \mathrm{~s}^{-1}, \mathrm{~T}_{\mathrm{mr}}=15 \mathrm{~s}, \mathrm{G}_{\mathrm{f}}=$ $30 \mathrm{~s}^{-1}, \mathrm{~T}_{\mathrm{f}}=20 \mathrm{~min}$ e Vs $=1,5 \mathrm{~cm} \cdot \mathrm{min}^{-1}$; e ii) dosagem de PAC entre 40 a $65 \mathrm{mg} / \mathrm{L}: \mathrm{G}_{\mathrm{mr}}=1000$ $\mathrm{s}^{-1}, \mathrm{~T}_{\mathrm{mr}}=15 \mathrm{~s}, \mathrm{G}_{\mathrm{f}}=20 \mathrm{~s}^{-1}, \mathrm{~T}_{\mathrm{f}}=20 \mathrm{~min}$ e a) $\left.\mathrm{Vs}=1,5 \mathrm{~cm} \cdot \mathrm{min}^{-1} ; \mathbf{b}\right) \mathrm{Vs}=2,0 \mathrm{~cm} \cdot \mathrm{min}^{-1}$ 


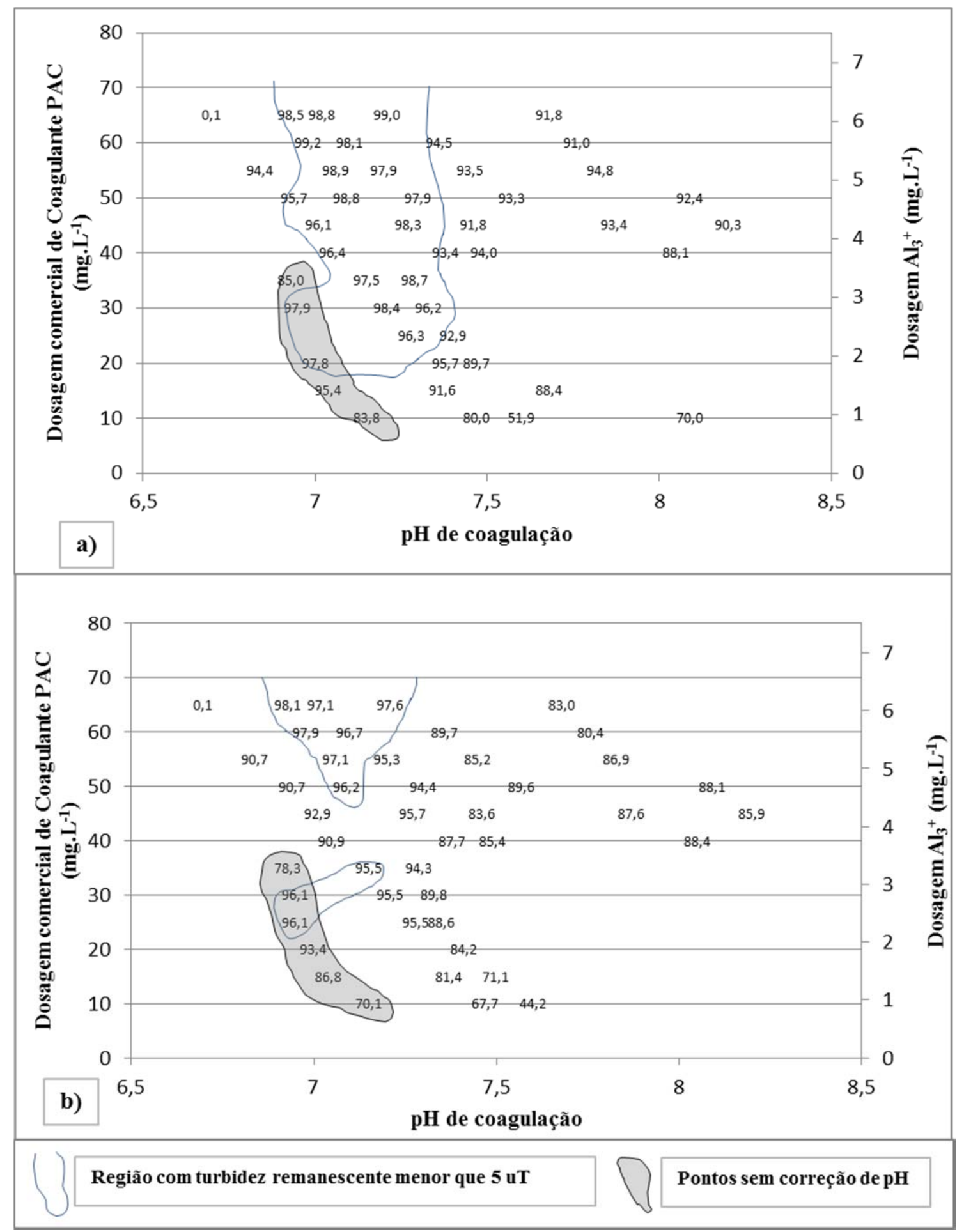

Figura 5.7- Diagramas de coagulação para água de estudo com turbidez em torno de $100 \mathrm{uT}$, expresso em termos de porcentagem de remoção de turbidez, utilizando PAC para as seguintes condições: i) dosagem de PAC entre 10 a $35 \mathrm{mg} / \mathrm{L}: \mathrm{G}_{\mathrm{mr}}=900 \mathrm{~s}^{-1}, \mathrm{~T}_{\mathrm{mr}}=15 \mathrm{~s}, \mathrm{G}_{\mathrm{f}}=$ $30 \mathrm{~s}^{-1}, \mathrm{~T}_{\mathrm{f}}=20 \mathrm{~min}$; ii) dosagem de PAC entre 40 a $65 \mathrm{mg} / \mathrm{L}: \mathrm{G}_{\mathrm{mr}}=1000 \mathrm{~s}^{-1}, \mathrm{~T}_{\mathrm{mr}}=15 \mathrm{~s}, \mathrm{G}_{\mathrm{f}}$ $=20 \mathrm{~s}^{-1}, \mathrm{~T}_{\mathrm{f}}=20 \mathrm{~min}$ e a) $\mathrm{Vs}=3,0 \mathrm{~cm} \cdot \mathrm{min}^{-1}$; e b) $\mathrm{Vs}=4,0 \mathrm{~cm} \cdot \mathrm{min}^{-1}$ 
Tabela 5.6- Turbidez efluente do FLA de acordo com a dosagem de coagulante PAC - todos os filtros possuíam condições idênticas de operação.

\begin{tabular}{ccc}
\hline \multirow{2}{*}{ Filtro } & \multicolumn{2}{c}{ Turbidez efluente dos FLA (uT) } \\
\cline { 2 - 3 } & Dosagem de coagulante (25 $\mathbf{~ m g . L ^ { - 1 } )}$ & Dosagem de coagulante (65 $\mathbf{~ m g . L ^ { - 1 } )}$ \\
\hline 1 & 0,47 & 0,33 \\
\hline 2 & 0,25 & 0,25 \\
\hline 3 & 0,29 & 0,34 \\
\hline 4 & 0,33 & 0,31 \\
\hline 5 & 0,27 & 0,28 \\
\hline 6 & 0,26 & 0,27 \\
\hline
\end{tabular}

Tabela 5.7- Características físicas, químicas e microbiológicas da água efluente dos FLAs

\begin{tabular}{|c|c|c|}
\hline Variável & Unidade & Água Filtrada \\
\hline Alcalinidade total & $\left(\mathrm{mg} \mathrm{CaCO}{ }_{3} \cdot \mathrm{L}^{-1}\right)$ & 20 \\
\hline Alumínio & (mg Al L-1) & $<0,001$ \\
\hline Chumbo & (mg Pb.L-1) & $<0,01$ \\
\hline Cádmio & (mg Cd.L-1) & $<0,0006$ \\
\hline Cálcio & (mg Ca.L-1) & 4,49 \\
\hline Coliformes Totais & (UFC.100 Ml-1) & Ausente \\
\hline Escherichia coli & $\left(\mathrm{UFC} .100 \mathrm{Ml}^{-1}\right)$ & Ausente \\
\hline Condutividade elétrica & $(\mu \mathrm{S} . c \mathrm{~m}-1)$ & 70,8 \\
\hline Cor & $(\mathrm{Pt}-\mathrm{Co})$ & $<1$ \\
\hline Dureza & (mg CaCO3.L-1) & 14 \\
\hline Ferro & (mg Fe.L-1) & $<0,005$ \\
\hline Manganês & (mg Mn.L-1) & $<0,003$ \\
\hline Magnésio & (mg Mg.L-1) & 1,517 \\
\hline Mercúrio & (mg Hg.L-1) & $<0,0001$ \\
\hline Nitrogênio - nitrato & (mg N-NO3.L-1) & $<0,01$ \\
\hline Nitrogênio - nitrito & (mg N-NO2.L-1) & $<0,001$ \\
\hline Turbidez & (NTU) & 0,24 \\
\hline
\end{tabular}

Desta forma, o sistema composto pelo aparelho Jarteste e FLAs estava apto para a realização dos ensaios de tratabilidade com inóculo de cistos de Giardia spp. e oocistos de $C$. parvum (conforme descrito no item 5.5). 


\subsection{ENSAIOS DE CONTROLE DA QUALIDADE DO MÉTODO DE IDENTIFICAÇÃO DE PROTOZOÁRIOS}

Os primeiros testes com água de estudo e inóculo de protozoários ocorreram com o uso do ColorSeed ${ }^{\circledR}$, conforme Tabela 5.8, sem a etapa de purificação por separação imunomagnética-IMS .

Tabela 5.8- Recuperação de (oo)cistos nos primeiros ensaios com ColorSeed ${ }^{\circledR}$ para água de estudo com turbidez elevada (129 uT), método de concentração por filtração em membranas e ausência de purificação por IMS

\begin{tabular}{cccccc}
\hline $\begin{array}{l}\text { Teste } \\
\left(\mathbf{N}^{\mathbf{0}}\right)\end{array}$ & $\begin{array}{c}\text { Volume } \\
\text { da alíquota } \\
(\boldsymbol{\mu L})\end{array}$ & Giardia spp. & $\begin{array}{c}\text { Enumeração } \\
\text { Cryptosporidium } \\
\text { spp. }\end{array}$ & $\begin{array}{c}\text { Porcentagem de recuperação } \\
\text { Giardia }\end{array}$ & $\begin{array}{c}\text { Cryptosporidium } \\
\text { spp. }\end{array}$ \\
\hline 1 & 50 & 0 & 0 & $0 \%$ & $0 \%$ \\
\hline 2 & 50 & 0 & 0 & $0 \%$ & $0 \%$ \\
\hline 3 & 10 & 1 & 0 & $100 \%$ & $0 \%$ \\
\hline 4 & 10 & 0 & 0 & $0 \%$ & $0 \%$ \\
\hline 5 & 10 & 1 & 3 & $100 \%$ & $300 \%$ \\
\hline
\end{tabular}

No teste $\mathrm{n}^{\mathrm{o}} 1$ foi observado que o tempo de secagem da amostra nos poços da lâmina, normalmente adotado em $30 \mathrm{~min}$, era insuficiente antes da adição dos outros reagentes necessários à preparação da lâmina para posterior leitura no microscópio, como observado por Medeiros (2010). Assim, em função da experiência supracitada, padronizou-se a secagem por um período overnight. A insuficiência no tempo de secagem se refletiu em impossibilidade de contagem de (oo)cistos na lâmina.

No teste $n^{\circ} 2$, observou-se que o volume de alíquota adotado para o teste $(50 \mu \mathrm{L})$ era muito grande - consequência da turbidez elevada da água de estudo. Isto gerou a formação de aspecto branco denso do poço da lâmina de microscopia, segundo Figura 5.8 a. No exame de microscopia em RID, observou-se uma densa camada de sólidos (Figura 5.8 b). Essa camada impedia a visualização dos (oo)cistos potencialmente presentes na lâmina, fato que impossibilitou a contagem. 

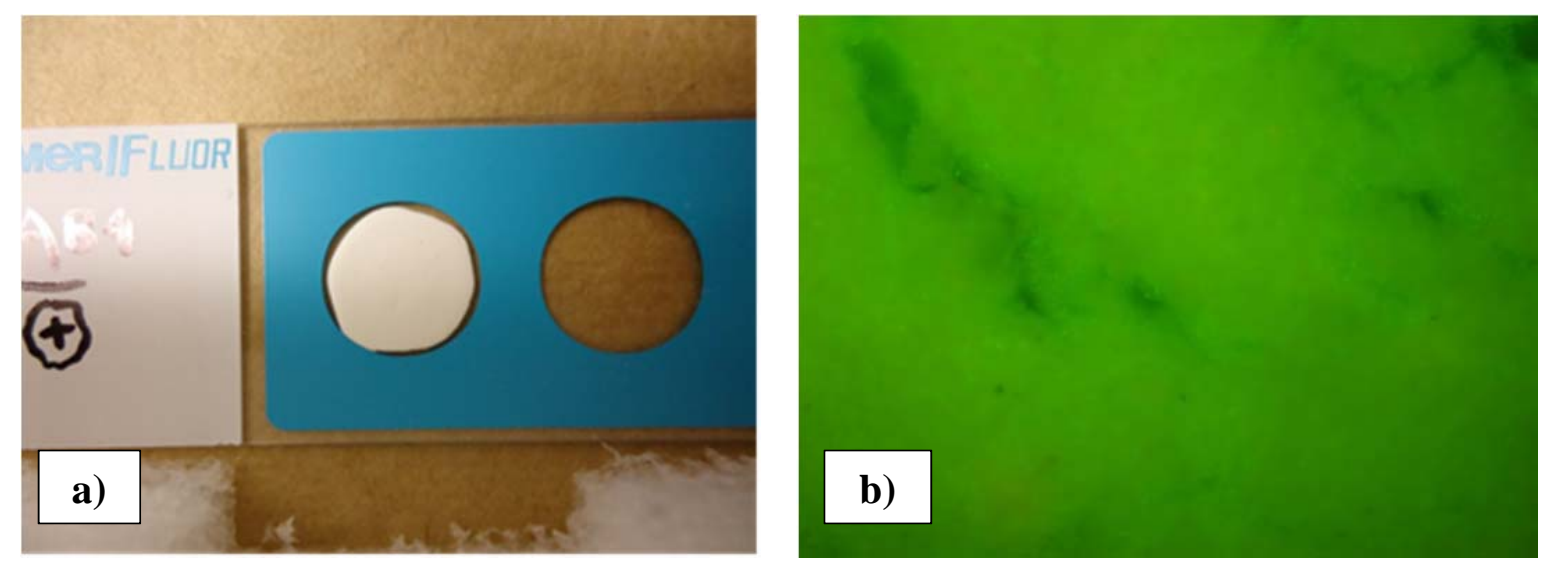

Figura 5.8- a) Aspecto do poço na lâmina de microscopia quando a alíquota do sedimento concentrado da água de estudo fora de $50 \mu \mathrm{L}$; b) visualização em RID do poço de lâmina de microscopia montado com alíquota de $50 \mu \mathrm{L}$

Optou-se então pela realização de exames com uma alíquota de volume menor (10 $\mu \mathrm{L})$, realizando-se 3 testes ( $n^{\circ} 3$ a 5) para se atestar a viabilidade de utilização desse volume. Os poços de lâminas de imunofluorescência montados apresentaram aspecto adequado no exame de microscopia, mostrando (oo)cistos facilmente identificáveis em RID (excitação $\lambda=450 \mathrm{a}$ $490 \mathrm{~nm}$ e barreira $\lambda=520 \mathrm{~nm})$, e confirmados em coloração vermelha no filtro WG ( $\lambda=510$ a $550 \mathrm{~nm}$ e barreira $\lambda=600$ a $660 \mathrm{~nm}$ ), conforme Figura 5.9. Não houve visualização de (oo)cistos no exame de fluorescência DAPI (excitação $\lambda=365$ a $400 \mathrm{~nm}$ e barreira $\lambda=395 \mathrm{~nm}$ ) nem em DIC nos testes realizados em água de estudo com turbidez elevada sem o procedimento de separação imunomagnética. Isto ocorreu pelo fato do poço da lâmina ser bastante espesso, com camadas sobrepostas, apesar da utilização de uma alíquota de volume pequeno $(10 \mu \mathrm{L})$.

Os testes $n^{\circ} 3$ a 5 permitiram a identificação dos (oo)cistos porque pôde ser atestada a coloração avermelhada dos mesmos na mudança, no microscópio, dos filtros de comprimento de onda para o vermelho - isto porque se tratava do inóculo ColorSeed ${ }^{\circledR}$ (Figura 5.9). Neste sentido, o uso deste tipo de inóculo é bem-vindo para os primeiros testes porque possui aspecto confirmatório adicional; contudo, o valor desse inoculo é duas vezes maior se comparado ao Easyseed $®$

A utilização de alíquotas de volume pequeno $(10 \mu \mathrm{L})$ apresenta o problema de pouca representatividade da mesma a partir do sedimento final de $1000 \mu \mathrm{L}$ (no caso de não haver IMS). Consequentemente, foram obtidas recuperações muito distintas entre os ensaios $n^{\circ} 3$ a 5. A recuperação média de cistos Giardia spp., nesses ensaios, foi de $67 \%$ e o coeficiente de 
variação de $87 \%$. Em relação aos oocistos de Cryptosporidium spp., a recuperação média foi de $100 \%$ e o coeficiente de variação de $173 \%$.
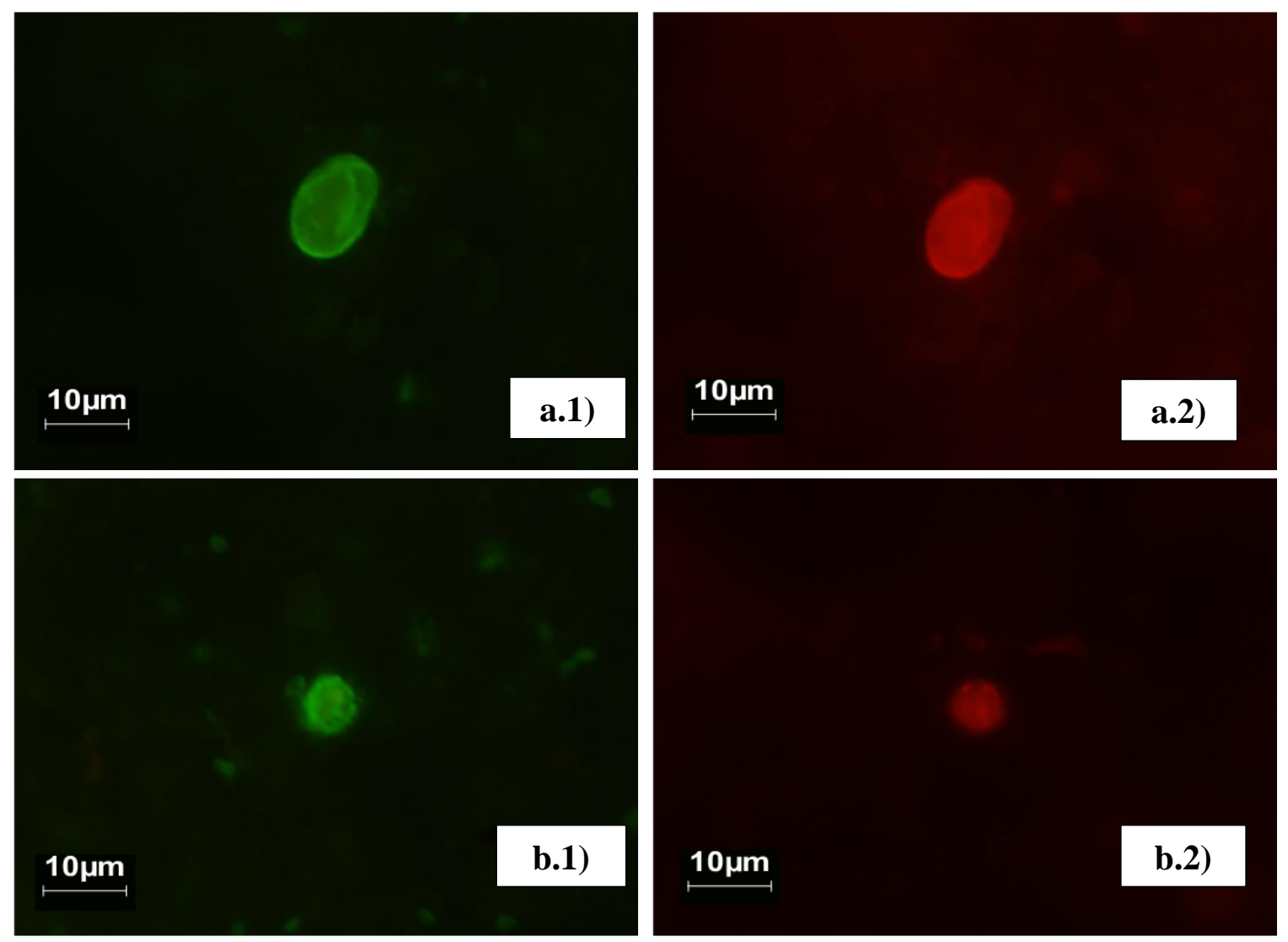

Figura 5.9- Cisto de Giardia spp. e oocisto de Cryptosporidium spp. nos testes preliminares de controle de qualidade; a.1) cisto de Giardia spp. em microscopia de fluorescência, filtro FITC (excitação $\lambda=450$ a $490 \mathrm{~nm}$ e barreira $\lambda=520 \mathrm{~nm}$ ); a.2) cisto de Giardia spp. em microscopia de fluorescência, filtro WG $(\lambda=510$ a $550 \mathrm{~nm}$ e barreira $\lambda=600$ a $660 \mathrm{~nm})$, presente na suspensão Color Seed®; b.1) oocisto de Cryptosporidium spp. em microscopia de fluorescência, filtro FITC; b.2) oocisto de Cryptosporidium spp. em microscopia de fluorescência, filtro WG, presente na suspensão Color Seed ${ }^{\circledR}$. (aumento de 400x)

Com os resultados preliminares, verificou-se que para a água de estudo, o uso de alíquota com volume superior a $10 \mu \mathrm{L}$ era inviável quando não era prevista a purificação com IMS. No entanto, o volume de $10 \mu \mathrm{L}$ apresenta-se como pouco representativo em relação ao sedimento final de $1000 \mu \mathrm{L}$. Optou-se, então, por dividir o sedimento de uma amostra em 5 alíquotas de $10 \mu \mathrm{L}$ cada, totalizando $50 \mu \mathrm{L}$ por amostra.

Uma segunda série de testes foi realizada com o procedimento de separação imunomagnética (IMS). Os testes foram realizados em quadriplicatas em condições idênticas. 
Inicialmente, adotando-se o método de dissociação térmica em aparelho de banho seco para a separação dos (oo)cistos das microesferas magnéticas. Os resultados encontram-se na Tabela 5.9 (testes 6 a 9). Nestes testes o inóculo utilizado foi o EasySeed ${ }^{\circledR}$.

A metodologia de separação imunomagnética com dissociação térmica, mostrou-se inadequada na pesquisa. Nos testes $n^{\circ} 6$ a 9 não foram encontrados oocistos de Cryptosporidium spp. e os organismos anotados como cistos de Giardia spp. não apresentavam a coloração verde-maçã fluorescente característica e o aspecto confirmatório indispensável para a identificação do organismo, segundo Figura 5.10. Yakub (2000) encontrou cistos de Giardia spp. exibindo coloração de vermelho brilhante a vermelho tijolo na microscopia de fluorescência em FITC, em matriz com alta concentração de ferro. Outras formas diferentes encontradas ao longo na pesquisa são apresentadas no APÊNDICE.
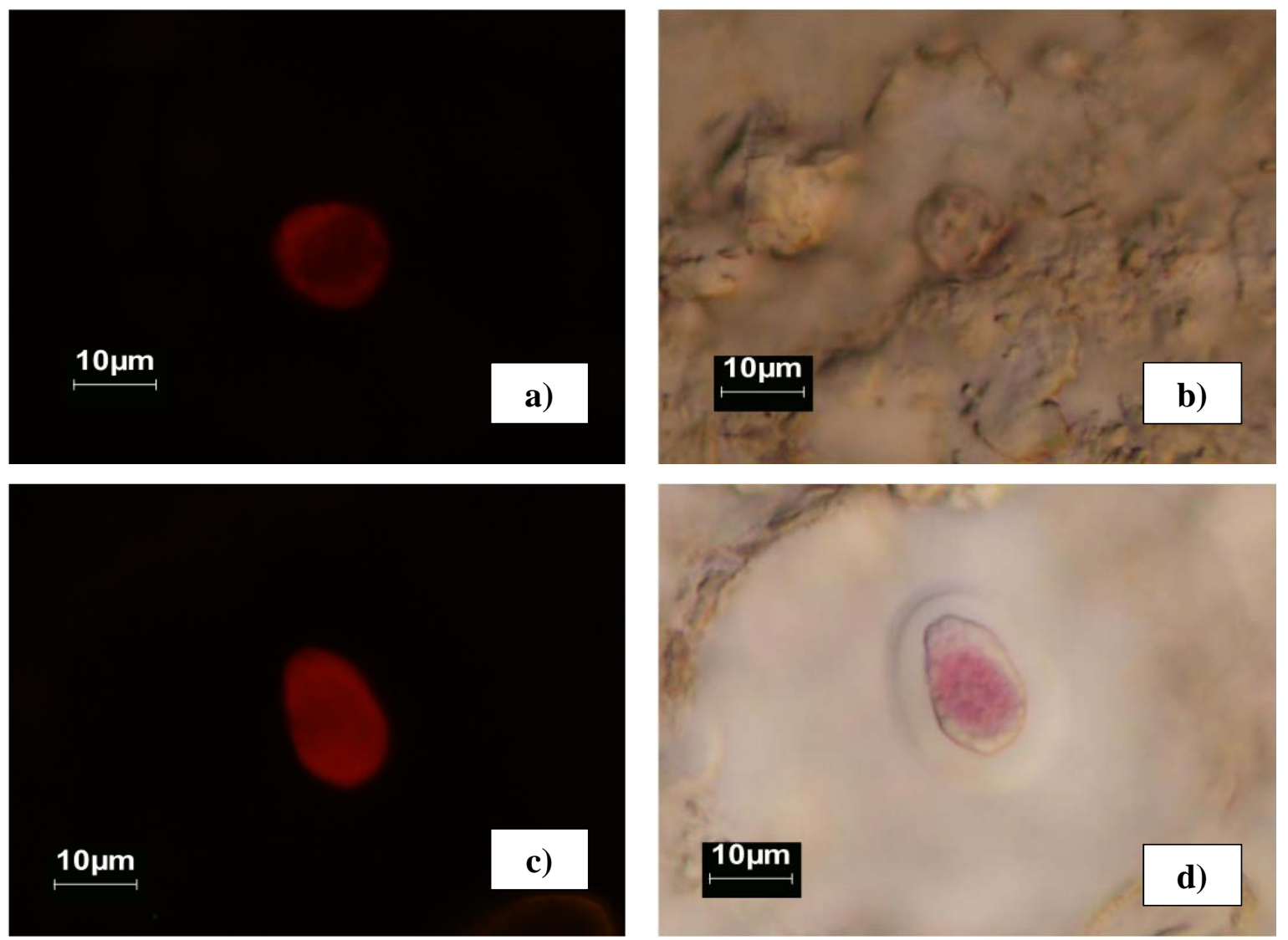

Figura 5.10- Estruturas com características semelhantes aos cistos Giardia spp. a) estrutura 1 visualizada em fluorescência em FITC (excitação $\lambda=450$ a $490 \mathrm{~nm}$ e barreira $\lambda=$ $520 \mathrm{~nm})$ b) estrutura 1 visualizada em DIC; c) estrutura 2 visualizada em fluorescência em FITC; d) estrutura 2 visualizada em microscopia DIC - (aumento de $400 \mathrm{x}$ ) 
Os resultados dos testes $n^{\circ} 6$ a 9 indicaram alguma interferência das características físico-químicas da água de estudo em relação ao método. A primeira interpretação dos resultados foi que a dissociação não aconteceu no aparelho de banho seco. Assim, realizou-se mais um teste, com inóculo EasySeed ${ }^{\circledR}$ e IMS, utilizando-se um aparelho de banho-maria para realizar a dissociação térmica (Tabela 5.9).

Tabela 5.9- Recuperação de (oo)cistos para água de estudo (matriz com turbidez elevada 126 uT) e água reagente (Milli-Q), método de concentração de protozoários por filtração em membranas em testes com separação imunomagnética, em dissociação ácida ou térmica

\begin{tabular}{|c|c|c|c|c|c|c|}
\hline \multirow{2}{*}{$\begin{array}{l}\text { Teste } \\
\left(\mathbf{N}^{\circ}\right)\end{array}$} & \multirow{2}{*}{$\begin{array}{c}\text { Tipo de } \\
\text { dissociação }\end{array}$} & \multirow{2}{*}{$\begin{array}{c}\text { Volume da } \\
\text { alíquota }(\mu \mathrm{L})\end{array}$} & \multicolumn{2}{|c|}{ Enumeração } & \multicolumn{2}{|c|}{$\begin{array}{c}\text { Porcentagem de } \\
\text { recuperação }\end{array}$} \\
\hline & & & $\begin{array}{c}\text { Giardia } \\
\text { spp. }\end{array}$ & $\begin{array}{c}\text { Cryptosporidu } \\
\text { m spp. }\end{array}$ & $\begin{array}{c}\text { Giardia } \\
\text { spp. }\end{array}$ & $\begin{array}{c}\text { Cryptosporidu } \\
\text { m spp. }\end{array}$ \\
\hline \multicolumn{7}{|c|}{ Água de estudo (matriz com turbidez elevada 126 ut) } \\
\hline 6 & \multirow{5}{*}{ Térmica } & 10 & 2 & 0 & $20 \%$ & 0 \\
\hline 7 & & 10 & 1 & 0 & $10 \%$ & 0 \\
\hline 8 & & 10 & 1 & 0 & $10 \%$ & 0 \\
\hline 9 & & 10 & 2 & 0 & $20 \%$ & 0 \\
\hline 10 & & 10 & 0 & 0 & 0 & 0 \\
\hline 11 & Ácida & 100 & 10 & 0 & $10 \%$ & 0 \\
\hline \multicolumn{7}{|c|}{ Água reagente (Milli-Q) } \\
\hline 12 & \multirow{4}{*}{ Ácida } & 50 & 5 & 0 & $10 \%$ & 0 \\
\hline 13 & & 50 & 7 & 0 & $14 \%$ & 0 \\
\hline 14 & & 50 & 0 & 0 & 0 & 0 \\
\hline 15 & & 50 & 0 & 0 & 0 & 0 \\
\hline
\end{tabular}

No teste $\mathrm{n}^{\mathrm{o}} 10$, observa-se que não houve recuperação de (oo)cistos quando se realizou o procedimento de IMS com dissociação térmica por banho-maria.

Nos testes $n^{\circ} 6$ a 10 verificou-se que não houve efetiva recuperação de (oo)cistos, segundo os padrões estabelecidos, quando se realizou o procedimento de IMS com 
dissociação térmica. Em função dos resultados, optou-se pela realização da dissociação ácida. $\mathrm{O}$ primeiro teste foi realizado com água de estudo e uma alíquota de $100 \mu \mathrm{L}$. O resultado também está na Tabela 5.9.

$\mathrm{O}$ ensaio $\mathrm{n}^{\mathrm{o}} 11$ foi realizado com ácido diluído a $0,1 \mathrm{~N}$ preparado no Laboratório LATAR, o qual não era um ácido padronizado rastreável como recomendado no Método 1623.1 - talvez esse fato gerou, como consequência, baixa recuperação de (oo)cistos. Além disso, o volume de alíquota $(100 \mu \mathrm{L}, 50 \mu \mathrm{L}$ de cada uma das duas dissociações) utilizado mostrou-se inadequado, pois extravasava no poço da lâmina.

Em função dos resultados do ensaio $\mathrm{n}^{\mathrm{o}} 11$, decidiu-se utilizar a metade desse volume nos próximos testes com dissociação ácida. Ainda, com a hipótese de algum tipo de interferente na água de estudo ao método IMS, realizou-se testes com água purificada (MilliQ) - testes $n^{\circ} 12$ e 13 .

A partir dos resultados da Tabela 5.9, concluiu-se que o ácido utilizado estava inadequado, pois a recuperação de cistos de Giardia spp. era baixa e não houve recuperação de oocistos de Cryptosporidium spp. Realizou-se, então, mais dois testes (n ${ }^{\circ} 14$ e 15) com ácidos padronizados no laboratório LATAR e, novamente, esses testes não apresentaram recuperação de nenhum dos organismos estudados.

\subsubsection{ENSAIOS DE CONTROLE DE QUALIDAdE DO MÉTODO DE IDENTIFICAÇÃo DE PROTOZOÁRIOS SEM O USO DO PROCEDIMENTO DE SEPARAÇÃO IMUNOMAGNÉTICA (IMS)}

Os ensaios preliminares de controle de qualidade indicaram ser adequado utilizar 5 alíquotas de $10 \mu \mathrm{L}$ cada para cada amostra de água de estudo com turbidez elevada. $\mathrm{O}$ primeiro foi realizado com ColorSeed ${ }^{\circledR}$ (teste 16), o resultado está na Tabela 5.10.

A recuperação de cistos de Giardia spp. foi satisfatória neste primeiro teste; no entanto, a recuperação de oocistos de Cryptosporidium spp. ainda era baixa. O Método 1623.1 exige que se realizem 4 testes para o controle da qualidade da metodologia. Os 3 testes restantes (testes 17 a 19) foram realizados com o EasySeed ${ }^{\circledR}$, os resultados se encontram na Tabela 5.10 .

Os resultados dos testes de controle de qualidade sem realizar a etapa de purificação por separação imunomagnética indicam: para cistos Giardia spp., eficiência média de recuperação de $80 \%$ com coeficiente de variação de 20,5\%; para oocistos de Cryptosporidium spp., eficiência média de recuperação de $10 \%$ e coeficiente de variação de $115 \%$. 
O método utilizado demonstrou-se aceitável quanto à recuperação de cistos de Giardia spp., o mesmo não aconteceu quanto aos oocistos de Cryptosporidium spp. Este fato se deve principalmente ao padrão de coloração mais fraco e tamanho bem inferior dos oocistos de Cryptosporidium spp. quando comparado aos cistos de Giardia spp. A Figura 5.11 mostra uma comparação entre cistos e oocistos em uma lâmina montada com a solução de controle positivo contida do kit Merifluor ${ }^{\circledR}$.

Tabela 5.10- Recuperação de (oo)cistos para água de estudo (matriz com turbidez elevada 126 uT), método de concentração de protozoários por filtração em membranas em testes sem separação imunomagnética, com disposição de alíquotas em 5 poços de lâminas de imunofluorescênia

\begin{tabular}{ccccc}
\hline $\begin{array}{c}\text { Teste } \\
\mathbf{N}^{\mathbf{0}}\end{array}$ & Giardia spp. & Cryptosporidum spp. & Giardia spp. & Cryptosporidum spp. \\
\hline 16 & 4 & 1 & $80 \%$ & $20 \%$ \\
17 & 5 & 0 & $100 \%$ & $0 \%$ \\
18 & 4 & 1 & $80 \%$ & $20 \%$ \\
19 & 3 & 0 & $60 \%$ & $0 \%$ \\
\hline
\end{tabular}

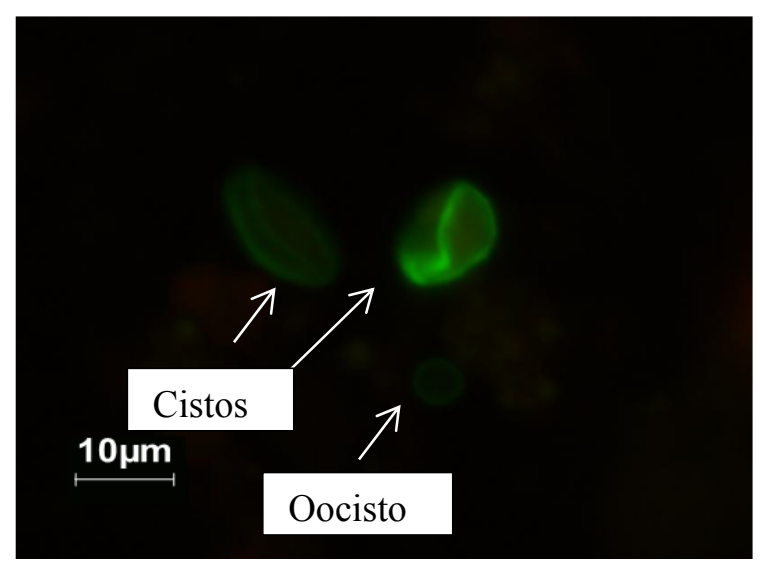

Figura 5.11- Cistos de Giardia spp oocisto de Cryptosporidium spp. (suspensão controle positivo do kit Merifluor ${ }^{\circledR}$ ), visualizados em um mesmo campo (aumento de 400x)

A ausência do procedimento de separação imunomagnética traz duas implicações importantes. A primeira é número mínimo detectável elevado. Para estes testes, utilizando 5 
poços de microscopia por amostra, o número mínimo detectável foi de 20 organismos, ou seja, cada organismo visualizado na etapa de microscopia representava 20 da amostra concentrada. Este é um fator de erro considerável.

A segunda implicação diz respeito à qualidade da imagem visualizada na microscopia de fluorescência. A amostra concentrada em questão (água de estudo com turbidez aumentada por caulinita) apresentou um sedimento branco muito denso. Esta observação permite inferir a possibilidade da existência de oocistos de Cryptosporidium spp. nas amostras em que eles não foram contabilizados, possivelmente mascarados pelo denso sedimento concentrado.

Outro efeito observado em decorrência da segunda implicação foi a impossibilidade de análise na microscopia de fluorescência DAPI e na microscopia DIC. A análise qualitativa das amostras provenientes de água de estudo com turbidez elevada ficou, portanto, restrita à microscopia de fluorescência no comprimento de onda do FITC.

\subsubsection{ENSAIOS DE CONTROLE DA QUALIDADE DO MÉTODO DE IDENTIFICAÇÃo DE PROTOZOÁRIOS COM O USO DA SEPARAÇÃO IMUNOMAGNÉTICA}

Os testes de controle de qualidade com a aplicação da separação imunomagnética foram considerados utilizando a dissociação ácida. Ácidos e álcalis rastreáveis (marca Specsol®) foram empregados na etapa de dissociação, conforme recomendação do Método 1623.1. Os resultados destes testes encontram-se na Tabela 5.11.

Tabela 5.11- Recuperação de (oo)cistos para água de estudo (matriz com turbidez elevada 120 uT), método de concentração de protozoários por filtração em membranas em testes com separação imunomagnética e dissociação ácida

\section{Enumeração $\quad$ Porcentagem de recuperação}

\section{Teste N $^{\mathbf{0}}$ Giardia spp. Cryptosporidum spp. Giardia spp. Cryptosporidum spp.}

\begin{tabular}{lllll}
\hline 20 & 37 & 9 & $37 \%$ & $9 \%$ \\
21 & 31 & 3 & $31 \%$ & $3 \%$ \\
22 & 37 & 8 & $37 \%$ & $8 \%$ \\
23 & 21 & 3 & $21 \%$ & $3 \%$ \\
\hline
\end{tabular}

A recuperação média para cistos de Giardia spp. foi de $32 \%$ e o coeficiente de variação de $24 \%$. Para oocistos de Cryptosporidium spp., obteve-se uma recuperação média de 6\% e 
um coeficiente de variação de $56 \%$. Novamente, o método mostrou-se aceitável para a recuperação de cistos de Giardia spp. e, repetidamente, impróprio para a recuperação de oocistos de Cryptosporidium spp.

Para estas análises, de forma diferente aos testes preliminares, fez-se a dissociação ácida em 2 etapas, aplicando-se as amostras provenientes de cada dissociação em diferentes poços de lâmina de imunofluorescência. Esta separação acarretou o incremento de um teste do kit Merifluor ${ }^{\circledR}$ por amostra analisada. Os resultados mostraram-se consistentes e foi possível observar o papel da segunda dissociação ácida na recuperação de (oo)cistos.

A melhor visualização dos protozoários durante a leitura ao microscópio foi evidente. Neste sentido, foi possível confirmar aspectos morfológicos empregando-se a DIC bem como a coloração com DAPI (Figura 5.12).

Os testes de controle de qualidade mostraram que a recuperação de cistos de Giardia spp. foi melhor sucedida que a de oocistos de Cryptosporidium spp. Este fato foi recorrente nos testes com e sem separação imunomagnética. Uma comparação entre os dois métodos indicou que quando não se realizou a separação imunomagnética, os resultados são mais consistentes quantitativamente, pois houve maior porcentagem de recuperação para este caso. Contudo, não foi possível realizar os dois seguintes testes confirmatórios: DIC e exame de fluorescência DAPI. As amostras apresentavam camadas densas de sólidos, não se visualizava o (oo)cisto identificado na RID quando se mudava os filtros do microscópio para comprimento de onda referente ao exame de fluorescência DAPI, o mesmo acontecendo para DIC.

A realização da separação imunomagnética é vantajosa no sentido de que a amostra é integralmente analisada, o que dispensou a tomada de alíquotas, potencial fator de erro. No entanto, o método é acrescido de vários passos, fonte de perda de (oo)cistos. Para o caso da recuperação de oocistos de Cryptosporidium spp. foi notável a melhora, com IMS, quanto ao coeficiente de variação, ainda que este valor esteja acima do que é estabelecido no Método 1623.1.

A Tabela 5.12 sintetiza os resultados do controle de qualidade inicial das metodologias empregadas para a identificação de (oo)cistos. A decisão quanto ao emprego da metodologia de identificação de protozoários com e sem a separação imunomagnética deve considerar fatores como a complexidade operacional, o tempo da análise e, sobretudo, a viabilidade financeira. 

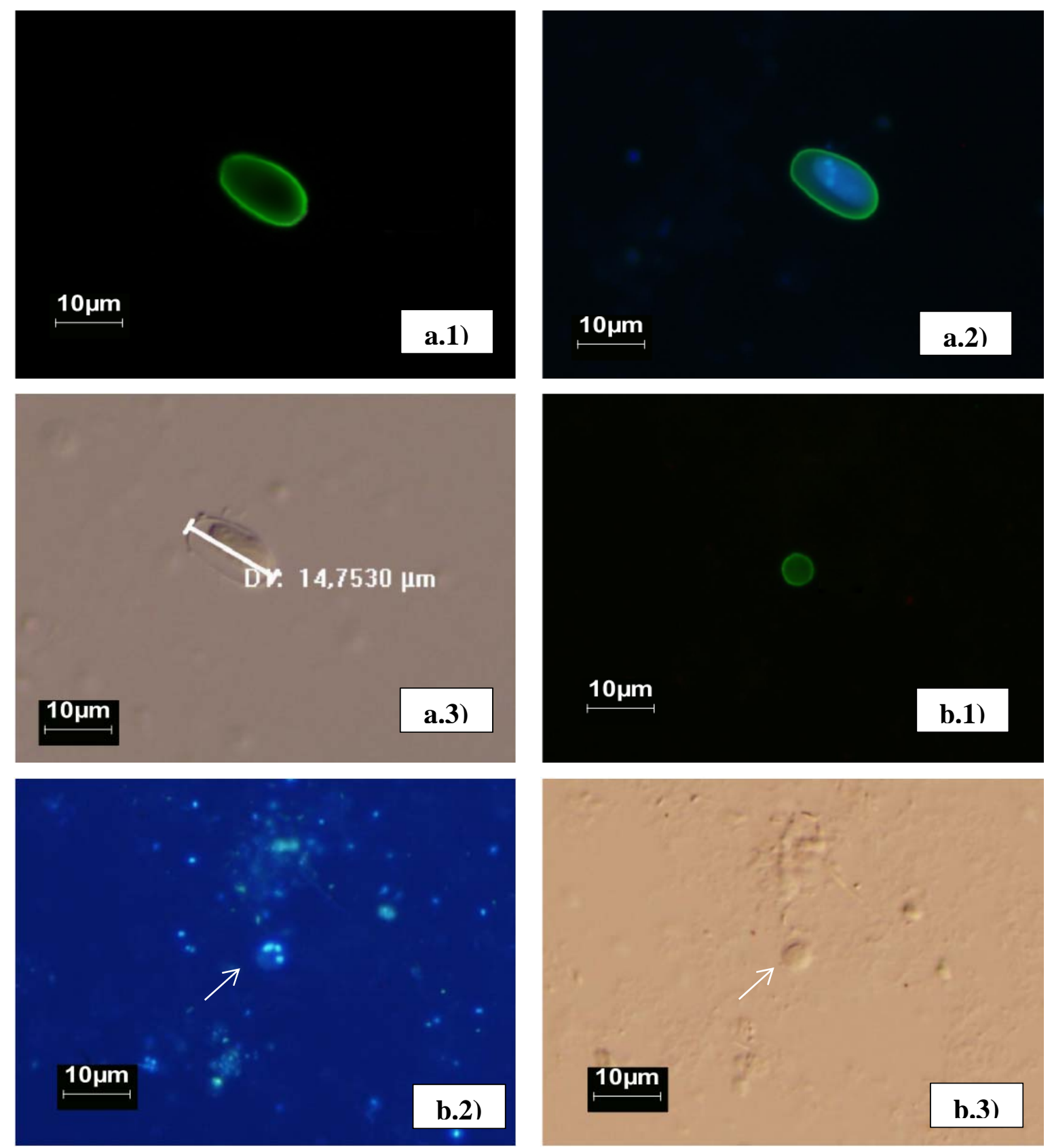

Figura 5.12- Imagens de microscopia do teste de controle de qualidade com separação imunomagnética, com aumento de 400x; a.1) cisto de Giardia spp. em microscopia de fluorescência e filtro de FITC; a.2) cisto de Giardia spp. em microscopia de fluorescência e filtro de DAPI; a.3) cisto de Giardia spp. em microscopia DIC; b.1) oocisto de Cryptosporidium spp. em microscopia de fluorescência e filtro de FITC; b.2) cisto de Cryptosporidium spp. em microscopia de fluorescência e filtro de DAPI; b.3) cisto de Cryptosporidium spp. em microscopia DIC. 
Tabela 5.12- Recuperação de (oo)cistos para água de estudo (matriz com turbidez elevada 120 uT), método de concentração de protozoários por filtração em membranas em testes com e sem o uso de separação imunomagnética

\begin{tabular}{|c|c|c|c|c|}
\hline \multirow{2}{*}{ 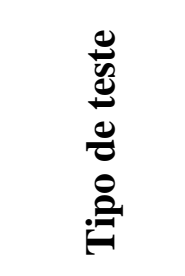 } & \multicolumn{2}{|c|}{$\begin{array}{c}\text { Porcentagem média de recuperação } \\
\text { número de ensaios (n) }=4\end{array}$} & \multicolumn{2}{|c|}{$\begin{array}{l}\text { Coeficiente de Variação } \\
\text { número de ensaios }(n)=4\end{array}$} \\
\hline & Giardia spp. & $\begin{array}{c}\text { Cryptosporidium } \\
\text { spp. }\end{array}$ & Giardia spp. & $\begin{array}{c}\text { Cryptosporidium } \\
\text { spp. }\end{array}$ \\
\hline Sem IMS & $80,0 \%$ & $5,0 \%$ & $20,4 \%$ & $200,0 \%$ \\
\hline Com IMS & $31,5 \%$ & $5,7 \%$ & $24,0 \%$ & $55,7 \%$ \\
\hline
\end{tabular}

Em suma, a porcentagem de recuperação foi abaixo do critério de aceitação do Método 1623.1 para oocistos de Cryptosporidium spp. Pode ter havido perdas significativas deste protozoário nas etapas de raspagem da membrana e concentração por centrifugação. $\mathrm{O}$ referido método estabelece a rotação de mínima de 1500 × $\mathrm{g}$, por 15 minutos, que foi a utilizada neste estudo, talvez uma rotação maior pudesse resultar em melhores eficiências de recuperação.

Clancy et. al. (2000) estudaram a porcentagem de recuperação de oocistos com diferentes forças e tempos de centrifugação $(650$ x G, 1050 x G e 2170 x G; 5, 10 e 15 minutos), além de compararem estas condições em diferentes soluções de eluição (água, tampão Laureth-12 0,01\% e Tween 20 0,01\%). Nesta pesquisa, o melhor desempenho na recuperação de oocistos ocorreu nos ensaios nos quais foram empregados maior força gravitacional e maior tempo de centrifugação. A exceção ocorreu quando o Tween 20 0,01\% foi utilizado como solução de eluição; neste caso, a maior porcentagem de recuperação ocorreu, também, à rotação de 2170 x G, porém, o tempo foi de 10 minutos.

O Método 1623.1 explicíta que maiores recuperações de (oo)cistos podem ser atingidas em rotações de 1800 a 2000 x g. No entanto, ressalta-se que forças tão altas não devam ser utilizadas no caso de a amostra conter areia ou outro material arenoso que possa ocasionar degradação as condições dos (oo)cistos.

Outra hipótese para a baixa identificação de oocistos de Cryptosporidium é a dificuldade de visualização destes microrganismos na microscopia, como já apontado anteriormente. Esta hipótese é mais remota para os casos em que se realiza a etapa de IMS, 
nessa situação, a coloração fluorescente, embora algumas vezes enfraquecida, tem como contraste o fundo preto. Nesta pesquisa, o anticorpo de detecção utilizado foi o do kit Merifluor ${ }^{\circledR}$. Clancy et al. (2000) avaliaram sete marcas comerciais de anticorpos de detecção, no critério contagem de oocistos e intensidade de fluorescência. Os anticorpos do kit Merifluor ${ }^{\circledR}$ apresentaram a segunda maior contagem, ficando atrás do $\operatorname{ImmuCell} \AA$, no entanto, dentre os avaliados, apresentaram a menor intensidade de fluorescência.

\subsubsection{ENSAIOS INTERMEDIÁRIOS DO CONTROLE DE QUALIDADE DO MÉTODO DE IDENTIFICAÇÃO DE PROTOZOÁRIOS}

O Método USEPA 1623.1 indica que devam ser realizados ensaios de controle da qualidade da metodologia de identificação de protozoários a cada vinte testes aplicados. O objetivo destes testes é atestar a confiabilidade dos resultados obtidos no laboratório de pesquisa. Em função da viabilidade econômica na realização de ensaios de qualidade, optouse por fazer um teste de qualidade quando fosse atingida a metade dos experimentos propostos para o trabalho. Os resultados dos ensaios intermediários são apresentados na Tabela 5.13.

Para estes testes, realizaram-se simultaneamente os experimentos sem IMS e com IMS, conforme descrito na seção 4.4.1.2.

Tabela 5.13- Recuperação de (oo)cistos para água de estudo (matriz com turbidez elevada $\sim 120 \mathrm{uT}$ ), realizados na metade dos experimentos, método de concentração de protozoários por filtração em membranas em testes com e sem o uso de separação imunomagnética

\begin{tabular}{cccccc}
\hline \multirow{2}{*}{ Teste No } & \multirow{2}{*}{$\begin{array}{c}\text { Tipo de } \\
\text { teste }\end{array}$} & $\begin{array}{c}\text { Giardia } \\
\text { spp. }\end{array}$ & $\begin{array}{c}\text { Enumeração } \\
\text { Cryptosporidum } \\
\text { spp. }\end{array}$ & $\begin{array}{c}\text { Porcentagem de recuperação } \\
\text { Giardia }\end{array}$ & $\begin{array}{c}\text { Cryptosporidum } \\
\text { spp. }\end{array}$ \\
\hline 24 & & 4 & 1 & $80 \%$ & spp. \\
25 & \multirow{2}{*}{ Sem IMS } & 2 & 0 & $40 \%$ & $20 \%$ \\
26 & 2 & 2 & $40 \%$ & $0 \%$ \\
27 & 4 & 0 & $80 \%$ & $40 \%$ \\
\hline Média & & & & $60 \%$ & $0 \%$ \\
\hline CV & & & & $38 \%$ & $78 \%$ \\
\hline
\end{tabular}


Tabela 5.14 (cont.)- Recuperação de (oo)cistos para água de estudo (matriz com turbidez elevada $120 \mathrm{uT}$ ), realizados na metade dos experimentos, método de concentração de protozoários por filtração em membranas em testes com e sem o uso de separação imunomagnética

\begin{tabular}{|c|c|c|c|c|c|}
\hline \multirow{2}{*}{ Teste $\mathbf{N}^{\mathbf{o}}$} & \multirow{2}{*}{$\begin{array}{l}\text { Tipo de } \\
\text { ensaio }\end{array}$} & \multicolumn{2}{|c|}{ Enumeração } & \multicolumn{2}{|c|}{ Porcentagem de recuperação } \\
\hline & & $\begin{array}{c}\text { Giardia } \\
\text { spp. }\end{array}$ & $\begin{array}{c}\text { Cryptosporidum } \\
\text { spp. }\end{array}$ & $\begin{array}{c}\text { Giardia } \\
\text { spp. }\end{array}$ & $\begin{array}{c}\text { Cryptosporidum } \\
\text { spp. }\end{array}$ \\
\hline 24 & \multirow{4}{*}{ Com IMS } & 10 & 6 & $10 \%$ & $6 \%$ \\
\hline 25 & & 23 & 12 & $23 \%$ & $12 \%$ \\
\hline 26 & & 34 & 12 & $34 \%$ & $12 \%$ \\
\hline 27 & & 20 & 8 & $20 \%$ & $8 \%$ \\
\hline \multicolumn{3}{|l|}{ Média } & & $22 \%$ & $10 \%$ \\
\hline \multicolumn{6}{|l|}{ Coeficiente } \\
\hline de & & & & $45 \%$ & $32 \%$ \\
\hline variação & & & & & \\
\hline
\end{tabular}

\subsection{ENSAIOS DE TRATABILIDADE DA ÁGUA DE ESTUDO COM INÓCULOS DE PROTOZOÁRIOS}

A partir dos parâmetros ótimos encontrados na etapa de ensaios de tratabilidade, realizou-se os ensaios com inóculo de protozoários com o objetivo de se atestar o desempenho das duas condições propostas para a remoção de cistos de Giardia spp. e oocistos de $C$. parvum Avaliou-se a concentração (oo)cistos destes protozoários em 4 fases: água bruta, água decantada, água filtrada e lodo.

O primeiro teste foi realizado para a condição de menor dosagem de coagulante e sem adição de alcalinizante. Foi inoculado um número esperado de Giardia spp. e C. parvum advindos de suspensões purificadas com número estimado de cada um destes organismos.

Embora o número de organismos inoculados em cada ensaio tenha sido estimado para que se chegasse à concentração de 500 cistos de Giardia spp. e 500 oocistos de C. parvum, optou-se por aplicar a metodologia de identificação de protozoários também na água bruta. Esta medida foi tomada por duas razões: i) avaliar o desempenho da metodologia de Franco et al.(2001) para a água com turbidez elevada; e ii) a distribuição dos organismos nas suspensões purificadas dificilmente seria homogênea ao ponto de se obter o mesmo número de organismos em todos ensaios a serem realizados. 
O procedimento de identificação de protozoários para este primeiro ensaio foi realizado para as amostras água bruta, água decantada, água filtrada e lodo sem que houvesse a separação imunomagnética. Os resultados encontram-se na Tabela 5.15.

Tabela 5.15- Número de oocistos e cistos detectados nas diferentes etapas do tratamento proposto, mediante o uso da técnica de filtração em membranas, sem a purificação por separação imunomagnética, após inoculação de número conhecido de protozoários

\begin{tabular}{cccccc}
\hline \multirow{2}{*}{$\begin{array}{c}\text { Número do } \\
\text { teste }\end{array}$} & $\begin{array}{c}\text { Tipo de } \\
\text { amostra }\end{array}$ & $\begin{array}{c}\text { Número de (oo)cistos por } \\
\text { litro de amostra } \\
\text { (oo)cistos. } \mathbf{L}^{-1}\end{array}$ & \multicolumn{2}{c}{$\begin{array}{c}\text { Número de (oo)cistos na } \\
\text { amostra }\end{array}$} \\
\cline { 3 - 6 } & & Giardia spp. & C. parvum & Giardia spp. & C. parvum \\
\hline \multirow{2}{*}{1} & Água bruta & 1426 & 35 & 18824 & 459 \\
\cline { 2 - 6 } & Água & 52 & 3 & 300 & 38 \\
\cline { 2 - 6 } & Ácantada & 0 & 0 & 18619 & 278 \\
\cline { 2 - 6 } & Ĺgua filtrada & 1411 & 21 & 0 \\
\hline
\end{tabular}

Com estes resultados, foi possível realizar um estimativa da presença de (oo)cistos de protozoários em cada fase do tratament. Devido à variação da porcentagem de recuperação inerente à metodologia de identificação de Giardia spp. e C. parvum, a distribuição da presença dos protozoários em cada etapa não corresponde a real, pois a soma dos organismos quantificados nas águas decantada, filtrada e lodo deveria ser igual aos organismos quantificados na água bruta.

Este primeiro teste permitiu avaliar as condições de identificação dos (oo)cistos de protozoários quando não é realizado o procedimento de separação imunomagnética. A qualidade dos poços contendo as alíquotas concentradas de água decantada e do lodo impuseram certas dificuldades na leitura dos organismos, pois apresentavam uma camada espessa na cor vermelha na microscopia de fluorescência (Figura 5.13), possivelmente pela interação do coagulante com a caulinita. 
Com base nas observações do primeiro teste, decidiu-se que não seria realizado o procedimento de identificação de protozoários sem a separação imunomagnética para a água decantada e para o lodo.

Outra observação importante foi a não identificação de cistos de Giardia spp. e oocistos de C. parvum na água filtrada. O número mínimo detectável para este tipo de amostra é alto. A ausência de identificação é um indicativo da necessidade dos testes com separação imunomagnética (IMS) para água filtrada.

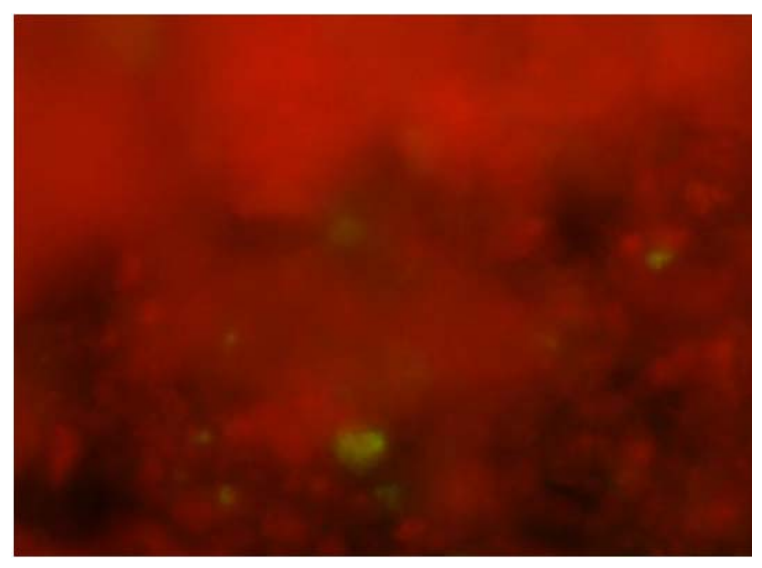

Figura 5.13- Aspecto de um poço de lâmina de microscopia de imunofluorescência contendo alíquota de amostra de lodo, sem purificação por IMS, visualização em microscopia de fluorescência em comprimento de onda excitação $\lambda=450$ a $490 \mathrm{~nm}$ e barreira $\lambda=520 \mathrm{~nm}$ (aumento de 400x)

\subsubsection{ENSAIOS DE TRATABILIDADE DA ÁGUA DE ESTUdo SEM O EMPREgo DA METODOLOGIA DE SEPARAÇÃO IMUNOMAGNÉTICA PARA A IDENTIFICAÇÃO DE PROTOZOÁRIOS}

A realização de ensaios de identificação de protozoários sem a etapa de purificação por separação imunomagnética apresentou, de forma geral, eficiências de recuperação muito elevadas de cistos de Giardia spp. para água com grande número de protozoários (água de estudo antes das etapas de tratabilidade). Para o caso de águas com baixo número esperado de cistos de Giardia spp. e oocistos de C. parvum, com esta metodologia não foi possível identificar microrganismo na quase totalidade dos ensaios, pois o número mínimo identificável por volume do método é alto. Algumas imagens típicas de microscopia da realização deste procedimento são mostradas em APÊNDICE. 


\subsubsection{ESTUdO DA IDENTIFICAÇÃO E REMOÇÃO DE CISTOS DE GIARDIA SPP. SEM EMPREGO DE IMS}

A Tabela 5.16 apresenta os resultados da identificação de cistos de Giardia spp. nos ensaios de tratabilidade para a primeira condição de coagulação estudada (dose de $25 \mathrm{mg} . \mathrm{L}^{-1}$ de PAC e ausência de correção de $\mathrm{pH}$ ). A eficiência média de recuperação de cistos de Giardia spp. na água bruta foi de 102,75\% e o coeficiente de variação de 30,28\%. A remoção média de cistos de Giardia spp. do tratamento foi de $2,26 \pm 0,14 \log _{10}$.

Tabela 5.16- Número de cistos de Giardia spp. detectados nos ensaios de tratabilidade para a primeira condição de coagulação (dose de 25 mg. $\mathrm{L}^{-1}$ de PAC e ausência de correção de $\mathbf{p H})$ quando a purificação por IMS não foi empregada e remoção $\left(e m \log _{10}\right)$

\begin{tabular}{|c|c|c|c|c|c|c|}
\hline \multirow[t]{2}{*}{ Teste } & \multirow{2}{*}{$\begin{array}{l}\text { Tipo de } \\
\text { amostra }\end{array}$} & \multirow{2}{*}{$\begin{array}{l}\mathrm{N}^{0} \text { cistos } \\
\text { amostra } \\
\text { composta } \\
\left({ }^{*}\right),\left({ }^{* *}\right)\end{array}$} & \multicolumn{2}{|c|}{$\begin{array}{c}\mathrm{N}^{0} \text { de cistos de Giardia } \\
\text { spp. por litro (cistos. } \mathrm{L}^{-1} \text { ) }\end{array}$} & \multirow{2}{*}{$\begin{array}{c}\text { Porcentagem } \\
\text { de } \\
\text { recuperação }\end{array}$} & \multirow{2}{*}{$\begin{array}{l}\text { Remoção } \\
\left(\text { em } \log _{10}\right)\end{array}$} \\
\hline & & & Enumerado & Esperad. & & \\
\hline \multirow{2}{*}{1.1} & água bruta & 8339 & 695 & 500 & $139 \%$ & - \\
\hline & água filtrada & 0 & 0 & - & - & $>2,41$ \\
\hline \multirow{2}{*}{1.2} & água bruta & 6387 & 532 & 500 & $106 \%$ & - \\
\hline & água filtrada & 0 & 0 & - & - & $>2,29$ \\
\hline \multirow{2}{*}{1.3} & água bruta & 6200 & 516 & 500 & $103 \%$ & - \\
\hline & água filtrada & 0 & 0 & - & - & $>2,28$ \\
\hline \multirow{2}{*}{1.4} & água bruta & 3800 & 317 & 500 & $63 \%$ & - \\
\hline & água filtrada & 0 & 0 & - & - & $>2,07$ \\
\hline média & & & & & $102,75 \%$ & 2,26 \\
\hline d.p. & & & & & $31,12 \%$ & 0,14 \\
\hline
\end{tabular}

Observações: O símbolo ">” (maior que) indica que não houve detecção de organismo pelo método e o cálculo da remoção considerou o número mínimo identificável por volume ( $\log _{10}$ conc.água bruta - $\log _{10}$ "número mínimo detectável”);*valor correspondente ao número de (oo)cistos nos 12 L de todos os jarros do jarteste, para água bruta.;**valor calculado conforme Equação 4 
O teste de número 1.4 apresentou uma porcentagem de recuperação de Giardia spp. inferior às demais. $\mathrm{O}$ ocorrido pode ser explicado pelo fato de que este teste foi realizado com cepas de Giardia spp. mais antigas. Neste caso, antes da inoculação no jarro, realizou-se o procedimento de rompimento de agregados de (oo)cistos, descrito em 4.4.2. Ainda assim, a recuperação foi aquém dos outros testes.

A Tabela 5.17 apresenta os resultados da identificação de cistos de Giardia spp. para a segunda condição de coagulação estudada (dose de 65 mg. $\mathrm{L}^{-1}$ de PAC e 15 mg. $\mathrm{L}^{-1}$ de $\mathrm{NaOH}$ como alcalinizante). A eficiência média de recuperação de cistos de Giardia spp. foi de $123,33 \%$ e o coeficiente de variação de $65,54 \%$. A remoção média de cistos de Giardia spp. foi de $2,31 \pm 0,26 \log _{10}$.

Tabela 5.17- Número de cistos de Giardia spp. detectados nos ensaios de tratabilidade para a segunda condição de coagulação (dose de 65 mg. $\mathrm{L}^{-1}$ de PAC e 15 mg. $L^{-1}$ de $\mathrm{NaOH}$ ) quando a purificação por IMS não foi empregada e remoção (em $\left.\log _{10}\right)$

\begin{tabular}{|c|c|c|c|c|c|c|}
\hline \multirow[t]{2}{*}{ Teste } & \multirow[t]{2}{*}{$\begin{array}{l}\text { Tipo de } \\
\text { amostra }\end{array}$} & \multirow{2}{*}{$\begin{array}{l}\mathrm{N}^{0} \text { cistos } \\
\text { amostra } \\
\text { composta } \\
\left({ }^{*}\right),(* *)\end{array}$} & \multicolumn{2}{|c|}{ 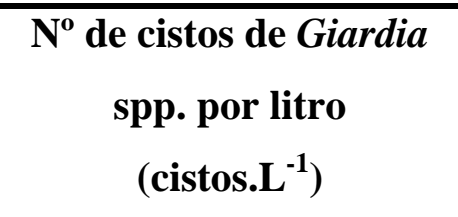 } & \multirow[t]{2}{*}{$\begin{array}{l}\text { Porcentagem } \\
\text { de } \\
\text { Recuperação }\end{array}$} & \multirow[t]{2}{*}{$\begin{array}{c}\text { Remoção } \\
(\text { em } \\
\left.\log _{10}\right)\end{array}$} \\
\hline & & & Enumerado & Esperad. & & \\
\hline \multirow{2}{*}{2.1} & água bruta & 4000 & 333 & 500 & $67 \%$ & $>2,10$ \\
\hline & água filtrada & 0 & 0 & - & - & - \\
\hline \multirow{2}{*}{2.2} & água bruta & 5400 & 450 & 500 & $90 \%$ & 2,23 \\
\hline & água filtrada & $13^{* * *}$ & 3 & - & - & - \\
\hline \multirow{2}{*}{2.3} & água bruta & 12800 & 1067 & 500 & $213 \%$ & $>2,60$ \\
\hline & água filtrada & 0 & 0 & - & - & - \\
\hline \multirow{2}{*}{$\begin{array}{c}\text { média } \\
\text { d.p. }\end{array}$} & & & & & $123,33 \%$ & 2,31 \\
\hline & & & & & $78,50 \%$ & 0,26 \\
\hline
\end{tabular}

Observações: O símbolo ">” (maior que) indica que não houve detecção de organismo pelo método e 0 cálculo da remoção considerou o número mínimo detectável $\left(\log _{10}\right.$ conc.água bruta $-\log _{10}$ "número mínimo detectável") .*valor correspondente ao número de (oo)cistos nos $12 \mathrm{~L}$ de todos os jarros do jarteste, para água bruta; **valor calculado conforme Equação $4 ;{ }^{* * *}$ Foi visualizado 1 cisto na etapa de microscopia na amostra de água filtrada, no entanto, o número mínimo detectável do método era alto (13) o que tenha talvez superestimado o número de cistos nesta amostra. 
Os resultados dos dois ensaios mostraram que não houve aumento da remoção de Giardia spp. com o incremento da dosagem de coagulante quando o método de identificação não utilizou a etapa de purificação por IMS. As diferenças nas médias de remoção são devidas às variações nos valores de concentração de cistos lidos na água bruta

\subsubsection{ESTUdO DA IDENTIFICAÇÃO E REMOÇÃO DE OOCISTOS DE CRYPTOSPORIDIUM SEM EMPREGO DE IMS}

A identificação de oocistos de C. parvum mostrou-se deficiente nos testes 1.1, 1.2 e 2.1, antes do emprego da metodologia de rompimento de agregados de (oo)cistos de protozoários, descrita no item 4.4.2. Os resultados da identificação de oocistos de C. parvum sem a etapa de separação imunomagnética são apresentados na Tabela 5.18, para a primeira condição de coagulação (dose de $25 \mathrm{mg} . \mathrm{L}^{-1}$ de PAC e ausência de correção de $\mathrm{pH}$ ). A eficiência média de recuperação de oocistos de C. parvum na água bruta foi de $13,10 \%$ e o coeficiente de variação de $54,23 \%$. A eficiência média de remoção do tratamento foi de $1,30 \pm 0,35 \log _{10}$.

Os resultados para a segunda condição de coagulação (dosagem de 65 mg.L-1 de PAC e 15 mg.L-1 de $\mathrm{NaOH}$ ) são apresentados na Tabela 5.19. A eficiência média de recuperação de oocistos de C. parvum na água bruta foi de $33,33 \%$ e o coeficiente de variação de $62,45 \%$. A eficiência média de remoção do tratamento foi de $1,71 \pm 0,37 \log _{10}$.

De forma semelhante à remoção de cistos de Giardia spp. não houve considerável melhora no desempenho do tratamento quanto à remoção de oocistos de C. parvum com o aumento da dosagem de coagulante PAC de $25 \mathrm{mg} . \mathrm{L}^{-1}$ para $65 \mathrm{mg} . \mathrm{L}^{-1}$. 
Tabela 5.18- Número de oocistos de $C$. parvum detectados nos ensaios de tratabilidade para a primeira condição de coagulação (dose de $25 \mathrm{mg}^{-L^{-1}}$ de PAC e ausência de correção de $\mathbf{p H}$ ) quando a purificação por IMS não foi empregada e remoção $\left(e m \log _{10}\right)$

\begin{tabular}{|c|c|c|c|c|c|c|}
\hline \multirow{2}{*}{$\begin{array}{c}\mathbf{N}^{\mathbf{o}} \\
\text { Teste }\end{array}$} & \multirow{2}{*}{$\begin{array}{l}\text { Tipo de } \\
\text { amostra }\end{array}$} & \multirow{2}{*}{$\begin{array}{l}\mathrm{N}^{0} \text { oocistos } \\
\text { amostra } \\
\text { composta } \\
\qquad\left(^{*}\right),\left({ }^{* *}\right)\end{array}$} & \multicolumn{2}{|c|}{$\begin{array}{c}\mathrm{N}^{0} \text { de oocistos de } C \text {. } \\
\text { parvum por litro } \\
\left(\text { cistos. } \mathrm{L}^{-1}\right)\end{array}$} & \multirow{2}{*}{$\begin{array}{c}\text { Porcentagem } \\
\text { de } \\
\text { Recuperação }\end{array}$} & \multirow{2}{*}{$\begin{array}{c}\text { Remoção } \\
(\text { em } \\
\left.\log _{10}\right)\end{array}$} \\
\hline & & & Enumerado & Esperado & & \\
\hline \multirow{2}{*}{1.1} & água bruta & 204 & 17 & 500 & $3,40 \%$ & - \\
\hline & $\begin{array}{l}\text { água } \\
\text { filtrada }\end{array}$ & 0 & 0 & - & - & $>0,80$ \\
\hline \multirow{3}{*}{1.2} & água bruta & 968 & 81 & 500 & $16,20 \%$ & - \\
\hline & $\begin{array}{l}\text { água } \\
\text { filtrada }\end{array}$ & 0 & 0 & - & - & $>1,48$ \\
\hline & água bruta & 768 & 64 & 500 & $12,80 \%$ & - \\
\hline 1.3 & $\begin{array}{l}\text { água } \\
\text { filtrada }\end{array}$ & 0 & 0 & - & - & 1,37 \\
\hline \multirow{2}{*}{1.4} & água bruta & 1200 & 100 & 500 & $20,00 \%$ & - \\
\hline & $\begin{array}{l}\text { água } \\
\text { filtrada }\end{array}$ & 0 & 0 & - & - & $>1,57$ \\
\hline média & & & & & $13,10 \%$ & 1,30 \\
\hline d.p. & & & & & $7,10 \%$ & 0,35 \\
\hline
\end{tabular}

Observações: O símbolo ">” (maior que) indica que não houve deteç̧ão de organismo pelo método e o cálculo da remoção considerou o número mínimo detectável ( $\log _{10}$ conc.água bruta - $\log _{10}$ "número mínimo detectável") ;*valor correspondente ao número de (oo)cistos nos 12 Lde todos os jarros do jarteste, para água bruta.;**valor calculado conforme Equação 4 
Tabela 5.19- Número de oocistos de $C$. parvum detectados nos ensaios de tratabilidade para a segunda condição de coagulação (dose de 65 mg.L ${ }^{-1}$ de PAC e 15 mg.L $L^{-1}$ de $\left.\mathrm{NaOH}\right)$ quando a purificação por IMS não foi empregada e remoção $\left(\log _{10}\right)$

\begin{tabular}{|c|c|c|c|c|c|c|}
\hline \multirow[t]{2}{*}{ Teste } & \multirow{2}{*}{$\begin{array}{l}\text { Tipo de } \\
\text { amostra }\end{array}$} & \multirow{2}{*}{$\begin{array}{c}\mathrm{N}^{\circ} \text { Oocistos } \\
\text { amostra } \\
\text { composta } \\
\left(^{*}\right) \text { e }\left(^{* *}\right)\end{array}$} & \multicolumn{2}{|c|}{$\begin{array}{c}\mathrm{N}^{\mathrm{o}} \text { de oocistos de } C \text {. } \\
\text { parvum por litro } \\
\left(\text { cistos. } \mathrm{L}^{-1}\right)\end{array}$} & \multirow{2}{*}{$\begin{array}{c}\text { Porcentagem } \\
\text { de } \\
\text { Recuperação }\end{array}$} & \multirow{2}{*}{$\begin{array}{c}\text { Remoção } \\
(\text { em } \\
\left.\log _{10}\right)\end{array}$} \\
\hline & & & Enumerado & Esper. & & \\
\hline \multirow{2}{*}{2.1} & água bruta & 600 & 50 & 500 & $10 \%$ & - \\
\hline & $\begin{array}{c}\text { água } \\
\text { filtrada }\end{array}$ & 0 & 0 & - & - & $>1,28$ \\
\hline \multirow{2}{*}{2.2} & água bruta & 2400 & 200 & 500 & $40 \%$ & - \\
\hline & $\begin{array}{c}\text { água } \\
\text { filtrada }\end{array}$ & $13 * * *$ & 3 & - & - & 1,88 \\
\hline \multirow{2}{*}{2.3} & água bruta & 3000 & 250 & 500 & $50 \%$ & - \\
\hline & $\begin{array}{c}\text { água } \\
\text { filtrada }\end{array}$ & 0 & 0 & - & - & $>1,97$ \\
\hline média & & & & & $33,33 \%$ & 1,71 \\
\hline d.p. & & & & & $20,82 \%$ & 0,37 \\
\hline
\end{tabular}

Observações: O símbolo ">” (maior que) indica que não houve detecção de organismo pelo método e o cálculo da remoção considerou o número mínimo detectável $\left(\log _{10}\right.$ conc.água bruta - $\log _{10}$ "número mínimo detectável”) ;*valor correspondente ao número de (oo)cistos nos 12 Lde todos os jarros do jarteste, para água bruta.;*valor calculado conforme Equação $4 * * *$; *** Foi visualizado 1 cisto na etapa de microscopia na amostra de água filtrada, no entanto, o número mínimo detectável do método era alto (13) o que tenha talvez superestimado o número de cistos nesta amostra.

\subsubsection{Ensaios de tratabilidade DA ÁguA DE ESTUdo COM O EMPREgo DA METODOLOGIA DE SEPARAÇÃO IMUNOMAGNÉTICA PARA A IDENTIFICAÇÃO DE (OO)CISTOS DE PROTOZOÁRIOS}

Para o estudo da tratabilidade de protozoários com o uso da etapa de purificação por IMS, foi possível estimar a concentração de (oo)cistos em diferentes fases do tratamento. Considerou-se a análise da água bruta, água decantada, água filtrada e lodo. 
Em teoria, quando se considera a soma dos organismos detectados em cada etapa do tratamento, a mesma deveria ser similar à quantidade destes organismos na entrada do sistema, isso é, na água bruta. Os itens subsequentes apresentam os resultados da identificação de cistos de Giardia spp. e oocistos de C. parvum, respectivamente. Imagens de microscopia típicas destes ensaios são mostradas em APÊNDICE.

\subsubsection{ESTUdo DA IDENTIFICAÇÃO E REMOÇÃO DE CISTOS DE GIARDIA SPP. COM EMPREGO DE IMS}

Os resultados da identificação de cistos de Giardia spp. na primeira condição de coagulação (dosagem de PAC de 25 mg.L-1 e ausência de correção de pH) são apresentados na Tabela 5.20. A porcentagem média de recuperação de cistos de Giardia spp. na água bruta foi de $67 \%$ e o coeficiente de variação de $72 \%$. A eficiência média de remoção para a

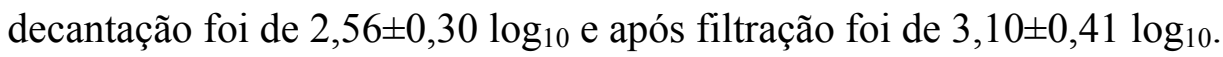

Observa-se que nos testes 1.3 IMS e 1.4 IMS ( Tabela 5.20) não houve identificação de cistos de Giardia spp. na amostra de água decantada. Este fato é um indicativo de que esta água (que passou por um longo período de decantação) possui qualidade superior à água afluente aos FLA. Esta água, portanto, não pode ser considerada rigorosamente como água decantada.

O método de identificação utilizado para amostras de lodo foi o de concentração por filtração em membranas de ésteres mistos de celulose, de forma semelhante às demais amostras. Padronizou-se a utilização de apenas 3 membranas por amostra lodo, isto foi feito como forma de dinamizar a rotina extensa de análise laboratorial. A raspagem e eluição do material retido nas membranas que filtravam as amostras de lodo demoravam cerca de uma hora, para 3 membranas, acrescido ainda do tempo da própria filtração por bomba à vácuo.

A estimativa do número de cistos de Giardia spp. em cada etapa do tratamento não pôde ser realizada da maneira adequada porque a recuperação destes nas amostras de lodo foi baixa. Para o estudo da amostra de lodo foram consideradas alíquotas para a realização da concentração e purificação de protozoários. A primeira alíquota corresponde ao ato de filtrar a amostra em apenas 3 membranas, referente a um quarto do volume da amostra em questão. A segunda alíquota acontecia na etapa de IMS, já que o pellet final possuía um volume superior a $500 \mu \mathrm{L}$, como foi descrito em 4.4.1.3. 
Tabela 5.20- Número de cistos de Giardia spp. detectados nos ensaios de tratabilidade para a primeira condição de coagulação, em diferentes etapas, (dose de 25 mg.L $L^{-1}$ de PAC e ausência de correção de $\mathrm{pH}$ ) com emprego de IMS e remoção (em $\left.\log _{10}\right)$

\begin{tabular}{|c|c|c|c|c|c|c|}
\hline \multirow[t]{2}{*}{ Teste } & \multirow[t]{2}{*}{ Tipo de amostra } & \multirow{2}{*}{$\begin{array}{c}\text { Número } \\
\text { de cistos } \\
\text { na amostra } \\
\text { composta } \\
(*),(* *)\end{array}$} & \multicolumn{2}{|c|}{$\begin{array}{c}\text { Número } \\
\text { de cistos de } \\
\text { Giardia spp. por litro } \\
\left(\text { cistos. } L^{-1}\right)\end{array}$} & \multirow[t]{2}{*}{$\begin{array}{c}\text { Porcentagem } \\
\text { de } \\
\text { recuperação }\end{array}$} & \multirow[t]{2}{*}{$\begin{array}{l}\text { Remoção } \\
\left(\text { em log } \log _{10}\right)\end{array}$} \\
\hline & & & Enumerado & Esperado & & \\
\hline \multirow{4}{*}{$\begin{array}{c}1.1 \\
\text { IMS }\end{array}$} & água bruta & 6915 & 576 & 500 & $115 \%$ & \\
\hline & água decantada & 11 & 2 & - & & 2,48 \\
\hline & água filtrada & 1 & $<1$ & - & & 3,46 \\
\hline & lodo & 1423 & 619 & - & & \\
\hline \multirow{4}{*}{$\begin{array}{c}1.2 \\
\text { IMS }\end{array}$} & água bruta & 6387 & 512 & 500 & $102 \%$ & \\
\hline & água decantada & 18 & 3 & - & & 2,22 \\
\hline & água filtrada & 1 & $<1$ & - & & 3,41 \\
\hline & lodo & 1518 & 809 & - & & \\
\hline \multirow{4}{*}{$\begin{array}{c}1.3 \\
\text { IMS }\end{array}$} & água bruta & 2163 & 180 & 500 & $36 \%$ & \\
\hline & água decantada & 0 & 0 & - & & $>2,95$ \\
\hline & água filtrada & 0 & 0 & - & & $>2,95$ \\
\hline & lodo & 425 & 202 & - & & \\
\hline \multirow{4}{*}{$\begin{array}{c}1.4 \\
\text { IMS }\end{array}$} & água bruta & 3800 & 79 & 500 & $16 \%$ & \\
\hline & água decantada & 0 & 0 & - & & $>2,60$ \\
\hline & água filtrada & 0 & 0 & - & & $>2,60$ \\
\hline & lodo & 248 & 126 & - & & \\
\hline
\end{tabular}

Observações: O símbolo “>” (maior que) indica que não houve detecção de organismo pelo método e o cálculo da remoção considerou o número mínimo detectável $\left(\log _{10}\right.$ conc.água bruta $-\log _{10}$ "número mínimo detectável") ;*valor correspondente ao número de (oo)cistos nos $12 \mathrm{~L}$ de todos os jarros do jarteste, para água bruta.;**valor calculado conforme Equação 4

Para a segunda condição de coagulação (dosagem de $65 \mathrm{mg} . \mathrm{L}^{-1}$ de PAC e $15 \mathrm{mg} . \mathrm{L}^{-1}$ de $\mathrm{NaOH}$ ) os resultados são apresentados na Tabela 5.21. A porcentagem média de recuperação de cistos de Giardia spp. foi de $57 \%$ e o coeficiente de variação de $44 \%$. A eficiência média do tratamento até a fase de decantação foi de $2,33 \pm 0,74 \log _{10}$ e após a filtração foi de $2,92 \pm 0,09 \log _{10}$. 
Tabela 5.21- Número de cistos de Giardia spp. detectados nos ensaios de tratabilidade para a segunda condição de coagulação, em diferentes etapas, (dose de 65 mg.L ${ }^{-1}$ de PAC e 15 mg.L ${ }^{-1}$ de $\mathrm{NaOH}$ ) com emprego de IMS e remoção (em $\left.\log _{10}\right)$

\begin{tabular}{|c|c|c|c|c|c|c|}
\hline \multirow[t]{2}{*}{ Teste } & \multirow[t]{2}{*}{$\begin{array}{c}\text { Tipo } \\
\text { de } \\
\text { amostra }\end{array}$} & \multirow[t]{2}{*}{$\begin{array}{l}\text { Número } \\
\text { de cistos } \\
\text { na amostra } \\
\text { composta } \\
(*),\left(^{* *}\right)\end{array}$} & \multicolumn{2}{|c|}{$\begin{array}{c}\text { Número } \\
\text { de cistos de } \\
\text { Giardia spp. por litro } \\
\left(\text { cistos. } L^{-1}\right)\end{array}$} & \multirow[t]{2}{*}{$\begin{array}{l}\text { Porcentagem } \\
\text { de } \\
\text { recuperação }\end{array}$} & \multirow[t]{2}{*}{$\begin{array}{c}\text { Remoção } \\
(\text { em } \\
\left.\log _{10}\right)\end{array}$} \\
\hline & & & Enumerado & Esper. & & \\
\hline \multirow{4}{*}{$\begin{array}{c}2.1 \\
\text { IMS }\end{array}$} & $\overline{\text { água bruta }}$ & 1968 & 164 & 500 & $33 \%$ & \\
\hline & água decantada & 26 & 5 & - & & 1,49 \\
\hline & água filtrada & 1 & $<1$ & - & & 2,89 \\
\hline & lodo & 311 & 206 & - & & \\
\hline \multirow{4}{*}{$\begin{array}{c}2.2 \\
\text { IMS }\end{array}$} & água bruta & 4989 & 416 & 500 & $83 \%$ & \\
\hline & água decantada & 16 & 3 & - & & 2,6 \\
\hline & água filtrada & 2 & 0,4 & - & & 3,0 \\
\hline & lodo & 597 & 100 & - & & \\
\hline \multirow{4}{*}{$\begin{array}{c}2.3 \\
\text { IMS }\end{array}$} & água bruta & 3261 & 271,8 & 500 & $54 \%$ & \\
\hline & água decantada & 2 & $<1$ & - & & 2,9 \\
\hline & água filtrada & 2 & $<1$ & - & & 2,9 \\
\hline & lodo & 551 & 100,0 & - & & \\
\hline
\end{tabular}

Observações: O símbolo ">” (maior que) indica que não houve detecção de organismo pelo método e o cálculo da remoção considerou o número mínimo detectável $\left(\log _{10}\right.$ conc.água bruta $-\log _{10}$ "número mínimo detectável") ;*valor correspondente ao número de (oo)cistos nos $12 \mathrm{~L}$ de todos os jarros do jarteste, para água bruta.;**valor calculado conforme Equação 4

Para análise das amostras de lodo, no teste 2.1 (Tabela 5.21) procedeu-se de forma semelhante aos testes de 1.1IMS a 1.4IMS, da Tabela 5.20, no entanto, a turbidez do lodo ressuspenso em água deionizada foi muito elevada para esta condição de coagulação (mais de $1000 \mathrm{uT}$ ). Este fato resultou em dificuldades nas etapas de homogeneização das amostras e baixa qualidade da lâmina final de microscopia. Diante disso, padronizou-se ressuspender todo o lodo do tratamento em 3 jarros do aparelho de jarteste e encaminhar 2 litros de toda amostra para a etapa de concentração e purificação de protozoários. Ou seja, mais uma alíquota foi necessária no processo de identificação de amostras de lodo.

Observa-se que para os testes na segunda condição de coagulação houve um baixo desvio padrão da eficiência de remoção de cistos de Giardia spp. após o filtro. Este baixo valor se deve a uma menor variação na concentração de cistos identificada na água bruta. De 
forma geral, os dois tratamentos estudados apresentaram resultados semelhantes de eficiência de remoção. À primeira vista, a primeira condição de coagulação apresentou um desempenho ligeiramente superior à segunda.

\subsubsection{ESTUdo DA IDENTIFICAÇÃo E REMOÇÃo DE OOCISTOS DE C. PARVUM COM EMPREGO DE IMS}

Os resultados da identificação de oocistos de C. parvum, quando foi empregada a purificação por IMS, apresentam-se na Tabela 5.22, para a primeira condição de coagulação. Nestes testes, a porcentagem média de recuperação de oocistos de C. parvum foi de $10 \%$ e o coeficiente de variação de 94\%. A eficiência média de remoção na fase de decantação foi de $2,23 \pm 0,46 \log _{10}$ e após o filtro foi de $2,13 \pm 0,44 \log _{10}$. Supostamente, houve um melhor desempenho da etapa de decantação quando comparada à filtração; porém, tal resultado aconteceu considerando-se que a água foi submetida a uma longa etapa de decantação, razão pela qual apresentou aparente melhor resultado em relação ao efluente dos FLA.

A observação dos resultados da Tabela 5.22 mostra que a porcentagem de recuperação foi inexpressiva nos testes 1.1IMS e 1.2IMS. Isto aconteceu devido ao fato da pesquisa ter sido realizada com oocistos de C. parvum envelhecidos, sujeitos à formação de agregados. Foi realizado o procedimento de ruptura dos agregados no início dos experimentos. Nos testes 1.3IMS e 1.4IMS, realizou-se este procedimento imediatamente antes da inoculação dos protozoários na água de estudo. Tal ato melhorou de forma significativa a recuperação de oocistos de C. parvum.

Ainda sobre os resultados na primeira condição de coagulação, no teste 1.3IMS (Tabela 5.22) não houve identificação de oocistos de C. parvum em fase diferente da água bruta. A explicação mais aceitável é a possível ocultação destas formas pela densidade da amostra (formação de nuvens que dificultam a visualização em microscopia). 
Tabela 5.22- Número de oocistos de $C$. parvum por litro nos ensaios de tratabilidade para a primeira condição de coagulação (dose de $25 \mathrm{mg}^{-L^{-1}}$ de PAC e ausência de correção de $\mathrm{pH})$ com o emprego de purificação por IMS e remoção $\left(\log _{10}\right)$

\begin{tabular}{|c|c|c|c|c|c|c|}
\hline \multirow[t]{2}{*}{ Teste } & \multirow[t]{2}{*}{$\begin{array}{c}\text { Tipo de } \\
\text { amostra }\end{array}$} & \multirow{2}{*}{$\begin{array}{c}N^{0} \text { oocistos } \\
\text { na amostra } \\
\text { composta } \\
(*),(* *) \\
\end{array}$} & \multicolumn{2}{|c|}{$\begin{array}{l}\mathrm{N}^{0} \text { de oocistos de } \\
\text { C. parvum por litro } \\
\left(\text { cistos. } \mathrm{L}^{-1}\right)\end{array}$} & \multirow[t]{2}{*}{$\begin{array}{l}\text { Porcentagem } \\
\text { de } \\
\text { recuperação }\end{array}$} & \multirow[t]{2}{*}{$\begin{array}{c}\text { Remoção } \\
(\text { em } \\
\left.\log _{10}\right)\end{array}$} \\
\hline & & & Enumerado & Esper. & & \\
\hline \multirow{4}{*}{$\begin{array}{c}1.1 \\
\text { IMS }\end{array}$} & água bruta & 139 & 12 & 500 & $2 \%$ & \\
\hline & água decantada & 0 & 0 & - & & $>1,76$ \\
\hline & água filtrada & 0 & 0 & - & & $>1,76$ \\
\hline & lodo & 35 & 15 & - & & \\
\hline \multirow{4}{*}{$\begin{array}{c}1.2 \\
\text { IMS }\end{array}$} & água bruta & 173 & 14 & 500 & $3 \%$ & \\
\hline & água decantada & 1 & $<1$ & - & & 1,93 \\
\hline & água filtrada & 0 & 0 & - & & $>1,86$ \\
\hline & lodo & 124 & 66 & - & & \\
\hline \multirow{4}{*}{$\begin{array}{c}1.3 \\
\text { IMS }\end{array}$} & água bruta & 1333 & 111 & 500 & $22 \%$ & \\
\hline & água decantada & 0 & 0 & - & & $>2,74$ \\
\hline & água filtrada & 0 & 0 & - & & $>2,74$ \\
\hline & lodo & 0 & 0 & - & & \\
\hline \multirow{4}{*}{$\begin{array}{c}1.4 \\
\text { IMS }\end{array}$} & água bruta & 740 & 62 & 500 & $12 \%$ & \\
\hline & água decantada & 0 & 0 & - & & $>2,49$ \\
\hline & água filtrada & 2 & 0 & - & & 2,17 \\
\hline & lodo & 350 & 178 & - & & \\
\hline
\end{tabular}

cálculo da remoção considerou o número mínimo detectável $\left(\log _{10}\right.$ conc.água bruta $-\log _{10}$ "número mínimo detectável") ;*valor correspondente ao número de (oo)cistos nos $12 \mathrm{~L}$ de todos os jarros do jarteste, para água bruta.;**valor calculado conforme Equação 4

Os resultados da segunda condição de coagulação $\left(65 \mathrm{mg} . \mathrm{L}^{-1}\right.$ de PAC e $15 \mathrm{mg} . \mathrm{L}^{-1}$ de $\mathrm{NaOH}$ ) apresentam-se na Tabela 5.23. A porcentagem média de recuperação de oocistos de $C$. parvum foi de $21 \%$ com um coeficiente de variação de $117 \%$. A eficiência média de remoção na decantação foi de $2,3 \pm 0,73 \log _{10}$ e após o filtro foi de $2,19 \pm 0,06 \log _{10}$.

De forma diferente da primeira condição de coagulação, foi identificado oocistos de $C$. parvum nos efluente dos filtros em todos os testes. Esta constatação pode ser um indicativo de melhor desempenho da primeira condição de coagulação na remoção de oocistos de $C$. parvum. 
Tabela 5.23- Número de oocistos de $C$. parvum por litro nos ensaios de tratabilidade para a segunda condição de coagulação (dose de 65 mg. $\mathrm{L}^{-1}$ de PAC e 15 mg.L $\mathrm{L}^{-1}$ de $\left.\mathrm{NaOH}\right)$ com o emprego de purificação por IMS e remoção $\left(\log _{10}\right)$

\begin{tabular}{|c|c|c|c|c|c|c|}
\hline \multirow[t]{2}{*}{ Teste } & \multirow[t]{2}{*}{$\begin{array}{l}\text { Tipo de } \\
\text { amostra }\end{array}$} & \multirow{2}{*}{$\begin{array}{c}\text { Número } \\
\text { de oocistos } \\
\text { na amostra } \\
\text { composta } \\
(*),(* *)\end{array}$} & \multicolumn{2}{|c|}{$\begin{array}{c}\mathrm{N}^{\mathrm{o}} \text { de oocistos de } \\
\text { C. parvum por litro } \\
\left(\text { cistos. } \mathrm{L}^{-1}\right)\end{array}$} & \multirow{2}{*}{$\begin{array}{c}\text { Porcentagem } \\
\text { de } \\
\text { recuperação }\end{array}$} & \multirow[t]{2}{*}{$\begin{array}{l}\text { Remoção } \\
\left(\text { em } \log _{10}\right)\end{array}$} \\
\hline & & & Enumerado & Esperado & & \\
\hline \multirow{4}{*}{$\begin{array}{c}2.1 \\
\text { IMS }\end{array}$} & água bruta & 389 & 32 & 500 & $6 \%$ & \\
\hline & água decantada & 1 & $<1$ & - & & 2,21 \\
\hline & água filtrada & 1 & $<1$ & - & & 2,18 \\
\hline & lodo & 18 & 12 & - & & \\
\hline \multirow{4}{*}{$\begin{array}{c}2.2 \\
\text { IMS }\end{array}$} & água bruta & 442 & 37 & 500 & $7 \%$ & \\
\hline & água decantada & 0 & 0 & - & & $>1,6$ \\
\hline & água filtrada & 1 & $<1$ & - & & 2,3 \\
\hline & lodo & 0 & 0 & - & & \\
\hline \multirow{4}{*}{$\begin{array}{c}2.3 \\
\text { IMS }\end{array}$} & água bruta & 2894 & 252,0 & 500 & $50 \%$ & \\
\hline & água decantada & 0 & 0 & - & & $>3,1$ \\
\hline & água filtrada & 2 & $<1$ & - & & 2,1 \\
\hline & lodo & 1 & 1,0 & - & & \\
\hline
\end{tabular}

Observações: O símbolo ">” (maior que) indica que não houve detecção de organismo pelo método e o cálculo da remoção considerou o número mínimo detectável $\left(\log _{10}\right.$ conc.água bruta $-\log _{10}$ "número mínimo detectável") ;*valor correspondente ao número de (oo)cistos nos $12 \mathrm{~L}$ de todos os jarros do jarteste, para água bruta.;**valor calculado conforme Equação 4

A identificação de oocistos no lodo apresentou-se muito difícil em todos os testes realizados na segunda condição de coagulação. $O$ aspecto da amostra no poço da lâmina de imunofluorescência era de acentuada espessura e alta densidade, em consequência à expressiva geração de lodo dada adição elevada de PAC. A ação de aumentar o volume de água para ressuspender o lodo nos testes 2.2IMS e 2.3IMS, descrita no item 4.2.2., não acarretou melhora na recuperação de oocistos de C. parvum.

A soma dos organismos detectados em cada etapa não foi semelhante ao detectado na água bruta, possivelmente devido à deficiência da identificação de oocistos no lodo e pela ausência de indivíduos na água decantada. Nota-se que houve identificação de cistos de Giardia spp. na água decantada e praticamente não houve identificação de oocistos de $C$. parvum nesta água. Talvez as dinâmicas de adesão de cistos e oocistos a flocos sejam 
diferentes. Aparenta que haja menor adesão de cistos de Giardia spp., estes possuem um tamanho maior e é mais provável que eles sejam removidos no filtro mesmo não fazendo parte de um floco.

\subsubsection{SÍNTESE DA EFICIÊNCIA DE REMOÇÃo DAS CONDIÇÕES DE COAGULAÇÃO ESTUDADAS}

A Tabela 5.24 apresenta uma síntese dos resultados da remoção de (oo)cistos de Giardia e C. parvum após a filtração. Foram considerados apenas os testes realizados com IMS, pois estes apresentaram número mínimo detectável inferior, o que fornece mais confiabilidade aos resultados.

Tabela 5.24- Remoção de cistos de Giardia spp. e oocistos de $C$. parvum de acordo com diferentes condições de coagulação $\left(\mathrm{C} 1=25 \mathrm{mg} . \mathrm{L}^{-1}\right.$ de PAC, sem correção de pH; C2=65 mg. . $^{-1}$ de PAC, com adição de alcalinizante)

\begin{tabular}{ccc}
\hline \multirow{2}{*}{ Organismo } & \multicolumn{2}{c}{ Remoção expressa em log $\mathbf{1 0}_{10}$} \\
& C1 (número de ensaios =4) & C2 (número de ensaios =3) \\
& \pm d.p. & \pm d.p. \\
\hline Giardia spp. & $3,10 \pm 0,41$ & $2,92 \pm 0,09$ \\
C. parvum & $2,13 \pm 0,44$ & $2,19 \pm 0,06$ \\
\hline
\end{tabular}

O estudo da remoção de (oo)cistos de protozoários analisado por valores de eficiência de remoção é, em certo ponto, problemático. O valor da eficiência da remoção é proporcional à concentração afluente destes organismos. Nos casos onde não se detectaram (oo)cistos no efluente, considerou-se o valor do número mínimo detectável para o cálculo da eficiência de remoção (eficiência $=\log _{10}$ concentração afluente $-\log _{10}$ número mínimo detectável).

O método não foi capaz de identificar (oo)cistos em muitas ocasiões, isto se deveu, principalmente, ao volume limitado de água filtrada gerado em cada ensaio em escala de bancada (inferior a 6 litros). Segundo resultados de Ongergth e Saaed (2013), o nível mínimo prático em que os organismos podem ser contados e manipulados é de $50 \mathrm{~L}$ e 10 oocistos.

No caso dos dados apresentados na Tabela 5.24, pela análise única destes resultados, não houve diferença significativa de eficiência de remoção entre as duas condições estudadas pelo teste ANOVA, a um nível de confiança de 95\%. Outra abordagem sobre a avaliação das duas condições de coagulação é apresentada na seção 5.5.2. 
Assavasilavasukul (2008) realizou experimentos com variações de remoção de 0,73 a 5,2 $\log _{10}$ e 1,0 a 5,4 $\log _{10}$, para Cryptosporidium spp. e Giardia spp., respectivamente. Segundo o autor, além de variações na concentração afluente, a turbidez da água e os métodos de amostragem contribuíram para as diferenças observadas na capacidade de remoção destes patógenos no tratamento convencional. No presente estudo, embora tenha sido buscada a homogeneidade de condição para todos os testes, houve variação significativa da identificação de (oo)cistos na água afluente (água de estudo). A variação é inerente ao método de identificação.

\subsection{COMPARAÇÃO ENTRE OS PROCEDIMENTOS SEM E COM A ETAPA DE PURIFICAÇÃO POR IMS}

Os testes de identificação de protozoários nas fases água bruta e água filtrada do ensaio de tratabilidade foram realizados com a divisão do volume do sedimento concentrado entre as metodologias sem e com purificação por IMS. Esta conduta possibilitou que se analisasse o desempenho em paralelo das duas metodologias.

A Tabela 5.25 apresenta um comparativo da identificação de cistos de Giardia spp. na água bruta entre os dois procedimentos discutidos, ao longo dos 7 testes realizados. A média de recuperação foi de $63 \%$ e o coeficiente de variação de $60 \%$ nos testes em que houve o procedimento de IMS. Para os testes sem o emprego da separação imunomagnética, a média de recuperação foi de $112 \%$ e o coeficiente de variação foi de $46 \%$.

Quanto à identificação de oocistos de C. parvum, os resultados são apresentados na Tabela 5.26. Para o procedimento com IMS, a média de recuperação foi de $15 \%$ e o coeficiente de variação foi de $115 \%$. No procedimento sem IMS foi obtida uma média de recuperação de $22 \%$ e coeficiente de variação de $78 \%$

A comparação entre os diversos ensaios demonstra que o procedimento de identificação de protozoários sem a etapa de purificação por IMS alcançou resultados mais aceitáveis de que quando esta etapa era incluída. Tal constatação é válida tanto para recuperação de cistos de Giardia spp. quanto para a de oocistos de C. parvum (Tab. 5.24 e 5.25). 
Tabela 5.25- Comparação da eficiência de recuperação de cistos de Giardia spp. entre as metodologias com e sem o emprego da separação imunomagnética (IMS) - na água bruta

\begin{tabular}{|c|c|c|c|c|c|}
\hline \multirow{2}{*}{$\begin{array}{l}\text { Número do } \\
\text { teste }\end{array}$} & \multirow{2}{*}{$\begin{array}{c}\text { Concentração } \\
\text { esperada } \\
\text { na amostra } \\
\text { composta } \\
\left(\text { cistos.L } L^{-1}\right)\end{array}$} & \multicolumn{2}{|c|}{$\begin{array}{c}\text { Concentração } \\
\text { identificada na amostra } \\
\text { composta }\left(\text { cistos. } \mathrm{L}^{-1}\right)\end{array}$} & \multicolumn{2}{|c|}{$\begin{array}{l}\text { Porcentagem de } \\
\text { recuperação (\%) }\end{array}$} \\
\hline & & com IMS & sem IMS & com IMS & sem IMS \\
\hline 1.1 & 500 & 576 & 695 & $115 \%$ & $139 \%$ \\
\hline 1.2 & 500 & 512 & 532 & $102 \%$ & $106 \%$ \\
\hline 1.3 & 500 & 180 & 516 & $36 \%$ & $103 \%$ \\
\hline 1.4 & 500 & 79 & 316 & $16 \%$ & $63 \%$ \\
\hline 2.1 & 500 & 164 & 333 & $33 \%$ & $67 \%$ \\
\hline 2.2 & 500 & 416 & 450 & $83 \%$ & $90 \%$ \\
\hline \multirow[t]{2}{*}{2.3} & 500 & 272 & 1067 & $54 \%$ & $213 \%$ \\
\hline & & & $\begin{array}{c}\text { Média } \\
\text { Coeficiente } \\
\text { de variação } \\
\text { (CV) }\end{array}$ & $63 \%$ & $112 \%$ \\
\hline
\end{tabular}

Tabela 5.26- Comparação da eficiência de recuperação de oocistos de $C$. parvum entre as metodologias com e sem o emprego da separação imunomagnética (IMS) - na água bruta

\begin{tabular}{|c|c|c|c|c|c|}
\hline \multirow{2}{*}{$\begin{array}{l}\text { Número do } \\
\text { teste }\end{array}$} & \multirow{2}{*}{$\begin{array}{l}\text { Concentração } \\
\text { esperada na } \\
\text { amostra } \\
\text { composta } \\
\left(\text { oocistos.L }{ }^{-1}\right)\end{array}$} & \multicolumn{2}{|c|}{$\begin{array}{c}\text { Concentração identificada na } \\
\text { amostra composto } \\
\left(\text { oocistos.L } L^{-1}\right)\end{array}$} & \multicolumn{2}{|c|}{$\begin{array}{l}\text { Porcentagem de } \\
\text { recuperação (\%) }\end{array}$} \\
\hline & & $\begin{array}{l}\text { com } \\
\text { IMS }\end{array}$ & sem IMS & com IMS & sem IMS \\
\hline 1.1 & 500 & 12 & 17 & $2 \%$ & $3 \%$ \\
\hline 1.2 & 500 & 14 & 81 & $3 \%$ & $16 \%$ \\
\hline 1.3 & 500 & 111 & 64 & $22 \%$ & $13 \%$ \\
\hline 1.4 & 500 & 62 & 100 & $12 \%$ & $20 \%$ \\
\hline 2.1 & 500 & 32 & 50 & $6 \%$ & $10 \%$ \\
\hline 2.2 & 500 & 37 & 200 & $7 \%$ & $40 \%$ \\
\hline \multirow[t]{3}{*}{2.3} & 500 & 252 & 250 & $50 \%$ & $50 \%$ \\
\hline & & & Média & $15 \%$ & $22 \%$ \\
\hline & & & $\begin{array}{c}\text { Coeficiente de variação } \\
\text { (CV) }\end{array}$ & $115 \%$ & $78 \%$ \\
\hline
\end{tabular}


Ressalta-se que estas análises foram realizadas em águas com concentração elevada de cistos de Giardia spp. e oocistos de C. parvum. Adiciona-se ainda que o estudo se baseia em uma água de estudo com turbidez aumentada por caulinita. Águas naturais podem possuir interferentes que inviabilizem o bom desempenho de testes sem a etapa de purificação por IMS.

Uma comparação também pôde ser estabelecida quanto à identificação de cistos de Giardia spp. e oocistos de C. parvum na água filtrada. Os resultados desta comparação são apresentados na Tabela 5.27, para os resultados da primeira condição de coagulação e Tabela 5.28, para os resultados da segunda condição de coagulação.

Tabela 5.27- Comparação entre o número de (oo)cistos detectados no fim do tratamento, para a primeira condição de coagulação (dosagem de $25 \mathrm{mg}^{-L^{-1}}$ de PAC e ausência de correção de pH), entre as metodologias com e sem o emprego da separação imunomagnética (IMS) - água após filtração

\begin{tabular}{ccccc}
\hline Número do teste & \multicolumn{2}{c}{$\mathbf{N}^{\mathbf{0}}$ de cistos de Giardia spp. } & \multicolumn{2}{c}{$\mathbf{N}^{\mathbf{0}}$ de oocistos de C. parvum } \\
por litro (cistos. p $^{-1}$ ) & por litro (oocistos. ( $^{-\mathbf{1}}$ ) \\
& com IMS & sem IMS & com IMS & sem IMS \\
\hline 1.1 & 0,20 & 0 & 0 & 0 \\
\hline 1.2 & 0,20 & 0 & 0 & 0 \\
\hline 1.3 & 0 & 0 & 0 & 0 \\
\hline 1.4 & 0,20 & 0 & 0,42 & 0 \\
\hline Média & 0,15 & 0 & 0,14 & \\
\hline Desvio padrão & 0,10 & & 0,21 & \\
\hline
\end{tabular}

Tabela 5.28- Comparação entre o número de (oo)cistos no fim do tratamento, para a segunda condição de coagulação (dosagem de 65 mg. $\mathrm{L}^{-1}$ de PAC e 15 mg.L ${ }^{-1}$ de $\mathrm{NaOH}$ ), entre as metodologias com e sem o emprego da separação imunomagnética (IMS) - água após filtração.

\begin{tabular}{ccccc}
\hline Número do teste & \multicolumn{2}{c}{$\mathbf{N}^{\mathbf{0}}$ de cistos de Giardia spp. } & \multicolumn{2}{c}{$\mathbf{N}^{\mathbf{0}}$ de oocistos de C. parvum } \\
& por litro (cistos. $\mathbf{L}^{-\mathbf{1}}$ ) & \multicolumn{2}{c}{ por litro (oocistos. $\mathbf{L}^{\mathbf{- 1}}$ ) } \\
com IMS & sem IMS & com IMS & sem IMS \\
\hline 2.1 & 0,21 & 0 & 0,21 & 0 \\
\hline 2.2 & 0,39 & 3 & 0,20 & 3 \\
\hline 2.3 & 0,39 & 0 & 0,4 & 0 \\
\hline Média & 0,30 & 1 & 0,26 & 1 \\
Desvio padrão & 0,10 & 1,73 & 0,10 & 1,73 \\
\hline
\end{tabular}


Observou-se que na primeira condição de coagulação (Tab. 5.26), não foram identificados (oo)cistos sem uso do IMS. Já quando houve purificação por IMS, a média da concentração identificada foi de 0,15 cistos de Giardia spp. por $\operatorname{litro}^{4}$ e 0,14 oocistos de $C$. parvum por litro. O valor não inteiro se refere à identificação de um organismo em volume superior a um litro. Neste estudo, usualmente se identificou um (oo)cisto em todo volume analisado de água filtrada, que era superior a 5 litros.

Para a segunda condição de coagulação (Tab. 5.27), todos os testes com o emprego de IMS foram capazes de identificar (oo)cistos. Nestes casos, a média da concentração de cistos de Giardia spp. foi de 0,30 cistos por litro, a média da concentração de oocistos de C. parvum foi de 0,26 oocistos por litro.

Ainda sobre a segunda condição de coagulação, houve identificação de (oo)cistos mesmo sem o emprego de IMS no teste 2.2. Esta identificação de 1 cisto e 1 oocisto implicou no valor de concentração de 3 cistos e 3 oocistos por litro, isto ocorreu pelo elevado número mínimo detectável da metodologia de identificação de protozoários sem o procedimento de purificação por IMS. O número mínimo detectável do método, dado pela Equação 2, para este teste foi de 2,62 (oo) cistos. $\mathrm{L}^{-1}$.

Um número mínimo detectável elevado implica em inviabilidade no uso do método sem IMS para análise de águas com concentração baixa de (oo)cistos. Para que o número mínimo detectável seja baixo, é necessária a análise de um grande volume de água. A metodologia de identificação de protozoários sem purificação por IMS não é recomendada para o estudo de água efluente dos FLA.

A análise da decisão quanto ao emprego da purificação por IMS deve ser baseada, portanto, na qualidade esperada da água, no volume disponível ou possível de ser analisado, além do critério econômico. A Tabela 5.29 apresenta o consumo de reagentes utilizados nos procedimentos de identificação com e sem IMS, para a água de estudo com turbidez elevada, além do custo. Em junho de 2014, o Kit Merifluor ${ }^{\circledR}$ (Meridian Bioscience) para 50 testes foi orçado pelo distribuidor autorizado no Brasil em R\$ 5.828,61. No mesmo mês, o kit Dynabeads ${ }^{\circledR}$ (IDDEX), também para 50 testes, foi orçado em R\$ 18.000,00. Segundo a Tabela 5.29, o valor do ensaio com IMS é 1,73\% maior quando comparado ao teste sem IMS,

\footnotetext{
${ }^{4}$ Optou-se por expressar em termos decimais a concentração de (oo)cistos de Giardia e Cryptosporidium na "água filtrada" por essa forma se apresentar com mais exatidão. Os volumes de "água filtrada" produzido em cada ensaio variaram e o número decimal da concentração é resultado da divisão do número de (oo)cistos (normalmente 1) pelo volume de "água filtrada"
} 
não considerados os outros reagentes necessários à avaliação de protozoários em amostras de água.

Tabela 5.29- Comparativo econômico entre as análises com e sem a etapa de purificação por IMS para uma água de estudo com turbidez em torno de 120 uT (valores de junho de 2014)

\begin{tabular}{cccc}
\hline & \multicolumn{2}{c}{ Consumo } & Testes Kit Merifluor ${ }^{\circledR}$ \\
necessários & Testes kit Dynabeads ${ }^{\circledR}$ & $\begin{array}{c}\text { Custo do } \\
\text { teste }\end{array}$ \\
\hline $\begin{array}{c}\text { Teste com } \\
\text { IMS } \\
\text { Teste sem } \\
\text { IMS }\end{array}$ & 2 & 1 & $\mathrm{R} \$ 593,14$ \\
\hline
\end{tabular}

5.7. ESTUDO DA DISTRIBUIÇÃO DA RECUPERAÇÃO DE CISTOS DE GIARDIA SPP. E OOCISTOS DE C. PARVUM NAS DISSOCIAÇÕES ÁCIDAS DO PROCEDIMENTO COM IMS

O Método USEPA 1623.1 recomenda que haja duas dissociações ácidas no fim do procedimento de purificação por IMS. Esta etapa pode ser feita em dois poços ou mesmo em um único poço da lâmina de imunofluorescência. Nesta pesquisa, realizaram-se as duas dissociações ácidas em poços distintos. A principal justificativa para esta decisão foi a dificuldade em se trabalhar com um volume superior a $55 \mu \mathrm{L}$ nos poços das lâminas do kit Merifluor ${ }^{\circledR}$.

A divisão das dissociações em poços independentes possibilitou uma análise do comportamento de cistos de Giardia spp. e oocistos de C. parvum quanto a interação destes com as microesferas magnéticas. As Tabelas 5.30 e 5.31 apresentam o resultado da distribuição da recuperação de cistos de Giardia spp. e de oocistos de C. parvum, respectivamente, em cada teste.

A baixa identificação de (oo)cistos nas amostras de água decantada e água filtrada fez com que se tornasse difícil uma análise comparativa da recuperação de acordo com as dissociações nestas. Por outro lado, os resultados das análises de água bruta são mais consistentes e é possível observar comportamento semelhante entre os testes. Pela Tabela 5.30, observa-se que a segunda dissociação de cistos de Giardia spp. ocorreu de forma melhor sucedida que a primeira (à exceção do teste 2.2), a média de recuperação foi superior estatisticamente, segundo teste ANOVA a um nível de significância de 95\% $(p=0,003)$. O mesmo comportamento não se observa na Tabela 5.31, quando a primeira dissociação de 
oocistos de C. parvum foi melhor sucedida, segundo teste ANOVA, a um nível de significância de $95 \%(p=0,03)$.

Tabela 5.30- Distribuição da porcentagem de recuperação de cistos de Giardia spp. entre a primeira e segunda dissociação ácida no procedimento de IMS

\begin{tabular}{ccccccccc}
\hline \multirow{2}{*}{ Número do teste } & \multicolumn{2}{c}{ água bruta } & \multicolumn{2}{c}{ água decantada } & \multicolumn{2}{c}{ água filtrada } & \multicolumn{2}{c}{ lodo } \\
& $\mathbf{1}^{\mathbf{a}}$ & $\mathbf{2}^{\mathbf{a}}$ & $\mathbf{1}^{\mathbf{a}}$ & $\mathbf{2}^{\mathbf{a}}$ & $\mathbf{1}^{\mathbf{a}}$ & $\mathbf{2}^{\mathbf{a}}$ & $\mathbf{1}^{\mathbf{a}}$ & $\mathbf{2}^{\mathbf{a}}$ \\
\hline 1.1 & $36 \%$ & $64 \%$ & $0 \%$ & $100 \%$ & $0 \%$ & $100 \%$ & $24 \%$ & $76 \%$ \\
\hline 1.2 & $19 \%$ & $81 \%$ & $89 \%$ & $11 \%$ & $100 \%$ & $0 \%$ & $90 \%$ & $10 \%$ \\
\hline 1.3 & $45 \%$ & $55 \%$ & - & - & - & - & $56 \%$ & $44 \%$ \\
\hline 1.4 & $43 \%$ & $57 \%$ & - & - & - & - & $6 \%$ & $94 \%$ \\
\hline 2.1 & $12 \%$ & $88 \%$ & $62 \%$ & $38 \%$ & $0 \%$ & $100 \%$ & $29 \%$ & $71 \%$ \\
\hline 2.2 & $58 \%$ & $42 \%$ & $50 \%$ & $50 \%$ & $100 \%$ & $0 \%$ & $69 \%$ & $31 \%$ \\
\hline 2.3 & $15 \%$ & $85 \%$ & $0 \%$ & $100 \%$ & $0 \%$ & $100 \%$ & $53 \%$ & $47 \%$ \\
\hline Média & $32 \%$ & $68 \%$ & $40 \%$ & $60 \%$ & $40 \%$ & $60 \%$ & $47 \%$ & $53 \%$ \\
Desvio padrão & $17 \%$ & $17 \%$ & $39 \%$ & $39 \%$ & $55 \%$ & $55 \%$ & $29 \%$ & $29 \%$ \\
\hline
\end{tabular}

Observações: $1^{\text {a }}$ primeira dissociação; e $2^{\mathrm{a}}$ segunda dissociação. “.” significa que não houve identificação de cistos no teste

Tabela 5.31- Distribuição da porcentagem de recuperação de oocistos de $C$. parvum entre a primeira e a segunda dissociação ácida do procedimento de IMS

\begin{tabular}{ccccccccc}
\hline \multirow{2}{*}{ Número do teste } & \multicolumn{2}{c}{ água bruta } & \multicolumn{2}{c}{ água decantada } & \multicolumn{2}{c}{ água filtrada } & \multicolumn{2}{c}{ lodo } \\
& $\mathbf{1}^{\mathbf{a}}$ & $\mathbf{2}^{\mathbf{a}}$ & $\mathbf{1}^{\mathbf{a}}$ & $\mathbf{2}^{\mathbf{a}}$ & $\mathbf{1}^{\mathbf{a}}$ & $\mathbf{2}^{\mathbf{a}}$ & $\mathbf{1}^{\mathbf{a}}$ & $\mathbf{2}^{\mathbf{a}}$ \\
\hline 1.1 & $62 \%$ & $38 \%$ & - & - & - & - & $0 \%$ & $100 \%$ \\
\hline 1.2 & $53 \%$ & $47 \%$ & $0 \%$ & $100 \%$ & - & - & $100 \%$ & $0 \%$ \\
\hline 1.3 & $86 \%$ & $14 \%$ & - & - & - & - & - & - \\
\hline 1.4 & $67 \%$ & $33 \%$ & - & - & $100 \%$ & $0 \%$ & $17 \%$ & $83 \%$ \\
\hline 2.1 & $59 \%$ & $41 \%$ & $100 \%$ & $0 \%$ & $100 \%$ & $0 \%$ & $0 \%$ & $100 \%$ \\
\hline 2.2 & $43 \%$ & $57 \%$ & - & - & $0 \%$ & $100 \%$ & - & - \\
\hline 2.3 & $46 \%$ & $54 \%$ & - & - & $100 \%$ & $0 \%$ & $0 \%$ & $100 \%$ \\
\hline Média & $59 \%$ & $41 \%$ & $50 \%$ & $50 \%$ & $75 \%$ & $25 \%$ & $23 \%$ & $77 \%$ \\
Desvio padrão & $14 \%$ & $14 \%$ & $71 \%$ & $71 \%$ & $50 \%$ & $50 \%$ & $43 \%$ & $43 \%$ \\
\hline
\end{tabular}

Observação: $1^{\text {a }}$ primeira dissociação; e $2^{\mathrm{a}}$ segunda dissociação. "“" significa que não houve identificação de oocistos no teste

A respeito destes resultados, estabelece-se a hipótese de que a interação dos cistos de Giardia spp. com as microesferas Dynabeads ${ }^{\circledR}$ Anti-Giardia seja mais forte que a interação 
dos oocistos de C. parvum com as microesferas Dynabeads ${ }^{\circledR}$ Anti-Cryptosporidium. Esta sugestão é baseada também em análise qualitativa das imagens de microscopia. Algumas imagens mostraram cistos de Giardia spp. ainda aderidos à microesferas (Figura 5.14) após a dissociação ácida, fato que não foi observado nas visualizações de oocistos de C. parvum.
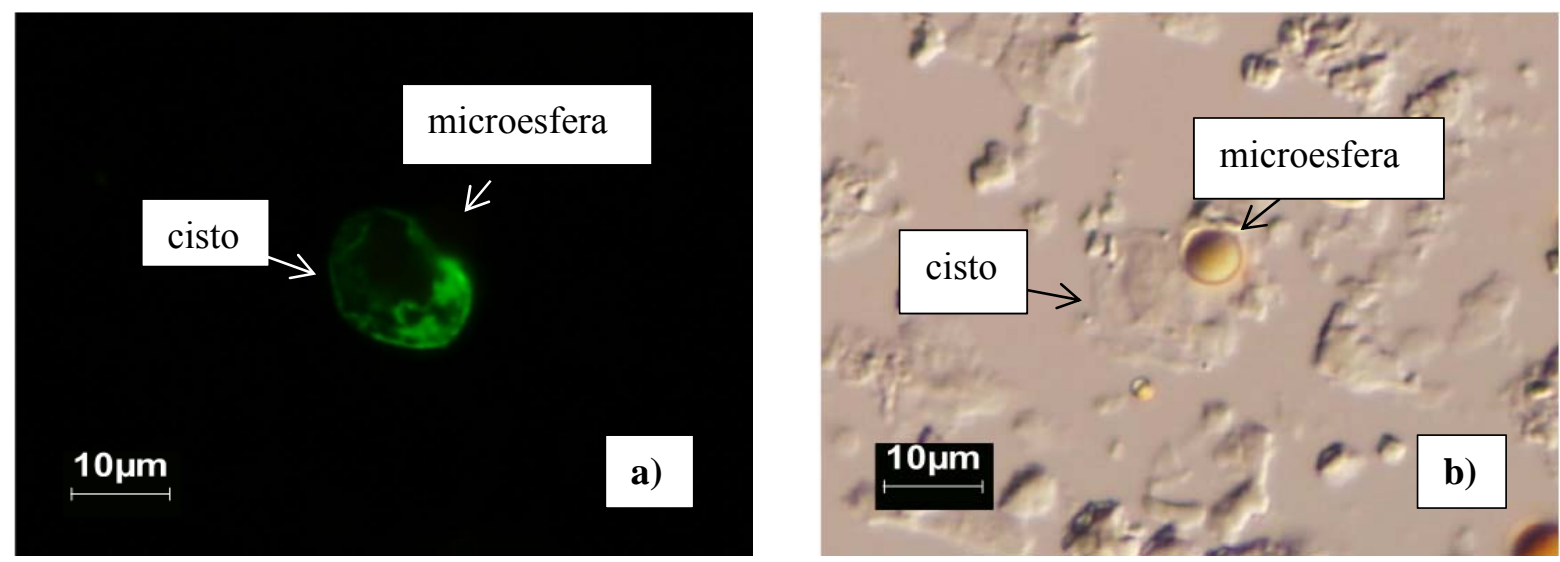

Figura 5.14- Imagem de cisto de Giardia spp. aderido à uma microesfera magnética. a) visualização em RID; b) visualização em DIC (Aum: 400x)

A respeito dos resultados de recuperação nas amostras de lodo, não é possível se estabelecer comparações, pois a identificação de oocistos de C. parvum nestas amostras foi deficiente. Quanto à recuperação de cistos de Giardia spp., não houve diferença na estatística na média da distribuição da porcentagem de recuperação entre as duas dissociações, segundo teste ANOVA, a um nível de significância de 95\%. Independente da prevalência da primeira ou segunda dissociação ácida é indispensável que este procedimento de dupla dissociação seja realizado.

\subsection{AVALIAÇÃO DO DESEMPENHO DAS DUAS CONDIÇÕES DE COAGULAÇÃO PROPOSTAS NA REMOÇÃO DE CISTOS DE GIARDIA SPP. E OOCISTOS DE C. PARVUM}

Os resultados apresentados no item 5.4.2 apontam um provável melhor desempenho da primeira condição de coagulação (dosagem $25 \mathrm{mg} \cdot \mathrm{L}^{-1}$ de PAC e ausência de correção de $\mathrm{pH}$ ) em comparação com a segunda (dosagem de $65 \mathrm{mg} . \mathrm{L}^{-1}$ e $15 \mathrm{mg} . \mathrm{L}^{-1}$ de $\mathrm{NaOH}$ ) na remoção de (oo)cistos de protozoários. Esta sugestão está baseada nos resultados de identificação de protozoários nas águas efluentes dos FLA. Para esta melhor condição houve teste em que não se detectou a presença de Giardia spp. e nem de C. parvum (teste 1.3).

O experimento proposto não apresentou um número significativo de testes. No entanto, a observação das variáveis de coagulação (Tabela 5.32) e variáveis físicas e químicas do 
tratamento (Tabela 5.33) se exibem como auxiliares importantes na interpretação dos resultados.

A respeito das variáveis de coagulação, observa-se algumas diferença entre as duas condições estudadas. Para a condição de menor dosagem de coagulante (testes 1.1 a 1.4) observa-se $\mathrm{pH}$ inferior a 7 e potencial zeta positivo, o que indica que houve o fenômeno de reversão de cargas. A maior dosagem de coagulante apresentou $\mathrm{pH}$ superior a 7 e potencial zeta negativo e mais elevado. A diferença entre as duas faixas de valores de potencial zeta e pH aparentam ter papéis importantes na dinâmica dos (oo)cistos durante os ensaios de tratabilidade.

A respeito das variáveis físicas e químicas analisadas, os resultados presentes na Tabela 5.33, talvez apenas os valores de $\mathrm{pH}$ possam ser relacionados ao desempenho da remoção de (oo)cistos de protozoários (se explica nas seções 5.8.1. e 5.8.2.). Embora tenha havido uma diferença na média da turbidez na água filtrada, de forma geral, os dois tratamentos apresentaram desempenhos semelhantes. A diferença na média das leituras de turbidez é explicada pelo alto valor indicado no teste 2.3. Este teste apresentou, isoladamente, algum problema de desempenho.

As duas condições de coagulação apresentaram resultados finais distintos a respeito da alcalinidade e do $\mathrm{pH}$. Estes resultados eram esperados, uma vez que houve elevada dosagem de alcalinizante na segunda condição de coagulação. 
Tabela 5.32- Variáveis de coagulação relacionadas às concentrações de cistos de Giardia spp. e oocistos de C. parvum na água bruta(AB) e “agua filtrada” (AF), na: primeira condição de coagulação (25 mg.L ${ }^{-1}$ de PAC, sem correção de pH) (testes 1.1 a 1.4$)$; segunda condição de coagulação (65 mg. $\mathrm{L}^{-1}$ de PAC com adição de alcalinizante) (testes 2.1 a 2.3); ND- não detectado pelo método

\begin{tabular}{|c|c|c|c|c|c|c|c|c|c|c|c|}
\hline \multirow{4}{*}{$\begin{array}{l}\text { Número do } \\
\text { teste }\end{array}$} & \multicolumn{3}{|c|}{ Variáveis de coagulação } & \multicolumn{8}{|c|}{ Concentração de (oo)cistos ( (oo)cistos $\left.L^{-1}\right)$} \\
\hline & \multirow{3}{*}{$\mathbf{p H}$} & \multirow{3}{*}{$\begin{array}{c}\text { Potencial } \\
\text { Zeta } \\
(\mathrm{mV})^{*}\end{array}$} & \multirow{3}{*}{$\begin{array}{c}\text { Condutividade } \\
\text { (mS.cm-1) }\end{array}$} & \multicolumn{4}{|c|}{ Giardia spp. } & \multicolumn{4}{|c|}{ C. parvum } \\
\hline & & & & \multicolumn{2}{|c|}{ com IMS } & \multicolumn{2}{|c|}{ sem IMS } & \multicolumn{2}{|c|}{ com IMS } & \multicolumn{2}{|c|}{ sem IMS } \\
\hline & & & & $\mathbf{A B}$ & AT & $\mathbf{A B}$ & AT & $\mathbf{A B}$ & AT & $\mathbf{A B}$ & AT \\
\hline 1.1 & 6,70 & 8,68 & 0,0612 & 576 & 0,20 & 695 & ND & 12 & $\mathrm{ND}$ & 17 & ND \\
\hline 1.2 & 6,88 & 4,74 & 0,0660 & 512 & 0,20 & 532 & ND & 14 & ND & 81 & ND \\
\hline 1.3 & 6,77 & 8,29 & 0,0607 & 180 & $\mathrm{ND}$ & 517 & ND & 111 & ND & 64 & ND \\
\hline Desvio padrão & 0,08 & 1,78 & 0,0052 & 244 & 0,12 & 155 & & 47 & 0,21 & 35 & \\
\hline 2.1 & 7,07 & $-13,60$ & 0,1020 & 164 & 0,21 & 333 & ND & 32 & 0,21 & 50 & ND \\
\hline 2.2 & 7,40 & $-16,60$ & 0,1020 & 416 & 0,39 & 450 & 2,62 & 37 & 0,20 & 200 & 2,62 \\
\hline 2.3 & 7,40 & $-14,10$ & 0,1060 & 272 & 0,38 & 1067 & ND & 252 & 0,38 & 250 & ND \\
\hline Média & 7,29 & $-14,77$ & 0,1033 & 284 & 0,33 & 617 & 0,87 & 107 & 0,26 & 167 & 0,87 \\
\hline
\end{tabular}

*Potencial zeta da água bruta: $-21,8 \mathrm{mV}$; ND: Não detectado 
Tabela 5.33- Variáveis físicas e químicas relacionadas às concentrações de cistos de Giardia spp. e oocistos de $C$. parvum na água bruta(AB) e "agua filtrada” (AF), na: primeira condição de coagulação (25 mg.L ${ }^{-1}$ de PAC, sem correção de pH) (testes 1.1 a 1.4$)$; segunda condição de coagulação (65 mg.L ${ }^{-1}$ de PAC com adição de alcalinizante) (testes 2.1 a 2.3); ND- não detectado pelo método

\begin{tabular}{|c|c|c|c|c|c|c|c|c|c|c|c|c|c|c|c|c|}
\hline \multirow{3}{*}{$\begin{array}{c}\text { Número do } \\
\text { teste }\end{array}$} & \multicolumn{8}{|c|}{ Variáveis físicas e químicas } & \multicolumn{8}{|c|}{ Concentração de (oo)cistos ( (oo)cistos.L ${ }^{-1}$ ) } \\
\hline & \multicolumn{2}{|c|}{$\begin{array}{l}\text { Turbidez } \\
\text { (uT) }\end{array}$} & \multicolumn{2}{|c|}{ Cor aparente (Pt.Co) } & \multicolumn{2}{|c|}{$\begin{array}{c}\text { Alcalinidade } \\
\left(\text { mg CaCO3.L }^{-1}\right)\end{array}$} & \multicolumn{2}{|c|}{ pH } & \multicolumn{4}{|c|}{ Giardia spp. } & \multicolumn{4}{|c|}{ C. parvum } \\
\hline & AB & AT & $\mathbf{A B}$ & AT & AB & AT & $\mathbf{A B}$ & AT & \multicolumn{2}{|c|}{ com IMS } & \multicolumn{2}{|c|}{ sem IMS } & \multicolumn{2}{|c|}{ com IMS } & \multicolumn{2}{|c|}{ sem IMS } \\
\hline 1.1 & 130,00 & 0,19 & 618 & $<1$ & 28,23 & 18,21 & 7,60 & 7,10 & 576 & 0,20 & 695 & ND & 12 & ND & 17 & ND \\
\hline 1.2 & 125,00 & 0,25 & 574 & $<1$ & 26,96 & 18,14 & 7,64 & 7,14 & 512 & 0,20 & 532 & $\mathrm{ND}$ & 14 & ND & 81 & ND \\
\hline 1.3 & 125,00 & 0,30 & 690 & $<1$ & 25,85 & 16,89 & 7,44 & 7,11 & 180 & ND & 517 & $\mathrm{ND}$ & 111 & ND & 64 & ND \\
\hline Média & 128,00 & 0,25 & 671 & & 27,04 & 17,83 & 7,53 & 7,14 & 337 & 0,10 & 515 & & 50 & 0,10 & 65 & \\
\hline Desvio padrão & 3,56 & 0,05 & 100 & & 0,97 & 0,63 & 0,11 & 0,05 & 244 & 0,12 & 155 & & 47 & 0,21 & 35 & \\
\hline 2.1 & 125,00 & 0,32 & 560 & $<1$ & 26,49 & 25,00 & 7,57 & 7,32 & 164 & 0,21 & 333 & $\mathrm{ND}$ & 32 & 0,21 & 50 & ND \\
\hline 2.2 & 126,00 & 0,25 & 554 & $<1$ & 26,80 & 24,90 & 7,80 & 7,38 & 416 & 0,39 & 450 & 2,62 & 37 & 0,20 & 200 & 2,62 \\
\hline 2.3 & 134,00 & 1,01 & 678 & $<1$ & 25,85 & 24,11 & 7,62 & 7,50 & 272 & 0,38 & 1067 & ND & 252 & 0,38 & 250 & ND \\
\hline
\end{tabular}




\subsubsection{TURBIDEZ FINAL E REMOÇÃO DE PROTOZOÁRIOS}

As duas condições de coagulação deste estudo foram definidas de acordo o desempenho na remoção de turbidez por decantação. No caso da primeira condição de coagulação (dosagem de $25 \mathrm{mg} . \mathrm{L}^{-1}$ de PAC e sem correção de $\mathrm{pH}$ ), atingiu-se a turbidez de 1,60 uT na água decantada, com velocidade de sedimentação de $2 \mathrm{~cm} \cdot \mathrm{min}^{-1}$. A segunda condição (dosagem de $65 \mathrm{mg} . \mathrm{L}^{-1}$ de PAC, sem correção de $\mathrm{pH}$ ), apresentou resultado de turbidez final de 0,72 uT na água decantada, à mesma velocidade de sedimentação.

Quanto à etapa de filtração, o experimento com um kit de 6 filtros de laboratório demonstrou que na primeira condição de coagulação obteve-se turbidez final de 0,31 $\pm 0,08$ uT; já a segunda, 0,30 $\pm 0,04$ uT. Não houve diferença estatística entre essas duas médias, a um nível de significância de 95\%.

Já nos experimentos em escala de bancada realizados com inoculação de protozoários, a primeira condição de coagulação apresentou melhor desempenho que a segunda, os valores de turbidez final foram $0,25 \pm 0,05$ e $0,52 \pm 0,41$, respectivamente, conforme Tabela 5.33. Esta diferença ocorreu principalmente porque um dos experimentos com a segunda condição de coagulação (teste 2.3) apresentou alguma falha operacional, talvez ocorrência de caminhos preferenciais nos filtros. As médias não diferem estatisticamente, segundo teste ANOVA, a um nível de significância de $95 \%$.

No entanto, esta falha não pode ser considerada como a causa do pior desempenho desta condição na remoção de (oo)cistos de Giardia e Cryptosporidium. Os testes 2.1 e 2.2 obtiveram bons desempenhos na remoção de turbidez, mas apresentaram (oo)cistos em suas águas tratadas. Por outro lado, o teste 1.3 apresentou o pior desempenho na remoção de turbidez, dentre os testes da primeira condição de coagulação (turbidez remanescente de $0,30 \mathrm{uT}$ ). Entretanto, no teste 1.3 não foi detectada pelo método analítico a presença de nenhum dos dois protozoários na "água tratada".

Os resultados do presente trabalho demonstraram que a turbidez não é uma variável indicada para o controle da presença de (oo)cistos de protozoários em águas tratadas. É evidente que falhas operacionais nos sistemas de tratamento de águas podem ser identificadas por valores incomuns de turbidez na água final, e, como consequência, os sistemas podem distribuir águas contaminadas por (oo)cistos de protozoários, conforme ocorrido no surto de criptosporidiose de Milwaukee nos EUA 
(MACKENZIE, 1994). No entanto, valores de turbidez como 0,19 uT (teste 1.1, por exemplo), não foram capazes de garantir a ausência destes patógenos.

A falha na coagulação pode causar um sério impacto na remoção de (oo)cistos. No experimento de Emelko (2003), com meios filtrantes duplos (areia e antracito) e triplos (areia, antracito e garnet-granada), houve brusca queda de remoção de oocistos de Cryptosporidium, em ambos meios filtrantes, quando se comparou a operação ótima de coagulação e a coagulação falha. Segundo esta pesquisadora, houve baixa remoção de oocistos em águas com turbidez remanescentes abaixo de 0,3 uT, em operação de falha de coagulação. Esta constatação é semelhante ao que se observou nesta pesquisa, embora a condição de coagulação de maior dosagem não possa ser considerada como falha de coagulação. A estratégia de menor dosagem (primeira condição) pode levar em consideração as variáveis de controle do processo de coagulação para o alcance do bom desempenho na remoção de (oo)cistos.

\subsubsection{VARIÁVEIS DE CONTROLE DA COAGULAÇÃO E REMOÇÃo DE PROTOZOÁRIOS}

A observação da Tabela 5.32 torna claras as diferenças entre as variáveis envolvidas no processo de coagulação entre a primeira e segunda condição de estudo. Inicialmente, foi observado menor valor de $\mathrm{pH}$ para a primeira condição de coagulação. Estudos indicam que ocorre aumento da remoção de oocistos de Cryptosporidium em meios granulares onde o pH é menor (HSU, 2002; TUFENKJI, 2006). O potencial zeta dos oocistos se tornariam menos eletronegativo em menor $\mathrm{pH}$, o que favoreceria o sucesso da retenção dos oocistos no meio filtrante.

Especula-se que a adição de alcalinizante, necessária para atingir bons resultados de turbidez em situações de alta dosagem de coagulante (segunda condição), pode ter prejudicado a remoção de cistos de Giardia e oocistos de Cryptosporidium no meio filtrante de areia. A Tabela 5.34 mostra valores de $\mathrm{pH}$ das amostras de água decantada e água filtrada, para as duas condições de coagulação. Embora a diferença de valores de pH nessas duas condições de coagulação não seja tão pronunciada, ela pode ter contribuído para a diferença nos resultados de remoção de (oo)cistos.

Uma diferença mais evidente de $\mathrm{pH}$ foi experimentada por Fernandes et al. (2010). Neste trabalho, realizaram-se ensaios com filtração direta em escala piloto. Foi observada tendência de melhores remoções de oocistos de Cryptosporidium em pH de coagulação mais baixos, próximos ao valor 5. Embora não haja discussão sobre o pH da 
água decantada, infere-se que este seja baixo. Este resultado vai a encontro das afirmações de Hsu e Huang (2002) e Tufenkji (2006) a respeito da diminuição do pH do meio estar relacionada à diminuição do potencial zeta dos oocistos, com melhores eficiências de colisão entre estes e o meio filtrante (HSU, HUANG e PAN, 2001).

Tabela 5.34- Valores de $\mathrm{pH}$ nas etapas água decantada e água filtrada para : primeira condição de coagulação (25 mg.L $\mathrm{m}^{-1}$ de PAC, sem correção de pH)- testes 1.1 a 1.4; segunda condição de coagulação (65 mg. ${ }^{-1}$ de PAC, com adição de alcalinizante)

\begin{tabular}{ccc}
\hline $\mathbf{N}^{\mathbf{0}}$ do teste & $\mathbf{p H}$ água decantada & $\mathbf{p H}$ água filtrada \\
\hline 1.1 & 7,01 & 7,1 \\
1.2 & 7,06 & 7,14 \\
1.3 & 7,18 & 7,11 \\
1.4 & 7,03 & 7,2 \\
\hline Média & $\mathbf{7 , 0 7}$ & $\mathbf{7 , 1 4}$ \\
Desvio padrão & 0,08 & 0,05 \\
\hline 2.1 & 7,14 & 7,32 \\
2.2 & 7,43 & 7,38 \\
2.3 & 7,55 & 7,5 \\
\hline Média & $\mathbf{7 , 3 7}$ & $\mathbf{7 , 4 0}$ \\
Desvio padrão & 0,21 & 0,09 \\
\hline
\end{tabular}

Os valores de potencial zeta de coagulação, apresentados na Tabela 5.32, também são de interesse de investigação. Não foi encontrado na literatura trabalhos que relacionassem valores de potencial zeta de coagulação à remoção de (oo)cistos de Giardia e Cryptosporidium. No entanto, Bustamante et al. (2001) avaliaram o potencial zeta da superfície de oocistos de Cryptosporidium com o efeito da exposição à diferentes coagulantes.

Os resultados da pesquisa podem se relacionar aos encontrados por Bustamante et al. (2001). Estes pesquisadores mediram o potencial zeta da superfície dos oocistos, em diferentes valores de $\mathrm{pH}$, em amostra com dose de alumínio de $6,8 \mathrm{mg} . \mathrm{L}^{-1}$. O potencial zeta foi positivo a partir do $\mathrm{pH} 4$ até o $\mathrm{pH} 7$, aproximadamente. $\mathrm{O}$ valor do potencial zeta se manteve constante, próximo a $+10 \mathrm{mV}$, entre $\mathrm{pH} 4$ e 6 e, então, houve um 
declínio acentuado entre $\mathrm{pH} 6$ e 7, quando se aproximou à neutralidade de cargas (Figura 5.15). A partir do $\mathrm{pH} 7$, o potencial zeta dos oocistos se tornou consideravelmente mais eletronegativo.

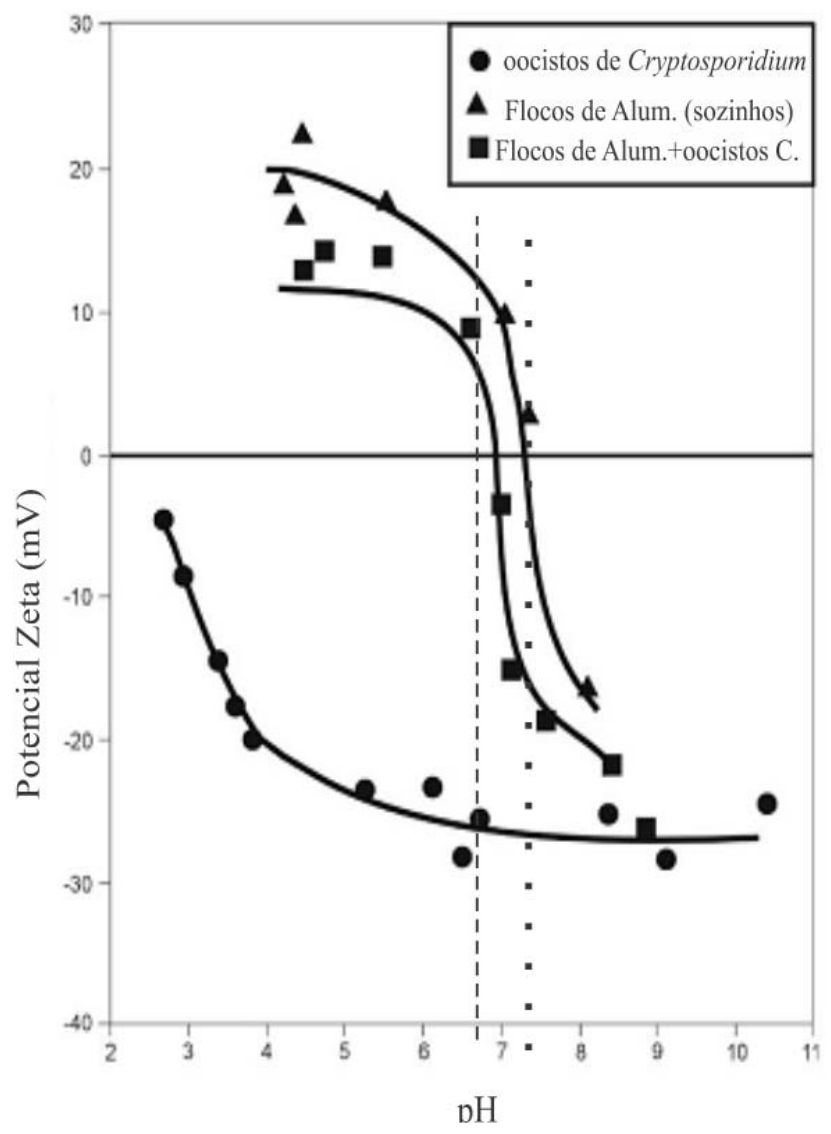

Figura 5.15- Resultados de Bustamante et al.(2001) para o efeito do $\mathrm{pH}$ no potencial zeta de: $(\bullet)$ oocistos de Cryptosporidium; $(\mathbf{\Delta})$ flocos de alumínio sozinhos (sem oocistos); (घ) oocistos na presença de $6,8 \mathrm{mg} . \mathrm{L}^{-1}$ de Alumínio; linha tracejada representa o pH de coagulação da primeira condição de coagulação do presente estudo, a linha pontilhada representa o pH de coagulação da segunda condição (FONTE: Bustamante et al, 2001(adaptado))

De acordo com a Tabela 5.32, a primeira condição de coagulação apresentou o valor de potencial zeta de coagulação de $7,15 \pm 1,78 \mathrm{mV}$ e $\mathrm{pH}$ de coagulação de $6,76 \pm 0,08$. Já a segunda apresentou potencial zeta de coagulação de $-14,77 \pm 1,61$ e pH

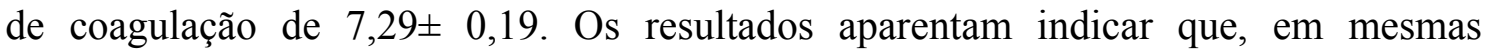
condições de $\mathrm{pH}$, o potencial zeta da soluções analisadas nesta pesquisa, no momento da coagulação, seja semelhante ao potencial zeta da superfície dos oocistos encontrado por 
Bustamante et al. (2001), na presença de coagulantes na forma de alumínio, conforme se observa na Figura 5.15.

Dessa forma, o menor potencial zeta (em módulo) no momento da coagulação pode ser a resposta para o melhor desempenho da primeira condição de coagulação deste estudo em relação à segunda. Esta diferença de potencial zeta pode ter favorecido, por exemplo, o sucesso da colisão entre (oo)cistos e flocos de alumínio, assim como a colisão e retenção dos flocos de alumínio com (oo)cistos no meio filtrante. O fenômeno da reversão de cargas (negativo para positivo), apresentado pela primeira condição de coagulação, também pode ter sido um fator que contribuiu para a melhor remoção de (oo)cistos. 


\section{CONCLUSÕES}

1) A proposta de um modelo multi-variáveis de transmissão da giardiose e criptosporidiose foi capaz de identificar várias possibilidades de ação, diante deste tipo de problema. O componente "contaminação de mananciais" mostrou-se como uma variável-chave no sistema.

2) O coagulante Cloreto de Polialumínio (PAC) é efetivo para o tratamento de águas com turbidez elevada e atingiu 98,6\% e 99,4\% de remoção desta variável nas primeira e segunda condições de coagulação estudadas neste trabalho, respectivamente.

3) O método de concentração de protozoários, descrito por Franco, RochaEberhardt e Cantusio Neto (2001), com adaptações, para água com turbidez elevada, apresentou as seguintes resultados de recuperação: quando não se utilizou a etapa de separação imunomagnética (IMS), para cistos de Giardia spp., obteve-se recuperação de $80 \%$ e CV de $20 \%$, para oocistos de Cryptosporidium, recuperação de 5\% e CV de 115\%; quando se utilizou IMS, para cistos de Giardia, recuperação de $32 \%$ e $\mathrm{CV}$ de $24 \%$, e, oocistos de Cryptosporidium, recuperação de $6 \%$ e CV de $56 \%$.

4) Na primeira condição de coagulação estudada $\left(25 \mathrm{mg} \cdot \mathrm{L}^{-1}\right.$ de PAC e ausência de correção de $\mathrm{pH}$ ), $50 \%$ das amostras analisadas de água filtrada não apresentaram detecção cistos de Giardia e 75\% não apresentaram detecção oocistos de Cryptosporidium. Na segunda condição de coagulação estudada (65 mg. $\mathrm{L}^{-1}$ de PAC, com correção de $\mathrm{pH}$ ), todas as amostras de água analisadas apresentaram detecção de cistos de Giardia e oocistos de Cryptosporidium.

5) As diferenças fundamentais entre as duas condições estudadas de coagulação foram as variáveis de controle da coagulação monitoradas (potencial zeta e pH de coagulação). A potencial zeta positivo e menor em módulo pode explicar o melhor desempenho da primeira condição de coagulação. 


\section{RECOMENDAÇÕES A FUTUROS TRABALHOS}

i) Para estudos em escala de bancada que simulem a tecnologia de ciclo completo, recomenda-se a análise da água de lavagem dos filtros para a realização mais adequada de balanço de massa nestes sistemas;

ii) $\mathrm{O}$ emprego de metodologia diferente da filtração de membranas para a análise de amostras de lodo;

iii) $\mathrm{O}$ uso de alternativas que melhorem o número mínimo detectável em amostras de água filtrada sem o uso de separação imunomagnética (por exemplo, disposição de até 5 alíquotas de $100 \mu \mathrm{L}$ de volume em poços de lâminas de microscopia);

iv) Para o procedimento de concentração de protozoários, recomenda-se reunir o volume correspondente a mais ensaios em escala de bancada para que o volume amostrado de água tratada seja capaz de reduzir o número mínimo detectável das metodologias de identificação de protozoários;

v) Investigar a remoção de (oo)cistos de Giardia e Cryptosporidium em diferentes valores de potencial zeta de coagulação, principalmente em valores próximos à neutralidade de cargas, para a descoberta da melhor estratégia de remoção na ótica desta variável. 


\section{REFERÊNCIAS BIBLIOGRÁFICAS}

ALDOM, J. E.; CHAGLA, A. M. Recovery of Cryptosporidium oocysts from water by a membrane filter dissolution method. Letters in Applied Microbiology, v. 20, n. 3, p. 186$187,1995$.

APHA; AWWA; WEF. Standard Methods for the Examination of Water and Wastewater. Washington. $22^{\circ}$ Ed. EUA, 2012.

ASSAVASILAVASUKUL, P.; et al. Effect of pathogen concentrations on removal of Cryptosporidium and Giardia by conventional drinking water treatment. Water Research, v. 42, n. 10 , p. 2678-2690, 2008.

BALDURSSON, S.; KARANIS, P. Waterborne transmission of protozoan parasites: review of worldwide outbreaks-an update 2004-2010.Water Research, v. 45, n. 20, p. 6603-6614, 2011.

BARROS JUNIOR, A. L. Avaliação da ocorrência de oocistos de Cryptosporidium spp. e cistos de Giardia spp. em amostras de água superficial e da interface sedimento- água do Rio Capivari, na cidade de Campinas, São Paulo, Brasil. Dissertação de Mestrado. Universidade Estadual de Campinas; Instituto de Biologia 2011.

BASTOS, R. K. X. et al. Giardia spp. cysts and Cryptosporidium spp. oocysts dynamics in southeast Brazil: Occurrence in surface water and removal in water treatment processes. Water Science and Technology: Water Supply, v. 4, n. 2, p. 15-22, 2004.

BASTOS, R. K. X. et al. Ocorrência de (oo)cistos de Giardia spp. e Cryptosporidium spp. em Mananciais de Abastecimento de Água em Viçosa-MG. 25 $5^{\circ}$ Congresso Brasileiro de Engenharia Sanitária e Ambiental. Recife-PE, 2009. Anais Eletrônicos: I-327. Recife - PE.

BETANCOURT, W. Q.; ROSE, J. B. Drinking water treatment processes for removal of Cryptosporidium and Giardia. Veterinary Parasitology, v. 126, n. 1-2, Dec 9 2004. ISSN 0304-4017.

BRANCO, N. Avaliação da Presença de Cryptosporidium spp. e Giardia spp em Águas Naturais de Nascentes e Enteroparasitoses em duas Comunidades rurais da Cidade de 
Campos do Jordão, SP, Brasil. Dissertação (Mestrado) - Instituto de Biologia. Universidade Estadual de Campinas, Campinas, 2006.

BRASIL. Ministério da Saúde. Portaria n ${ }^{\circ}$ 2914, de 12 de Dezembro de 2011. Publicada no D.O.U. N² 239, Seção 1, página 39 de 14/12/2011. Brasília.

BUKHARI, Z. et al. Comparison of Cryptosporidium parvum viability and infectivity assays following ozone treatment of oocysts. Applied and Environmental Microbiology, v. 66, n. 7, p. 2972-2980, Jul 2000. ISSN 0099-2240

BUKHARI, Z.; SMITH, H. V. Effect of three concentration techniques on viability of Cryptosporidium parvum oocysts recovered from bovine feces. Journal of Clinical Microbiology, v. 33, n. 10, p. 2592-2595, 1995.

BUSTAMANTE, H. A. et al. Interaction between Cryptosporidium oocysts and water treatment coagulants. Water Research, v. 35, n. 13, p. 3179-3189, Sep 2001. ISSN 00431354.

BUTKUS, M. A.; BAYS, J. T.; LABARE, M. P. Influence of surface characteristics on the stability of Cryptosporidium parvum oocysts. Applied and Environmental Microbiology, v. 69, n. 7, p. 3819-3825, Jul 2003. ISSN 0099-2240.

CACCIO, S.; PUTIGNANI, L. Epidemiology of human Cryptosporidiasis in CACCIO, S. M.; WIDMER, G. editors (2014). Cryptosporidium: parasite and disease. Springer, 2014.

CACCIO, S. M.; SPRONG, H. (2011). Epidemiology of Giardiasis in Humans in LUJÀN, H. D.; SVÄRD, S. editors Giardia: A model Organism. Springer, 2011.

CANTUSIO NETO, R. Ocorrência de oocistos de Cryptosporidium spp. e cistos de Giardia spp. em diferentes pontos do processo de tratamento de água, em Campinas, São Paulo, Brasil. 89p. Dissertação (Mestrado) - Instituto de Biologia. Universidade Estadual de Campinas, Campinas, 2004.

CANTUSIO NETO, R. et al. Cryptosporidium spp. and Giardia spp. in surface water supply of Campinas, Southeast Brazil. Water Science and Technology, v. 62, n. 1, p. 217-222, 2010 2010. ISSN 0273-1223. 
CHO, E.J. et al. A Waterborne Outbreak and Detection of Cryptosporidium Oocysts in Drinking Water of an Older High-Rise Apartment Complex in Seoul. Korean Journal of Parasitology, v. 51, n. 4, p. 461-466, Aug 2013. ISSN 0023-4001.

CLANCY, J. L.(Ed). New Approaches for Isolation of Cryptosporidium and Giardia. American Water Works Association, 2000.

CORREA, A. C. F. et al. Perspectiva De Alteração De Coagulante Para Estação De Tratamento De Água Operando Com Sobrecarga. 23 Congresso Brasileiro de Engenharia Sanitária e Ambiental, 2005. Anais Eletrônicos: I-137. Campo Grande - MS.

DAI, X.; BOLL, J. Settling velocity of Cryptosporidium parvum and Giardia lamblia. Water Research, v. 40, n. 6, p. 1321-1325, Mar 2006. ISSN 0043-1354.

DALSASSO, R. L.; SENZ M. L. Filtração Direta com Pré-floculação e Coagulação com Sulfato de Alumínio e Hidroxicloreto ee Alumínio: Estudo com Água de Manancial Eutrofizado. Engenharia Sanitária e Ambiental. Vol 11, n³- jul/set 2006, 241-249

DALY, E. R.; ROY, S. J.; BLANEY, D. D.; MANNING; J. S.; HILL, V. R.; XIAO, L.; STULL, J. W. Outbreak of Giardiasis associated with a community drinking-water source. Epidemiology and Infection, v. 138, n. 4, p. 491-500, Apr 2010. ISSN 0950-2688.

DI BERNARDO, L. (Coord.). Tratamento de água para abastecimento por filtração direta. PROSAB 3. Rio de Janeiro: ABES, RiMA, 2003, 498 p.

DI BERNARDO, A.; Desempenho de sistemas de dupla filtração no tratamento de água com turbidez elevada. Tese (Doutorado) - Escola de Engenharia - Universidade de São Paulo, 2004.

DI BERNARDO, L.; SABOGAL PAZ, L. P. (2008). Seleção de Tecnologias de Tratamento de Água. Editora LDiBe. v 1 e v.2. p.1560.

DI BERNARDO, L.; DANTAS, A. D. B.; VOLTAN, P. E. N. (2011). Tratabilidade de Água e dos Resíduos gerados em Estações de Tratamento de Água. Editora LDiBe. 
DIAS, G. M. F. et al. Giardia spp. e Cryptosporidium spp. em água de manancial superficial de abastecimento contaminada por dejetos humano e animal. Arquivo Brasileiro de Medicina Veterinária e Zootecnia, v. 60, n. 6, p. 1291, ISSN 01020935.

DAI, X.; BOLL, J. Settling velocity of Cryptosporidium parvum and Giardia lamblia. Water research, v. 40, n. 6, p. 1321-1325, 2006.

DE JULIO, M. et al. Avaliação da Remoção de Cianobactérias e Saxitoxinas da Água Bruta Afluente à ETA Pitangui de Ponta Grossa/PR, Utilizando os Diagramas de Coagulação para o Sulfato de Alumínio e PAC. $25^{\circ}$ Congresso Brasileiro de Engenharia Sanitária e Ambiental. Anais Eletrônicos: I-071. Recife - PE. Brasil. 2009.

DE JULIO, M.; FIORAVANTE, D. A.; GRAHAM, N. J. D. Remoção de cianobactérias de água proveniente de manancial brasileiro eutrofizado, utilizando os diagramas de coagulação para o sulfato de alumínio e PAC. Engenharia Civil UM, nº 37, 2010.

DUGAN, N.R. et al. Controlling Cryptosporidium oocysts using conventional filtration. Journal of American Water Works Association, 93 (2001), pp. 64-77

EDZWALD, J. K. Dissolved air flotation and me. Water Research, v. 44, n. 7, p. 2077-2106, Apr 2010. ISSN 0043-1354.

EMELKO, M. B. Removal of viable and inactivated Cryptosporidium by dual- and tri-media filtration. Water Research, v. 37, n. 12, p. 2998-3008, Jul 2003. ISSN 0043-1354.

FENG, Y.; XIAO, L. Zoonotic Potential and Molecular Epidemiology of Giardia Species and Giardiasis. Clinical Microbiology Reviews, v. 24, n. 1, p. 110-+, Jan 2011. ISSN 0893-8512; 1098-6618.

FERRARI, T. N; DE JULIO, M.; DE JULIO T., S. Emprego do Sulfato de Alumínio e do Cloreto de Polialumínio em estudos de Tratabilidade da Água que abastece o Município de São José dos Campos-Sp. Engenharia Ambiental - Espírito Santo do Pinhal, v. 8, n. 4, p. $118-137$, out./dez. 2011

FERREIRA FILHO, S. S.; WAELKENS, B. E. Aspectos químicos do cloreto de polialumínio como coagulante no tratamento de águas de abastecimento. $25^{\circ}$ Congresso Brasileiro de Engenharia Sanitária e Ambiental. Anais Eletrônicos: I-073. Recife - PE. Brasil, 2009a. 
FERREIRA FILHO, S. S.; WAELKENS, B. E. Minimização da Produção de Lodo no Tratamento de Águas de Abastecimento Mediante uso de Cloreto de Polialumínio e sua Disposição em Estações de Tratamento de Esgotos. Engenharia Sanitária e Ambiental v.14 n.3 |ul/set 2009b 317-326.

FERNANDES, G. N. M.; GINORIS, Y. P., RIOS, R. H. T., \& BRANDÃO, C. C. S. The influence of coagulation $\mathrm{pH}$ and aluminum sulphate dose in removal of Cryptosporidium oocysts by down flow direct filtration. Engenharia Sanitária e Ambiental, v. 15, n. 4, p. 375-384, Oct-Dec 2010. ISSN 1413-4152.

FRANCO, R. M. B., CORDEIRO, N. da S. Giardiose e criptosporidiose em creches no município de Campinas, SP. Revista da Sociedade Brasileira de Medicina Tropical 1996;29:585-591

FRANCO,R.M.B.; ROCHA-EBERHARDT, R.; CANTUSIO NETO, R. Occurrence of Cryptosporidium oocysts and Giardia cysts in raw water from the Atibaia river, Campinas, Brazil. Revista do Instituto de Medicina Tropical de São Paulo. Vol. 43, n.2, p.109-111, 2001.

FRANCO, R. M. B. Protozoários de veiculação hídrica: relevância em saúde pública. Revista Panamericana de Infectologia. (4):36-43; 2007

FRANCO, R. M. B.; BRANCO N.; LEAL, D. A. G. Parasitologia Ambiental: Métodos de Concentração e Detecção de Cryptosporidium spp. e Giardia spp em Amostras de Água. Revista de Patologia Tropical. Vol. 41 (2): 119-135. abr.-jun. 2012

FRANCO, R. M. B. et al. Avaliação da performance de metodologias de detecção de Cryptosporidium spp. e Giardia spp. em água destinada ao consumo humano, para o atendimento às demandas da Vigilância em Saúde Ambiental no Brasil. Epidemiologia e Serviços da Saúde, Brasília, 21(2):233-242, abr-jun 2012

GARCIA, L. S.; SHUM, A. C.; BRUCKNER, D. A. Evaluation of a new monoclonalantibody combination reagent for direct fluorescence detection of Giardia cysts and Cryptosporidium oocysts in human fecal specimens. Journal of Clinical Microbiology, v. 30, n. 12, p. 3255-3257, Dec 1992. ISSN 0095-1137. 
GOMES, L. N. G.; AZEVEDO, S. M. F. O. Técnicas de Manejo e Pré-tratamento no Manancial in PÁDUA, V. L. (coord.) Contribuição ao estudo da remoção de cianobactérias e microcontaminantes orgânicos por meio de técnicas de tratamento de água para o consumo humano. Rio de Janeiro: ABES, 2006

GONÇALVES, E. M. N.et al. Multilocus genotyping of Cryptosporidium hominis associated with diarrhea outbreak in a daycare unit in São Paulo. Clinics [online] 2006;61:119-126.

GRIMASON, A. M. et al. Application of DAPI and immunofluorescence for enhanced identification of Cryptosporidium spp oocysts in water samples. Water Research, v. 28, n. 3, p. 733-736, 1994.

GRIFFITH, J. J. A disciplina do pensamento sistêmico. Viçosa, MG: Universidade Federal de Viçosa, Departamento de Engenharia Florestal, 2008.

GUERDEN, T.; OLSON, M. Giardia in Pets and Farm Animals, and Their Zoonotic Potential in Humans in: LUJÀN, H. D.; SVÄRD, S. editors, Giardia: A model Organism. Springer, 2011.

HACHICH, E. M. et al. Giardia and Cryptosporidium in source waters of Sao Paulo State, Brazil. Water Science and Technology, v. 50, n. 1, 2004. ISSN 0273-1223.

HIJNEN, W. A. M. et al. GAC adsorption filters as barriers for viruses, bacteria and protozoan (oo)cysts in water treatment. Water Research, v. 44, n. 4, p. 1224-1234, Feb 2010. ISSN 0043-1354.

HSU, B. M.; HUANG, C. P.; PAN, J. R. Filtration behaviors of Giardia and Cryptosporidium - Ionic strength and pH effects. Water Research, v. 35, n. 16, p. 3777-3782, Nov 2001. ISSN 0043-1354.

HSU, B. M.; HUANG, C. P. Influence of ionic strength and pH on hydrophobicity and zeta potential of Giardia and Cryptosporidium. Colloids and Surfaces a-Physicochemical and Engineering Aspects, v. 201, n. 1-3, p. 201-206, Mar 5 2002. ISSN 0927-7757.

HSU, B.; YEH, H. Removal of Giardia and Cryptosporidium in drinking water treatment: a pilot-scale study. Water Research, v. 37, n. 5, p. 1111-1117, 2003 
KORICH, D. G. et al. Effects of ozone, chlorine dioxide, chlorine, and monochloramine on Cryptosporidium parvum oocyst viability. Applied and Environmental Microbiology, v. 56, n. 5 , p. 1423-1428, 1990.

LeCheVhllier, M., L.; AU, K. Water Treatment and Pathogen Control: Process. IWA publishing, 2004.

LIBÂNIO, M. Fundamentos de Qualidade e Tratamento de Água. Ed. Átomo. Belo Horizonte/MG, 2008.

LINDQUIST, H. D. Criteria for evaluation of proposed protozoan detection methods. Journal of Microbiological Methods, 37(1), 33-43, 1999.

LOPES, F. M. F. et al.. Comparação da Flotação por ar Dissolvido e Sedimentação no Tratamento de Água Utilizando Policloreto de Alumínio. 25 Congresso Brasileiro de Engenharia Sanitária e Ambiental. Anais Eletrônicos: I-111. Recife - PE. Brasil, 2009.

MACHADO, E. C. L. et al. Ocorrência de oocistos de Cryptosporidium spp. em águas superficiais na região metropolitana de Recife-PE. Arquivo Brasileiro de Medicina Veterinária e Zootecnia, v. 61, n. 6, p. 1459-1462, 2009.

MACKENZIE, W. R. et al. A massive outbreak in milwaukee of Cryptosporidium infection transmitted through the public water-supply. New England Journal of Medicine, v. 331, n. 3, p. 161-167, Jul 1994. ISSN 0028-4793.

MARTINS, F. C. Investigação da aplicabilidade da turbidez e de bactérias esporogênicas aeróbias na avaliação da remoção de oocistos de Cryptosporidium spp. e cistos de Giardia spp. em sistemas de abastecimento de água: Uma abordagem de avaliação de risco. Dissertação (mestrado) - Universidade Federal de Minas Gerais, Escola de Engenharia, 2012.

MEDEIROS, R. C. Comparação da resistência de protozoários patogênicos Giardia spp. e Cryptosporidium spp. e de microrganismos indicadores à desinfecção seqüencial clororadiação ultravioleta e ozônio-radiação ultravioleta. Dissertação (mestrado). Escola de Engenharia de São Carlos. Universidade de São Paul, 2010. 
MEDEIROS, R. C. Avaliação da remoção de Giardia spp. e Cryptosporidium spp. em processos de tratamento de esgoto sanitário. Tese (doutorado) - Escola de Engenharia de São Carlos, Universidade de São Paulo, 2013.

MONIS, P.; KING, B.; KEEGAN, A. Removal and Inactivation of Cryptosporidium from Water in CACCIO, S. M.; WIDMER, G. (editors). Cryptosporidium: Parasite and Disease, Springer, 2014.

ONGERTH, J. E.; SAAED; F. M.A. Distribution of Cryptosporidium oocysts and Giardia cysts in water above and below the normal limit of detection. Parasitology Research, v. 112, n. 2, p. 467-471, 2013.

PAPINEAU, I. et al..Impact of Media Aging on the Removal of Cryptosporidium in Granular Media Filters. Journal of Environmental Engineering-Asce, v. 139, n. 5, p. 603-611, May 2013. ISSN 0733-9372.

PAVAnelli, G. Eficiência de Diferentes Tipos de Coagulantes na Coagulação, Floculação e Sedimentação de Água com Cor ou Turbidez Elevada. Dissertação (mestrado). Escola de Engenharia de São Carlos. Universidade de São Paulo - EESC/USP. Brasil, 2001.

PLUTZER, J.; ONGERTH, J.; KARANIS, P. Giardia taxonomy, phylogeny and epidemiology: Facts and open questions. International Journal of Hygiene and Environmental Health, v. 213, n. 5, p. 321-333, 2010.

RAZZOLINI, M.; DA SILVA SANTOS, T.; BASTOS, V. Detection of Giardia and Cryptosporidium cysts/oocysts in watersheds and drinking water sources in Brazil urban areas. Journal of Water and Health, v. 8, n. 2, p. 399-404, 2010.

RAN, Z. et al. Inactivation of Cryptosporidium by ozone and cell ultrastructures. Journal of Environmental Sciences, 22(12), 1954-1959, 2010.

RAZZOLINI, M. T. et al. Risk of Giardia infection for drinking water and bathing in a periurban area in Sao Paulo, Brazil. International Journal of Environmental Health Research, v. 21, n. 3, p. 222-234, 2011 2011. ISSN 0960-3123. 
RYAN, U.; XIAO, L. Taxonomy and Molecular Taxonomy in: CACCIO, S. M.; WIDMER, G. (editors). Cryptosporidium: Parasite and Disease. Springer, 2014.

SANTOS, L.U. Ocorrência de oocistos de Cryptosporidium spp. e cistos de Giardia spp. em uma Estação de Tratamento de Esgoto: avaliação das eficiências do processo de lodo ativado na remoção e de desinfecção por luz ultravioleta na inativação desses patógenos.132p. Tese (Doutorado). Instituto de Biologia - Universidade Estadual de Campinas - Unicamp - SP, 2007.

SATO, M. I. Z. et al. Assessing the infection risk of Giardia and Cryptosporidium in public drinking water delivered by surface water systems in Sao Paulo State, Brazil. Science of the Total Environment, v. 442, p. 389-396, Jan 2013. ISSN 0048-9697.

SHEPHERD, K. M.; WYN-JONES, A. P. An evaluation of methods for the simultaneous detection of Cryptosporidium oocysts and Giardia cysts from water. Applied and Environmental Microbiology, v. 62, n. 4, p. 1317-1322, 1996.

SILVA, C. F. Remoção de oocistos e de indicadores físicos de Cryptosporidium parvum em águas de abastecimento por meio as decantação em escala piloto. Dissertação de mestrado Escola de Engenharia- Universidade Federal de Minas Gerais, 2008.

ŠLAPETA, J. Cryptosporidiosis and Cryptosporidium species in animals and humans: A thirty colour rainbow?. International Journal for Parasitology, v. 43, n. 12, p. 957-970, 2013.

SMITH, H. V.; GRIMASON, A. M. Giardia and Cryptosporidium in water and wastewater in: MARA, D.; HORAN, N. The Handbook of Water and Wastewater Microbiology, 2003. ISBN 0-12-470100-0.

STATES, S.; TOMKO, R. J. Enhanced coagulation and removal of Cryptosporidium. Journal American Water Works Association, v. 94, n. 11, p. 67-77, Nov 2002. ISSN 0003$150 X$.

TOZE, S. PCR and the detection of microbial pathogens in water and wastewater. Water Research, v. 33, n. 17, p. 3545-3556, 1999. 
TUFENKJI, N. et al. Transport of Cryptosporidium oocysts in porous media: Role of straining and physicochemical filtration. Environmental Science \& Technology, v. 38, n. 22, p. 5932-5938, 2004.

TUFENKJI, Nathalie et al. Multi-scale Cryptosporidium sand interactions in water treatment.Water Research, v. 40, n. 18, p. 3315-3331, 2006.

UNITED STATES ENVIRONMENTAL PROTECTION AGENCY (USEPA). Method 1623.1 Cryptosporidium and Giardia in Water by Filtration/IMS/FA. Office of Water (MS-140) EPA 816 -R-12-001. January 2012

UNITED STATES ENVIRONMENTAL PROTECTION AGENCY (USEPA). Wastewater Technology Fact Sheet - Ozone Disinfection. EPA 832-F-99-063. Office of Water, Washington, DC, 1999.

VESEY, G. et al. A new method for the concentration of Cryptosporidium oocysts from water. Journal of Applied Bacteriology, v. 75, n. 1, p. 82-86, 1993.

WIDERSTROM, M. et al. Large Outbreak of Cryptosporidium hominis Infection Transmitted through the Public Water Supply, Sweden. Emerging Infectious Diseases, v. 20, n. 4, p. 581 589, Apr 2014. ISSN 1080-6040; 1080-6059

WIDMER, G. et al. Structural and Biochemical Alterations in Giardia lamblia cysts Exposed to Ozone. Journal of Parasitology. 88(6), 2002, pp. 1100-1106.

WHO World Health Organization. Guidelines for drinking-water quality - $4^{\text {th }}$ ed. 2011

WOHLSEN, T. et al. The efficiency of ozonated water from a water treatment plant to inactivate Cryptosporidium oocysts during two seasonal temperatures. Journal of Water and Health, 5(3), 433-440, 2007.

XAGORARAKI, I.; HARRINGTON, G. W. Zeta potential, dissolved organic carbon, and removal of Cryptosporidium oocysts by coagulation and sedimentation. Journal of Environmental Engineering-Asce, v. 130, n. 12, p. 1424-1432, Dec 2004. ISSN 0733-9372.

XIAO, L. Molecular epidemiology of cryptosporidiosis: An update. Experimental Parasitology, v. 124, n. 1, p. 80-89, Jan 2010. ISSN 0014-4894. 
XIAO, L.; FAYER, R. Molecular characterisation of species and genotypes of Cryptosporidium and Giardia and assessment of zoonotic transmission. International Journal for Parasitology, v. 38, n. 11, p. 1239-1255, Sep 2008. ISSN 0020-7519; 18790135 . 
ANEXO 
WATERBORNE ${ }^{\mathrm{TM}}$, INC.

Clinical and Fnyironmental Parasitology Products * 6045 Hurst Street, New Orleans, 1 A 70118 USA

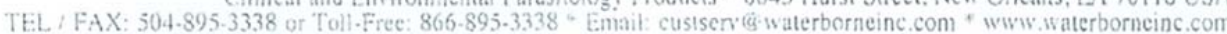

\section{Product Specification and Analysis Report Cryptosporidium parvum}

Product: Suspension of Oocysts of Cryptosporidium parvum, Iowa isolate, for use in research.

Source of the oocysts: Experimentally infected calves

Species/genus identification method(s): Direct immunofluorescence microscopy with genus-specific monoclonal antibodies; also phase microscopy.

\begin{tabular}{|l|l|}
\hline Lot t: $8-13$ & Date shed: $5 / 3 / 13$ \\
\hline Totai number of oocysts provided: $1 \times 10^{6}$ & Date purified: $5 / 5 / 13$ \\
\hline
\end{tabular}

Total volume:

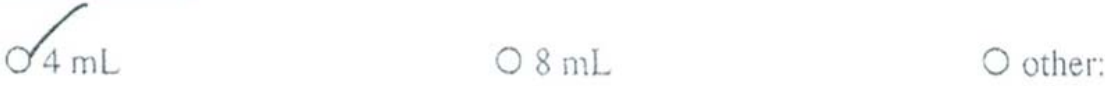

Stoxkge solution:

OPBS with penicillin, streptomycin, gentamicin, Amphotericin B. $0.01 \%$ Tween 20

. $5 \%$ Formalin/PBS \& $0.01 \%$ Tween 20

O other:

Purification method(s): Oocysts are purified from feces by sucrose and Percoll density gradient centrifugation, after initial extraction of feces with diethyl ether.

Quantitation Method: Neubauer hemacytometer counting, using red blood cell method.

Storage Conditions: 4 to 6 degrees Celcius (i.e. refrigerator temperature)

Expiration date: The shelf life of live C. parvum oocysts is guaranteed up to 2 months after the date of shipment; however, viability and useful life of oocysts for research may continue for a much longer period provided oocysts are stored at refrigerator ( $4.8 \mathrm{deg}$. C) temperatures in the presence of antibiotics, including Amphotericin B as fungicide ( $0.25 \mathrm{ug}$ per $\mathrm{ml})$.

Formalinized oocysts are guaranteed for 6 months after date of receipt.

The organisms enclosed in this package are infectious to humans and animals by oral ingestion. The safe handling and disposal of the contents of this package are the responsibility of the recipient. 
APÊNDICE 


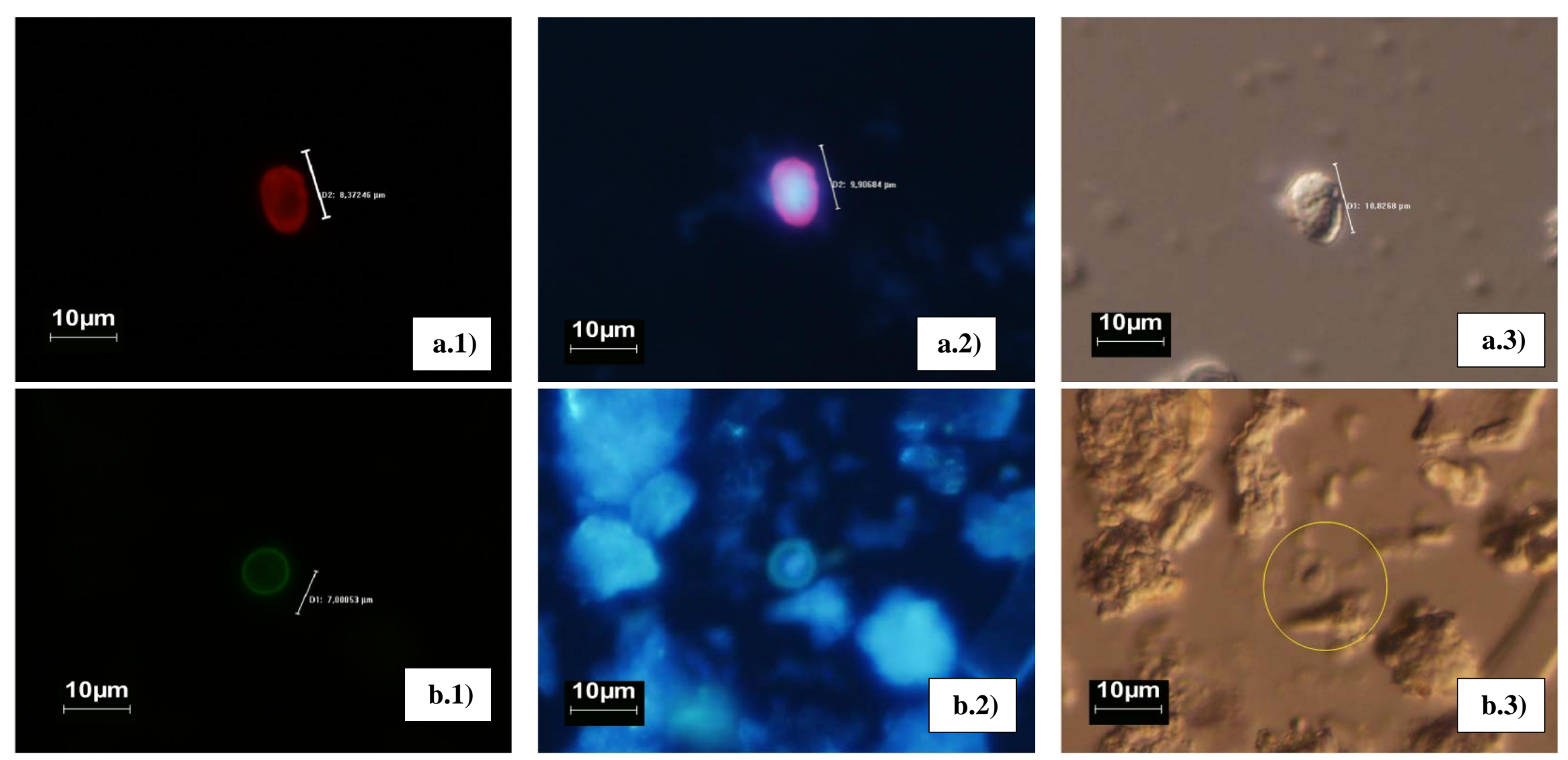

Figura 0.1- Elementos de difícil interpretação; a) objeto semelhante ao cisto Giardia spp., apresentou coloração vermelha na microscopia de fluorescência em FITC, aumento de 400x; a.1) imagem de microscopia em fluorescência FITC, a.2) imagem de microscopia em fluorescência DAPI, a.3) imagem em microscopia DIC; b) objeto com formato idêntico a um oocisto de Cryptosporidium spp., tamanho maior que a referência do método USEPA 1623.1, aumento de 400x; b.1) imagem de microscopia em fluorescência FITC, b.2) imagem de microscopia em fluorescência DAPI, b.3) imagem em microscopia DIC 

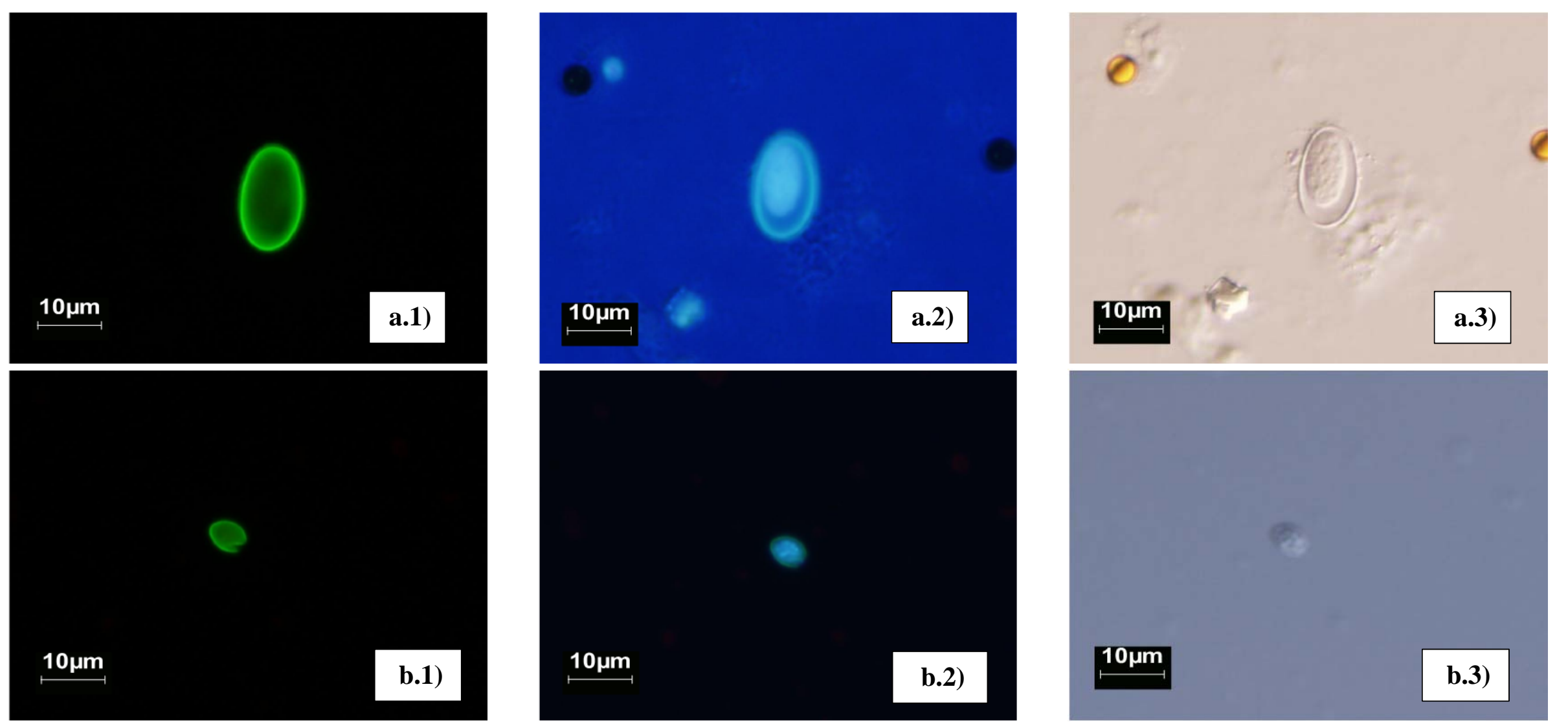

Figura 0.2- Imagens típicas visualizadas nas análises de microscopia em testes com purificação por IMS a) cisto de Giardia spp. aumento de 400x, a.1) visualização em fluorescência FITC, a.2) visualização em fluorescência DAPI, a.3) visualização em DIC; b) oocisto de Cryptosporidium spp., b.1) visualização em fluorescência FITC, b.2) visualização em fluorescência DAPI, b.3) visualização em DIC 

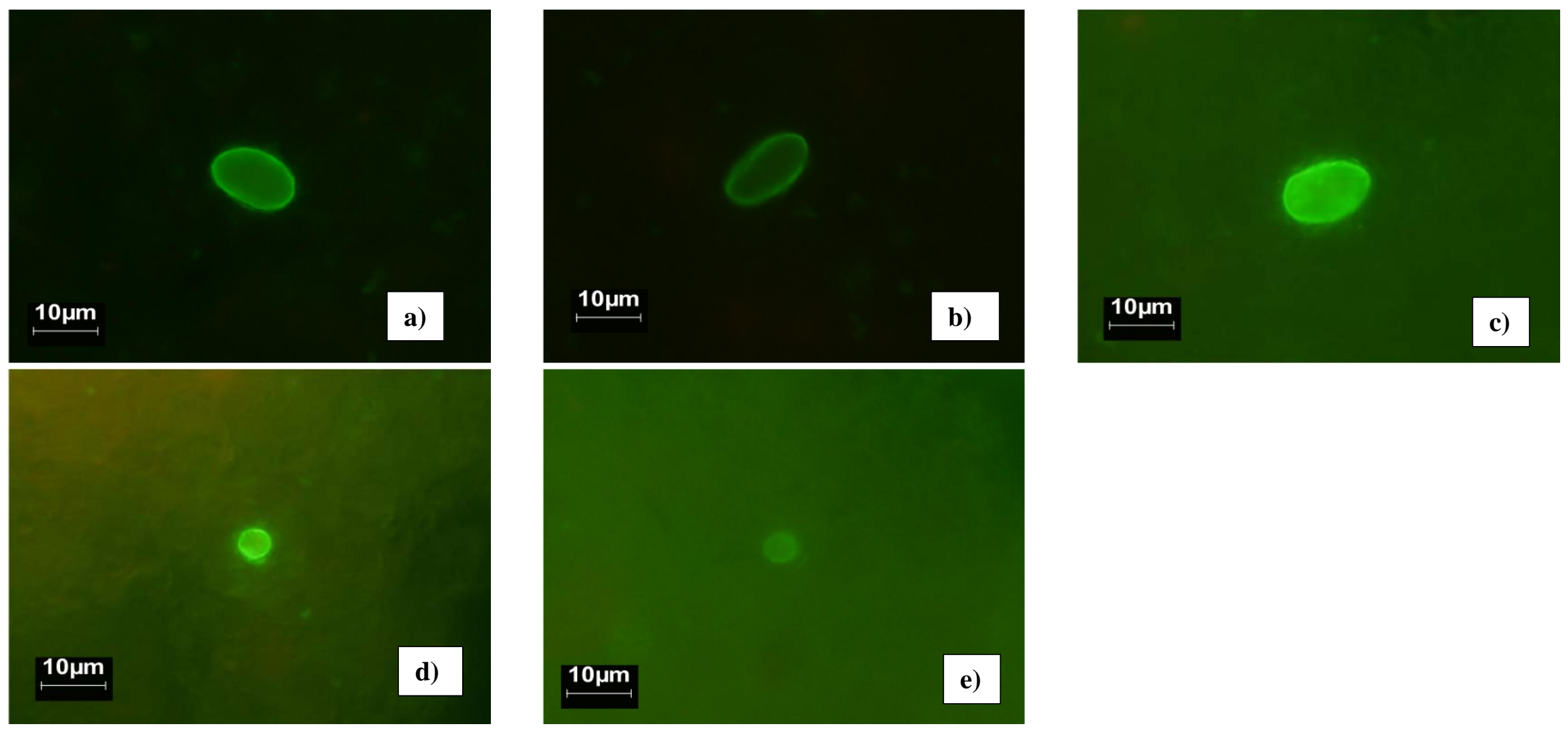

Figura 0.3- Imagens típicas da visualização de (oo)cistos na microscopia de FITC, quando não ocorreu purificação por IMS; a), b,) e c) se referem aos cistos de Giardia spp. visualizados em amostras de água bruta; d) e e) se referem à oocistos de Cryptosporidium spp. visualizados em amostras de água bruta. 

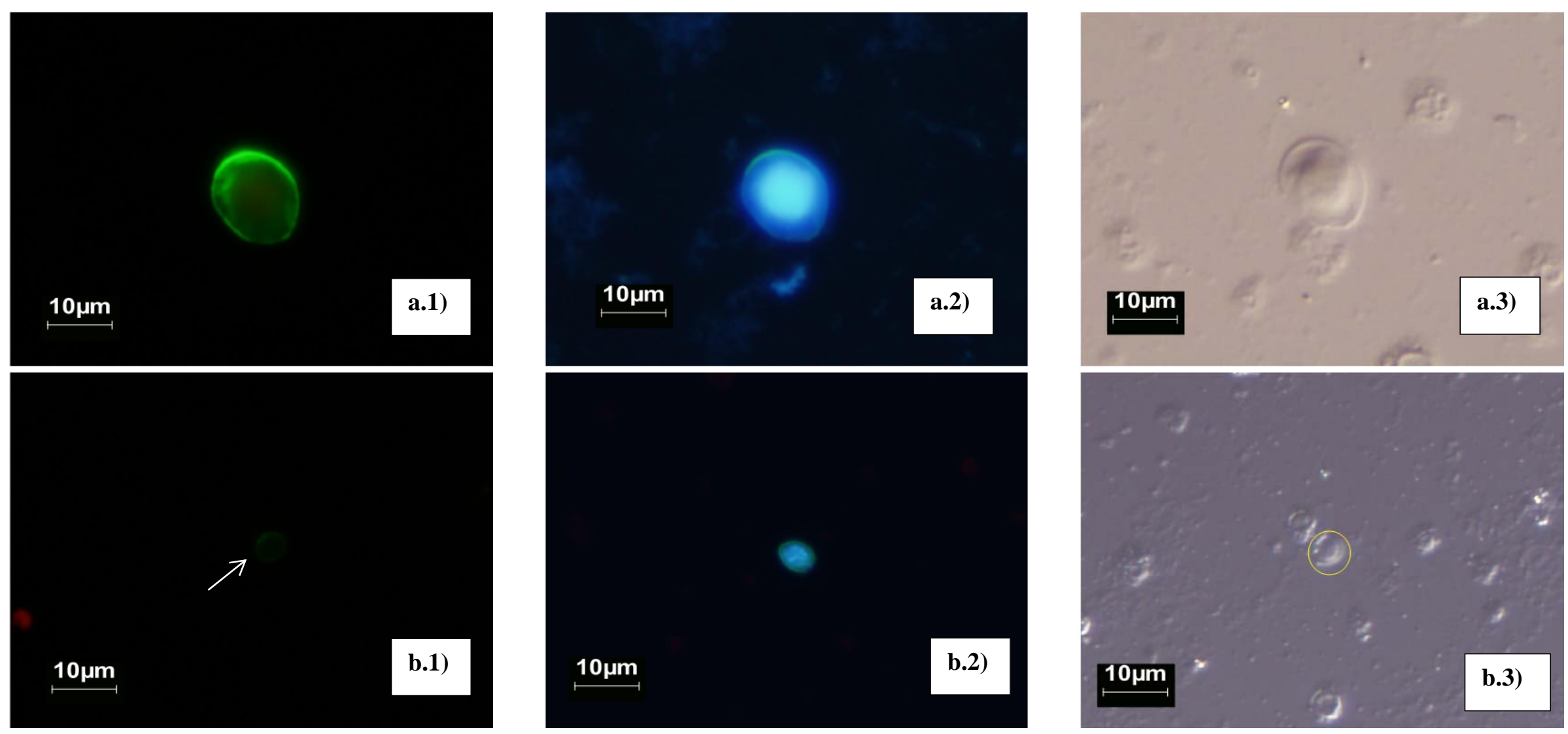

Figura 0.4- Imagens de microscopia de (oo)cistos visualizados na água filtrada quando se utilizou a purificação por IMS; a) cisto de Giardia spp. em aumento de 400x a.1) microscopia de fluorescência em FITC, a.2) microscopia de fluorescência em DAPI, a.3) microscopia DIC; b) oocisto de Cryptosporidium spp. b.1) microscopia de fluorescência em DAPI, b.2) microscopia de fluorescência em DAPI, b.3) microscopia DIC. 